Joanna Wawrzyniak

\title{
Veterans, Victims, and Memory
}

The Politics of the Second World War in Communist Poland

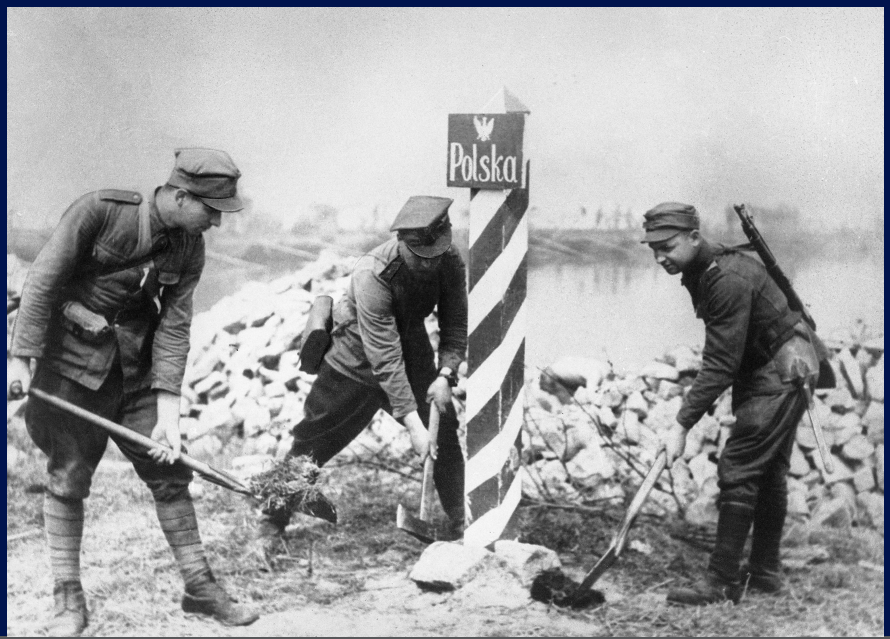




\section{Joanna Wawrzyniak}

\section{Veterans, Victims, and Memory}

In the vast literature on how the Second World War has been remembered in Europe, research into what happened in communist Poland, a country most affected by the war, is surprisingly scarce. The long gestation of Polish narratives of heroism and sacrifice, explored in this book, might help to understand why the country still finds itself in a 'mnemonic standoff' with Western Europe, which tends to favour imagining the war in a civil, post-Holocaust, human rights-oriented way. The specific focus of this book is the organized movement of war veterans and former prisoners of Nazi camps from the 1940s until the end of the 1960 s, when the core narratives of war became well established.

\author{
The Author \\ Joanna Wawrzyniak is Deputy Director of \\ the Institute of Sociology at the University \\ of Warsaw, where she also heads the Social \\ Memory Laboratory. She has published \\ extensively on the relationship between \\ history and memory in Poland, the uses \\ of oral history, and the current state \\ of memory studies in Central-Eastern \\ Europe. Recently she was a visiting \\ fellow at Freiburg Institute for Advanced \\ Studies and at Imre Kertész Kolleg in Jena \\ (Germany).
}


Veterans, Victims, and Memory

Joanna Wawrzyniak - 978-3-653-99681-4

Downloaded from PubFactory at 01/11/2019 11:05:35AM

via free access 


\section{STUDIES IN CONTEMPORARY HISTORY}

Edited by Dariusz Stola / Machteld Venken

VOLUME 4

$\frac{\text { PETER LANG }}{\text { E D I T I O N }}$

Joanna Wawrzyniak - 978-3-653-99681-4

Downloaded from PubFactory at 01/11/2019 11:05:35AM

via free access 
Joanna Wawrzyniak

\section{Veterans, Victims, and Memory}

The Politics of the Second World War in Communist Poland

Translated by Simon Lewis

PETER LANG 


\title{
Bibliographic Information published by the Deutsche Nationalbibliothek
}

The Deutsche Nationalbibliothek lists this publication in the Deutsche Nationalbibliografie; detailed bibliographic data is available in the internet at http://dnb.d-nb.de.

The publication is founded by Ministry of Science and Higher Education of the Republic of Poland as part of the National Programme for the Development of the Humanities. This publication reflects the views only of the authors, and the Ministry can not be held responsible for any use which may be made of the information contained herein.

\section{NARODOWY PROGRAM
ROZWOJU HUMANISTYK}

Cover image: Marking of the new Polish border on the Oder (Odra). 1945.

Photo credit: unknown, National Digital Archives in Poland.

\author{
ISSN 2364-2874 \\ ISBN 978-3-631-64049-4 (Print) \\ E-ISBN 978-3-653-02441-8 (E-Book) \\ DOI 10.3726/978-3-653-02441-8 \\ (c) Peter Lang $\mathrm{GmbH}$ \\ Internationaler Verlag der Wissenschaften \\ Frankfurt am Main 2015 \\ All rights reserved.
}

Peter Lang Edition is an Imprint of Peter Lang GmbH.

Peter Lang - Frankfurt am Main · Bern · Bruxelles · New York .

Oxford · Warszawa $\cdot$ Wien

All parts of this publication are protected by copyright. Any utilisation outside the strict limits of the copyright law, without the permission of the publisher, is forbidden and liable to prosecution. This applies in particular to reproductions, translations, microfilming, and storage and processing in electronic retrieval systems.

This publication has been peer reviewed.

www.peterlang.com 


\section{Table of Contents}

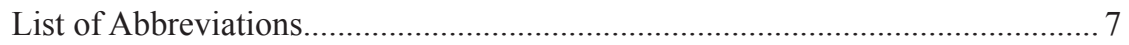

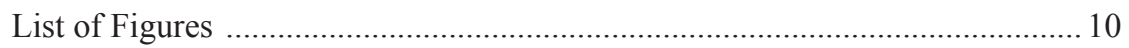

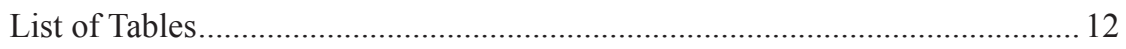

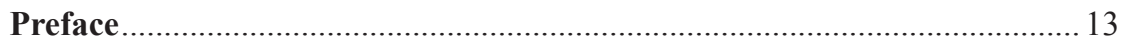

Chapter 1: Communism, Myth and Memory ............................................. 19

Collective Memory, Memory Groups and Myths of War under Communism ... 19

Agents: Veterans, Victims and the Nation State …........................................... 26

Structures: Organizations in the Communist System ........................................ 34

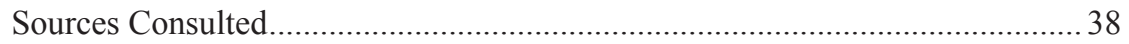

Chapter 2: The Communist Post-war: Organizing Life and Memory ........ 43

Challenges of Demobilization........................................................................ 43

Communist Legislation and the ex-Combatants and Prisoners, 1945-48:

A View From Above ................................................................................... 49

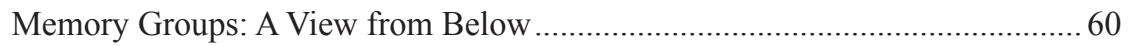

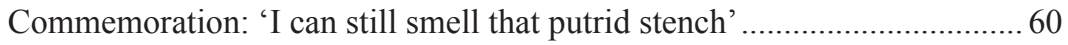

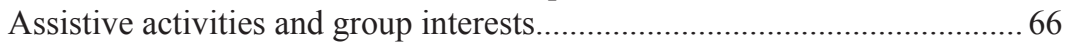

'The Soil Has Been Tilled': Towards the Unification of Memory Groups......... 77

Chapter 3: The Myth of Victory over Fascism (1949-55) ............................ 85

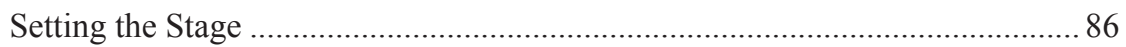

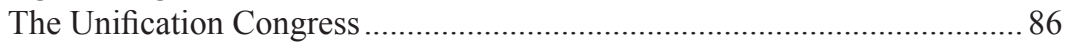

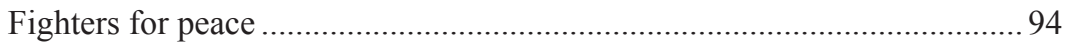

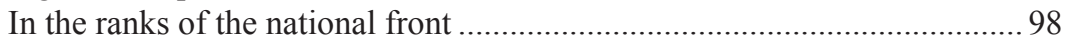

Sites of Memory and the Myth of Victory …………..................................... 100

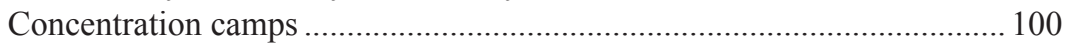

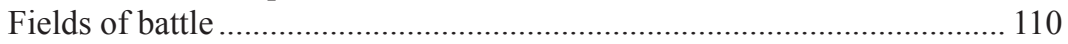

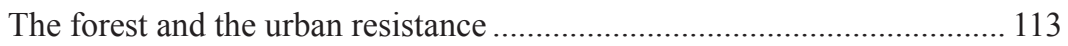

Behind the Scenes: Organization as Illusion ...................................................... 117

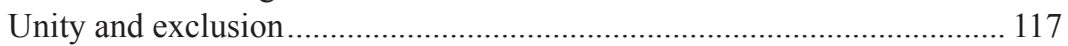

'We have been unable to plough this fallow field' ...................................... 122

The withdrawal of patronage and awards.................................................. 125 
Chapter 4: The Myth of Unity (1956-59).................................................... 135

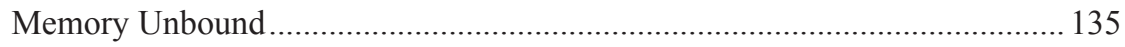

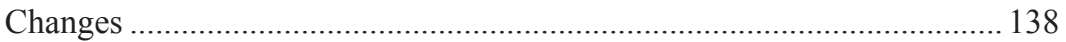

'They gather almost every day and muck-rake in the past'......................... 142

Against the monopoly of memory ............................................................. 145

ZBoWiD in the provinces: the case of Lublin region................................. 149

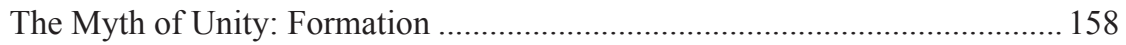

The 'family of combatants' and criteria for verification ............................. 158

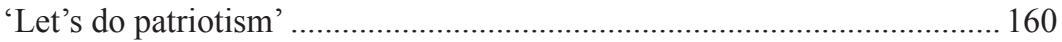

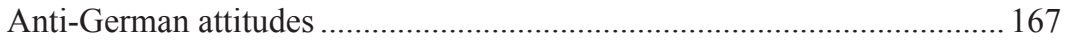

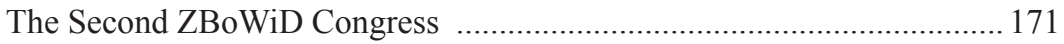

Chapter 5: The Myth of Innocence (1960-69).............................................. 177

Clientelism: 'We Have Been Able to Arrange It'............................................... 177

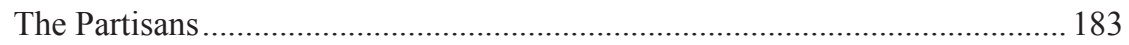

'Only ZBoWiD can speak in the name of the Home Army tradition'........ 186

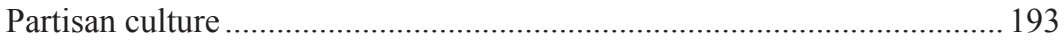

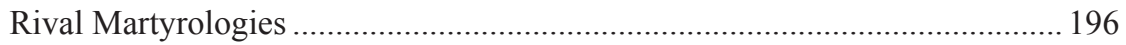

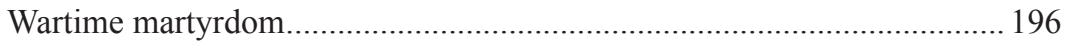

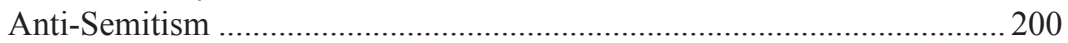

The innocent Poles and the ungrateful Jews.............................................. 203

Afterword: The Long Shadow of the Communist Politics of Memory ...... 213

Polish War Memory in Comparative Context............................................... 214

Communist Narratives: between Persistence and Change ............................... 223

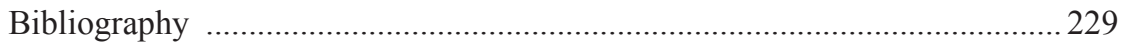

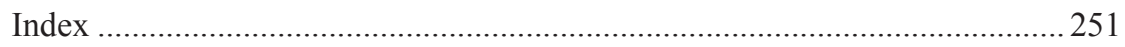




\section{List of Abbreviations}

AAN

AIPN

AK

AL

AZGZKRPiBWP

Central Archives of Modern Records (Archiwum Akt Nowych)

Archives of the Institute of National Remembrance (Archiwum Instytutu Pamięci Narodowej)

Home Army (Armia Krajowa)

People's Army (Armia Ludowa)

Archives of Executive Board of the Union of Veterans of the Republic of Poland and Former Political Prisoners (Archiwum Zarzadu Głównego Związu Kombatantów Rzeczypospolitej Polskiej i Byłych Więźniów Politycznych)

Á̇IH

Archives of the Jewish Historical Institute (Archiwum Żydowskiego Instytutu Historycznego)

BCh

Peasants' Battalions (Bataliony Chłopskie)

CAW

Central Military Archives (Centralne Archiwum Wojskowe)

Dz.U. Journal of Laws of the Republic of Poland (Dziennik Ustaw)

EU European Union

FBI Federal Bureau of Investigation

FIAPP

FILDIR International Federation of Former Political Prisoners (Fédération Internationale des Anciens Prisonniers Politiques)

FIR

FMAC

FRG

GDR

GL

GUS

IAC

IPN

KC PPR

KC PZPR
Free International Federation of Deportees and Internees of the Resistance (Fédération Internationale Libre des Déportés et Internés de la Résistance) International Federation of Resistance Fighters (Fédération Internationale des Résistants)

World Federation of Former Combatants (Fédération Mondiale des Anciens Combattants)

Federal Republic of Germany

German Democratic Republic

People's Guard (Gwardia Ludowa)

Central Statistical Office of Poland (Gtówny Urząd Statystyczny)

International Auschwitz Committee

Institute of National Remembrance (Instytut Pamięci Narodowej)

Central Committee of the Polish Workers' Party (Komitet Centralny Polskiej Partii Robotniczej)

Central Committee of the Polish United Workers' Party (Komitet Centralny Polskiej Zjednoczonej Partii Robotniczej) 
KdAW

KPD

KRN

MO

MSW

NKVD

NSZ

OSA

PGR

PKWN

PPR

PPS

PRL

PSL

PZbWP

PZPR

SB

SBNORJ

SED

SKVV

UB

UN

UNRRA

UPA

USA

USRR

VVN

WiN

ZBoWiD

Committee of Anti-fascist Resistance Fighters (Komitee der antifaschistischen Widerstandskämpfer)

German Communist Party (Kommunistische Partei Deutschlands)

Homeland National Council (Krajowa Rada Narodowa)

Civic Militia (Milicja Obywatelska)

Ministry of Internal Affairs (Ministerstwo Spraw Wewnętrznych)

The People's Commissariat for Internal Affairs (Narodnyy Komissariat Vnutrennikh Del)

National Armed Forces (Narodowe Sity Zbrojne)

Open Society Archives

State Agricultural Farm (Państwowe Gospodarstwo Rolne)

Polish Committee for National Liberation (Polski Komitet Wyzwolenia Narodowego)

Polish Workers' Party (Polska Partia Robotnicza)

Polish Socialist Party (Polska Partia Socjalistyczna)

Polish People's Republic (Polska Rzeczpospolita Ludowa)

Polish People's Party (Polskie Stronnictwo Ludowe)

Polish Union of Former Political Prisoners (Polski Związek bytych Więźniów Politycznych)

Polish United Workers' Party (Polska Zjednoczona Partia Robotnicza)

Security Service (Stużba Bezpieczeństwa)

Union of Fighters in the War of National Liberation in Yugoslavia (Savez Boraca u Narodnooslobodilačkom ratu u Jugoslaviji)

Socialist Unity Party of Germany (Sozialistische Einheitspartei Deutschlands)

Soviet Committee of War Veterans (Sovetskii Komitet Veteranov Voiny)

Public Security Service (Urząd Bezpieczeństwa)

United Nations

United Nations Relief and Rehabilitation Administration

Ukrainian Insurgent Army (Ukrayins 'ka Povstans 'ka Armiya)

United States of America

Union of Soviet Socialist Republics

Association of Persons Persecuted by the Nazi Regime (Vereinigung der Verfolgten des Naziregimes)

Freedom and Independence (Zrzeszenie Wolność i Niezawisłość)

Union of Fighters for Freedom and Democracy (Związek Bojowników o Wolność i Demokrację) 
ZG ZBoWiD Executive Board of the Union of Fighters for Freedom and Democracy (Zarząd Główny ZBoWiD)

ZO ZBoWiD Local Board of the Union of Fighters for Freedom and Democracy (Zarzad Okręgowy ZBoWiD)

ZMP

Union of Polish Youth (Związek Młodzieży Polskiej)

ZOW

Union of Military Settlers in the Recovered Territories (Zwiazek Osadników Wojskowych na Ziemiach Odzyskanych)

ZPW

Union of Wielkopolska Insurgents of 1918-19 (Zwiazek Powstańców Wielkopolskich 1918-19)

ZUWZoNiD Union of Participants of the Armed Struggle for Independence and Democracy (Związek Uczestników Walki Zbrojnej o Niepodległość $i$ Demokracje)

ZWPŚ

Union of Veterans of the Silesian Uprisings (Związek Weteranów Powstań Śląskich)

ZWZ Union of Armed Struggle (Zwiazek Walki Zbrojnej) 


\section{List of Figures}

2.1 Map of post-war shifts of borders. Wikimedia Commons.

2.2 Poster of the Congress of ZUWZoNiD in Warsaw, 1945. National Library of Poland.

2.3 Appeal addressed to partisans, resistance members, and soldiers to join ZUWZoNiD; it offers benefits and legal assistance. National Library of Poland.

2.4 Appeal to demobilized soldiers to join ZUWZoNiD, 1947. National Library of Poland.

2.5 March organized by Polish Union of Former Political Prisoners, Krakowskie Przedmieście Street, Warsaw, March 1947. Photo by Jerzy Baranowski, National Digital Archives/Polish Press Agency.

2.6 Unveiling of the Gloria Victis Memorial dedicated to the Home Army, the second anniversary of the Warsaw Uprising, Powązki Military Cemetery, Warsaw, 1 August 1946. Photo by Jerzy Baranowski, Polish Press Agency.

2.7 Propaganda picture of a former soldier of a female brigade of Polish Armed Forces in the East ploughing the post-German territories, Platerowo, 1946. Photo by Dąbrowiecki, National Digital Archives/Polish Press Agency.

2.8 Announcements of meetings of ZUWZoNiD concerning the planned merger of veteran organizations, 1947/1948. National Library of Poland.

3.1 Ceremony at the Monument to Brotherhood in Arms, on the fourth anniversary of the liberation of Warsaw's Praga district. September, 1948, Warsaw. Photo credits unknown, Polish Press Agency.

3.2 Plan of the demonstration of support to the Unification Congress of veterans and former prisoners organizations, 31 August 1949, drawn in Department of Propaganda of KC PZPR. AAN, KC PZPR, VII, 2672, p. 10.

3.3 Decorated backdrop in the hall of the University of Technology during the Unification Congress. The two swords symbolize the victory over the Knights of the Cross in the Battle of Grunwald (1410) and, by extension, over Germany. The caption between the swords runs: 'We stand united guarding Democracy and Independence of People's Poland', Warsaw, September 1949. Photo by Wojciech Konradzki, National Digital Archives/Polish Press Agency. 
3.4 Delegates to the Unification Congress after wreath laying ceremony at the Tomb of the Unknown Soldier, 31 August 1949. Photo by Dąbrowiecki, National Digital Archives/Polish Press Agency.

3.5 Conceptualisations of ZBoWiD member's badge submitted to the design contest of 1950, illustrating the ruling ideas of the time. The explanation under the last one runs: 'The Polish sword (Polish nation) cuts the chains of fascism and capitalism thereby securing world peace.' AZGZKRPiBWP 3,7.

4.1 Notice of celebrating a Day of International Solidarity of Resistance Fighters, Sieradz, April 1957. National Library of Poland.

4.2 Notice of the opening of a travelling exhibition: 'Documents of Hitlerite Fascist Crimes'. National Library of Poland.

4.3 Second Congress of $\mathrm{ZBoWiD}$, a view of the presidium: Józef Cyrankiewicz is addressing the audience; to his right: Janusz Zarzycki. Palace of Culture and Science, Warsaw, 1959. Photo by Mariusz Szyperko, National Digital Archives/Polish Press Agency.

5.1 A head nurse with her war medals. Włościbórz, December 1969. Photo by Stefan Kraszewski, Polish Press Agency.

5.2 Typical propaganda motif spread by ZBoWiD during the millennial celebration of the Polish statehood: the caption runs: '6,028,000 murdered Poles. Murderers shall not be forgiven.' The number is somewhat overestimated and the formulation does not indicate that it contains also Jewish victims. The vengeful caption epitomizes the reaction of the party to the pastoral letter of Polish bishops to German bishops (November 1965), where they used the phrase: 'We forgive and ask for forgiveness.' National Library of Poland.

5.3 In 1968, an anniversary of liberating concentration camps was used as a propaganda opportunity to equate Zionism with fascism. Captions run: 'No more war', 'No more Auschwitz', 'Stop Zionism', 'Stop fascism'. Rzeszów, April 1968. 


\section{List of Tables}

3.1 ZBoWiD's income between 1950 and 1956 (thousands of złoty)

3.2 ZBoWiD's expenses between 1950 and 1956 (thousands of złoty)

4.1 Content of articles in Za Wolność i Lud, by theme (January 1957-September 1958)

5.1 Number of organization units and the total membership of ZBoWiD, 1959-69

5.2 Composition of county directorates (1961/62 and 1968)

5.3 Composition of county directorates according to group, Lublin and Warsaw voivodeships (1961/62 and 1965/66) 


\section{Preface}

In the half century of communist rule in Poland, public memory of the Second World War played a substantial role in the transmission and legitimization of power. At the same time, it was open to reinterpretations, both spontaneous and planned, which were the results of international changes, generational turns, and activities of memory groups. Still, in the vast literature on how the Second World War has been remembered in Europe, research into what happened in Poland, one of the countries most affected by the war, is surprisingly scarce. This book fills this gap by giving an account of the emergence of the core Polish narrative about the war out of two embodiments of memory: the communist state's revolutionary story on the one hand, and various memory groups' initiatives on the other. It argues that the official patterns of war memory, which evolved from revolutionary rhetoric towards patriotic narratives of collective heroism and sacrifice, were to a surprising extent the results of negotiation between the state and memory groups.

Important features of those patterns of heroism and sacrifice are still present in Poland. Their long gestation, explored in this book, might help to understand why the country often finds itself in a 'mnemonic standoff', to use James Werstch's term, ${ }^{1}$ with Western Europe, which tends to favour imagining the war in a civil, post-Holocaust, human rights-oriented way. The specific focus of this book is the organized movement of war veterans and former prisoners of Nazi camps from the 1940s until the end of the 1960s, when the core narrative became well established. The book tells the story of how certain social categories (including social entitlements for veterans and victims) were created or contested over the course of time.

Applying concepts from sociology and anthropology (including memory, myth and organization) to the history of veterans and victims, the book provides answers to three broad research questions. In what ways was the public memory of the Second World War shaped in communist Poland? How did the state and social groups interact in order to create this memory? And finally, what was the relationship between the memory of the war and the state's social policies? By tracing the construction of 'imagined communities' of veterans and victims of the war at a time when the communist system was being formed and consolidated, the author advances two main arguments. First, that the memory politics of the Second World War in communist Poland is best understood in terms of three principal narratives: the myth of victory against fascism, the myth of the unity

1 James V. Wertsch, ‘A Clash of Deep Memories', Profession (2008), pp. 46-53. 
of the resistance movement, and the myth of national innocence. The myth of victory was the most fundamental of these three, and it was complemented by the two other narratives in the aftermath of the 1956 Thaw as a result of limited compromise with society aimed at cementing the state's internal legitimacy. Second, it was at this time that there changed the social and political roles of the veterans and camp victims: whilst in the early post-war years they carried out largely symbolic functions, after the Thaw they came to represent group interests within the framework of a clientelistic state.

The chronological boundaries employed in this study (1945-1969) cover a specific and significant period in the evolution of political ideology in Poland: the dominant narrative changed from revolutionary internationalism to national communism. They also correspond to the years of the most fundamental changes in the development of the veterans' and victims' movement. The first postwar decade was a time when the Polish communist party gradually obtained a monopoly of power over public memory of the war. In 1949, the main collective protagonist of this book, a monopolistic union of veterans and victims of the war, the Union of Fighters for Freedom and Democracy (Zwiazek Bojowników o Wolność i Demokrację, ZBoWiD) was formed. After the era of Stalinist rule (1949-1955), the mid-1950s brought a Thaw, during which the communists underwent a major re-evaluation of their attitude towards the traditions of the inter-war Polish state, including its wartime defenders (the soldiers of the 1939 defensive war, the Home Army and the Polish Armed Forces in the West). The second half of the 1960s was both the apogee of the myth of a unified Polish resistance movement and the period when anti-Semitic tendencies featured most explicitly in the discourse of the state. In the following decades, the veterans' and victims' movement was granted more solid foundations in law. At the same time, the veterans were aging. They continued to play an important ritual role, but their presence in the corridors of power was diminishing. The role of veterans in the Solidarity movement (1980-81) was less significant than their role in the 1960s. After 1989, the memory of the Second World War was affected much more by people born after the war than by those who had actually experienced it.

The book is divided into five chapters. The introductory Chapter 1 presents the general framework of this study; it argues for a memory studies approach in analysing veterans' and victims' movements, draws attention to some features of these movements in Europe since the nineteenth century, and discusses the role of mass organizations under communism. Chapter 2 shows that in the first years after the war the activity of Polish veterans and former political prisoners was pluralistic and varied, and that after 1947 the state authorities began to suppress autonomous social initiatives. Centralization imposed a monolithic interpretation of recent history, implied a denial of the need for different associations, and yielded 
one of the peculiar features of communist memory politics by merging victims and veterans of the war under a single organizational roof. Chapter 3 examines the myth of victory over fascism in the Stalinist period. This dominant myth served the politics of the Cold War by deploying a narrative of the military glory of the Red Army and the Polish Armed Forces in the East, and sought to mobilize the masses into participating in state rituals at former Nazi camps. Simultaneously, the proponents of this myth excluded many individuals and groups by labelling them as traitors of their fatherland. Despite declaring 'unity', the myth atomized veterans' and victims' groups. Chapter 4 shows the results of the rejection of the Stalinist politics of memory by various social groups in 1956-57 and the negotiation of a new legitimizing narrative, the myth of the unity of the anti-Nazi resistance. The new myth rang in harmony with the patronage functions of the state towards former partisans and soldiers. Chapter 5 analyses the myth of the innocence of the Polish victims of Nazism in the light of both international politics within the German-Israeli-Soviet triangle and the anti-Semitic currents in Polish society in the 1960s. Finally, the Afterword explores the peculiarities of the Polish politics of the Second World War in the context of the Eastern Bloc as a whole, as well as presents some common threads of the communist politics of memory when compared with Western Europe; it also demonstrates the long-lasting effects of the communist politics of memory in present-day Poland.

This book was initially written for Polish readers. ${ }^{2}$ At the time it was conceived as having three principal purposes: to stimulate memory studies in Polish historiography; to bring history into sociology and vice versa; and to write a bottom-up history of communist Poland, which was still a rare approach at the time. When working on this project in the early 2000s, I was very much influenced by earlier rewritings of the histories of post-war (Western) European states. ${ }^{3}$ Even though important shifts in the study of both Poland and Europe have taken place since the book was published (memory studies and histories from below have become ubiquitous also in Eastern Europe, and European history now favours transnational treatments over studies of single states), it still remains the case that Poland's internal mnemonic conflicts in the aftermath of the war are largely unknown to international readers. For this reason, I have decided to introduce only minor revisions to the English edition.

2 The Polish edition appeared as Joanna Wawrzyniak, ZBoWiD i pamięć drugiej wojny światowej. 1949-1969, Warszawa 2009.

3 Such as István Deák, Jan T. Gross, and Tony Judt (eds), The Politics of Retribution in Europe: World War II and its Aftermath, Princeton 2000; Pieter Lagrou, The Legacy of Nazi Occupation: Patriotic Memory and National Recovery in Western Europe, 1945-1965, Cambridge 2000; Henry Rousso, The Vichy Syndrome: History and Memory in France since 1944, transl. A. Goldhammer, Cambridge, MA 1991. 
The English version has been shortened and slightly amended. It omits some facts, names, metaphors and quotations that could have seemed too detailed to non-Poles (such as various specifics of the wartime partisan movement). It also leaves out the literature review on memory studies in Poland. Instead, the English edition contains explanations of wartime and post-war events and organizations that would have been transparent to Polish readers. The original introduction has been replaced by this preface, and the epilogue by a new afterword that sheds a comparative light on the results of this study and invites readers to link the research findings on Poland with those in other European countries.

I am indebted to many individuals and organizations for the opportunity I have had to carry out this research. The book is based on my doctoral dissertation, defended at the Institute of Sociology at the University of Warsaw in 2007. The initial idea was conceived in 2000 when I attended a seminar course on 'Bad Memories' by István Rév at the Department of History at Central European University in Budapest. Further refinement of the study would have been impossible without the stimulating and generous support of my dissertation supervisor, Marcin Kula (Institute of History, University of Warsaw), a doctoral scholarship at the Institute of Sociology at the University of Warsaw, and regular contact with the Department for the Sociology of Work and Organizations at the Institute of Sociology. I was able to elaborate the theoretical foundations of the work and improve my knowledge of Polish-Jewish relations thanks to a fellowship at the Transregional Center for Democratic Studies at the New School for Social Research in New York (2001). The sociologist Barbara Szacka, one of the pioneers of memory studies in Poland, helped me greatly in getting acquainted with scholarship on collective and cultural memory. The staff of Polish state and regional archives provided indispensable assistance in finding source materials, and the individuals who agreed to share their experiences with me via interviews gave me fresh insights into the realities of the times.

In the course of writing, fragments of the eventual book were listened to by the participants of a doctoral seminar run by Włodzimierz Borodziej, Jerzy Kochanowski and Marcin Kula at the Institute of History at the University of Warsaw. I am grateful to these three professors and to all of my seminar colleagues for their many comments, criticisms and suggestions. I would particularly like to thank Błażej Brzostek, Małgorzata Mazurek, Zofia Wóycicka and Marcin Zaremba for in-depth discussions on specific topics. I also received kind assistance at numerous conferences in Poland and abroad and through written correspondence with numerous individuals. I am especially grateful to Krzysztof Ruchniewicz (Willy Brandt Centre for German and European Studies in Wroclaw) for providing 
me with a wealth of materials. When working on the final version of the Polish edition of the book, I was helped by the comments supplied to my doctoral thesis by its reviewers, Wiesława Kozek (University of Warsaw) and Dariusz Stola (Polish Academy of Sciences). Yet above all, I am indebted and thankful to my parents and husband for their continuing support.

The English version would have been impossible without the tremendous work of its translator, Simon Lewis, himself a scholar of Eastern Europe, who also drew my attention to many unclear formulations in the original. Further editorial work was undertaken by my husband Jan Wawrzyniak and final proofreading by Jan Burzyński. I would also like to express my sincere thanks to Dariusz Stola (again) and Machteld Venken (University of Vienna), who agreed to publish this book in their series 'Studies in Contemporary History' and offered valuable help and criticism in completing the manuscript. My thanks also go to historian Winson Chu (University of Wisconsin-Milwaukee) for his helpful suggestions on the English title. The generous support of Imre Kertész Kolleg in Jena (Germany), where I was a fellow in the academic year 2013/2014, allowed me to work on the manuscript and to consult recent literature on the topic. My thanks finally go to Łukasz Gałecki and Richard Breitenbach of Peter Lang for making this project feasible and for their patience. The English edition of this book was funded by a grant from the National Programme for the Development of Humanities of the Ministry of Science and Higher Education in Poland in 2013-15. 
Joanna Wawrzyniak - 978-3-653-99681-4

Downloaded from PubFactory at 01/11/2019 11:05:35AM

via free access 


\section{Chapter 1 \\ Communism, Myth and Memory}

\section{Collective Memory, Memory Groups and Myths of War under Communism}

The terms 'collective memory' and 'myth' tend to be overused in contemporary scholarship as catch-all concepts. Nonetheless, historiography would be poorer without them, and the history of victims and veterans of the Second World War would be near-impossible to write. In December 1945 the communist party leader Władysław Gomułka gave a speech, at the First Congress of the Polish Workers' Party, ${ }_{1}^{1}$ in which he set the tone of official remembrance for decades to come:

We came together as a Party during the period when Poland was lying in the grave of the Hitlerite occupation. We came together in order to fight, and we grew out of the fight with the German occupiers. At the very foundations of the Independence of Reborn Poland lie the blood and bones of thousands of members of our Party and soldiers who died in this struggle, who fought under our national flag. ${ }^{2}$

Seventeen years later, this fragment became the motto for a novella composed by another prominent communist, Mieczysław Moczar: Barwy walki ('The Colours of Battle') was published in several print runs and effectively founded an entire mythology around the communist partisans. ${ }^{3}$ Both Gomułka's speech and its indexing by Moczar point to the mythical origins of the new post-war state.

The 'memory boom' of the last three decades helps to shed light on attempts to construct such myths in the public sphere, despite controversies between scholars representing different stances in this expanding field. The authors of a

1 The Polish Workers' Party (Polska Partia Robotnicza, PPR) was a communist party in Poland from 1942 to 1948. It was founded as a continuation of the Communist Party of Poland (decimated in Stalin's purges of the late 1930s), and merged with the Polish Socialist Party (Polska Partia Socjalistyczna, PPS) in 1948 to form the Polish United Workers' Party (Polska Zjednoczona Partia Robotnicza, PZPR), which governed the country until 1989.

2 Władysław Gomułka, 'Przemówienie wygłoszone na otwarciu I Zjazdu Polskiej Partii Robotniczej’, 6 December 1945, in idem, Artykuty i przemówienia, vol. 1, Warszawa 1962, p. 415.

3 Mieczysław Moczar, Barwy walki, Warszawa 1979 [1962]. 
review article that analyses several hundred scholarly texts in a range of academic disciplines concluded some time ago that memory studies is 'a nonparadigmatic, transdisciplinary, centerless enterprise. ${ }^{4}$ Nonetheless, it is possible to classify the existing approaches to memory by examining the history of the concept, as well as the objects and methods of contemporary research. Such an undertaking reveals that the fields of sociology, cultural anthropology and social psychology have set the principal intellectual trends in memory studies. In particular, many scholars from these fields still rely on the work of Maurice Halbwachs, who in the interwar years coined the concepts of the 'social frames of memory' and 'collective memory' in his disputes with the subjectivist and individualistic theories of memory by Sigmund Freud and Henri Bergson. ${ }^{5}$ Halbwachs argued that the processes of recollection depend on the social conditioning of one's memory and on the social group to which the remembering individual belongs. Remembered 'histories' are thus subject to alteration, selection and reinterpretation. Although Halbwachs's theories have been criticized, for example for their lack of attention to the conflicts that result from different understandings of history or for overestimating the malleability of the past in the present, the term 'collective memory' and its various offshoots, such as 'sites of memory' and 'cultural memory', have embarked on a lightning career.

What is of interest here and may be termed the cultural approach in memory studies is based on analysis of the various products of culture that, depending on the methodological stance of a given author, are treated as representations and institutionalizations of some sort of 'collective consciousness' in the Durkheimian sense, or as products of the accumulation and interpenetration of various versions of the past. Among the contemporary classics who have provided such culturally oriented analyses are Jan and Aleida Assmann in Germany, as well as Pierre Nora in France. According to the Assmanns, cultural memory is a type of collective memory that is perpetuated by material forms and rituals. ${ }^{6}$ One of the most useful distinctions advanced by Aleida Assmann is that between 'storage memory' (Speichergedächtnis) and 'working memory' (Funktionsgedächtnis). The former

4 Jeffrey Olick and Joyce Robbins, "Social Memory Studies: From "Collective Memory" to the Historical Sociology of Mnemonic Practices', Annual Review of Sociology 24 (1998), p. $105,106$.

5 Maurice Halbwachs, Les Cadres sociaux de la mémoire. Paris 1925; idem, La Mémoire collective, edited by Gérard Namer, Paris 1997 [1950]. There are countless discussions of Halbwachs' theories. For a useful overview of the historical context of his theories in English, see: Patrick H. Hutton, History as an Art of Memory, Hannover 1993, pp. 73-90.

6 Jan Assmann, Das kulturelle Gedächtnis. Schrift, Erinnerung und politische Identität in frühen Hochkulturen, München 1992; Aleida Assmann, Erinnerungsräume. Formen und Wandlungen des kulturellen Gedächtnisses, München 2010. 
does not play any crucial role in the present (but might be activated one day), whereas the latter is important for the formation and maintenance of social identity. ${ }^{7}$

Pierre Nora's concept of 'sites of memory' (lieux de mémoire) refers to events, processes, real and imagined people, artefacts, symbols and other historical phenomena that crystallize and embed a national heritage. ${ }^{8}$ What is most appealing in the methodology employed by Nora, his collaborators and numerous followers is the focus on the dynamics of the making of a particular lieu de mémoire. Sites of memory have their long and fascinating histories, consisting of conflicts, alliances and compromises between various agents before they become widely accepted heritage.

'Social memory' is understood in a narrower sense by a group of psychologists who argue that memory is social only insofar as the processes of remembering and forgetting are conditioned by social interactions. ${ }^{9}$ A number of cultural historians, e.g. Jay Winter and Emmanuel Sivan, have offered similar methodological propositions. In their dispute with the French sociological and historical schools, they advance the thesis that it is individuals who act to commemorate, sometimes organizing themselves into groups, and that they should be the object of study. These historians raise justifiable concerns that the term collective memory can lead to unnecessary abstraction:

The 'collective memory' of war is not what everybody thinks about war; it is a phrase without purchase when we try to disentangle the behaviour of different groups within the collective. Some act; others - most others - do not. Through the constant interrogation of actors and actions, we separate 'collective memory' from a vague wave of associations which supposedly come over an entire population when a set of past events is mentioned. ${ }^{10}$

Thus, what recent scholarship in memory studies teaches us is that collective memory is not just a collection of ideas about the past but, above all, a product of communication. In this process, private and vernacular memories are transformed into narratives that feature elements of 'invented tradition', and these are in turn

7 Aleida Assmann, 'Speichergedächtnis und Funktionsgedächtnis in Geschichte und Gegenwart' in Peter Rusterholz and Rupert Moser (eds), Wir sind Erinnerung, Bern 2003, pp. 181-196.

8 Pierre Nora (ed.), Les Lieux de mémoire, vols 1-7, Paris 1984-92. The term lieux de mémoire has been translated into English as 'sites of memory' or 'realms of memory'. In this book we have opted for 'sites of memory'. (Author and translator's note.)

9 David Middleton, Derek Edwards, 'Introduction', in David Middleton, Derek Edwards (eds), Collective Remembering, London 1990, pp. 1-22.

10 Jay Winter and Emannuel Sivan, 'Introduction' in Jay Winter and Emannuel Sivan (eds), War and Remembrance in the Twentieth Century, Cambridge 1999, p. 9. 
transmitted to new members of social groups as the official history of the group, ${ }^{11}$ which can be also termed 'public memory'. ${ }^{12}$

I will go no further into the depths of the terminological disputes; as a historian of ideas once wrote: 'venturing into this terrain lets us neither leave it nor solve any of its problems. ${ }^{13}$ In this book I use the term 'public memory' to refer to cultural representations of the past, but I am mainly interested in the actions and processes that influenced and conditioned these representations in the first place. I follow a considerable number of authors who claim that one of the most important elements of nation-building is the imposition by the power elites of a shared ('working') memory; i.e., elites' attempts to convince society that there is a common past by enacting various rituals, symbols, and other widely available products of culture. ${ }^{14}$ Representations of war are frequently at the very centre of such a consolidated memory. In order to interpret the cultural history of the nation state, however, we must analyse more than just the symbolic content of such sites of memory; it is necessary to examine the distinct agencies that create narratives about the past. ${ }^{15}$

In this respect I find the notion of 'memory groups' - as proposed, for instance, by Harold Marcuse - particularly useful. 'Such groups usually share common experiences and goals, as well as images of the past ... Individuals who accept the memories, values, and aspirations become part of a memory group; members who no longer share them, leave it. ${ }^{16}$ Veterans, mothers of fallen soldiers, or camp victims might organize themselves in an official manner, but may also do without any formal structure; and they often exert pressure on the state in matters regarding policies of memory and commemoration.

At the same time, the category of 'myth' can help us to grasp these forms of collective memory that function as metanarratives about the past. As a story about origins, a myth serves cognitive, integrative, communicative and legitimizing functions, and in modern times is often advanced by the state. The time of myth is

11 Sławomir Kapralski, 'Oświęcim: konflikt pamięci czy kryzys tożsamości?', Przegląd Socjologiczny 2, 49 (2000), p. 143.

12 Cf. Kendall R. Phillips, 'Introduction' in Kendall R. Phillips (ed.), Framing Public Memory, Tuscaloosa 2004, pp. 1-16.

13 Marcin Król, 'Ewolucja, restauracja, amnezja. O pamięci w czasach postkomunistycznych', Res Publica 5, 43 (1991), p. 18.

14 See: Benedict Anderson, Imagined Communities: Reflections on the Origin and Spread of Nationalism, London 1983; Ernest Gellner, Nations and Nationalism, Ithaca 1983; Eric J. Hobsbawm, Nations and Nationalism since 1788: Programme, Myth, Reality, Cambridge 1990.

15 Olick and Robbins, p. 112.

16 Harold Marcuse, Legacies of Dachau: The Uses and Abuses of a Concentration Camp, 1933-2001, Cambridge 2001, p. 14. 
'a rejection of historicity', a liberation from linear time, and enacting of the past in the present. Myth is recognizable above all in the system of symbols and rituals. ${ }^{17}$ Various memory groups might organize their stories and actions according to a myth, and they may contest dominant myths.

Political myth is a specific variety of myth: it contains the symbolic representations of power and justifies the political status quo. Two types of political myth are central to this study: revolutionary and national. The former divides time into the old and the new; this division is manifested in the system of symbols (new man, new society, etc.) and in utopian thinking - promises of a new, good and happy life. Revolutionary myth also demands the destruction of the residues of the past. Meanwhile, national myth is centred around the national collective with strong references to its historicity; and in the case of Eastern European societies, described by the Polish-French historian Bronisław Baczko as 'unhappy', the nation is often imagined as a lost land that must be regained..$^{18}$ Another prominent feature of Eastern European national mythology is messianism, in which the nation is construed as a saviour and martyr sacrificed for the redemption of traditional values.

It has been also widely argued that Marxist thought had a mythical structure. The struggle of the proletariat with the bourgeoisie was presented as the final battle between good and evil. The struggle and suffering of the communist redeemer led to an ontological change in the order of the world, including the creation of the 'state of the Sun', or 'kingdom of freedom'; a society without class divisions and ethnic belonging would be both the beginning and the end of history. ${ }^{19}$ In the political practice of communism in many countries, however, the proletariat was replaced by the 'nation' as a key category of state propaganda. Especially in Eastern Europe, the revolutionary and the national became intertwined for political reasons, creating a new wholeness. The revolutionary upheavals that uprooted the existing political and social order did not automatically result in changes within the vernacular memories that continued to strive to commemorate the past and seek sources of identity in bygone history. The revolutionaries were forced to create a vision of the nation's past according to which they would be

17 Elżbieta Tarkowska, Czas w spoteczeństwie. Problemy, tradycje, kierunki badań, Warszawa 1987, pp. 50f; George Schöpflin, The Functions of Myth and a Taxonomy of Myths, in Geoffrey Hosking and George Schöpflin (eds), Myths and Nationhood, New York 1997, pp. 19-35.

18 Bronisław Baczko, Les Imaginaires sociaux. Mémoires et espoirs collectifs, Paris 1984. See also: Tadeusz Biernat, Mit polityczny, Warszawa 1989, pp. $213 \mathrm{f}$.

19 Mircea Eliade, Mythes, rêves et mystères, Paris 1957, pp. 20f; Leszek Kolakowski, Main Currents of Marxism, transl. P.L. Falla, vol. 3, Oxford 1981, pp. 523f; Jan Prokop, Wyobraźnia pod nadzorem. Z dziejów literatury i polityki w PRL, Kraków 1994, p. 40, 41. 
seen as the most legitimate holders of power. Such a task entailed gaining control over the existing narratives of the past - otherwise these narratives would become a resource for the enemies of revolution. This is why the new political authorities did not only eliminate old representations of the past (sometimes by force), but also creatively adapted the existing images, symbols and rituals. ${ }^{20}$

There exists a substantial scholarly literature that examines this process as the gradual nationalization of the communist system in the USSR and the countries of Central and Eastern Europe. ${ }^{21}$ For instance, Christel Lane has analysed socialist rituals, arguing that from the 1960s onwards the role of myth was to stabilize the system, rather than to provide guidelines for future action; the Marxist-Leninist elements of the rituals were overshadowed by patriotism. Lane shows that various rituals observed by the Pioneers (the communist children's organization), workers' collectives and soldiers, and even rites conducted in civil registry offices, sanctified the past and not the future. Moreover, mythologized history was rarely the history of the October Revolution alone; the Great Patriotic War, as the Second World War was known in the USSR, was often an equally important event. ${ }^{22}$

Amir Weiner has analysed the role played by the myth of the Great Patriotic War in connecting the revolutionary and national liturgies. ${ }^{23}$ A representative of 'revisionist' historiography in the USA, Weiner examines the institutionalization of the myth of the war on the example of the region of Vinnytsia in central Ukraine, and analyses the myth as an essential instrument for social engineering. In official Soviet ideology, the war was presented as a step taken by the masses towards

20 Andrzej Szpociński, 'Społeczne funkcjonowanie symboli' in Teresa Kostyrko (ed.), Symbol i poznanie. W poszukiwaniu koncepcji integrujacej, Warszawa 1987, pp. 21f. For a detailed account of the formation of holidays and festivals in communist Poland and the adaptation of the traditions of the inter-war period and the Catholic Church, see Izabella Main, Trudne świętowanie. Konflikty wokół obchodów świą państwowych i kościelnych w Lublinie (1944-1989), Warszawa 2004. On the origins of secular holidays in communist Poland, see Piotr Osęka, Rytuały stalinizmu. Oficjalne święta i uroczystości rocznicowe w Polsce 1944-1956, Warszawa 2007.

21 See for instance: Yitzhak M. Brudny, Reinventing Russia: Russian Nationalism and the Soviet System, 1953-1991, Cambridge 1998; Marcin Kula, Narodowe i rewolucyjne, London 1991, pp. 93-149; Katherine Verdery, National Ideology under Socialism: Identity and Cultural Politics in Ceausescu's Romania, Berkeley 1991; Marcin Zaremba, Komunizm, legitymizacja, nacjonalizm. Nacjonalistyczna legitymizacja władzy komunistycznej w Polsce, Warszawa 2001; Peter Zwick, National Communism, Colorado 1983.

22 Christel Lane, 'From Ideology to Political Religion: Recent Developments in Soviet Beliefs and Rituals in the Patriotic Tradition' in Claes Arvidsson and Lars E. Blomqvist (eds), Symbols of Power: The Esthetics of Political Legitimation in the Soviet Union and Eastern Europe, Stockholm 1987.

23 Amir Weiner, Making Sense of War: The Second World War and the Fate of the Bolshevik Revolution, Princeton 2001. 
communism. However, the war altered the revolutionary conception of the political community: class-based solidarity was displaced by the bonds that resulted from blood spilled in the name of the fatherland. The war also changed the archetypal hero: from the 'revolutionary' to the 'defender of the Soviet Union'. Similarly, the ideal enemy also changed, from the 'kulaks' and the 'enemies of the revolution' to 'traitors' and 'collaborators'. Thus the myth of the war transformed the basic categories and relations operating in Soviet society. According to Weiner, however, the myth became embedded in society not primarily because it was the object of special political manipulation, but because the war had genuinely affected social life; the myth was sustained not only by communist institutions and activists, but also by informal structures. For this reason, the attempt to legitimize the political system on the basis of the public memory of the war was much more effective than the ideology of revolution. The myth of the Great Patriotic War was popular to such an extent that it survived Perestroika. ${ }^{24}$

The social reality of communism was an enchanted reality, despite its appeal to rationalism. Also in communist Poland, one of the principal legitimizing strategies employed by the authorities was the saturation of the propaganda with historical figures and events, alongside either the co-optation or delegitimization of traditional, pre-communist narratives ${ }^{25}$ Historian Edmund Dmitrów has proposed that the Polish communists' propaganda be understood in terms of the foundational myth of the victorious war over Germany. ${ }^{26}$ This myth made it possible for the idea of victory to be given many different meanings, each facilitating the legitimization of the political order and the integration of society into the communist system. It repeated certain patterns of Soviet ideology, but at the same time, the symbol of a Polish military unit conquering Berlin was a viable and attractive alternative to the national complex of defeat and eternal victimhood. May 1945 appeared as a 'better version of Grunwald' (i.e. the battle of 1410 in which the Teutonic knights were defeated by combined Polish-Lithuanian forces): it purportedly eliminated the threat that had 'hung over Poland for thousands of years.' The myth of victory was designed, in Dmitrów's opinion, to 'encourage people to identify with the values that the political system attributed to itself, including strength, security, progress, development and justice. ${ }^{27}$

In the following chapters, I examine the social genesis and functioning of three narratives about the war: the myth of victory, as depicted by Dmitrów; the

24 See also: Nina Tumarkin, 'The Great Patriotic War as Myth and Memory', European Review 4, 11 (2003), pp. 595-611.

25 Zaremba, Komunizm, legitymizacja, nacjonalizm, passim.

26 Edmund Dmitrów, 'Pamięć i zapomnienie w stosunkach polsko-niemieckich', Przeglad Zachodni 1, 45 (2000), p. 2.

27 Ibid., p. 7. 
myth of the unity of the Polish resistance movement; and the myth of Poles as innocent victims. All three were political myths that played a role in the spectacle staged by the communist authorities in Poland; they also supplied meaning to the experience of war. The most complete of them, foundational for the system of power, was the myth of victory over 'fascism' ${ }^{28}$ At its base was a Manichean division into the 'camps' of socialism and capitalism. A tale of the struggle of good against evil was inscribed into the events of the Second World War, also harking back to earlier historical origins such as the October Revolution of 1917 and the birth of the Polish proletariat in the nineteenth century. However, the myth of victory did not always fulfil an integrative function. In Stalinist times, it was a narrative used to ostracize unwelcome memory groups by means of false accusations of having collaborated with the Nazis. The myth's legitimizing function was oriented externally: it was designed to explain and justify the communist rule in Poland as a necessary outcome of the international relations of the Cold War. The communists, labelled 'fighters for peace', were allegedly the only true victors over Nazi Germany, whereas the capitalist, insufficiently de-Nazified West was supposedly preparing a third world war; i.e., according to the Soviet propaganda, it was continuing 'Hitler's deed'. Only after the Thaw of 1956 did the war contribute to the creation of community, bringing together a divided Polish society. The myth of victory was then supported by related myths of the unity of the resistance movement and of innocent victims; together, these narrative and symbolic constructs played a vital and paradoxical role in the nationalist legitimization of the communist authorities in Poland.

\section{Agents: Veterans, Victims and the Nation State}

How do the veterans and victims of the Second World War interplay with all the matters discussed above? Analysing the legacies of war in France, Henry Rousso has distinguished four basic institutions engaged in the production of war memories. The first is the state itself, which usually offers an overall monolithic interpretation of the past. This memory is manifested in monuments, official

28 The catch-all term 'fascism' in Eastern Bloc is sometimes confusing. During the war, Soviet propaganda kept calling Germans 'fascists' because it considered 'fascism' to be the last degenerated stage of capitalism that led to war. Later, during the Cold War (especially until 1956), the propaganda in communist countries labelled as 'fascist' nearly anybody who was not in favour of the influence of the Soviet Union in Eastern Europe. It is also important to note that in Poland, in the official memory of war, the very term 'German' was rarely used due to the friendly relations with 'innocent' East Germany. 'Nazism' was also rarely in use and more frequent was the term 'Hitlerism', which often superseded 'fascism'. 
commemorative ceremonies, and also in the implementation of law (e.g. in court judgements). The second are community associations, such as unions of war veterans or of victims of racial persecution, established both to preserve memories of the war and to lobby and pressurize the state. Third, Rousso identifies culture and the creators of images and narratives that influence the popular imagination, especially through literature and film. Fourth, he points to scholarship, both as practised by professional historians working within the academic field, and as it influences educational programmes and textbooks - the basic media in the modern nation state through which memory is passed to latter generations, and thereby becomes a tool for socialization. ${ }^{29}$

The people who are the focus of this book operate mainly within the first two levels of the institutional architecture suggested by Rousso, occasionally venturing into the third. Although their story is played out in the newly built communist bloc, there is little that is historically exceptional in their fate. Casting a light on the broader history of war veterans in Europe allows us to search for similarities, analogies and differences in the longue durée. Interaction between political structures and former soldiers goes back at least as far as ancient Rome, where the status of a veteran was a kind of retirement attained by legionnaires and soldiers of assistive divisions. However, the relationship between the state and veterans had a specific character in the modern nation state, the product of political mobilization and the increasing uniformity of culture. Both the defence and expansion of national territory became a justification for struggle and physical suffering. Throughout Europe in the nineteenth and twentieth centuries, the image of the soldier heroically fighting for his country was a universal cultural symbol. The nationalisms of the turn of the twentieth century were military in nature; ${ }^{30}$ the army was one of the most important institutions in which the levelling of divisions of estate took place, in the era of accelerated modernization. ${ }^{31}$ The nineteenth and twentieth centuries were characterized by the cult of military heroism, as well as by its democratization - the feats of the simple and anonymous soldier were increasingly recognized and placed on a pedestal. Although the modern nation state often placed the cult of the dead above the cult of the living,${ }^{32}$ former soldiers

29 Rousso, pp. 219-221.

30 Joanna Kurczewska, 'Nacjonalizm i rzeczywistość mityczna' in Edmund Mokrzycki, Maria Ofierska and Jerzy Szacki (eds), O społeczeństwie i teorii społecznej. Księga poświęcona pamięci Stanisława Ossowskiego, Warszawa 1985, pp. 496-505.

31 Eligiusz Kozłowski, 'Armia' in Witold Kula and Janina Leskiewiczowa (eds), Przemiany społeczne w Królestwie Polskim 1815-1864, Wrocław 1979, p. 199.

32 John R. Gillis, 'Memory and Identity: the History of a Relationship' in John R. Gillis (ed.), Commemorations: the Politcs of Identity, Princeton 1995, p. 11; Thomas W. Laquer, 'Memory and Naming in the Great War' in ibid., pp. 150-167; Daniel J. Sherman, Art, 
made up a specific category that linked the living and the deceased, because they had fought and suffered together with the people who died in the name of the fatherland. The veterans were 'living symbols' and 'living witnesses' of the heroic past, as well as an embodiment of the idea of the nation state.

This relationship between the state and the cult of the soldier, however, did not in general mean that the European state was the principal initiator of the veterans' organization. Indeed, the opposite is true: in the majority of cases, associations have been founded through initiatives at the grassroots level. An important practical reason for soldiers to unite was to lobby for the group's interests. The first veterans' organization in the history of the Prussian army was the militärische Schützenbruderschaft (Military Brotherhood of Defence), established in 1786 in Pomerania by former fusiliers. One of its main aims was to gather funds for the burial of deceased comrades. The number of Prussian veterans' associations increased steadily as more wars were waged; each was supported by members' fees and private donations. ${ }^{33}$ At the beginning of the twentieth century, the Deutscher Kriegerbund (German Warrior League), a federation of veterans' organizations that had over a million members in total, created a unified system of finance that organized welfare payments, set the level of membership fees, and gathered surplus monies from interest on capital as well as from various commercial initiatives, such as fencing schools. ${ }^{34}$

The Great War was another important caesura in the history of European veterans' movements: 'veterans emerged as a distinct group, defined by a construction of war commemoration and identity as well as by their legal demands and rights. ${ }^{35}$ Nonetheless, material interests still played an important role, and were for instance the main impulse for the establishment of veterans' associations in Poland after the country had regained its independence (1918) and defended its borders in the Polish-Soviet War (1919-21). By 1922, 800,000 soldiers had been demobilized. Marek Jabłonowski writes: 'Frontline soldiers were returning, dressed in rags. Officers had received severance packages that did not cover a modest living. In addition, the economic situation throughout the country was

Commerce, and the Production of Memory in France after World War I, in ibid., pp. 186214; George L. Mosse, Fallen Soldiers: Reshaping the Memory of the World Wars, Oxford 1990, pp. 70-106.

33 Piotr Wróbel, Droga powrotna. Niemiecki prawicowy ruch kombatancki po I wojnie światowej, Warszawa 1989, pp. 27-33.

34 Marek Jabłonowski, Polityczne aspekty ruchu byłych wojskowych w Polsce, 1918-1939, Warszawa 1989, p. 13.

35 Julia Eichenberg and John Paul Newman, 'Introduction: The Great War and Veterans' Internationalism' in Julia Eichenberg and John Paul Newman (eds), The Great War and Veterans' Internationalism, London 2013, p. 1. 
worsening: the black market was burgeoning, inflation was on the rise and work was increasingly hard to find. ${ }^{36}$ Veterans not only formed unions; they also established co-operatives, companies and collaborative workshops in order to earn an income. ${ }^{37}$

Similarly in France, where social support for disabled people has a long history (with the telling example of the Hotel des Invalides, built at the end of the seventeenth century), the insufficient state provision for former soldiers after the Great War was one of the main reasons behind the establishment of veterans' associations. Numerous unions were founded by soldiers who were no longer able to continue their military careers or return to normal life; some could not even return to their families. ${ }^{38}$ The objectives of these unions included both lobbying the state for permanent financial support and creating support groups for former combatants to alleviate their despair. ${ }^{39}$

The public recognition of war veterans is most clearly illustrated by the Fasci di Combattimento in early-twentieth century Italy. The ideology of fascism attached a great value to frontline experience, also placing a symbolic premium on heroic death and physical injury. It sacralized the common struggle and a community of spilled blood. ${ }^{40}$ As many scholars have shown, fascism sought to draw on a wounded sense of national pride and dashed hopes at the level of everyday life. A similar role was played by right-wing veterans' organizations in the Weimar Republic. Large numbers of discharged officers and soldiers of the republic's

36 Jabłonowski, p. 19.

37 For more on Polish inter-war veterans, see Julia Eichenberg, Kämpfen für Frieden und Fürsorge. Polnische Veteranen des Ersten Weltkriegs und ihre internationalen Kontakte, 1918-1939, München 2011; Marcin Jarząbek, 'The Victors of a War That Was Not Theirs: First-World-War-Veterans in the Second Republic of Poland and Their European Peers', Acta Poloniae Historica 1, 111 (2015), pp. 83-105.

38 Antoine Prost, Les Anciens combattants et la societé française, 1914-1930, vol. Histoire, Paris 1977, pp. 7-45, 145-159.

39 Jay Winter, 'Forms of Kinships and Remembrance in the Aftermath of the Great War' in Winter and Sivan, pp. 49-51. Also during the Great War, the Polish disabled soldiers created one of the first organized veterans' associations. They first came together in 1915 in Kraków, in a school for disabled children that they believed would help them to adapt to a working life and enable independent living. Jabłonowski, pp. 31f; Jan Z. Mierzwa, Kombatancki Kraków 1918-1938, Kraków 2002, p.14, 15. In the Partition period (1795-1918) the only Polish veterans' organizations existed in Austrian-controlled Galicia (after 1870): the First Corps of the C.K. Military Veterans (I Korpus C.K. Weteranów Wojskowych) and the Polish Association of Military Veterans (Polskie Towarzystwo Weteranów Wojskowych).

40 Emilio Gentile, The Sacralization of Politics in Fascist Italy, transl. Keith Botsford, Cambridge, MA 1996, pp. 19-31; Simonetta Falasca Zamponi, 'Of Storytellers and Master Narratives: Modernity, Memory, and History in Fascist Italy', Social Science History. Special Issue: Memory and the Nation, 4, 22 (1998), pp. 424-426. 
army struggled to find employment, and neither their qualifications nor the general economic situation helped their cause. Despite deaths and injuries, the soldiers' experiences at the front provided grounds for a belief that an association of men who had together spilled blood was the only dignified type of social organization for a country recovering from military defeat. ${ }^{41}$

Nonetheless, the ideological dimensions of veterans' organizations should not be interpreted only in terms of the categories applicable to fascism, for two main reasons. First, many veterans had never been frontline soldiers. The example of inter-war Poland shows that in countries with a history of fighting for independence, veterans' privileges were often granted to non-professional soldiers: Polish legislation and culture recognized not only former soldiers of Józef Piłsudski's legions, the wounded in action, and other categories of regular soldiers, but also the insurgents of the January Uprising (1863), the Silesian Uprisings (1919-21) and the Wielkopolska Uprisings (1918-19). Victims of Tsarist-era deportations to Siberia were also given special privileges and social recognition. ${ }^{42}$ Second, and more importantly, veterans do not necessarily profess right-wing views. The French historian Antoine Prost has studied the fascinating case of French veterans after the First World War, many of whom declared pacifist views ${ }^{43}$ and contributed to the 'moral disarmament' of the French society. ${ }^{44}$ Many soldiers sympathized with communism. They rejected nationalist ideology as opium fed to them in the battleground, where - in their opinion - they had fought to defend the interests of the bourgeoisie. Class-based justice was a central concern for many soldiers, although some were convinced that it could be achieved even within a nation state. Thus, the ideas and social practices of the veterans' movements formed in the nineteenth and early twentieth centuries had a variety of functions in response to a range of social needs.

The third major caesura in the history of veterans' organizations was the Second World War: throughout Europe, the distinction between soldiers and civilians became rather blurred. In addition to traditional veterans' organizations (i.e. unions of soldiers), numerous associations of former resistance fighters and victims of persecution were formed. The members of these victims' unions constructed their identity on the basis of their wartime sufferings, which were

41 Norbert Elias, The Germans: Power Struggles and the Development of Habitus in the 19th and 20th Centuries, Cambridge 1996; Richard Grunberger, A Social History of the Third Reich, London 1971; George L. Mosse, The Crisis of German Ideology: Intellectual Origins of the Third Reich, New York 1964.

42 Jabłonowski, pp. 166-179; Mierzwa, p. 6.

43 Prost, Les Anciens combattants, vol. Mentalités et idéologies, Paris 1977, pp. 78-119.

44 Mona L. Siegel, The Moral Disarmament of France: Education, Pacifism, and Patriotism, 1914-1940, Cambridge 2011. 
very different from the experiences of soldiers at the front. According to Pieter Lagrou, in Western Europe this divergence was a fundamental challenge for the politics of national memory:

There was no homogenous and properly national milieu de mémoire such as the veterans of the First World War had created, as conscripts of a national army. The soldier-hero was replaced by much more controversial hero-types: terrorist guerrillas, often primarily engaged in an ideological battle. Many were foreigners, and even more numerous were the communists who fought for an ideal seen as anti-national by traditional patriots ... The problem of interpretation was greater still for the martyrs: no fallen soldiers, but tens of thousands of civilian victims of ideological persecution and genocide ... And what was the legacy of the labour conscripts, taken to Germany against their will but working for the Nazi economy? Contrary to the homogenising effects of the First World War, the consequences of the Second World War need to be studied in specific groups, identified according to their specific war experience, and not according to pre-established categories of analysis. ${ }^{45}$

Nonetheless, the nation state remained an important point of reference for veterans' and victims' organizations. Various unions not only pressured the state for reparations and social welfare support; they were also important media for the post-war reconstruction of national communities and their symbols. However, as a result of the differentiation of memory groups, this process was not devoid of conflict. In France, the country for which scholarship on this subject is most abundant, disputes between different interest groups, sometimes dramatic in nature, overlapped with political divisions and attempts to rehabilitate collaboration with the Nazis. ${ }^{46}$ Official symbolism was a domain over which the power elites and interest groups constantly argued: the meaning of patriotism and the conception of national martyrdom and suffering were among the contested ideas. ${ }^{47}$ For example, conflicts between the Fédération Nationale des Déportés et Internés de la Résistance (National Federation of Deportees and Internees of the Resistance Movement, an organization that brought together former political prisoners associated with the non-communist resistance movement) and the Fédération Nationale des Déportés et Internés Résistants et Patriotes (National Federation of Deported and Imprisoned Resistance Fighters and Patriots; a left-wing organization that united members of the resistance and victims of persecution, particularly Jews) resulted from different understandings of the concept of 'resistance': the former took a more traditional viewpoint (that of a soldier and warrior) whereas the latter advanced an egalitarian idea of mass combat. Soldiers from the Second

45 Lagrou, p. 3, 4.

46 In 1951 the Association pour Défendre la Mémoire du Maréchal Pétain (Association for the Defence of the Memory of Marshal Pétain) was formed. Its activities were never banned. Rousso, The Vichy Syndrome, pp. 43-49.

47 Lagrou, pp. 226-234. 
World War who aspired to the special privileges of war veterans, in particular long-serving prisoners-of-war, were confronted with the disapproval of the Union Française des Anciéns Combattants (French Union of Former Combatants), who maintained that soldiers who had surrendered were not worthy of recognition as veterans. It was in the heat of these debates in the 1950s that three important and mutually hostile ex-combatants' organizations were founded. ${ }^{48}$ An additional complication was provided by the Cold War: in national organizations in Western Europe, new divisions appeared along the lines of the German question and the vision of a united Europe, inspired by international veterans' organizations: the communist Fédération Internationale des Résistants (FIR, International Federation of Resistance Fighters) and its opponents, the Fédération Internationale Libre des Déportés et Internés de la Résistance (FILDIR, Free International Federation of Deportees and Internees of the Resistance), the Union Internationale de la Résistance et de la Déportation (International Union of Resistance Fighters and Deportees) and the Union de la Résistance pour une Europe Unie (Union of Resistance Fighters for a United Europe). ${ }^{49}$

In summary, veterans' organizations emerged on a wide scale when the modern nation state became consolidated. Veterans were seen as an embodiment of the values propounded by the state, but those values were also subject to debate. At the same time, in an ideologically conducive atmosphere, veterans used their organizations as instruments for pressurizing the state, making material demands and asserting their identity. This book relates the Western European history outlined above to the experiences of veterans and victims in an East European communist state. In Eastern Europe, described as the 'Bloodlands' by Timothy Snyder, millions lost their lives or their health in both Hitler's and Stalin's atrocities, as well as in effect of local vendettas and ethnic cleansing. ${ }^{50}$ Obscuring the identities of many

48 The left-wing Association Nationale des Anciens Combattants de la Résistance (National Association of Former Resistance Fighters), and the Gaullist Association Nationale des Combattants Volontaires de la Résistance (National Association of Volunteer Resistance Fighters) and Confédération Nationale des Combattants Volontaires de la Résistance (National Confederation of Volunteer Resistance Fighters). Lagrou, pp. 42-47.

49 Ibid., pp. 262-285.

50 According to Timothy Snyder, 14 million civilians and PoWs were killed between the years 1933 and 1945 in Eastern Europe, and a substantial portion of the atrocities committed by the Stalin and Hitler regimes took place in Poland, Ukraine, Belarus, western Russian and the Baltic States. Cf. Timothy Snyder, Bloodlands: Europe between Hitler and Stalin, New York 2010. Critics accuse Snyder of employing arbitrariness in his work's chronological frames as well as in the geographical boundaries of the 'Bloodlands', supplying inaccurate figures, belittling the significance of the Holocaust, and ignoring the roles played by local collaborators in mass murder (including a pro-Polish bias that allegedly permeates the work). Positive reviews give justifications that mirror these criticisms: the book is 
victims and perpetrators, the communist states simultaneously advanced heroic and martyrological narratives, because these were best suited to the legitimization of communist rule in the region. At the same time, various memory groups strove for their version of history, despite the authoritarian constrains.

When the original, Polish version of my book appeared in 2009, a number of near-simultaneous publications supplied findings that corresponded with my own. In his superb work on the social history of Soviet veterans, Mark Edele ${ }^{51}$ analyses the rise of the veterans' movement in the USSR from its beginnings in the immediate post-war period, when it was not officially welcome, to the cult of the war under Leonid Brezhnev's leadership, with its favourable climate for transforming veterans into 'a status group' benefitting from 'scarce goods, services, and esteem' despite shortages of the communist economy. ${ }^{52}$ Edele's story ends with the veterans established as 'an institutionalized pillar of the political system' ${ }^{53}$ so powerful that they could saturate the new political agenda after 1991 with the ideology of the Great Patriotic War. The history of the Soviet Committee of War Veterans (Sovetskii Komitet Veteranov Voiny, SKVV), as described by Edele, resembles that of the main agent of this book: the Polish counterpart of SKVV, the Union of Fighters for Freedom and Democracy (Zwiazek Bojowników o Wolność i Demokrację) which also rose to prominence in the 1960s. Similarly to SKVV, ZBoWiD "was not simply a recognition "from above" of popular aspirations, but rather an appropriation "from below" of an institution which was created for fundamentally different purposes. ${ }^{54}$

Comparable claims have also been advanced by Heike Karge with regard to the case of Yugoslavia, although her study focused less on social entitlements and more

praised for its methodological innovation in demonstrating the transnational dynamics of mass murder and its introduction of 'new' categories of victims into scholarly historical discourse, able use of statistics and personal accounts, and sensitivity to the different narratives dominant in several national historiographies. See e.g. Omer Bartov's book review in Slavic Review 2, 70 (2011), pp. 424-428; 'Bloodlands - eine Debatte über die Massenmorde der stalinistischen Sowjetunion und NS-Deutschlands' (discussion featuring Manfred Hildermeier, Dariusz Stola, Dietrich Beyrau, Sybille Steinbacher, Dan Michman and Johannes Hürter), Journal of Modern European History 3 and 4, 10 (2012), pp. 289314, and pp. 433-451; 'Review forum: Timothy Snyder, Bloodlands: Europe between Hitler and Stalin' (discussion featuring John Connelly, Mark Roseman, Andryi Portnov, Michael David-Fox and Timothy Snyder), Journal of Genocide Research 3, 13 (2011), pp. 313-352.

51 Mark Edele, Soviet Veterans of the Second World War: A Popular Movement in an Authoritarian Society, 1941-1991, Oxford 2008.

52 Ibid., p. 185.

53 Ibid., p. 181.

54 Ibid., p. 162. 
on the forms of cultural and social remembrance instigated by the Union of Fighters in the War of National Liberation (Savez Boraca u Narodnooslobodilačkom ratu u Jugoslaviji, SBNORJ). Karge describes the diverse commemorative practices of this organization, which were hidden behind politically controlled narratives. Karge also notes that an important shift took place in the union's activities in the 1960s: from actions targeted at the war generation to those aimed at the emerging generation that lacked first-hand experience of the war. ${ }^{55}$ This shift, also observable in Polish ZBoWiD at the same time, would have a profound impact on subsequent memory politics in both countries.

Finally, a recent book by Philipp Neumann-Thein shows that there were a variety of remembrance activities behind the official curtain of the memory politics of the German Democratic Republic (GDR) with regard to the victims of Nazi camps. ${ }^{56}$ An orientation towards the camps' victims (who, by the way, for long had been marginalized by the official remembrance of the USSR) was also an important feature of memory policy from the very beginning of communist rule in Poland. The Polish communists relied a lot on their ties with the East German Association of Persons Persecuted by the Nazi Regime (Vereinigung der Verfolgten des Naziregimes, VVN), as well as with the International Committee of Buchenwald-Dora. Despite the diversity of memorial practices, the main patterns of commemoration were to a large extent politicized, and some GDR blueprints were transferred to Poland. One of the salient features of this transfer was the heroization of victims of racial persecution in Poland (Jews and Slavs); camps' victims were put on an equal footing with former fighters by being turned into martyrs for a revolutionary or national cause.

\section{Structures: Organizations in the Communist System}

Examining the post-war veterans' and political prisoners' movements from an Eastern European perspective brings us to another dimension of this book, which is a return to the discussion on the seemingly totalitarian traits of the communist state. Let us consider some of the classical terms of this debate. According to the conception advanced decades ago by Carl J. Friedrich and Zbigniew Brzeziński, there are six features of a totalitarian system: (1) a ruling ideology or official doctrine that embraces all essential aspects of human existence; (2) a single mass

55 Heike Karge, Steinerne Erinnerung - versteinerte Erinnerung? Kriegsgedenken in Jugoslawien (1947-1970), Wiesbaden 2010.

56 Philipp Neumann-Thein, Parteidisziplin und Eigenwilligkeit. Das Internationale Komitee Buchenwald-Dora und Kommandos, Göttingen 2014. 
party dominated by a dictator; the party is hierarchical, blindly submissive, devoted to the ideology, and closely intertwined with the ruling bureaucracy; (3) terror, directed not only at the enemies of the regime, but also exerted arbitrarily against various population groups; (4) full control over the means of mass communication; (5) a monopoly of use of all kinds of weaponry; (6) an economy that is entirely subject to centralized control and bureaucratic management. ${ }^{57}$

Within this model, there is essentially no point in asking what role veterans' unions (or any other large state-sponsored organizations) played in society: their function could only be to ensure control of the rulers over the ruled and to transmit the official ideology to the people. The organizations' structure seemed conducive to these aims: they mimicked the structure of the communist party and reflected the principles of democratic centralism, according to which higher structures had a clear supremacy over lower ones, and decisions flowed from top to bottom. For instance in Poland, most of the communist mass organizations divided their members into groups (koła, literally, 'circles'; these numbered from less than a dozen to several hundred individuals) based in geographic areas; sometimes, such groups were created within places of work. The group were subordinate to directorates (zarzady), which comprised the next administrative level. The directorates created a system for monitoring the population, which was complemented by additional supervision of the regional and central party organizations. Such an organizational structure, with controlled elections within a multi-layered system was designed to make the state authorities more appreciative of the powers-that-be.

The totalitarian model of communism has had a significant influence on the scholarly literature during the Cold War, and was also an important point of reference for opposition movements in many countries of the Eastern Bloc; nonetheless, it has been criticized by social scientists since the 1970s and 1980s. Alternative models helped to analyze both the system of government and society at large, with the concept of corporatism as a different key to this system. ${ }^{58}$ Corporatism was conceived of as 'a decision making structure in which major functional interest groups are incorporated into the policy processes by the state and its leaders. ${ }^{59}$ It was a system for the representation of interests whose units were aggregated into distinct, compulsory, non-cooperating, hierarchical, and

57 Carl J. Friedrich, Zbigniew Brzeziński, Totalitarian Dictatorship and Autocracy, Boston 1965.

58 Lenard J. Cohen and Jane P. Shapiro, 'Introduction: Communist Systems in Comparative Perspective' in eadem (eds), Communist Systems in Comparative Perspective, New York 1974, pp. XXI-XXXVII.

59 Christopher I. Xenakis, What Happened to the Soviet Union? How and Why American Sovietologists Were Caught by Surprise, Westport, CT 2002, p.106. 
functionally autonomous mass organizations, which were licensed (if not created) by the state, with a recognized monopoly over the social categories in which they operated. ${ }^{60}$

In the post-Thaw communist system, corporatism was the state's answer to the deficit of pluralism, growing complications in the processes of decisionmaking, the need for information and the expansion of the bureaucracy. Mass organizations were important both as bodies that controlled the masses through mechanisms of cooptation, and as substitutes for groups that brought together people with common interests. They enacted a state monopoly over group interests, but simultaneously enabled large numbers of people to participate in the political system. They conditioned those groups to be loyal to the state, in exchange for some consideration of their wishes when decisions were taken on their behalf. Mass organizations therefore depended on a transaction: economic goods (privileges) were exchanged for political goods (including the legitimization of power). As such, these organizations were part of a sui generis communist welfare state. ${ }^{61}$

Three issues are central to the present work. First, the organizations' means of management and their goals were affected by conflicts in the higher echelons of power, in which diverse views and interests were at odds with each other, despite an outer semblance of unity. Second, although the structure of nearly every formal organization in communist Poland was hierarchical, various defence mechanisms operated at each level of the hierarchy, advancing and protecting diverse interests. Individual cells within a given organization could manipulate information in order to influence the actions of higher authorities. Third, organizations developed secondary structures of informal ties parasitic on the organizations' declared formal aims: patron-client relations that manifested concrete goals and strivings, in contrast to the abstractly defined socio-political categories with which the organizations themselves operated. ${ }^{62}$

Non-totalitarian interpretations of the communist system were later also supported by the 'second generation of revisionists'. Following Sheila Fitzpatrick,

60 Valerie Bunce and John M. Echols, 'Pluralism, Corporatism and the Soviet Union' in Susan Gross Solomon (ed.), Pluralism in the Soviet Union: Essays in Honor of H. Gordon Skiiling, New York 1983. See also: Daniel Chirot, 'The Corporatist Model and Socialism', Theory and Society 2, 9 (1980), pp. 363-381.

61 This has been shown for instance by Barbara A. Nowak, whose work on the Women's League in Poland argues that this organization simultaneously served the aims of dictatorship and women's interests. See her Serving Women and the State: The League of Women in Communist Poland. Unpublished doctoral dissertation, Ohio State University, 2004.

62 Winicjusz Narojek, Perspektywy pluralizmu w upaństwowionym społeczeństwie. Ocena sytuacji na podstawie polskich kryzysów, Warszawa 1994 [1986], p. 94; Dariusz Stola, Kampania antysyjonistyczna w Polsce 1967-1968, Warszawa 2000, p. 18, 19. 
they questioned the usefulness of the totalitarian thesis even in relation to the Stalinist period, arguing that Soviet society did not stand by as a passive object of state manipulation. They pointed, for instance, to the mobility of the lower classes, which affected the creation of a new power elite and the legitimation of the system, and to the inability of the communist party to exert total control over society. A large number of scholarly works have appeared that examine local phenomena and the everyday functioning of the Soviet system in the USSR and its dependent countries, with a significant emphasis on understanding people's subjective perceptions of the realities of their time. These studies draw attention to official ideology, but from the perspective of asking to what extent it held sway over the creation of new cultural and social norms. ${ }^{63}$

This short overview does not at all show that the totalitarian model should be discarded; it still retains a heuristic relevance as a Weberian 'ideal type'. The ideological history of this model starting in Cold War also reminds us, however, that our epistemological structures are unstable: they are dependent on the time in which they are constructed. ${ }^{64}$ One of the main contributions of the sociological and political sciences was that they pointed out the clientelistic character of the communist system. These findings cannot be easily refuted. Meanwhile, the significant achievement of the second generation of revisionists was their attempt to apply different (non-totalitarian) theories and models to the interpretation of communist society. These theories, which for example concerned social roles, interactions and socialization, or concepts borrowed from cultural anthropology, have assisted the discovery of new social spaces previously hidden from the scholarly gaze.

It is also worth considering theories about social institutions put forward without overt reference to the communist system. Mary Jo Hatch, for example, has proposed three basic perspectives from which to study organizations: the modern (system-based), symbolic (interpretive) and postmodern. ${ }^{65}$ Of these approaches, the present study adopts a method that is closest to Hatch's symbolic-interpretive perspective. Organization theorists who use this approach, often citing Berger and

63 For instance: Sheila Fitzpatrick, 'Introduction' in Sheila Fitzpatrick (ed.), Stalinism: New Directions, London 2000, pp. 1-14; Stephen Kotkin, Magnetic Mountain. Stalinism as a Civilization, Berkeley 1995, pp. 2-6. For Polish equivalents, see numerous books published in a history series by the 'Trio' publishing house. E.g. Błażej Brzostek, Za progiem. Codzienność w przestrzeni publicznej Warszawy lat 1955-1970, Warszawa 2007; Małgorzata Mazurek, Społeczeństwo kolejki. O doświadczeniach niedoboru 1945-1989, Warszawa 2010.

64 This is demonstrated elegantly by Abbott Gleason's study of the history of the concept of totalitarianism: Totalitarianism: The Inner History of the Cold War, Oxford 1995.

65 Mary Jo Hatch, Organization Theory: Modern, Symbolic, and Postmodern Perspectives, Oxford 1997. 
Luckmann's classic work The Social Construction of Reality, ${ }^{66}$ emphasize that the circumstances, structures, cultures and operations of organizations are the result of social 'negotiations' that accumulate through the course of history. The task of the researcher is therefore to examine the processes by which meanings and symbols are created, as well as their impact on the form of the organization. I believe that adopting such a perspective in a study of communism makes it possible to engage with the findings of earlier studies whilst also avoiding anachronisms in the analysis of the period under consideration. In implementing this approach, I have tried to show how myths about the war in communist Poland were made and then revised through complex and often informal social negotiations within the structures of the mononopolist mass organization.

\section{Sources Consulted}

The published sources consulted in this study include legislative acts (laws and statutes), journals, and bulletins issued by veterans, as well as irregular sources where available. However, archival sources were the principal target of my research. I read hundreds of minutes and shorthands of sessions of the central and local authorities of ZBoWiD. Despite being written in the communist newspeak, these documents contain invaluable descriptions of the goals, activities, and everyday practices of veterans' and former camps' prisoners in Poland. A 'grassroots' perspective is gained through the consultation of available correspondence, minutes and reports from two provinces: Warsaw and Lublin voivodeships (województwa). Warsaw voivodeship practically chose itself as an area to study in detail, because of the importance of the memory of the Warsaw Uprising (1944) and Ghetto Uprising (1943), and the fact that the headquarters of numerous resistance organizations were located in the capital. Lublin voivodeship with its more rural character provided a counterweight to the largely urban memory of Warsaw: various partisan movements were active here; the camps of Majdanek and Sobibór were located in this region; many individuals were deported to Germany as forced labourers; and the first communist government, the Polish Committee for National Liberation (Polski Komitet Wyzwolenia Narodowego, PKWN) had its headquarters in Lublin from 1944 and was active in the recruitment of soldiers for the Moscow-led Polish army. The material from Lublin voivodeship was especially valuable for the micro-level interpretation of the Thaw, i.e. 1956-57.

66 Peter L. Berger and Thomas Luckman, The Social Construction of Reality: A Treatise in the Sociology of Knowledge, Garden City, NY 1966. 
Relevant information was also found in the documents of many other institutions, including the party, army and secret police. The secret police files, now kept in the Institute of National Remembrance (Instytut Pamięci Narodowej, IPN), can be used as a 'corrective' lens against official documentation only to a limited degree. I was astonished by the number of errors and inaccuracies in the facts they present, in terms of both wartime history and the post-war present day (including names, pseudonyms, etc.). More importantly, the secret police (Urzad Bezpieczeństwa, UB; from 1956, Stużba Bezpieczeństwa, SB) did not write 'everything' in their reports; instead, they concentrated on 'enemy' themes. In the period after 1956, these were mostly anti-Soviet or anti-party statements, or those that criticized the SB itself. The reports tended to exaggerate the statements and views of the individuals under surveillance. They contain many accounts of threats by political opponents to 'beat the communists'; yet it is difficult to ascertain the extent to which such threats were actually made, and, on the other hand, the extent to which they were the products of the animosity of the reports' authors. It is interesting, for example, to consider the recurrent formula in reports from after 1956 that concerned the immediate post-war years: 'he had [miat] murder and armed assaultc: does this phrase mean that the individual concerned actually committed these crimes in the past? Or that he only 'had' them in his records, possibly as a result of trumped up charges? Members of ZBoWiD were monitored by the secret police with extra care, because of a fear that an anti-communist resistance movement would re-form under the auspices of the veterans' union. This anxiety also influenced police evaluations of individuals: 'an enemy element of the reactionary type'; 'a bandit element of WiN [Wolność i Niezawistość, an anti-communist organization, 1945-52]; 'formerly bandit element of WiN' (distinguished, it must be said, from the 'common bandit'); and 'member of the former organization of the Home Army' (an 'organization' rather than an army, and a 'former' one: no longer extant and so having no legitimacy). ${ }^{67}$

Furthermore, the secret police reports are also entangled in the internal conflicts within the Ministry of Internal Affairs. Reports from the Third Department of the Ministry, overseen by deputy minister Antoni Alster, make up the majority of materials of this kind dating from the late 1950s and the early 1960s and used in this book. Alster was in conflict with another deputy interior minister, Mieczysław Moczar, who was at this time seeking accords with selected members of the Home Army, including former partisans who had supported the anti-communist underground movement in the early post-war years. Moczar was becoming increasingly popular among lower- and mid-level officers of the Security Service. Alster, meanwhile, had emphasized at a gathering of ministry functionaries in

67 On the Home Army (Amia Krajowa, AK), WiN and other organizations mentioned in this section see explanatory footnotes in Chapter 2. 
1957 that the fight against the anti-communist underground had been 'our holy and righteous deed' ${ }^{68}$ and there were a number of officials in the Third Department who had begun to doubt Alster's policies. For example, a negative opinion about Bolesław Kukiełka, one of former commanders of the anti-communist Peasants' Battalions (Bataliony Chłopskie, BCh), voiced by an official from Lublin, was met with disapproval by a senior officer of the Third Department in Warsaw:

It seems to me that comrades who continue to see Kukiełka as a bandit are, to a certain extent, being overly impressionable on this point. And moreover, I cannot help thinking that their point is to show that they are capable of grinding down an individual like Kukiełka. Personally, I see no grounds for the expulsion of [Kukiełka] from ZBoWiD, nor for his demotion from his current post within the organization. ${ }^{69}$

In the provinces, a UB/SB functionary was sometimes faced with the very real inconvenience of having to put up with a neighbour who had returned from prison as the result of an amnesty. Reports filed by such officials may have been coloured by personal biases and vendettas. Finally, the role of alcohol must not be neglected in the critical reading of these sources: the most flamboyant statements made by veterans under surveillance were often uttered during meetings between highly inebriated comrades, and then recorded by Interior Ministry informers. ${ }^{70}$ Materials from the Ministry of Internal Affairs, therefore, illustrate above all the prevailing atmosphere within the secret police, which is important for this study, especially given that the Security Service not only influenced disputes over Second World War memory in Poland, but was also internally divided.

Significantly, in secret police files, I did not find many details about memory groups other than the Home Army, of which there were many - including demobilized soldiers, former PoWs, prisoners of concentration camps, and smaller but important (because of their closeness to state power) groups such as partisans of the People's Army (Armia Ludowa, AL), participants of the Spanish civil war and communist veterans of the revolutions of 1905 and 1917. For this reason, I do not show in equal detail the problems and polemics surrounding these groups. The focus of this study remains on the memory conflicts concerning the Home Army and anti-communist underground, as well as on the various consequences of the inclusion of concentration camp victims into the veterans' union. This bias

68 'Dyskusja podczas narady krajowej [MSW]', 14-15 February 1957, cited in Krzysztof Lesiakowski, Mieczysław Moczar 'Mietek'. Biografia polityczna, Warszawa 1998, p. 197.

69 'Notatka służbowa dot[ycząca] Kukiełki Bolesława s[yna] Stanisława b[yłego] d[owódcy] oddziału lotnego BCh z powiatu Krasnystaw woj. Lublin', Warsaw, 20 October 1959, AIPN, 00231/176/vol. 2, p. 252.

70 For instance, 'Notatka informacyjna dot[ycząca] działalności elementów byłego podziemia AK WiN, NSZ, grup bandyckich i peeselowskich na bazie ZBoWiD’, Lublin, 17 April 1957, AIPN, 00231/182/vol. 1, p. 63. 
is in keeping with the overall aims of the book: the issues surrounding the Home Army, the underground, and the camps were a significant and constitutive part of the changes that affected the ideological shifts of the 1956 Thaw and of 1967-68 in Poland. These were conflicts about the legitimacy of the system of power, so other fields of memory were of secondary importance.

Last but not least, I also recorded oral history interviews with fifteen former members of ZBoWiD. In the process of drawing up a list of interviewees, I tried to ensure that different military and camp groupings were represented and that my informers came from different rungs of the organizational hierarchy. These were semi-structured conversations about the war experience, circumstances of joining veteran associations, and the activities carried out in ZBoWiD. It is only thanks to these conversations that I have been able to notice certain recurring but hidden themes in the written sources. They included: the importance of social matters to the groups under study (whereas the archival sources suggested primarily ideological concerns), and the prevalence of informal ties over the formal organization. This helped me to develop a more corporatist explanation of how ideology was put into practice in the 1960 s, and to conceptualize more clearly how the memory of war was negotiated in Poland, despite the restrictions imposed by communist dictatorship. 


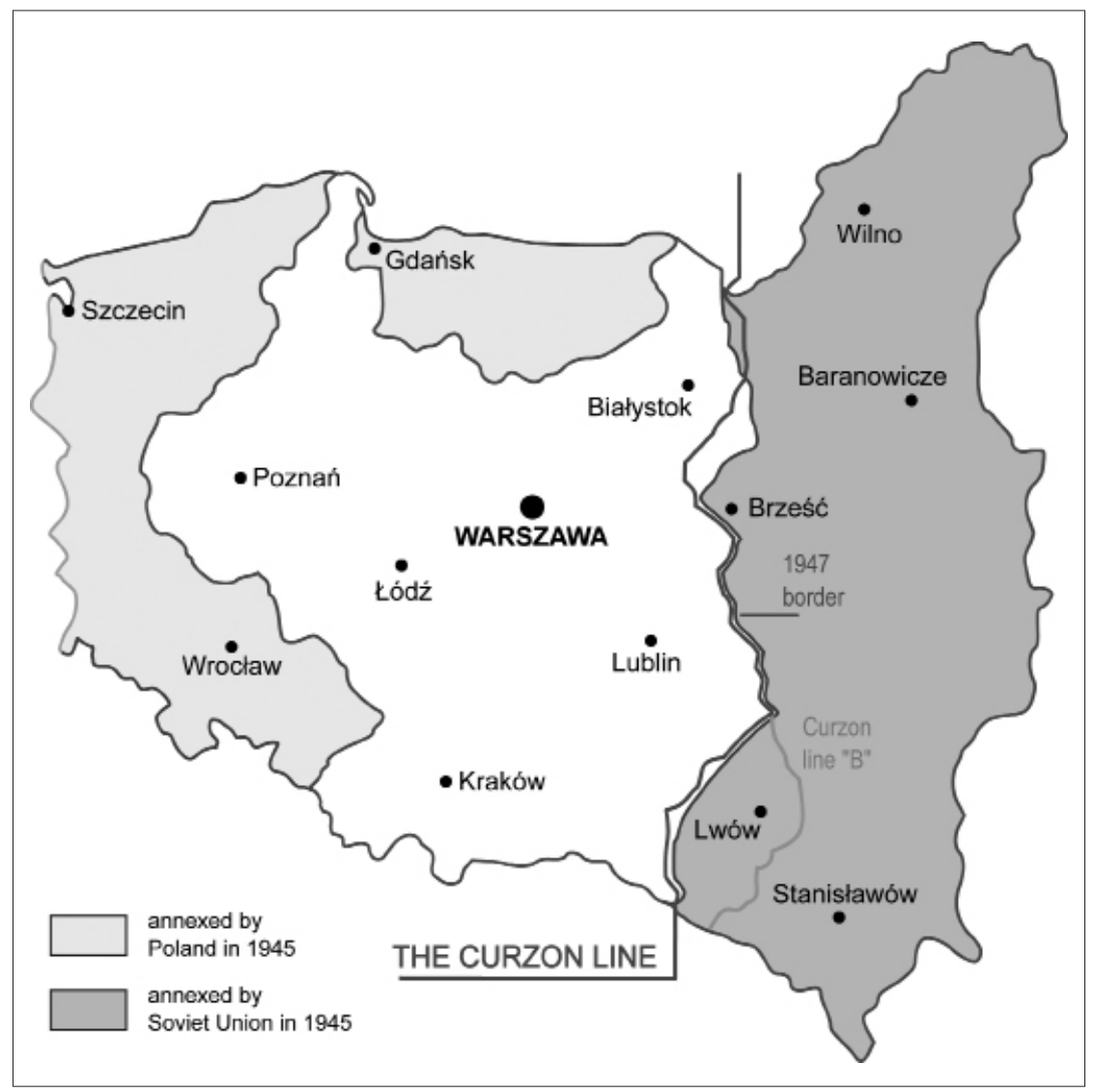

2.1 Map of post-war shifts of borders. Wikimedia Commons. 


\section{Chapter 2 \\ The Communist Post-war: Organizing Life and Memory}

\section{Challenges of Demobilization}

Between 1944 and 1948, a new political system was imposed on Poland. The results of a national referendum and parliamentary elections ${ }^{1}$ were falsified, and communist activists engaged in violence rather than vying for social support. However, having mainly terror at their disposal, the communists found themselves in a difficult situation. On the one hand, the whole of society was characterized by a high degree of anomie, the breakdown of social bonds, the effects of the destructive policies of two occupying powers and the wartime experience of 'not quite living' (zycie na niby). ${ }^{2}$ On the other hand, various groups, including the armed antiSoviet resistance, possessed social capital gained during the course of the war and directed against the communists. ${ }^{3}$ Moreover, Ukrainians were fighting for their

1 In June 1946, the communists held a general referendum testing their support in Poland, campaigning for three 'yes' answers to the following questions: (1) Are you in favour of abolishing the Senate? (2) Are you in favour of agricultural reform and the nationalization of key industries? (3) Are you in favour of the new western border? The non-communist democratic forces encouraged voters to answer 'no' to the first question. The results were forged in the communists' favour. Following the referendum, the Allies called for democratic elections, which were carried out in 1947 and also manipulated, giving the socalled democratic bloc, dominated by the Polish Workers' Party (PPR), $80 \%$ of the vote and a majority of seats in parliament. See: Jerzy Drygalski and Jacek Kwaśniewski, 'No-Choice Elections', Soviet Studies 2, 42 (1990), pp. 295-315; Krystyna Kersten, The Establishment of Communist Rule in Poland, 1943-1948, Stanford 1991; Michał Skoczylas, Wybory do Sejmu Ustawodawczego z 19 stycznia 1947 roku w świetle skarg ludności, Warszawa 2003.

2 Kazimierz Wyka, Życie na niby, Kraków 1984; see also Jan T. Gross, 'Geneza społeczna demokracji ludowych. O konsekwencjach II wojny światowej w Europie Środkowej’ in Tomasz Szarota (ed.), Komunizm. Ideologia, system, ludzie, Warszawa 2001, pp. 40-58; Marcin Zaremba, Wielka Trwoga. Polska 1944-1947. Ludowa reakcja na kryzys, Kraków 2012.

3 The Home Amy (Armia Krajowa, AK) was the main Polish anti-German underground resistance movement during the war; it was formed in 1942 from its predecessor Zwiazek Walki Zbrojnej (Union of Armed Struggle, ZWZ). It kept its close ties with the Polish 
independence in the south-east of the country, and the stability of Poland's new western border was constantly being questioned. ${ }^{4}$ Red Army units stationed in the west and north of the country were stripping bare the formerly German territories which had just been ceded to Poland, and which were supposed to play a major role in the legitimization of the new communist government. Infrastructure destroyed by the war posed problems for large-scale forced evacuations and resettlement initiatives, and also for spontaneous migration by citizens.

In any country which has recently experienced war, the reconstruction of the political, economic and social institutions needed by peacetime society is a difficult task; the structures of war must be dismantled at the same time, which involves the enormous logistical enterprise of mass demobilization. No government wants competition, and as it strives for a monopoly over the means of violence, it understandably becomes wary of individuals and groups who are capable of wielding weapons. In Poland, demobilization was carried out under such conditions that many soldiers could not return to their homes, because those homes had either been destroyed or were now in the territory that had become part of the USSR. Partisans also had to be 'demobilized', a separate and more complex problem, given that they had never been subject to direct government control. Even in Western Europe, where the scale of the resistance was smaller, the post-war years witnessed conflicts between the bureaucracy of the new civil apparatus and former participants of the wartime underground; 5 in Poland, the communists faced the task of liquidating

government-in-exile in London and was often conflicted with communist forces. In January 1945, the Home Army was officially disbanded, the communist government asked its members to come out, guaranteeing their safety. Many of those who obeyed were imprisoned, executed, or deported into the Gulag. As a result, some AK members formed covert Freedom and Independence (Wolność i Niezawistość, WiN) among other organizations. They carried out attacks on both Soviet and Polish communist institutions. In return, the communist authorities pursued mass arrests, deportations and executions. Today, post-war anti-communist resistance is known as the 'cursed soldiers' (zotnierze wyklęci). Their memory is controversial, as some of the groupings were engaged in the post-Holocaust anti-Jewish violence. On those and other aspects of civil war in Poland, see e.g.: Anita J. Prażmowska, Civil War in Poland 1942-1948, Basingstoke 2004.

4 The Polish border on the rivers of Oder (Odra) and Neisse (Nysa) was agreed at the Yalta and Potsdam conferences in 1945. The border was compensation to Poland at the expense of Germany for territories lost to the Soviet Union as a consequence of the MolotovRibbentrop Pact (1939), and resulted in westward transfers of Germans, matching the Polish population transfers from the East. The border was recognized by East Germany in the Treaty of Zgorzelec in 1950, however, by West Germany only in 1970 in the Treaty of Warsaw. The feeling of uncertainty of this border was overwhelming in Poland until 1956.

5 For instance, István Deák, 'Introduction' in István Deák, Jan T. Gross, and Tony Judt, p. 10, 11; Peter Romijn, Restoration of Confidence: The Purge of Local Government in the Netherlands As a Problem of Postwar Reconstruction', in ibid., pp. 173-193. 
the remains of the Polish Underground State, ${ }^{6}$ which was hostile to their ambitions. Thus, similarly to Yugoslavia and Greece at this time, Poland posed a specific and complex problem for those who sought to govern the country.

Employing the terminology coined by the sociologist Michael Mann, one can say that in the early post-war years in Poland the rulers primarily had recourse to 'despotic power', i.e. they could take decisions and exert violence without any consultation with society. However, their 'infrastructural power' was weak: there was a shortage of institutions and administrative structures that would enable them to control and monitor the governed. ${ }^{7}$ Regaining infrastructural power amidst post-war chaos and the brutalization of everyday life, devastating poverty and widespread social hostility to government - was one of the most important challenges of the time.

In this light, the emergence of veterans' organizations appears as an attempt to reconfigure the mechanism of power from a wartime to a peacetime model, by channelling and ordering a large and unwieldy mass of human potential; it was effectively a means of dismantling the war apparatus of violence. A former underground fighter who functions within the framework of a veterans' union is predictable: he has made public his activities of the recent past, and laid down his arms. A soldier who 'sows and ploughs' (propaganda at this time encouraged former soldiers to settle into agricultural lifestyles) is constantly occupied; when he comes to a union meeting, he is being monitored and can be deployed for the creation of symbolic capital for the rulers.

Still, the first post-war years were not only characterized by the strengthening of the power of the Polish Workers' Party. This was also a time of harsh everyday realities: burying the dead, attempting to provide assistance to orphaned children, the injured and sick. ${ }^{8}$ Millions had died ${ }^{9}$ and thousands had partially or completely

6 The Polish Underground State or Polish Secret State (Polskie Państwo Podziemne) is a catchall term for the covert resistance organizations, both military and civilian, that were active in Poland during World War II and were faithful to the Government of the Republic of Poland in exile in London. Militarily, it relied above all on various branches of the Home Army.

7 Michael Mann, The Sources of Social Power: the Rise of Classes and Nation-States, 17601914, Cambridge 1993, p. 59.

8 Common ailments included neurosis, tuberculosis, heart disease, rheumatism and venereal disease.

9 The population now counted approximately 24 million, i.e. around ten million less than at the outbreak of the war. The sharp decline was a result of warfare, the Holocaust, mass murders of non-Jewish Poles, changes to the national borders, migration (including decisions by some Poles to stay in exile in the West), and forced expulsions of ethnic Germans and Ukrainians from Poland. Most of the deaths were caused by the racist policies of Nazi Germany. The number of Slavic victims was inflated by the Polish communist state. It is now generally accepted that between 5.5 and 6 million Polish citizens died as a result of the German 
lost their ability to work. Polish historian Robert Traba calls this period an era of 'live memory' (żywa pamięć), a term that captures the proximity in time and place of the war and the emotional involvement of the society in the process of commemoration; the term also points to the fact that the state had not yet established a total monopoly over public space. ${ }^{10}$ Political parties and the Catholic Church were advancing their often disparate interpretations of recent events. The press was full of war-related themes. Nazi war criminals were put on trial. Several institutions were founded that would go on to have a profound significance for memory culture in Poland, including the Main Commission for Research into German Crimes in Poland (1945) ${ }^{11}$ and the Council for the Protection of Sites of Struggle and Martyrdom (1947). ${ }^{12}$ The first laws were passed that delimited the scope of assistance available to different segments of the population, in accordance with their specific experience of war.

occupation in Poland, including over 3 million Polish Jews. The number of Polish victims of the various forms of Soviet repression (deportation, the Gulag, prisons) is still unknown. It is believed that over 1.5 million people were affected. So far, only 10 percent of those have been documented as fatalities because of the scarcity of sources. Many Poles who remained in the east as a result of Soviet repression were repatriated to Poland only after 1956.

See Adam Eberhardt et al., 'Szkody wyrządzone Polsce podczas II wojny światowej przez agresora niemieckiego. Historia dociekań i szacunków' in Witold M. Góralski(ed.), Problem reperacji, odszkodowań i świadczeń w stosunkach polsko-niemieckich, 1944-2004, vol. 1, Warszawa 2004, pp. 11-54; Mateusz Gniazdowski, 'Zu den Menschenverlusten, die Polen während des Zweiten Weltkrieges von den Deutschen zugefügt wurden. Eine Geschichte von Forschungen und Schätzungen', Historie. Jahrbuch des Zentrums für Historische Forschung Berlin der Polnischen Akademie der Wissenschaften, 1 (2007/2008), pp. 65-92; Wojciech Materski and Tomasz Szarota (eds), Polska 1939-1945. Straty osobowe i ofiary represji pod dwiema okupacjami, Warszawa 2009; Małgorzata Ruchniewicz, Repatriacja ludności polskiej z ZSRR w latach 1955-59, Warszawa 2000.

10 Robert Traba, 'Symbole pamięci: II wojna światowa w świadomości zbiorowej Polaków. Szkic do tematu', Przeglad Zachodni 1, 56 (2000), p. 54; Zofia Wóycicka, 'Die Kanalisierung des Gedenkens: Die Gedenkstätte Auschwitz-Birkenau in den Jahren 19451955' in Stefan Troebst and Krzysztof Ruchniewicz (eds), Diktaturenbewältigung und nationale Selbstvergewisserung - Geschichtskulturen in Polen und Spanien im Vergleich, Wrocław 2004, pp. 183f.

11 This body was founded as the Main Commission for Research into German Crimes in Poland (Główna Komisja Badania Zbrodni Niemieckich w Polsce). In subsequent years, its name was modified in line with changes in the political agenda. In 1949 it was transformed into the Main Commission for Research into Hitlerite Crimes in Poland (1949-84), and in 1984 renamed as the Main Commission for Research into Hitlerite Crimes in Poland Institute of National Remembrance (1984-91). It functions to this day as the Commission for the Prosecution of Crimes against the Polish Nation, which is a branch of the Institute of National Remembrance.

12 Rada Ochrony Pamięci Walk i Męczeństwa. 
The available data on the number of the potential applicants for assistance from the state in returning to normalcy, and on the related number of people who survived the war, are only estimates. Nonetheless, they point to a large-scale social problem. As of the end of the war, there were a little over 330,000 soldiers fighting in the Polish Armed Forces in alliance with the Red Army. ${ }^{13}$ Between 1945 and 1946, approximately 200,000 of them were demobilized. ${ }^{14}$ The Polish Armed Forces in the West had nearly 230,000 soldiers in July 1945; 105,000 decided to return to Poland. ${ }^{15}$ Moreover, there were around 132,000 liberated Polish PoWs in the German territories occupied by the western Allies; it is not known how many of them decided to be repatriated to Poland. ${ }^{16}$ Establishing the number of people

13 Troops were chiefly recruited from those Polish prisoners in Soviet labour camps who had not managed to join the army of Władysław Anders, founded earlier as a result of the Sikorski-Mayski agreement (1941). The soldiers taken earlier by Władysław Anders to Iran had fought along the Western Allies, and the so-called Polish Armed Forces in the West were a taboo in the 1950s in communist Poland. Only the story of the socalled Zygmunt Berling's army, therefore, could be told (without overt reference to the circumstances of its formation), and it grew into a myth of victorious battles from Lenino (1943) to Berlin (1945). Czesław Grzelak, Henryk Stańczyk and Stefan Zwoliński, Armia Berlinga i Żymierskiego. Wojsko Polskie na froncie wschodnim, Warszawa 2002, p. 97. On the Polish Armed Forces in the East see also recent oral history study: Mateusz Czapigo (ed.), Berlingowcy. Żotnierze tragiczni, Warszawa 2015.

14 Kazimierz Frontczak, Sity zbrojne Polski Ludowej. Przejście na stope pokojowa 19451947, Warszawa 1974, p. 273f; Jerzy Kajetanowicz, Polskie wojska ladowe w latach 1945-1960. Skład bojowy, struktury organizacyjne i uzbrojenie, Wrocław 2002, p. 27, 34

15 Jerzy Radomski, 'Losy formacji polskich na Zachodzie po zakończeniu wojny' in Witold Biegański (ed.), Walki formacji polskich na Zachodzie, 1939-1945, Warszawa 1981, p. 746. On the decision faced by former Polish soldiers whether to return to Poland or to stay away from the communist regime, see the excellent microhistories provided by two books on the fates of members of the Polish First Armoured Division of the Polish Armed Forces in the West: Machteld Venken, Straddling the Iron Curtain? Immigrants, Immigrant Organisations, War Memories, Frankfurt am Main 2011; Jarosław Pałka, Machteld Venken and Krzysztof Marcin Zalewski, Żotnierze generała Maczka. Doświadczenie i pamięć wojny, Gdańsk 2013. On the history of Polish veteran movement in exile, see the recent study: Piotr Kardela, Stowarzyszenie Polskich Kombatantów w Stanach Zjednoczonych w latach 1953-1990, Olsztyn 2015.

16 Danuta Kisielewicz, Oficerowie polscy w niewoli niemieckiej w czasie II wojny światowej, Opole 1998, p. 277. Approximately 420,000 Polish soldiers entered German captivity as a result of the military operations of 1939, including around 18,000 officers. The number of soldiers captured by the Red Army in 1939 is estimated to be about 180,000, including over 15,000 officers who were later executed at Katyn and other killing fields. The majority of the regular soldiers were set free, some were exchanged for prisoners held by the Germans, and others were recruited into the Red Army. The PoWs in Germany were later joined by soldiers of the Polish Armed Forces in the West (Polish soldiers who were captured during 
who took part in the partisan movement and civilian conspiracy in Poland (within the structures of the Polish Underground State as well as independently of it) is a more difficult task: it is usually estimated that around a million people were involved, although the contribution by many individuals was minor. The Home Army numbered 250,000 to 300,000 people at the peak of its organized activity, in spring 1944; however, there was sufficient weaponry for only 30,000 fighters (the loss of life, chiefly during the Operation Tempest and Warsaw Uprising ${ }^{17}$ is estimated at several tens of thousands). The Peasants' Battalions (BCh), ${ }^{18}$ the rightwing National Armed Forces (NSZ) ${ }^{19}$ the communist People's Guard (GL - later the People's Army, AL) ${ }^{20}$ and other local organizations in most cases remained outside the command structure of the AK. As we will see, the legacy of the Home

battles with France and Britain, who were recorded as French and British PoWs), as well as by an undetermined number of soldiers captured during Hitler's advance on the USSR and by insurgents of the 1944 Warsaw Uprising. In 1940-42 many regular soldiers and sub-officers were freed - their status was however often changed to that of civilians who carried out forced labour in Germany. The mortality of the PoWs is unknown. Danuta Kisielewicz, passim.

17 Operation Tempest (Akcja Burza) was a series of anti-German uprisings by the Home Army in 1944 in Eastern and Central Poland. It was aimed at taking hold of cities and areas occupied by the Nazis while they were preparing their defences against the approaching Red Army, and at securing Polish power before the arrival of the Soviets. The Operation was largely unsuccessful; the biggest failure of this plan was the Warsaw Uprising, after whose failure the city was destroyed by the German forces.

18 The Peasants' Battalions (Bataliony Chtopskie) were created in the mid-1940s and by 1944 were partially integrated with the Home Army. The major actions of their armed resistance took place in the rural Zamość area which was chosen for German colonization as part of Generalplan Ost.

19 The National Armed Forces (Narodowe Sity Zbrojne) were created in 1942 and fought against both the Nazi and Soviet forces. They were likewise engaged in fighting Polish communists during and after the war. In the aftermath of war they were persecuted by the communist authorities. Not until 1992 were they rehabilitated and given the official status of war veterans, receiving pensions and decorations. The polemics around their history are close to those concerning WiN members because of post-war anti-Jewish violence. (See footnote 3 of this Chapter).

20 The People's Guard (Gwardia Ludowa, GL) was a communist resistance organization created in 1942. It was later renamed as the People's Army (Armia Ludowa, AL). The number of soldiers was inflated by the post-war communist authorities for propaganda purposes. Ryszard Nazarewicz, the principal historian of the AL in communist times, revised his earlier figures after 1989, stating that the AL had around 54,000 members when the Red Army re-entered Polish territory, around 8,000 of whom fought in partisan formations. These figures could still contain inaccuracies. Ryszard Nazarewicz, Armii Ludowej dramaty i dylematy, Warszawa 2000, p. 250, 251. See also: Piotr Gontarczyk, Polska Partia Robotnicza. Droga do władzy 1941-1944, Warszawa 2013. 
Army became the most sensitive issue in the following years and the most important reference point for the narratives of the state and other partisan groups.

However, communist memory practice was peculiar in that it merged armed fighters with civilian victims. Still, establishing the number of people who survived hardships as a result of war is even more difficult. It is believed that about 350,000 Polish Jews survived the Holocaust, most of them in Soviet territory. Many of them immediately left Poland on their way to the West and to Palestine, not least because of post-war anti-Jewish violence. By 1947, only around 90,000 remained in the country. ${ }^{21}$ It is also estimated that several hundred thousand non-Jewish Polish citizens who were interned in Nazi camps and prisons of various types survived to tell the tale. They became one of the most active victims' memory groups in later years. Against this background, it is good to keep in mind that more than two million citizens of the inter-war Poland were sent to Germany as various kinds of forced labourers (in camps, industry, agriculture); the amount of time spent in exile could vary from several weeks to years. It is not known how many of these labourers survived. Czesław Łuczak estimates that over 1.5 million individuals had returned to Poland by 1949 and around 350,000 had refused repatriation..$^{22}$ However, former labourers' memories, alongside their claims to state assistance, would be overshadowed for years by other memory issues.

\section{Communist Legislation and the ex-Combatants and Prisoners, 1945-48: A View From Above}

The institutionalization of the veterans' and political prisoners' movements in the early post-war years can be considered from two perspectives: from above and from below. The former entails understanding the priorities set by the party authorities (aimed at maintaining their recently gained power and ensuring the country's governability as a communist state), while the latter involves the study of the expectations of individuals and groups who survived the war and now found themselves in a new socio-political reality. Indeed, the first laws regulating the rights and privileges of victims and veterans were passed at roughly the same time that the first grassroots commemorative groups and unions were formed; the two

21 See for instance: Michael C. Steinlauf, Bondage to the Dead: Poland and the Memory of the Holocaust, Syracuse, N.Y 1997; Grzegorz Berendt, August Grabski and Albert Stankowski, Studia z historii Żydów w Polsce po 1945 roku, Warszawa, 2000; Jan T. Gross, Fear: Anti-Semitism in Poland after Auschwitz, Princeton 2006.

22 Czesław Łuczak, Polacy w okupowanych Niemczech, Poznań 1993, p. 39. 
vectors of memory were in dynamic relation to each other, with the politicians reacting to the initiative of the masses and vice versa.

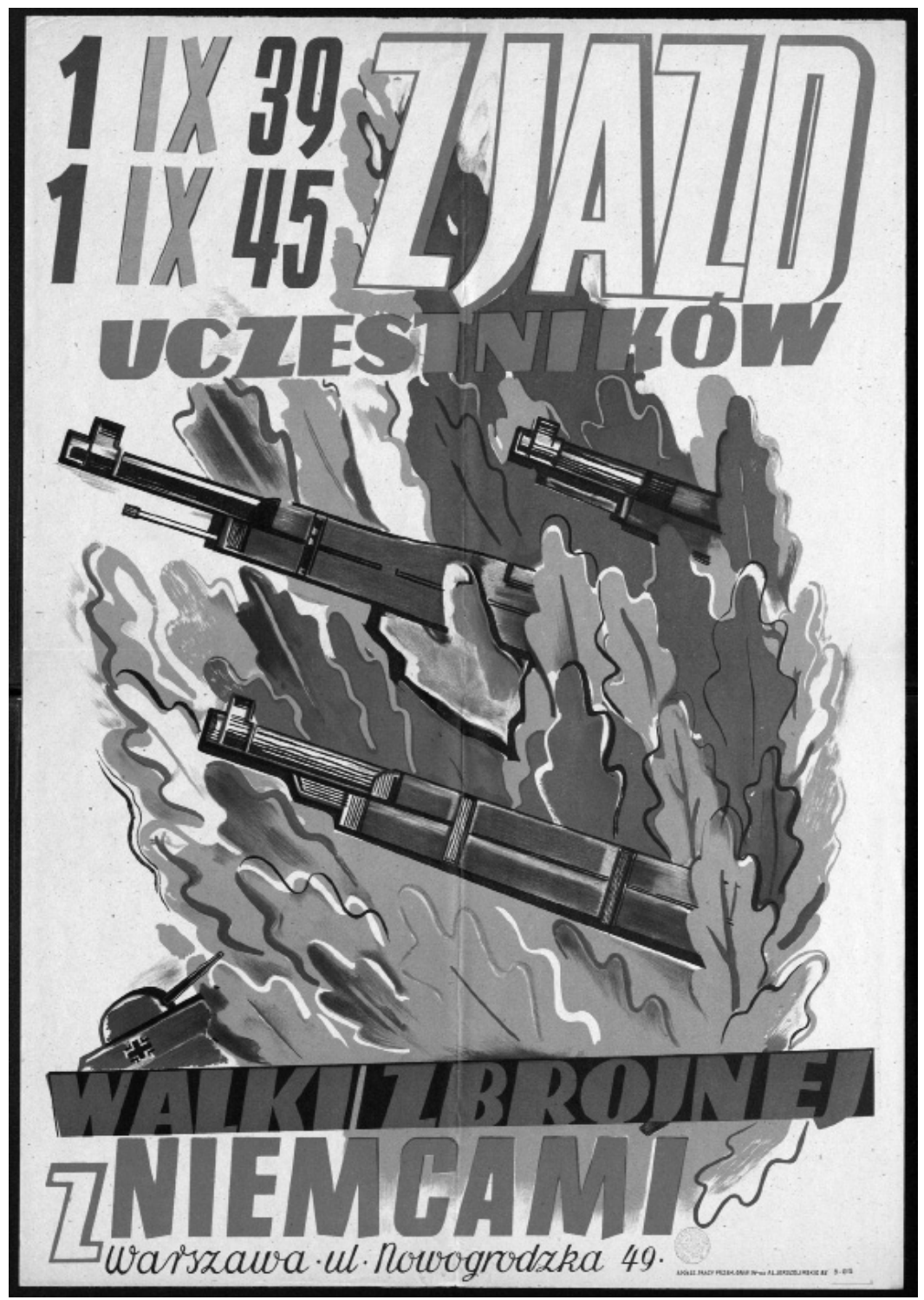

2.2 Poster of the Congress of ZUWZoNiD in Warsaw, 1945. National Library of Poland. 
Scholars tend to eschew consideration of legal regulations in their studies of communist Poland, but the introduction of laws and various attempts to adapt prewar legal norms to the post-war situation were an essential indicator of a change in attitudes. First, there was a need to redefine the legal category of veterans. ${ }^{23}$ The provisions of pre-war legislation, which mainly covered soldiers of the Great War and the Polish-Soviet War (1919-21) with some additional privileges for participants of national uprisings and political prisoners of Prussia and Russia, were no longer sufficient in the new situation. Now, it was necessary to make concessions to members of the civilian conspiracy, partisans, and hundreds of thousands of victims of racial persecution. Second, new laws were also symptoms of political conflicts. The first provisions concerning the rights of partisans were passed in 1944. A December decree of the Polish Committee for National Liberation (Polski Komitet Wyzwolenia Narodowego) introduced changes to the pre-war welfare provisions for war invalids (which, until then, had reserved privileges for regular soldiers): it expanded the categories of person eligible for monetary pensions, state benefits and state-sponsored healthcare, and established co-operatives for the participants of 'underground and partisan anti-fascist military organizations formed after 1 September 1939. ${ }^{24}$ In 1947, the legislature made a further step towards the empowerment of communist partisans, by adding to the ranks of ex-combatants those Poles who fought in 'military anti-fascist

23 The Polish term for a 'veteran', kombatant, changed in meaning precisely as a result of post-war memory politics. Before the war, it had a similar semantic scope to the French word on which it was based, combattant: 'a soldier engaging in combat, a fighter'; 'one who engages in a duel with another'. In other words, the word designated a soldier and not a veteran (Jan Karłowicz (ed.), Słownik języka polskiego, Warszawa 1902, p. 416). As a result of communist memory practice, the term came to mean a 'former soldier of a regular military formation, a former member of a partisan division who actively participated in battle, a former participant of a resistance movement, a former political prisoner' (Halina Zgółkowa (ed.), Praktyczny słownik współczesnej polszczyzny, Poznań 1998, p. 10).

24 'Dekret Polskiego Komitetu Wyzwolenia Narodowego z 12 grudnia 1944 o zmianie ustawy o zaopatrzeniu inwalidzkim' Dz.U. nr 15, poz. 81. [N.B. 'Dz.U.' refers to Dziennik Ustaw, the Journal of Laws of the Republic of Poland. References to this source conventionally give an issue number for the year in question ('nr'), and the 'position' (poz.) within the volume of the statute in question; the latter does not correspond to a page number. All of these texts can be accessed individually online, at http://dokumenty.rcl.gov.pl/.] See, for later changes: 'Ujednolicony tekst ustawy z 17 marca 1932 o zaopatrzeniu inwalidzkim. Załącznik do obwieszczenia Ministra Pracy i Opieki Społecznej z 7 czerwca 1945', Dz.U. nr 22, poz. 22; 'Ustawa z 7 kwietnia 1949 o zmianie ustawy o zaopatrzeniu inwalidzkim', Dz.U. nr 25, poz. 182; 'Ustawa z 23 lipca 1945 o zmianie ustawy o zaopatrzeniu inwalidzkim', Dz.U. nr 30, poz. 181; 'Dekret z 8 listopada 1946', Dz.U. nr 64, poz. 340; and 'Dekret z 25 października 1948 o zmianie ustawy z 17 marca 1932 o zaopatrzeniu inwalidzkim’, Dz.U. nr 56, poz. 387. 
organization in the Spanish civil war between 1936 and 1939' and those who were part of 'Yugoslavian partisan units under [Josip] Tito'. ${ }^{25}$

In 1945, a law was passed that regulated assistance for the family members of deceased partisans and 'participants of the underground movement' - this act primarily concerned their widows and children. Entitlements included a special pension, free healthcare, and additional exemptions for those who chose to settle in the formerly German borderlands. ${ }^{26}$ Soon after, the widows and orphans of 'victims of the enemies of democratic Poland' became eligible for these same benefits. ${ }^{27}$ This decree did not specify what was meant by the terms 'victims' or 'enemies', but it was nonetheless a clear attempt to ensure the loyalty of individuals employed in the state apparatus of power who were fighting against the anti-Communist underground at this time; similar purpose was served by a decree announced in February 1947 concerning 'damages for officials of the Public Security Service, soldiers of the Polish Armed Forces and members of the Civic Militia (Milicja Obywatelska, MO) ${ }^{28}$ who, during the struggle against the enemies of Democratic Poland, have lost their ability to work. ${ }^{29}$ Other important laws that concerned former combatants included a series of decrees made in 1944 and 1945 on military decorations,${ }^{30}$ as well as legislation regulating the demobilization of soldiers - these determined the payouts made to soldiers and

25 'Ustawa z 3 czerwca 1947 o zmianie ustawy o zaopatrzeniu inwalidzkim', Dz.U. nr 43, poz. 226.

26 'Ustawa z 23 lipca 1945 o zasiłkach i pomocy dla osób pozostałych po uczestnikach ruchu podziemnego i partyzanckiego, poległych w walce o wyzwolenie Polski spod najazdu hitlerowskiego', Dz.U. nr 30, poz. 180. See also: Dz.U. nr 55, poz. 434 and 442; Dz.U. nr 65, poz. 528 .

27 'Dekret z 13 listopada 1945 o zasiłkach i pomocy dla wdów i sierot po ofiarach wrogów demokratycznego ustroju Polski', Dz.U. nr 51, poz. 294; 'Rozporządzenie Ministra Pracy i Opieki Społecznej z 17 stycznia 1946', Dz.U. nr 7, poz. 61; and the full text of the decree of 23 November 1945, Dz.U. nr 28, poz. 121.

28 Milicja Obywatelska was a police institution created in 1944 by Polish Committee for National Liberation, replacing the pre-war police force. In 1990 it was renamed back into policja. Contrary to implied meaning of milicja (as a military force composed of ordinary citizens), it was a state-controlled force, often used to exert repressions on the citizens.

29 'Dekret z 3 lutego 1947', Dz.U. nr 14, poz. 54.

30 'Dekret Polskiego Komitetu Wyzwolenia Narodowego z 22 grudnia 1944 o orderach, odznaczeniach i medalach', Dz.U.nr 12, poz. 91. This decree approved the medal 'Honoured for Deeds on the Field of Glory' (Zastużonym na Polu Chwaty), which had been introduced by the high command of the Tadeusz Kościuszko Infantry Division that fought alongside the Red Army, as well as the 'Grunwald Cross' that was introduced by the commanders of the People's Guard. Recipients of the Grunwald Cross enjoyed the same privileges as those who had earned the Virtuti Militari, the oldest military honour in Poland, established in 1792 during the Polish-Russian war. See also: Dz.U., nr 50, poz. 285 (from 26 October 
also, by tying payments to the decision to become a military settler, encouraged soldiers to move to the formerly German regions. ${ }^{31}$

Meanwhile, the laws concerning former concentration camp prisoners remained modelled on the pre-war provisions, which had been developed in relation to former Polish political convicts in Tsarist Russia; thus, they pointed to a certain inertia in law-making, or rather, to an ongoing reliance on pre-war norms, despite the changes in the system of government. Like former prisoners in the pre-war period, wartime concentration camp inmates were entitled to a modest allowance and state-sponsored healthcare. These provisions were, however, outdated: the Siberian penal colonies of Tsarist times were hardly comparable to the extremities of life in German concentration camps. ${ }^{32}$

In a country ravaged and impoverished by war, all of these legal provisions could not solve the everyday problems. The decrees were short-term measures: some were set to expire a year after the cessation of hostilities, while others were temporary solutions designed to be superseded by new regulations. Thousands of eligible individuals did not apply for the benefits in the time given because they had not heard of them, whereas others did not do so because health complications caused by war were diagnosed with a delay ${ }^{33}$ At the time, veterans' privileges were not conferred to members of the civilian resistance (who in some cases had been tortured by the Gestapo), but only to the families of the deceased. The relatives of people who had received court sentences after 22 July $1944^{34}$ were also excluded from the benefits; among these were, of course, members of anti-communist groups, many of whom had previously fought against the Germans. Needless to say, the victims of Soviet repressions were not recognized either. In later years, after the Thaw of 1956, these shortcomings would put the government under strong pressure, leading to significant changes in the scope of privileges. However, it was only in 1975 that a comprehensive package of regulations appeared that clearly defined the

1945, entitled 'Medal za Odrę, Nysę, Bałtyk'), poz. 286 ('Medal Zwycięstwa i Wolności 1945 r.'), poz. 287 ('Medal za Warszawę') and poz. 288 ('Krzyż Partyzancki').

31 See for instance 'Dekret z 18 lipca 1945 o pomocy i zasiłkach dla rodzin żołnierzy Wojska Polskiego oraz zdemobilizowanych żołnierzy’, Dz.U. nr 34, poz. 202.

32 'Dekret z 5 kwietnia 1946 o dodatku przejściowym do zaopatrzeń byłych skazańców politycznych', Dz.U. nr 14, poz. 101. A decree issued in July of the same year established a deadline for the filing of claims: 30 June 1947. See 'Dekret z 1 lipca 1946 o zmianie niektórych przepisów, dotyczących zaopatrzenia byłych skazańców politycznych’, Dz.U. nr 37, poz. 228. Also see: Dz.U. nr 73, poz. 397.

33 Interview with I.G., May 2005.

34 The official day of the proclamation of the Manifesto of the Polish Committee for National Liberation by the Polish communists. It declared the Polish government-in-exile in London to be illegal and proclaimed the authority of the PKWN to extend over all Polish territory. 
rights of veterans and former prisoners, ${ }^{35}$ and debates continue to this day about the eligibility of different groups and the rightful proportions of the provisions.

In the late 1940s, however, the law offered room for 'organizations assisting population groups that were specifically persecuted by the occupier. ${ }^{36}$ Excombatants' and prisoners' self-organization was important precisely because legal provisions were restrictive. It is difficult to compile a complete list of associations active in the years 1945-47, because, in addition to the large nationwide organizations, there were local initiatives: for example, the Circle of Former Prisoners of Treblinka, formed under the Central Committee of Polish Jews, had no more than a few dozen members ${ }^{37}$ Some associations merged and others fell apart: for example, the Union of Jewish Participants of the Armed Struggle against Fascism was founded in 1947 as a result of divisions in several other Jewish organizations. ${ }^{38}$

Meanwhile, from the point of view of state propaganda, the most important organization was the union that brought together the partisans who fought on German-occupied territory of Poland: the Union of Participants of the Armed Struggle for Independence and Democracy (Zwiazek Uczestników Walki Zbrojnej o Niepodległość i Demokrację, ZUWZoNiD), which operated under the auspices of the Polish Workers' Party. The organization was formed in 1945, but the significance of the partisan struggle against the Germans had been noted earlier, on 25 November 1944 in Lublin at the founding meeting of the ephemeral Union of Polish Partisans: here, Grzegorz Korczyński, who had fought in the Spanish Civil War and was a commander of the People's Army in Lublin region, put forward a series of arguments that would later characterize the dominant narratives of the Polish communists' memory of the war. These included the myth of partisan heroism and unity, the liberation myth relating to the pro-communist regular army and centred around the Battle of Lenino, ${ }^{39}$ the motif of blood sacrifice as a symbol

35 'Ustawa z 23 października 1975 o dalszym zwiększeniu świadczeń dla kombatantów i więźniów obozów koncentracyjnych', Dz.U. nr 34, poz. 186. For commentary of this statute, see: Uprawnienia kombatantów oraz członków ich rodzin w zakresie emerytur, rent i innych świadczeń socjalnych, Warszawa 1979.

36 'Ustawa z 6 maja 1945 o majątkach opuszczonych i porzuconych'. See also Dz.U. nr 30, poz. 179, art. 1; Dz.U. nr 17, poz. 97, art. 13.

37 See Zofia Wóycicka, 'Niezrealizowany projekt upamiętnienia terenu byłego obozu Zagłady w Treblince z 1947 roku. Próba analizy ikonograficznej’, in Michał Głowiński et al. (eds), Stosowność i forma. Jak opowiadać o Zagładzie? Kraków 2005, p. 328.

38 Związek Żydów Uczestników Walki Zbrojnej z Faszyzmem. According to data from the Main Directorate of ZBoWiD from 1949, this association had 5,000 registered members. See August Grabski, Żydowski ruch kombatancki w Polsce w latach 1944-1949, Warszawa 2002, p. 15. On divisions within the Jewish veterans' movement, see, ibid., pp. 19-91.

39 The Battle of Lenino (12-13 October 1943) took place north of the village of Lenino in the Mahiliou region of Belarus and was part of a larger Soviet operation against the German 
of Polish-Soviet friendship, and the conflicts between soldiers and partisans, which presaged later political conflicts among Polish communists in the 1960s (see Chapter 5). Korczyński stated, for example, that:

There is an unhealthy attitude emerging, whereby partisans are treated like bandits. When partisans encounter officers of the Polish Army, there are often instances of a dismissive attitude to the partisans. This hurts. We have shed no less blood than them. We had not one Lenino, but five a week. ${ }^{40}$

The format of ZUWZoNiD was discussed at a series of sessions of the central leadership of the PPR. ${ }^{41}$ As early as August 1945, representatives of the Secretariat of the PPR Central Committee were working out the details of a 'congress of participants of the underground struggle against the occupier', which was due to take place on the anniversary of the start of the war in September 1939. It was decided that the congress would be attended by members of the People's Army, the Peasants' Battalions and the Home Army. The official goals of the ZUWZoNiD, which would be founded as a result of the congress, were also established; they emphasized the welfare activities of the union. Moreover, the creation of organizing committees in the regions, in which a 'large presence of the partisan movement' should be visible, was mooted. The task of encouraging communist partisans to take part in the congress was entrusted by the Secretariat to Colonel Józef Sęk-Małecki, a member of the command staff of the AL, who soon after became the secretary of ZUWZoNiD.42 Two of the most prominent communists, President Bolesław Bierut and Marshal Michał Rola-Żymierski, were patrons of the congress, which took place in the Roma Theatre in central Warsaw, and the honorary committee included representatives of the main political factions who had fought in the underground movement during the war.

forces on the eastern bank of the Dnieper river. The battle was the first major operation of the Polish Armed Forces in the East (the Tadeusz Kościuszko Infantry Division), which was allied with the Red Army and formed mainly of former Gulag prisoners. It was commemorated by Polish communist propaganda as a major victory, which concealed the fact that the division suffered a high number of casualties and had to be withdrawn because of a lack of training and support, as well as its failure to cooperate with other Red Army units.

40 'Protokół z kongresu założycielskiego Polskiego Związku Partyzantów'. Information and quotation from: Lesiakowski, Moczar, p. 215.

41 'Protokół z posiedzenia Sekretariatu KC PPR, 29 lipca 1946' in Aleksander Kochański (ed.), Protokoły posiedzeń Sekretariatu KC PPR 1945-1946, Warszawa 2001, p. 273; 'Protokół nr 19 z posiedzenia Biura Politycznego, 4 września 1947’ in Aleksander Kochański (ed.), Protokoty z posiedzeń Biura Politycznego KC PPR 1947-1948, Warszawa 2002, p. 108.

42 'Protokół z posiedzenia Sekretariatu KC PPR, 11 sierpnia 1945' in Kochański (ed.), Protokoty posiedzeń Sekretariatu, p. 129. 


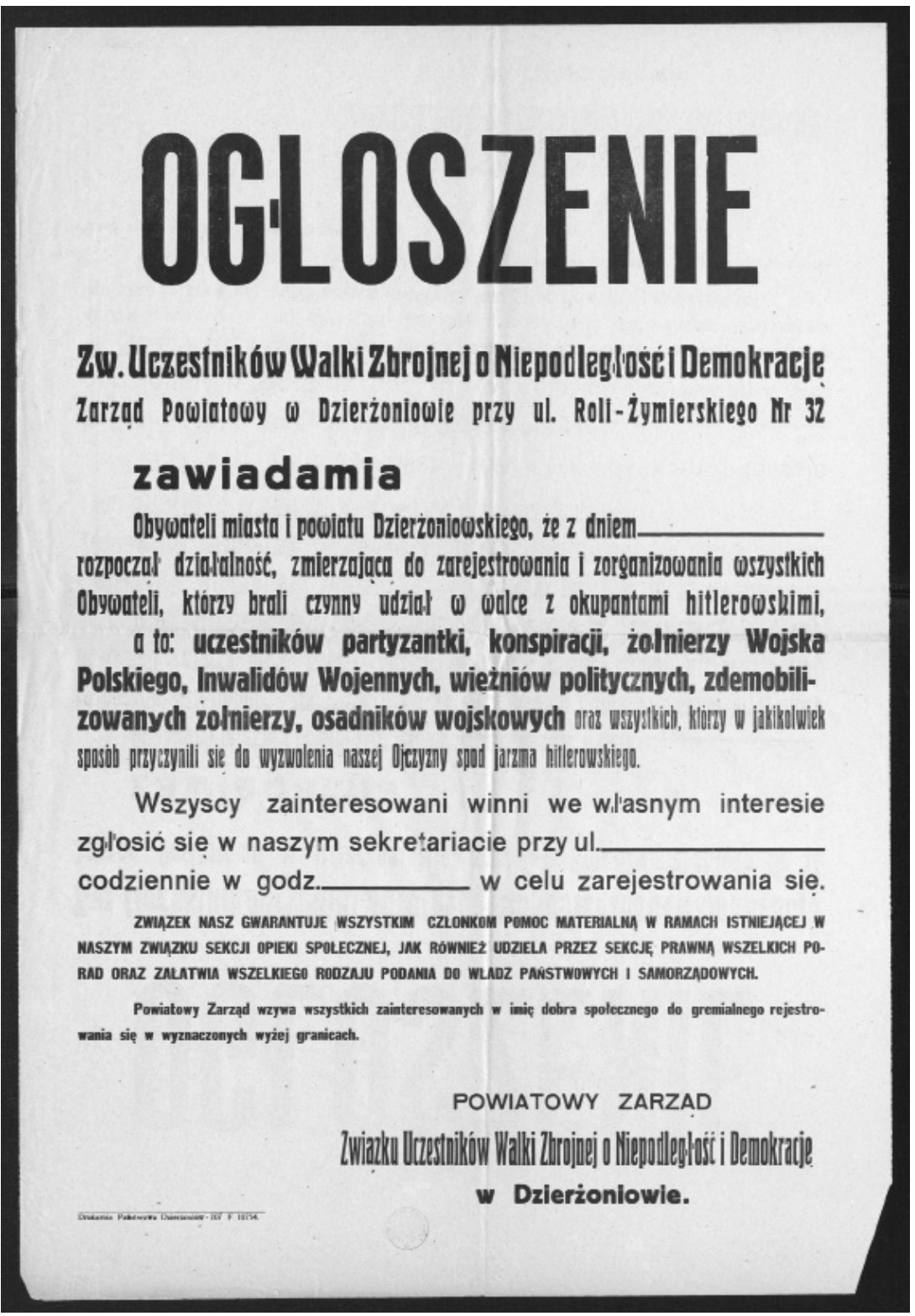

2.3 Appeal addressed to partisans, resistance members, and soldiers to join ZUWZoNiD; it offers benefits and legal assistance. National Library of Poland. 


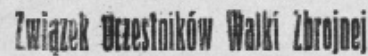

- Niepodleglośc i Demokrację

ZARZAD) ODDZIATU - - CHELMIE

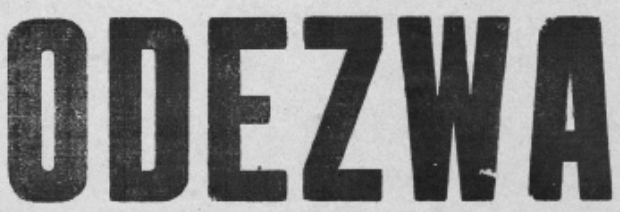

\section{Zdemobilizowani żomierze!}

Związek Uczestników Walki Zbrojnej o Niepodległość i Demokrację or Chelmie - zwraca się $\mathrm{z}$ apelem do wszystkich byłych żołnierzy i oficerów, którzy walczyli o Wolność i Niepodległość Ojezyzny z okupantem niemieckim o wzięcie udziału w Zjeździe, ktòry odbędzie się w dniu 13 lipca 1947 r. 0 godz. Il-ej (Gmach Glówıy Dyrekcji) w Chelmie.

Za poniesione walki, ofiary i trudy dla Polski w szeregach Zwycięskiej Armii Polskiej należy się Wam zasłużone miejsce wśród społeczeństwa.

W obronie Waszych interesów - Zdemobilizowani! - winniście wziąc udzial w ważnych obradach dotyezących Waszego przyszlego losu i Waszych wobyczy.
Sekrefarz:
Czlonek Zarzạdu:
Prezes:
$(-)$ J. KOWALEWSKI
(-) kpt. JAR SKI
Komendant R. K. U.
(-) J. JAR M U L
Starosta Powialowy

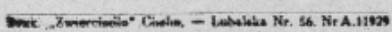

2.4 Appeal to demobilized soldiers to join ZUWZoNiD, 1947. National Library of Poland. 
The decisions taken by the Secretariat, the composition of the organizing committee, and above all, the choice of chairman of the new union - former chief of staff of the People's Army, Franciszek Jóźwiak - explicitly attempted to bring the partisan groups to order. The Home Army was the most numerous of the formations identified as 'the partisan forces' at the meeting, and its high command during the war had striven to gain primacy over other armed organizations by insisting on its continuity from the pre-war armed forces; according to the new order, however, it would be designated as just one of many groupings that had taken up 'the armed struggle against the occupier.'

After demobilization had been carried out, the government encouraged former soldiers of the regular armed forces to join the organization. This was one way of instilling the propagandistic message of 'unity' among those who had fought during the war. ${ }^{43}$ The next significant step was the merger of ZUWZoNiD with the large and strategically important union that operated in the formerly German regions, the Union of Military Settlers in the Recovered Territories (Zwiazek Osadników Wojskowych na Ziemiach Odzyskanych, ZOW), in September 1948. ZOW was an association that brought together demobilized soldiers who had settled in these areas. ${ }^{44}$ With the exception of the Union of War Invalids, it was the only combatants' association for regular soldiers. After the merger, the joint organization was renamed the Union of Fighters against Fascism and Hitlerite Aggression for Independence and Democracy (Zwiazek Bojowników z Faszyzmem $i$ Najazdem Hitlerowskim o Niepodległość i Demokrację), and it claimed to represent the interests of all groups that had fought against Nazi Germany.

However, the numerically largest and materially wealthiest organization was not a union of former fighters, but the association of former camp and prison internees: the Polish Union of Former Political Prisoners (Polski Zwiazek Bytych Więźniów Politycznych, PZbWP). ${ }^{45}$ It was formed in February 1946 as a result of putting together a number of grassroots formations. The chairman of its Main Directorate was Józef Cyrankiewicz, a socialist who two years later agreed to a

43 According to data from the Ministry of Public Safety (Ministerstwo Bezpieczeństwa Publicznego), ZUWZoNiD had around 32,000 members in 1947, among whom the bestrepresented groups were the People's Army $(8,400)$, followed by the Home Army $(7,300)$ and the Peasants' Battalions (7,100); the remainder was made up of former members of militias of the Polish Socialist Party $(1,200)$, soldiers $(3,300)$ and others $(6,200)$. 'Tabela statystyczna członków', 10 May 1947, AIPN, MSW II, 3854, p. 69.

44 Arkadiusz Ogrodowczyk, Nad Odra i Battykiem. Osadnictwo wojskowe na zachodnich $i$ pótnocnych ziemiach Polski po drugiej wojnie światowej, Warszawa 1979, p. 198.

45 According to official data from the spring of 1947, PZbWP had approximately 177,000 members and 260,000 people in its care (widows and orphans). The activity of the organization is discussed at greater length by Zofia Wóycicka: Arrested Mourning: Memory of the Nazi Camps in Poland 1944-1950, Frankfurt am Main, 2014, pp. 19-116. 
merger between a faction of the Polish Socialist Party (Polska Partia Socjalistyczna, PPS) and the communist Polish Workers' Party, forming in 1948 the Polish United Workers' Party (Polska Zjednoczona Partia Robotnicza, PZPR), which would rule Poland for the next four decades. Cyrankiewicz himself served as prime minister of Poland until 1970. He had spent three years in Auschwitz as a Polish political prisoner, a fact that was often underlined by the state propaganda. According to its own declarations, PZbWP brought together individuals who had been persecuted by the Germans in prisons and camps as punishment for their conspiratorial activity within the (broadly defined) civil resistance movement. However, the regulations of its verification commission provided for the possible eligibility of people who had been interned on the racist grounds because of their Jewish or Slavic ethnicity; in other words, PZbWP de facto aimed to unite the majority of victims of Nazi occupation policy, with the exception of criminal offenders. ${ }^{46}$

To complete this overview of major associations active after the war, mention must be made of the unions of Veterans of the Silesian Uprisings (Zwiazek Weteranów Powstań Ślaskich, ZWPŚ) and the Wielkopolska Insurgents of 1918-19 (Zwiąek Powstańców Wielkopolskich, ZPW). These organizations were exceptional in that they were not in any way connected to the memory of the Second World War, nor did they have roots in communist ideology: they united the participants of the largely successful borderlands conflicts with Germans in the aftermath of the Great War. After the Second World War, their activity was not only permitted, but actively supported for ideological reasons: both associations promoted the idea of the 'ageold Polishness' of the western regions. In other words, they were utilized for the legitimization of the system, through their appeal to patriotic and anti-German sentiment. Although ZWPŚ was not formally a direct heir of the pre-war Union of Silesian Insurgents, it counted some of the latter's activists among its members. ${ }^{47}$

Finally, there were also a number of communist organizations that brought together veterans from pre-war times; these were relatively small. The Union of Participants in the Fight for the Freedom of Spain in 1936-39, informally known as the Union of Dąbrowski Soldiers (Związek Dąbrowszczaków) because the Polish battalion (later, brigade) that fought among the international brigades on the republican side bore the name of the Polish left-wing military leader Jarosław Dąbrowski (1836-1871), was founded in November 1945 and in 1949 had 1200 members, of whom 402 lived abroad, chiefly in France. ${ }^{48}$ Its significant

46 Anon.,'Kto może i powinien należeć do Związku', Wolni Ludzie 5 (1947), p. 7.

47 Andrzej Stelmach, Historia ZBoWiD, unpublished manuscript in the possession of the Union of Veterans of the Republic of Poland and Former Political Prisoners (Zwiazek Kombatantów Rzeczypospolitej Polskiej i bylych Więźniów Politycznych, AZGZKRPiBWP), 1989.

48 'Stan liczbowy b. Związku Dąbrowszczaków z 20 września 1949', AAN, Grupa Akt ZBoWiD, 2, p. 10. 
characteristics included a strong solidarity among its members and the participation of several of its leaders in the state power apparatus. The Union of Veterans of the Revolutionary Struggles of 1905-18, created in Łódź in August 1945, brought together individuals who had been repressed before the Second World War for their involvement in the communist movement.

All of the unions kept registers of their members; the largest unions, ZOW, PZbWP and ZUWZoNiD, claimed to have nearly 100,000 people registered in each association. Nonetheless, in a country ravaged by war, it was impossible to maintain accurate records. The available quantitative data do not allow us to establish how involved the members actually were; many may have been inactive enough so as to be later deprived of their membership. Moreover, organizations that operated on some state subsidies would have been motivated to artificially inflate their numbers. Finally, information concerning wartime activities may also be unreliable: members of the Home Army and of other non-communist formations sometimes concealed their past. One veteran I interviewed was a member of a nationalist organization during the war, but also served a short time in 1945 as a soldier of the Polish Armed Forces in the East; it was the latter that provided the pretext for his membership in ZUWZoNiD. He preferred to keep his involvement in the wartime underground secret, because, in his words, 'what good would have come from my explaining?'49

\section{Memory Groups: A View from Below}

\section{Commemoration: 'I can still smell that putrid stench'50}

When the state was consolidating its powers, Poles lived in a state of 'live memory': searching for loved ones, digging up corpses and arranging their funerals. Let us have a look at two examples: the Polish capital and the sites of former extermination camps. In Warsaw in the immediate aftermath of the war, human remains, piles of rubble, burned houses and the stench of death defined everyday reality; the living led their lives next to stinking and decaying corpses, families looked for the bodies of those dear to them, children played with bones, temporary graves were robbed, and arguments flared up as to who could be buried where. ${ }^{51}$ The experience of corpse became the most poignant epilogue to the war.

49 Interview with P.B., July 2004.

50 Oral testimony by Mieczysław Chodźko, AŻIH, zespół Pamiętniki, 302/321, p. 103, 104. Cited in Martyna Rusiniak, 'Treblinka - Eldorado Podlasia', Kwartalnik Historii Żydów 2, 218 (2006), p. 206.

51 Jacek Z. Sawicki, Bitwa o prawdę. Historia zmagań o pamięć Powstania Warszawskiego 1944-1989, Warszawa, pp. 44-46. 


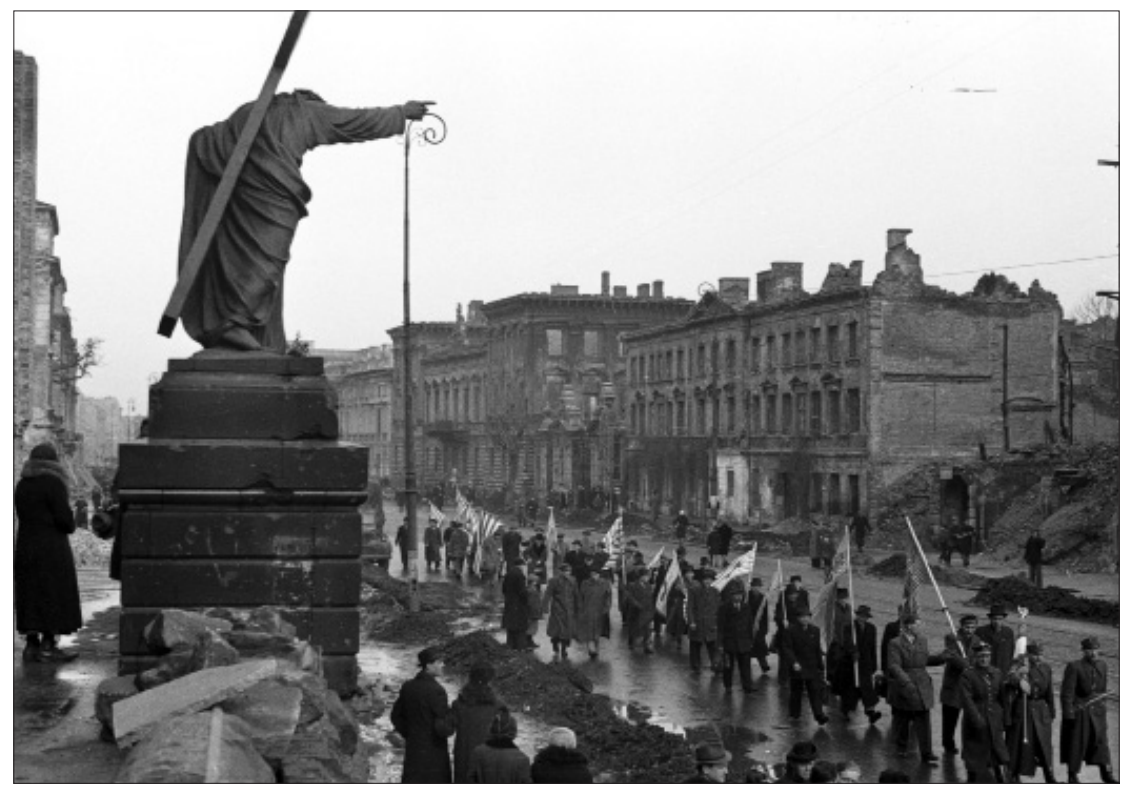

2.5 March organized by Polish Union of Former Political Prisoners, Krakowskie

Przedmieście Street, Warsaw, March 1947. Photo by Jerzy Baranowski, National Digital Archives/Polish Press Agency.

For people returning to Warsaw, the sight of lifeless bodies became something familiar - as quotidian as the sight of ruins or the necessity of finding the means for survival in a destroyed city. Hundreds of descriptions of Warsaw are available in the documentary collections of the Polish Red Cross for 1945, e.g.:52 'a grave without a cross, a leg protruding, unidentified. A grave by the stadium covered only by a net, three unburied persons in a pile of tomatoes' (Myśliwiecka Street, March 1945); 'site of execution of 28 people. In the vestibule of a stairwell leading from a courtyard, charred bones and the remains of a person, supposedly a man called Stefan, who lived on the fourth floor of this building, tall, broad-shouldered, a fruit-seller ... In a shop on the corner, covered in rubble, unidentified corpses. In the shop in the courtyard, two corpses, one of them had a prosthesis (stolen)' (17 Grójecka Street); 'the university gardens, left of the gate, the remains of a woman in full decomposition' (7 Browarna Street); 'in the watchman's apartment, the charred remains of a newborn infant lie on the window sill' (5 Skolimowska

52 Robert Bielecki, Żotnierze Powstania Warszawskiego. Dokumenty z Archiwum Polskiego Czerwonego Krzyża, vol. 3, Warszawa 1997, pp. 17-135. 
Street). These sketches, so terrible in their brevity, relate to practically the whole of left-bank Warsaw.

The collective of survivors faced a dilemma. Should they remove the corpses as quickly as possible or wait to give them proper burials? The city was under the threat of an epidemic. The then-head of the city administration's health and social department recalled: 'every day at dawn, I held in my shivering hand the epidemic report ... and every evening, in the company of my colleagues, we looked back at the bygone day with a sense of relief that another day had passed, that we had managed. ${ }^{53}$ Some in the administration advocated immediate incineration of all the corpses. However, this project was considered too barbaric. Notices such as this one, observed by staff of the Polish Red Cross at the cemetery on Miodowa Street, were not rare: 'Please do not dig up these remains for the time being. Parents are on their way to Poland, they will bury them. ${ }^{54}$

However, there was a shortage of space in the cemeteries. The city authorities accepted a proposal from the Polish Red Cross to place human remains in temporary graves, and to transfer them to cemeteries once plots had been prepared. Leftbank Warsaw was divided into sectors, in which two-person teams from the Polish Red Cross, mostly comprised of women, tried to reach burned-down buildings and gardens in order to collect information about corpses before their transfer to mass graves.

Corpses were a source of conflict: they had political significance. In the first quarter of 1945, former insurgents of the 1944 Warsaw Uprising received a secret order to contribute to the work of the Polish Red Cross in locating the bodies of Home Army participants of the Warsaw Uprising, as well as to advise semi-formal families' committees (also called cemetery committees) on where to bury their loved ones. Officials of the AK wanted as many bodies as possible to be identified and transferred to Powązki military cemetery, Poland's main military burial ground, where they would be symbolically united with the graves of soldiers who had died in the Soviet-Polish war of 1920 and in the 1939 defensive war, as well as with young partisans of the so-called Storm Groups of the Grey Ranks of the Home Army who had been clandestinely buried there during the Nazi occupation of Warsaw.

Meanwhile, the city authorities insisted on burying unidentified bodies in Wola cemetery, which was less central and prestigious, and in a number of smaller burial grounds on the outskirts of Warsaw. The identity of those who were buried in this way was concealed under the anonymous formulation 'the heroic people of Warsaw'. It was in August 1946 that the largest burial operation under this

53 Jan Górski, Drugie narodziny miasta. Warszawa 1945, Warszawa 1976.

54 Bielecki, p. 18. 
heading was carried out: open-top trucks transported 117 giant coffins containing over eight tonnes of human ash to Wola cemetery. ${ }^{55}$

As time passed, the party and the government grew increasingly hostile to the burial of AK soldiers in Powązki military cemetery. The army was in charge of overseeing the cemetery, and it commissioned ZUWZoNiD to take decisions on military burials. Partly following orders from above and partly through its own organizational inertia, the union refused burial to participants of the Warsaw Uprising. In the spring of 1947, former Home Army colonel Jan Mazurkiewicz wrote to Józef Cyrankiewicz to request intervention: there were many coffins in the cemetery chapel that had remained unburied since the autumn. The situation in Wola was even worse: exhumed corpses had not been put into coffins at all, and were lying in a shed. During a particularly wet spring, 'water and rain flooded the remains of the bodies, mixing them up, and families [were] deprived of the remains they held dear. ${ }^{56}$ Finally, numerous Home Army soldiers were buried at the military cemetery, but the names of many remain unknown and their graves are marked only by the identification numbers provided by the Polish Red Cross.

The situation in Warsaw was bleak, but there did exist norms of military commemoration that had become cemented as usual practice in the pre-war period, and these were what the Home Army circles aspired to and quarrelled about with the new authorities. The question of how to treat the ashes was much more complicated with regard to the victims of genocide throughout the country. There were no inherited pre-war models for the commemoration of mass atrocities. ${ }^{57}$ The largest cemeteries in Poland were the sites of the Nazi concentration and extermination camps, and the debates started with questions about the identity of victims buried there. Who were the murdered: people who had been targeted randomly or the participants of the resistance movement who had died 'for a cause'? If the latter, for what cause did they give up their lives: for the 'freedom of the nation' or for 'the progress of humanity'? Was the meaning of their suffering to be found in their Polishness, Jewishness, belief in God, or belief in communism? In the post-war years, what was sought was the heroization of mass death. ${ }^{58}$

55 Tomasz Markiewicz, 'Der Kampf um die Erinnerung. Denkmäler der Heimatarmee in Warschau seit 1945' in Bernard Chiari and Jerzy Kochanowski (eds), Geschichte und Mythos der Armia Krajowa seit dem Zweiten Weltkrieg, München 2003, pp. 753-755.

56 A letter from Jan Mazurkiewicz to prime minister Józef Cyrankiewicz, Warsaw, 19 April 1947. I am grateful to Stanisław Mazurkiewicz for sharing with me this and other documents.

57 Zbigniew Mazur, 'Upamiętnianie w latach 1945-1948 ofiar niemieckiej okupacji', Przegląd Zachodni 4, 60 (2004), pp. 133-157.

58 Maria Janion, “Nie-boska komedia” - skażone arcydzieło', Gazeta Wyborcza, 29 March 2008. 
Historian Zofia Wóycicka has analysed personal reminiscences, newspapers and magazines, and memoranda issued by a number of organizations, concluding that public debate was dominated by a narrative of Polish martyrdom. Wóycicka's study refutes, however, the common assertion that the specific character of the Holocaust was ignored in the early post-war years; it shows that commentators did see the difference between the wartime fate of Jewish and non-Jewish victims. Nonetheless, non-Jewish authors focused on the 'Polish' experience, generally remaining indifferent to genocide in the extermination camps. Jewish memory developed in isolation; narratives of Jewish suffering were confined to publications by Polish Jews and did not reach a wider readership. Moreover, this discourse also remained under the influence of the idea of heroic death, and thus it sometimes ascribed a greater significance to the resistance in the Warsaw Ghetto than to the mass extermination of the death camps. ${ }^{59}$

Pieter Lagrou, who noticed similar tendencies in post-war Western Europe, draws an analogy with the early Christian understanding of martyrdom: martyrs are not ordinary or random victims of persecution, but are specifically targeted because of their religion, and their suffering acts as the strongest evidence of their faith; suffering is a realization and embodiment of providence. According to Lagrou, modern nationalism has secularized the Christian vision of martyrdom and in consequence enabled the interpretation of mass death in the camps as a heroic offering to the national cause.$^{60}$ In Poland, such a vision of the camps was especially powerful, as a result of the traditions of Polish Romanticism and Catholic culture, where religious and patriotic sentiment are closely entangled. The idea of Poland as a 'Christ of Nations ${ }^{\text {'61 }}$ had grown out of the nineteenth-century history of Poland's existence under partition, was present in national education in the inter-war period, and had therefore survived into post-war conceptions of Polish identity. Initially, even party-sponsored victims' associations were not immune to the influence of Catholic messianism.

The dominant interpretations of the camps were maintained through selective commemoration of physical sites. The Nazi concentration camps

59 Wóycicka, Arrested Mourning, pp. 71-116.

60 Lagrou, p. 211, 212.

61 The concept has its roots in days of Ottoman expansion and the wars waged by Polish kings against the Muslim Turks. In the nineteenth century it was revived by authors such as Adam Mickiewicz (1798-1855), a romantic poet who spent much of his creative life in exile. In such messianic and revolutionary visions, the partitions of Poland between Austria, Prussia and Russia at the end of the eighteenth century came to be seen as a Polish sacrifice for other nations. The suffering of the Poles was to bring salvation to Europe, just as the death of Christ brought redemption to mankind. See, for instance: Brian Porter, When Nationalism Began to Hate: Imagining Modern Politics in Nineteenth-century Poland, Oxford 2000. 
at Stutthof and Gross-Rosen and extermination camps at Treblinka, Bełżec, Sobibór and Chełmno were for at least a decade neglected by the state, and plundered by looters. One of many 'treasure hunters' at Treblinka justifies his own activity with the phrase 'everyone did it'. A man who was accused in court of stealing a diamond stated in his defence that: 'I did not know that looking for gold and other valuables in the territory of the former camp at Treblinka was forbidden; Soviet soldiers were in there with us, also searching. ${ }^{92}$ On the other hand, Majdanek and Auschwitz-Birkenau were given the status of national monuments. The editors of PZbWP's magazine Wolni Ludzie ('Free People') argued in a series of articles that the creation of a museum at Auschwitz should be a particular priority. In response to questions and protests from individuals who had been interned at other camps, they justified their choice by appealing to the scale of the crimes. Auschwitz was intended to become a metonymic symbol for all of the atrocities committed by the Nazis. ${ }^{63}$

The memorialization of Auschwitz was nonetheless given an air of authenticity by the fact that the museum's first roll of staff - from the director down to the custodian, artists and security personnel - was composed of former inmates. ${ }^{64}$ The first exhibition, created in the summer of 1945, was housed in two barracks on the territory of Auschwitz-I. An illuminated cross dominated the exhibition, which included objects that had been left behind by the victims, encircled by barbed wire; this gave the narrative of suffering a Christian martyrological meaning. The museum's opening ceremony took place in 1947, on the seventh anniversary of the arrival of the first transport of Polish prisoners at the camp. The exhibition was expanded into several more buildings - and prepared in consultation with the central organs of state power and $\mathrm{PZbWP}^{65}$ - but only one block was dedicated to the fate of the Jews. Birkenau, the site of immediate mass death where the majority of the camp's victims were killed, was neglected; the emphasis was consistently on the site of Auschwitz-I.

All in all, in the whole of Poland, despite communists consolidating their power, the rituals for commemorating the dead were predominantly Catholic: the funerals, memorial events, and unveilings of monuments and plaques were almost always accompanied by a religious service. At the same time, a martyrological interpretation of the Second World War was emerging: published obituaries sang the praises of war's martyrs; union newspapers issued lists of the dead and missing;

62 Rusiniak, p. 207. More in Jan T. Gross and Irena Grudzińska-Gross, Golden Harvest: Events at the Periphery of the Holocaust, New York 2012.

63 'Dlaczego Oświęcim?', Wolni Ludzie 3 (1947), p. 2.

64 Jonathan Huener, Auschwitz, Poland, and the Politics of Commemoration, 1945-1979, Athens 2003, p. 62; Wóycicka, Die Kanalisierung, pp. 183f.

65 Huener, p. 71. 
veterans and former political prisoners' associations ran competitions for war stories and personal memoirs. In this way, a narrative of heroic wartime suffering was constructed that involved both specific groups and society as a whole.

\section{Assistive activities and group interests}

Sub-colonel Edward Brandstetter reported to his superiors in July 1946:

The Main Political-Educational Directorate of the Polish Armed Forces is visited every day by entire phalanxes of invalids, demobilized soldiers, and military settlers bearing complaints about the absence of any kind of material support whatsoever from the civil authorities. Thus, the issue of maintaining the livelihoods of demobilized and disabled soldiers will be a burning problem for a long time to come, and requires a radical solution. ${ }^{66}$

The problem of physical disability and illness did not only affect former soldiers. Archival materials from all of the veterans' and victims' associations that were in existence at this time indicate that they were trying to secure maintenance benefits for the disabled and sick. Alina Tetmajer, who was responsible for social welfare at the Union of Former Political Prisoners, divided the organization's members into three groups: 'unable to work', 'requiring long-term or permanent assistance' and those would need help in 'getting back on their feet'. ${ }^{67}$ Other defenceless groups in the harsh realities of post-war life included people who had lost the only breadwinner in the family: elderly parents, widows and orphans, abandoned spouses, and those who were malnourished and susceptible to illness, especially tuberculosis. All of the larger unions had plans to set up nurseries for the orphaned children of 'deceased comrades', as well as schools, scholarships, children's colonies and feeding stations. Several orphanages, preventoria and medical centres for children were operated by the associations, ${ }^{68}$ clothes and food were distributed by the United Nations Relief and Rehabilitation Administration (UNRRA).

66 'Sprawozdanie z pracy Głównego Zarządu Politycznego Wojska Polskiego za lipiec 1946 skierowane do szefa zastępcy naczelnego dowódcy WP ppłk Mankiewicza przez p.o. szefa oddziału II Głównego Zarządu Politycznego Wojska Polskiego ppłk Brandstettera', CAW IV 502/1, p. 13.

67 Alina Tetmajer, 'Nasza opieka społeczna', Wolni Ludzie, 2 (1947), p. 7.

68 Jerzy Kirchmayer, 'Sprawa opieki', Polska Niepodległa 2 (1946), p. 3; 'Sprawozdanie z działalności w zakresie opieki nad dzieckiem i młodzieżą, 1946-1948', AZGZKRPiBWP 3, 11, p. 64-71; Henryk Rechowicz, Powstańcy ślascy w Polsce Ludowej 1945-1949, Katowice 1970, pp. 136-144; Ogrodowczyk, p. 213, 214; 'Sprawozdanie z działalności Komisji Likwidacyjnej’, AAN, Grupa Akt ZBoWiD, 2, pp. 1-19. 
Union activists strove to obtain favourable legal reforms and lobbied for statutory solutions. The larger associations earned a portion of their income through concessions they had gained for the sale of spirits. At the same time, they established numerous commercial enterprises, mostly co-operatives, whose main purpose (other than any expected profit) was to create places of work for veterans and former prisoners, in particular those who would face difficulties finding employment because of physical or mental incapacitation. As one activist emphasized, 'We can create workshops with no profitability whatsoever, indeed they may even be loss-making; but they will be fulfilling a useful purpose by employing our members and associates. ${ }^{69}$ Because of their economic activity and patronage, some of the veterans' and victims' unions became large institutions. For example, in Olsztyn, PZbWP ran a club called 'Casino', six grocery and textiles shops, a tailor's shop and a coal- and coke-trading enterprise. ${ }^{70}$ Countrywide, PZbWP owned 26 manufacturing and handiwork cooperatives, seven agricultural holdings, the Central Retail Trading group (Centrala Handlu Detalicznego - comprising around 300 clothing shops throughout Poland), eighteen relaxation resorts and sanatoria, three orphanages and one foster care home. ${ }^{71}$ By December 1947, ZOW had created approximately 300 co-operatives of various types in the west and north of the country, including bakeries, butcher's shops, dairy shops, hotels, relaxation resorts, and eateries. ${ }^{72}$

It is difficult to determine the extent to which these patronage and commercial activities fulfilled the needs of the associations' rank-and-file. Numerous diverse documents contain complaints about the abuse of this system and incompetence in managing communal property. These voices of displeasure are however hard to separate from the general circumstances of the time: the material poverty of a society in which clothes delivered by UNRRA were a source of envy, the dominance of the new ideology, as well as sheer nepotism. The staff of the shops operating under the overall framework of the Central Retail Trading group, which distributed clothes at set non-market prices, were accused of theft and profiteering. ${ }^{73}$ An informer of the Public Security reported that children from orphanages managed by ZUWZoNiD were clothed in rags, and that moths had eaten entire bundles of

69 'Sprawozdanie Głównej Komisji Rewizyjnej PZbWP', 18 March 1947, AZGZKRPiBWP 8,2 , n.pag.

70 Jan Błesiński et al., 'Ruch kombatancki na Warmii i Mazurach w latach 1945-1985' in Ruch kombatancki na Warmii i Mazurach w latach 1945-1985, Olsztyn 1985, p. 14, 15.

71 Czesław Łęski, ‘Jak pracuje nasz Związek?', Wolni Ludzie 2 (1947), p. 2.

72 Ogrodowczyk, p. 213, 214.

73 'Do Rady Naczelnej PZbWP'; 'Protokoły z posiedzeń Głównej Komisji Rewizyjnej za lata 1947-1948'; 'Sprawozdanie Głównej Komisji Rewizyjnej PZbWP', 18 March 1947. 'Protokół z zebrania przewodniczących okręgowych komisji rewizyjnych PZbWP', AZGZKRPiBWP A, 8/1, 8/2, n.pag. Also see subsequent issues of Wolni Ludzie for the year 1947, in which this theme is given further treatment. 
clothes in the storehouses. ${ }^{74}$ The wife of Jerzy Kirchmayer, the deputy chairman of ZUWZoNiD, recalled some years later that her husband had one day returned in a state of agitation from an inspection of one of the organization's nurseries. The centre's director had been feeding his own large family with supplies intended for the nursery children, and the children of party functionaries were enjoying special privileges, including better food. ${ }^{75}$

In addition to the basic functions that were largely the same among various associations, such as commemorating the dead and assisting the living, the unions also had specific interests that were characteristic of the groups they represented. To an extent, the various associations were based on the fundamentally contrasting wartime experiences of their members (regular soldiers, partisans, and camp prisoners). However, from the very beginning, authentic and spontaneous attempts at self-organization were hindered by orders issued by the party. Most notably, the state did not allow the creation of ex-combatants' groups that brought veterans together according to their political views (i.e. those who were not in agreement with the party); in contrast, in Western Europe, as shown in the previous chapter, political motives often provided the basis for the creation of diverse associations of members of the resistance movement. ${ }^{76}$

The clearest example of state interference was the treatment of former members of the Home Army who decided to come out of the clandestine underground and enter the public sphere. The failure of plans drawn up by aforementioned Jan Mazurkiewicz is an excellent illustration. Mazurkiewicz began his career as a private who fought for Poland's independence in the Great War, and was a professional serviceman (and for some time an intelligence officer) in the inter-war period; during the Second World War he led the Sabotage Division (Kedyw) of the Home Army and was one of the most celebrated leaders of the Warsaw Uprising, about whose personal bravery legends were told. However, he did not enter the anti-communist underground. After a short arrest in August 1945, Mazurkiewicz decided to withdraw his subordinates from the conspiracy movement, and to work in the official structures of the Home Army liquidation commission. Working in the liquidation commission and carrying out exhumations gave Mazurkiewicz an idea of the scale of destruction that had affected Poland by the end of the war. He concluded that fighting had lost its meaning. ${ }^{77} \mathrm{He}$ let himself be led by a feeling of duty to the living and the dead, to the soldiers who were under his command

74 'Charakterystyka ZUWZoNiD', 1 July 1947, AIPN 00231/176, 6, p. 37.

75 Wanda Kirchmayer, Z Jerzym na dobre i złe, Warszawa 1992, p. 111.

76 Lagrou, pp. 42-47.

77 Stanisław Mazurkiewicz, Jan Mazurkiewicz. 'Radosław', 'Sęp', 'Zagłoba', Warszawa 1994, p. 372. Sawicki, Bitwa o prawdę, p. 101. Interview with Stanisław Mazurkiewicz, July 2004. 
- or at least that is what he claimed several years later during an interrogation in Stalinist prison. ${ }^{78} \mathrm{He}$ contributed to the erection of the 'Gloria Victis' monument in Powązki Cemetery in Warsaw (see figure 2.6), and the establishment of nurseries for the orphaned children of participants of the Warsaw Uprising. Mazurkiewicz also petitioned various state institutions with diverse requests: to free imprisoned AK soldiers, to verify officer ranks, to provide for widows and orphans, to award scholarships to students, and to organize work for the unemployed. ${ }^{79}$

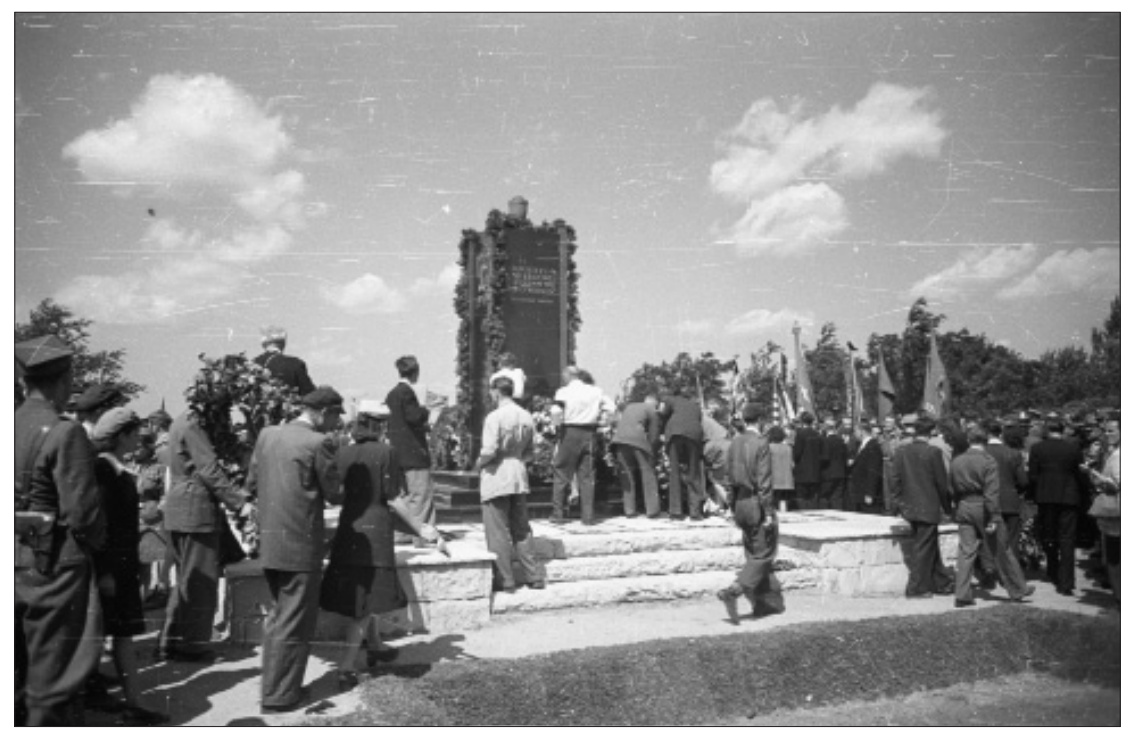

2.6 Unveiling of the 'Gloria Victis' Memorial dedicated to the Home Army, the second anniversary of the Warsaw Uprising, Powazki Military Cemetery, Warsaw, 1 August 1946. Photo by Jerzy Baranowski, Polish Press Agency.

He acted to protect the group interests of Home Army circles. Initially, he wanted to establish a union of former soldiers of the AK. He even believed that a political party could result. ${ }^{80}$ His efforts were quickly quashed by the authorities, who tolerated the presence of the Home Army exclusively within the framework of ZUWZoNiD, founded in 1945. Mazurkiewicz therefore modified his strategy: he encouraged Home Army members to join the official veterans' union, the armed forces and other

78 'Protokół przesłuchania podejrzanego', 1 December 1950, AIPN 765/335, p. 213.

79 Ibid., p. 212.

80 'Protokoły przesłuchania podejrzanego', 18, 27 November, 5 December 1950, AIPN $765 / 335$, p. 206, 209, 210, 218. 
institutions of the new Polish state ${ }^{81}$ Mazurkiewicz himself stated: 'I promoted the usefulness of us joining the union as a group, as this would give us the opportunity to obtain a corresponding number of seats in regional directorates [of ZUWZoNiD], and therefore a way of protecting our interests within the framework of a union. ${ }^{82}$ However, his activity did not go unnoticed in the corridors of power. The Political Bureau of the PPR Central Committee decided to act, as the following statement shows: 'In view of [Mazurkiewicz's] move to join the Union of Participants of the Armed Struggle, it has been decided that he must not be allowed to take any position of power within this combatants' union, and he should be informed of this in plain terms. ${ }^{83}$ The fiasco of these attempts to function legally within the structures of the new state was made public several years later: some of the individuals involved were arrested, and in 1949 Mazurkiewicz himself was imprisoned once more.

It was not only the Home Army veterans that had special interests forming the basis for their group solidarity. The genocidal war in which Jewish partisans and soldiers had participated had resulted in the murder of most of their relatives. According to historian August Grabski, it was for this reason that for many Jewish veterans, former comrades-in-arms were the only people with whom they could maintain close ties, which led to the strengthening of group solidarity. ${ }^{84}$ Grabski argues that the Jewish veterans support for the new political order was the result of both their wartime suffering and the prevalence of anti-Semitism in postwar Poland. A resolution approved at the first meeting of the Union of Jewish Partisans declared full support for the Polish Committee of National Liberation and the State National Council and also stated that 'the Polish reactionary forces operating under the signs of the NSZ and AK throughout the occupation period murdered Jews in hiding with no scruples whatsoever. ${ }^{95}$

The Union of Veterans of the Silesian Uprisings was another organization with a noteworthy identity. From a propaganda perspective, it was supposed to exemplify the striving of Poles to regain the 'historically Polish' territories that had been 'occupied' by Germans for centuries. Speaking at a congress of Silesian insurgents in 1946 in Bytom, Colonel Jerzy Ziętek argued for the significance of the pivotal and historically inevitable victory of socialism:

For us Insurgents, the main result of the Second World War was the end of the struggle to return all of the Silesian lands, ancient Polish territories, to the bosom of its common

81 Interview with C.Z., November 2004.

82 'Protokół przesłuchania podejrzanego', 27 November 1950, AIPN 765/335, p. 215.

83 'Protokół nr 18 z posiedzenia Biura Politycznego', 10 July 1947, in Kochański (ed.), Protokoty z posiedzeń Biura Politycznego, p. 108.

84 Grabski, p. 14.

85 'Rezolucja uchwalona na zebraniu partyzantów żydowskich w Lublinie', Biuletyn $\dot{Z} A P, 4$ (1945), p. 2, 3, cited in Grabski, p. 44. 
Fatherland. The fight against Germanization has ended for us. Now nothing endangers our beautiful, old Polish customs, which we have preserved despite many centuries of oppression. Today they have become a valuable contribution to the great cultural treasure trove of the Polish people. ${ }^{86}$

However, behind this rhetoric was a hidden agenda - most importantly, the 'forgetting' of the Volksliste, which local people had signed either willingly or under duress during the war. Under the new Polish regime, the presence of one's name on the list could be a cause for punishment. Former soldiers of the Wehrmacht ${ }^{87}$ who were conscripted by force were, however, eligible to apply for membership in this union, as were former concentration camp inmates. Members of ZWPS worked on rehabilitation and verification commissions, sometimes even intervening to prevent forced deportation of Silesian Poles to the USSR or Western Germany, ${ }^{88}$ but also assisting in the 'liquidation of ambiguities in matters of nationality and the removal of the traces of Germanness.' 89 ZWPŚ therefore became both an instrument in the Polonization of Silesia and also an institution that protected local people from arbitrary decisions taken during the verification of nationality and the transfer of the German population.

Finally, soldiers who had fought in the Polish Armed Forces in the East formed a large group of people adapting to life in the newly acquired territories. The formerly German lands were populated by new residents: those who had previously lived in the eastern territories of pre-war Poland (ceded to the Belarusian, Lithuanian and Ukrainian Soviet Socialist Republics), settlers from central Poland who moved in search of better opportunities, surviving Jews who were planning to emigrate to Palestine, Polish returnees from France, and Ukrainians and Lemkos transferred by force. ${ }^{90}$ Recruits of the Polish Armed Forces in the East (created in large part from former prisoners of Soviet labour camps, who had been residents of the Polish lands annexed by the USSR in September 1939) were promised new houses in the aftermath of victory in the territories that Poland would gain from Germany. ${ }^{91}$ As the army marched west

86 Colonel Jerzy Ziętek, 'Na front pracy! Z okazji Zjazdu Powstańczego w Bytomiu dnia 6.X.1946', Ogniwa, 2, 6 October 1946.

87 On Poles in Wehrmacht see Ryszard Kaczmarek, Polacy w Wehrmachcie, Kraków 2010.

88 Henryk Rechowicz, Związek Weteranów Powstań Ślaskich. 1945-1949, Katowice 1966, p. 43.

89 Ibid., p. 41. See also Rechowicz, Powstańcy śląscy, pp. 97-106.

90 In 1947 Ukrainians, Boykos and Lemkos living in south-eastern Poland were forcibly resettled to formerly German territories. The action targeted at civilians was carried out with the aim of removing support to the Ukrainian Insurgent Army's (UPA) operations. Parallel deportations were undertaken by NKVD in Soviet Ukraine.

91 Krystyna Kersten, 'Osadnictwo wojskowe w 1945 roku. Próba charakterystyki', Przegląd Historyczny 4, 55 (1964), p. 641, 642. 
through the territory of Poland, the promise of land rewards was extended to soldiers of the underground resistance forces. ${ }^{92}$

The terms of resettlement in the western regions were made more precise in May and June 1945. Military personnel and demobilized soldiers would create a 'border-zone cordon' to ensure security, contribute to the deportation of Germans and help new military settlers in the settlement process. The initiative's promotional materials emphasized that 'settlements radiating [our] strength and national spirit' would be established along the border at the Oder-Neisse line. ${ }^{93}$ Initially, plans were put in place for men to settle exclusively in that narrow strip, but it soon transpired that this area would not suffice, especially once part of the promised land was taken by civilians. As a result, all of the newly acquired territory in the north and west of the country was made available to military settlers. According to available estimates, in the first three years after the end of the war, soldier settlers and their families constituted around 12 percent of all new arrivals in the formerly German territories (i.e. around 500,000 people). ${ }^{94}$

In communist propaganda, the military settler embodied strategic protection of the Oder-Neisse border, ownership and successful management of the land, and the struggle for national and class emancipation..${ }^{95}$ One general proclaimed in April 1946:

Today on the western border of Poland, a rampart of Polishness has been built and fortified - the military settler movement. The bodies of the deceased testify to our right to a border at the Oder, the Neisse, and the Baltic Sea better than any border posts do. And the work of the Polish peasant and worker also testify to this right. Already for the second time in a single year, the military settler is ploughing and sowing in the Recovered Territories. Thousands of chimneys are being filled with smoke in previously abandoned and destroyed factories, and it is the Polish worker, engineer, and civil servant who is working there. ${ }^{96}$

92 Patrycy Dziurzyński, 'Udział WP w zasiedlaniu Ziem Odzyskanych', Przegląd Zachodni 1-2, 23 (1967), p. 87, 88; Kazimierz Mamak, Osadnictwo wojskowe na Ziemi Lubuskiej, Poznań 1979, pp. 20-32.

93 The order to settle there was given by the Commander-in-chief of the Polish Armed Forces on 3 June 1945. Kersten, Osadnictwo wojskowe w 1945 roku, p. 645.

94 Ogrodowczyk, p. 170.

95 Jerzy Holzer, 'Uraz, nacjonalizm, manipulacja. Kwestia niemiecka w komunistycznej Polsce', Rocznik Polsko-Niemiecki 1, 1 (1992); Jadwiga Kiwerska, 'W atmosferze wrogości' in Anna Wolf-Powęska (ed.), Polacy wobec Niemców. Z dziejów kultury politycznej Polski 1945-1989, pp. 45-93; Piotr Madajczyk, 'Polska myśl zachodnia w polityce komunistów polskich', Przeglad Zachodni 3, 53 (1997), pp. 15-36; Wacław Miziniak, 'Polityka informacyjna' in Wolf-Powęska, Polacy wobec Niemców, pp. 142-160; Jakub Tyszkiewicz, 'Propaganda ziem odzyskanych w prasie Polskiej Partii Robotniczej w latach 1945-1948', Przeglad Zachodni 4, 51 (1995), pp. 115-132.

96 Żolnierz-Osadnik, 14 April 1946. 
Such propagandistic narratives employed explicit references to medieval legends and knights' tales - the military settler was represented as an old-style hero with a sumptuous Polish moustache and a stern but honest Slavic countenance, a gritty warrior who never gives in to the forces of circumstance. According to one story reported on the pages of the newspaper Żotnierz-Osadnik ('Soldier-Settler'), the residents of a village decided to replace an out-of-favour chairman of the local chapter of ZOW, and found an ideal candidate: the sergeant they recruited had the surname Piast, the name of Poland's first royal dynasty. ${ }^{97}$

Available military documents such as internal communications show that the enthusiasm and ability that official propaganda ascribed to military settlers were greatly exaggerated. Propaganda was a tool of social engineering, but it also reflected a yearning for a prosperous, safe world inhabited by courageous and resourceful individuals. Meanwhile, many registration forms and reports gathered by the military indicate that the settlers were more concerned about the families they had lost in the east than about the 'revival' of the 'Recovered Territories' after their 'civilizational decline' under German rule. ${ }^{98}$

In the first years, a feeling of temporariness was characteristic among the majority of the western territories' new residents. Military settlers were no exception. They doubted the stability of the state border at the Oder-Neisse Line, applied themselves half-heartedly to their agricultural work, and wanted to return to their former homes. ${ }^{99}$ The situation was worsened by plunder and theft being carried out by the Red Army units stationed there: a large portion of estates had been emptied of equipment and livestock. Soviet soldiers stole mainly from Germans, but also targeted Polish settlers. ${ }^{100}$ 'Crops have been destroyed, cows and horses are being kept indoors because people are afraid they will be stolen,

97 Żotnierz-Osadnik, 1-15 December 1946. The mythology referring to Piast dynasty had been already in use in the nineteenth century and was later recycled by the communists. The so-called Piast concept (vs Jagiellonian concept) meant that the re-born Polish state should be based on its initial territories in the West because the country in the Middle Ages was believed to be ethnic Polish, democratic and strong. According to some legends, the forefather of the medieval dynasty, Piast was a modest and wise peasant.

98 Kersten, Osadnictwo wojskowe w 1945 roku, pp. 641-642; Dziurzyński, p. 78; Tadeusz Langner, 'Organizacja i przebieg osadnictwa wojskowego w powiatach słubickim i sulęcińskim w latach 1945-1946' in Przegląd Zachodni 1-2, 23 (1967), p. 97; 'Sprawozdanie Zarządu Głównego Związku Osadników Wojskowych za 5 czerwca - 5 lipca 1946', CAW IV 502.1.587, p. 38.

99 'Sprawozdanie ZG ZOW za 5 października - 5 listopada 1946', CAW IV.502.1.590, p. 368; 'Sprawozdanie z inspekcji przeprowadzonej w powiatach osadnictwa wojskowego 7-11 listopada 1946', CAW IV.502.1.346, p. 39.

100 Władysław Dinwebel, 'Wojskowa akcja osadnicza w powiecie Lwówek Śląski', Polska Ludowa. Materiały i studia 2 (1963), p. 33. 
and loitering soldiers go around demanding vodka,' stated one report directed at the military authorities. ${ }^{101}$

The day-to-day conditions experienced by military settlers were chaotic and unpredictable - far removed from any popular ideal of military efficiency. Soldiers had to deal with a variety of officials representing different and often competing institutions: the military authorities, civil administration and party. ${ }^{102}$ The situation was rendered more complicated by over-population, the absence of regulations on private property, and the eagerness of different social groups to take matters into their own hands. Military circles complained about civilian settlers, who had arrived earlier and taken better, less ruined plots of land. ${ }^{103}$ Settlers from central Poland were treated with particular distrust; it was widely believed that they had arrived with the principal aim of looting and taking the spoils back to central Poland. ${ }^{104}$ At the same time, soldiers drew attention to Germans who had not yet been resettled. The nuances of the new state's nationality policy were not clear to many military settlers; a part of the population had gained recognition as ethnic Silesians with local roots. A question that concerned the settlers was whether 'verified Germans' (i.e. officially recognized Silesians) had a right to return to the farmsteads that arriving Poles had already occupied. ${ }^{105}$

The soldiers' fears were not groundless. For example, in 1946 several thousand military settlers who had moved to the region of Opole and Kluczbork were forced to leave their new homes, because their original owners had been classified by the Polish authorities as Silesians and were permitted to repossess their land. Some of these soldiers moved to the nearby counties of Lwówek, Lubań and Zgorzelec. Here, however, the land had already been occupied, partly by civilian settlers. In order to find themselves a place to live, the soldiers travelled from village to village in search of civilians and attempted to enforce their eviction, relying on the 'evidence' provided by neighbours who claimed that these families already owned land in central Poland. ${ }^{106}$ Nonetheless, military and civilian settlers, alongside Germans who remained, were frequently forced to share single farmsteads. Numerous quarrels took place over nearly everything: houses, land, seeds for sowing, livestock, food, furniture and even cooking

101 'Sprawozdanie ZG ZOW za 5 lipca - 5 sierpnia 1946', CAW IV 502.1.593, p. 8.

102 CAW IV 502.1.587, p. 200; CAW IV 502.1.592, p. 42; CAW IV 502.1.593, pp. 7-9, 14, 15, 19, 20; CAW IV.502.1.590, pp. 468, 470, 473-475, 368; CAW IV 502.1.13, p. 160,161, 163.

103 Kersten, Osadnictwo wojskowe w 1945 roku, p. 657.

104 'Sprawozdanie ZG ZOW za 5 lipca - 5 sierpnia 1946', CAW IV 502.1.593, p. 6, 7.

105 CAW IV 502.1.593, p. 17.

106 Dinwebel, p. 39. 
utensils. Difficult compromises were only sometimes reached: 'in the morning, the civilian Baran collects milk from the cow, the military settler milks her in the afternoon, and the German family in the evening,' reported one satisfied representative of ZOW. ${ }^{107}$

Furthermore, a past in the Polish Armed Forces in the East was not a source of social prestige among Poles. According to a popular saying at the time, 'a patch here, a patch there, that's what commie soldiers wear' ('z przodu tata, $z$ tylu tata, to jest żotnierz demokrata'). ${ }^{108}$ Reports show that a soldier settler who complained about material conditions could expect from his neighbors responses such as: 'go to the people who told you to fight!' 109 or 'grab your machine gun and go to the forest!' ${ }^{110}$ A soldier decorated with the Cross of Valour complained that 'the mayor [wójt] and village elder [soltys] call him a Bolshevik Ukrainian.' Another soldier was told by his local mayor that 'your property is in the East, you are just a worker." ${ }^{111}$ Yet another settler with military honours had one cow and a family of seven to feed. Sharing a farmstead with a civilian settler, he complained that:

... the drunkard and plunderer [i.e. the civilian] allows him no share of the farm, doesn't let him bake bread, doesn't work in the field and persecutes his family - he even hit his daughter. He sold the grain and one ox that had been left by the Germans, and bought five pigs and a horse with the money, claiming that they were all his own. His wife said, 'if you served in the Jewish army, let the Jews give you some animals. ${ }^{\text {'112 }}$

In such situations, the activity of the Union of Military Settlers was not restricted to propagandistic encouragement of expressing support for the socialist regime (by e.g. participating in referendums and elections). It was also important that the organization provide help in settling into farmsteads, establishing agricultural cooperatives, distributing livestock and crop seeds, finding work in towns and cities, and alerting the civil and military authorities to any difficulties faced by military settlers.

107 'ZOW Okręgu Dolnośląskiego do Wojewody Wrocławskiego, 3 sierpnia 1946', CAW IV 502.1.590, p. 473.

108 Interview with P.B., July 2004.

109 'Protokół z pierwszego Zjazdu Przewodniczących Wojewódzkich i Powiatowych ZOW, 21 lipca 1946 r.', CAW IV 502.1.593, p. 24.

110 'Sprawozdanie ze Zjazdu Osadników Wojskowych Ziemi Lubuskiej, 23 października 1946', CAW IV 502.1.13, p. 163.

111 'ZOW Okręgu Dolnośląskiego do Wojewody Wrocławskiego, 3 sierpnia 1946', CAW IV 502.1.590, p. 473.

112 Ibid. 


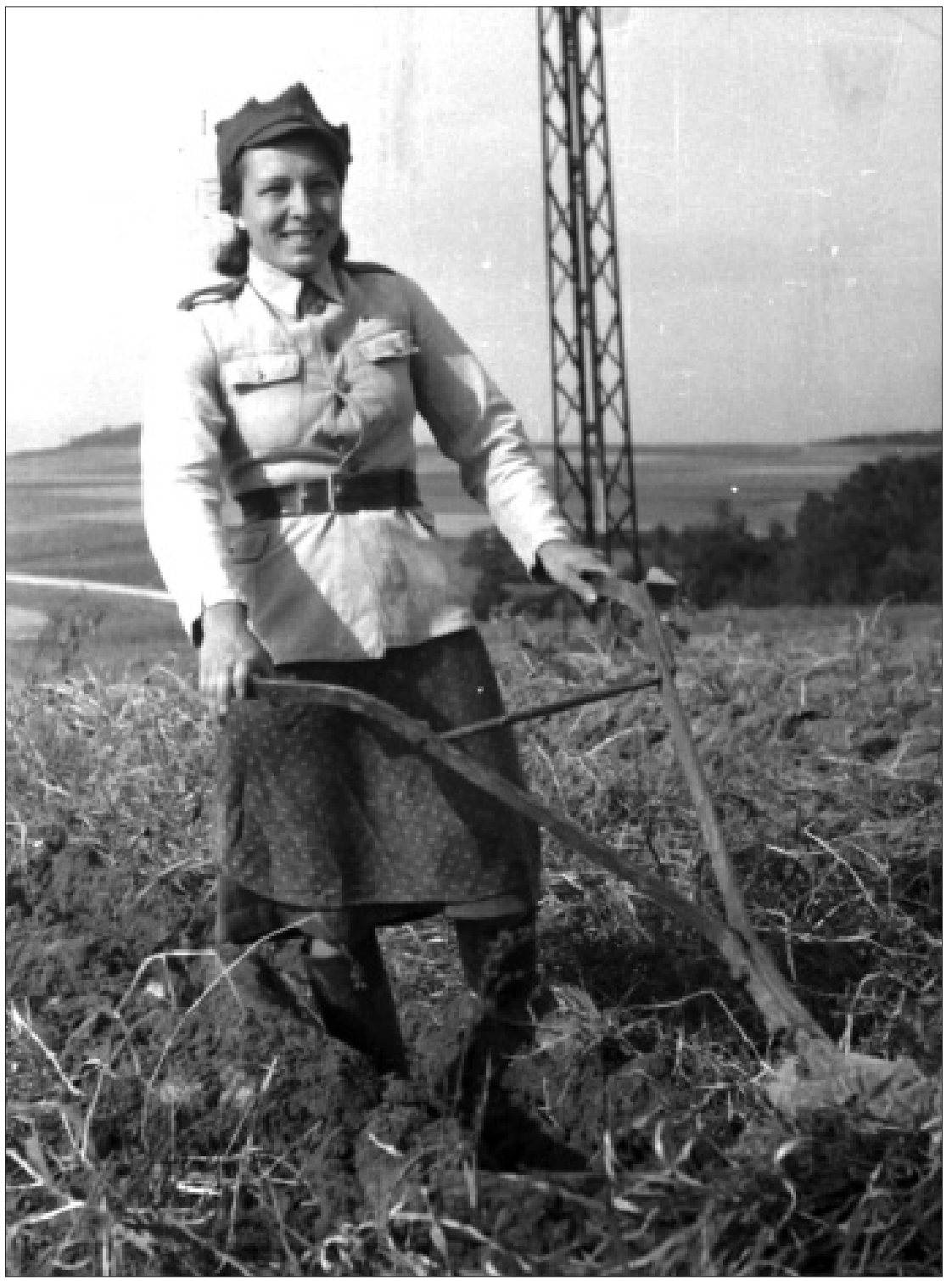

2.7 Propaganda picture of a former soldier of a female brigade of Polish Armed Forces ploughing the post-German territories, Platerowo, 1946. Photo by Dabrowiecki, National Digital Archives/Polish Press Agency. 
Both in the western regions and elsewhere in Poland, former communist partisans were more fortunate. Unlike Home Army fighters, concentration camp prisoners, Silesian insurgents and soldier settlers, they were integrated into the official structures of the nascent socialist state. For most of them, membership in a veterans' association was a background activity, or part of a broader mission to build a new social reality. Former soldiers of the Dąbrowski Brigade were among the most relied-upon groups in the new state: many were employed in the security organs and police, at various levels of the state administration, in the party apparatus, and the armed forces. ${ }^{113}$ An official of the Union of Dąbrowski Soldiers in Gdańsk justified his neglect of his administrative duties by appealing to the "mountain of work' he had to do at the Department of Public Security. ${ }^{114}$ Out of 23 members of this union in Kraków voivodeship, 18 were gainfully employed in 1949: of those 18 , ten worked in the state power structures or party administration, four at the regional department for security, one was a policeman, two worked at a local prison, and one was an official of the regional party committee; in addition, of the five individuals without a permanent place of work, two worked in some unspecified capacity along the 'party line'. ${ }^{115}$ Moreover, communist ex-combatants not only had their 'own' associations, including the Union of Dąbrowski Soldiers and the Union of Veterans of the Revolutionary Struggles, but also were encouraged by the party to join other organizations. Thus, especially after 1947, the activity of many communist partisans in all of the veterans' unions was directed at confrontation with other 'reactionary' groups.

\section{'The Soil Has Been Tilled': Towards the Forced Unification of Memory Groups}

The circles of former concentration camp prisoners quickly became the object of jealous attention from the authorities of the Polish Workers' Party, chiefly because they were an important section of the political clientele of the still existing Polish Socialist Party. 'This organization is not valued here', underlined the Secretariat of the PPR in January 1946. The party Secretariat thereafter sent 'strong comrades' who had experienced the Nazi camps (Jerzy Albrecht, Jan Izydorczyk and Pelagia

113 Jan E. Zamojski, ‘Interbrygadziści Republiki Hiszpańskiej - Po klęsce... Losy Polaków’ in Elda González Martinez and Małgorzata Nalewajko (eds.), Hiszpania-Polska: spotkania, Warszawa 2003.

114 'Dla komisji likwidacyjnej Zw. Dąbrowszczaków w W-wie', 17 March 1950, AAN, Grupa Akt ZBoWiD, 2, p. 68.

115 AAN, Grupa Akt ZBoWiD, 2, p. 90, 91. 
Lewińska) to represent the PPR at chief conferences and events organized by PZbWP. ${ }^{116}$

The communist party's desire to involve itself with the prisoners' union was the result of several pragmatic and ideological concerns. Firstly, the PPR's authorities had a vested interest in ensuring the eligibility of former prisoners of the pre-war Polish regime to join the union; they wanted the suffering of inter-war communists and the broad spectrum of wartime prisoners to have equal value. The Secretariat of the Central Committee decreed that 'the transformation of [PZbWP] into an organization for all political prisoners must become a tendency in the union's development. ${ }^{117}$ Putting the political inmates of the Polish prison at Bereza Kartuska (1934-39) ${ }^{118}$ and those of the Nazi concentration camps on an equal footing was one of many ways in which the pre-war Sanacja ${ }^{119}$ regime was delegitimized and the new communist government justified. Secondly, the treatment of PZbWP was consistent with the overall propaganda guidelines concerning the memory of the camps. The authorities recognized that the 'theme of wartime suffering' would absorb an undesirably large portion of society's attention, and that contemplation of the 'difficult and protracted days of the occupation' would result in unrest. The ideological guidelines for working with former camp prisoners therefore demanded that stories of hardship be 'reduced to a minimum', and the more positive fact of victory over Germany be emphasized. ${ }^{120}$ This was the origin of a narrative of the camps that came to dominate, in a more developed form, from the early 1950s onwards; according to this vision of the past, the camp prisoner was a hero who triumphed in fighting for a good cause. Thirdly, PZbWP was one of the main actors on the foreign policy scene - the organization was integrated into the structures of the international left-wing ex-combatants' movement, which in the 1940s was channelled through the International Federation of Former Political Prisoners (Fédération Internationale des Anciens Prisonniers Politiques, FIAPP; the federation had been founded at the same time as PZbWP, had its headquarters in Warsaw, and Józef Cyrankiewicz was a member of its governing body).

116 'Protokół nr 1 z posiedzenia Sekretariatu KC PPR, 12 stycznia 1946', in Kochański (ed.), Protokoły z posiedzeń Sekretariatu, p. 154.

117 Ibid.

118 A prison in Polesie province (today Belarus), founded to detain political opponents including many communists, who were viewed by the Polish state as a threat to security and social order. Internees were kept without formal charges for three months (with the possibility of prolonging the detention indefinitely). They performed penal labour under harsh conditions, which caused deaths among prisoners.

119 Sanacja (sanation) was an authoritarian political movement that came to power after the coup d'état (1926) by Józef Piłsudski.

120 Dmitrów, 'Pamięć i zapomnienie', p. 4; idem, Niemcy i okupacja w oczach Polaków. Poglady i opinie z lat 1945-1948, Warszawa 1987, p. 159. 
FIAPP had affiliates in Western Europe and had both welfare goals (e.g. applying pressure to governments to recognize special privileges for former prisoners) and political ones (such as the condemnation of penal methods used against prisoners in Western Europe, especially Spain and Greece). ${ }^{121}$ The PPR could not remain indifferent to this prominent role played independently by PZbWP. Finally, the prisoners' union was one of the key institutions that built ties between the regime and the Catholic priesthood. PZbWP had a number of clergymen in its ranks: priests who had been interned in concentration camps, especially Dachau. Priests initially joined the organization, in small numbers, because they were attracted by the material assistance offered to their families and the church. In time, the union began to create a more consolidated group of loyal clergy who were taken in by official pro-Soviet, anti-German, anti-American and anti-Vatican propaganda; since 1949 they had been called patriot-priests. ${ }^{122}$

The striving to subordinate former prisoners by uniting them with veterans' associations gained momentum around 1948, at the same time that public life began to undergo totalitarization. The communist party decided to merge all the unions into a single body, and also to subject them to strict ideological and economic control. After an intensive and highly politicized wave of verifications of associations' members in 1947 (which ensured that regional directorates were fully under the control of the party), the merger of unions began in 1948 with the decision to liquidate the Union of Military Settlers. ${ }^{123}$ At a congress on 25-27 September, ZOW was united with ZUWZoNiD; as already mentioned, the new organization was named the Union of Fighters against Fascism and the Hitlerite Invasion for Independence and Democracy. This act was badly received by both the military settlers, who were deprived of an institution that defended their interests, and the Home Army soldiers who sensed a threat to their (already weak) position. Indeed, 'verification' was carried on also in the new union - in effect, politically undesirable groups were removed.

All of the other associations were brought under the strict control of the PPR; directorates were changed and lustration was carried out. The general atmosphere of this period is conveyed by the minutes of meetings in early 1949. People spoke of 'screws being tightened', of being 'under the magnifying glass'; they discussed the 'removal of the speculating and reactionary elements' and being 'covered by the direct patronage' of the party.

121 'Międzynarodowa więź przyjaźni złączyła ofiary niemieckiego barbarzyństwa', Wolni Ludzie 3 (1947), p. 4, 5.

122 Jacek Żurek, Ruch 'księży patriotów' w województwie katowickim w latach 1949-1956, Warszawa 2009.

123 'Protokół nr 16 z posiedzenia Biura Politycznego, 6 maja 1948' in Kochański (ed.), Protokoły z posiedzeń Biura Politycznego, p. 207. 


\section{ZA}

Dnia 14 grudnia 1947 r. o godzinie 12-tej

W DOMU OSADNIKA WOJSKOWEGO (ul. Zwycięstwa Nr 122)

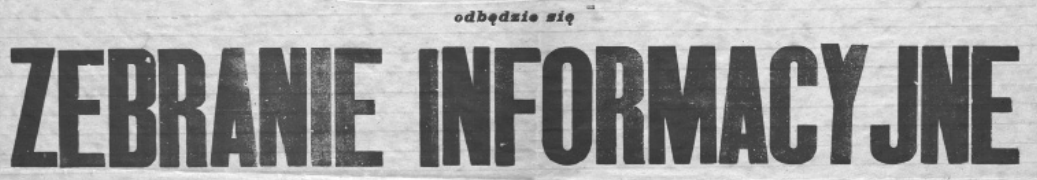

\section{UCZESTNIKÓW WALKI ZBROJNEJ O NIEPODLEGłOSĆ I DEMOKRACJE}

Z uwagi na donioslośc spraw, jakie będą omawiane - prosimy UCZESTNIKÓW OSTATNIE] WOJNY Z NIEMCAMI jak i UCZESTNIKÓW RUCHU PARTYZANCKIEGO W OKRESIE OKUIPACJI NIEMIECKIE] - o jaknajiliczniejsze przybycie

HASHO: "PIERWII W WALCE-PIERWSI W ODBUDOWIE KRAJU“ winno byó dowizạ katdego b. bojownika o wolnoś́ 1 demokracje ZARZAD ZWIAZKU UCZESTMIKOWW

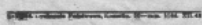
Oddział w Koszalinie

\section{Związek Uczestników Walki Zbrojnej \\ o Niepodległość i Demokracje KOEO PLESZEW}

W niedziele, dnia 29 lutego $1948 \mathrm{r}$. o godz. 15-tej odbedzie sie w Pleszewie w Hotelu Wiktoria

\section{ROCZNIE}

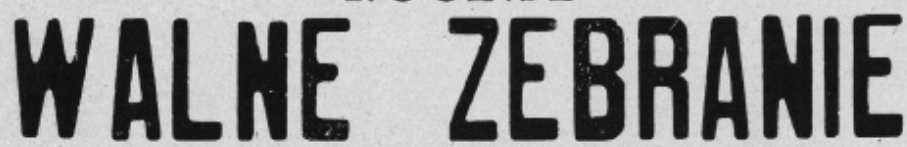

na które zaprasza się wszystkich uczestników Walki Zbrojnej $z$ niemcami.

\section{Za Zarząd Kota \\ J. Nolnak, sekretarz E Sroczyniski prezes}

Sympatycy mile wid; $i$ ni.

Udział członków obowiązkowy.

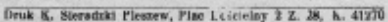

2.8 Announcements of meetings of ZUWZoNiD concerning the planned merger of veteran organizations, 1947/1948. National Library of Poland. 
In March 1949, the party cells within the PZbWP ordered the liquidation of local-level groupings $(\mathrm{kota})$ and demanded that hereafter meetings should be held exclusively at the county (powiat) level and above. The party activists campaigned for the hastening of measures to accept communist prisoners of Tsarism and Sanacja into the organization, and argued that the union should absorb other prisoners' association that were 'wandering in the wilderness' - in other words, smaller autonomous organizations such as the Association for the Preservation of Majdanek were to be brought under control. The party cells also announced the liquidation of the PZbWP's Council for Social Support; the union's material assistance initiatives were to be curtailed. Henryk Matysiak, a former political prisoner, member of the Main Directorate and office director of PZbWP (and over the course of the next twenty years, one of the key figures of ZBoWiD - he would become a full-time member responsible for propaganda), summarized these decisions as follows:

It is said that the soil has been tilled and resistance has been broken, and that now our main task is to assist the efforts of the party members within our union. Issues surrounding the commemoration of martyrs have become a secondary concern. A straightening of the political line has been put into effect. ${ }^{124}$

In June 1949, after the political merger of PPR and PPS that resulted in the United Polish Workers' Party (PZPR), the Political Bureau of the PZPR Central Committee took a final decision to merge all of the remaining associations into a single organization. ${ }^{125}$ Various names for the new organization were mooted, such as the 'Anti-fascist Union of Combatants', the 'Polish Union of Combatants', and the 'Union of Participants of the Struggle for Freedom and Democracy'. The words 'freedom' and 'democracy' were eventually identified as key terms, and the name 'Union of Fighters for Freedom and Democracy' (ZBoWiD) was settled upon. ${ }^{126}$

Publications from communist times declare that eleven former associations were brought together to form ZBoWiD - these unions were named at the Unification Congress in September 1949 as the apparent founders of the new organization. However, the most substantial archival document on the theme of the 'consolidation of brotherly organizations', indicated that other organizations were simply banned; it stated for instance the need 'on the margins of this process, to liquidate and remove from the register a number of local organizations', alongside 'a range of similar organizations that either carry

124 AZGZKRPiBWP 3, 3, p. 26.

125 'Protokół nr 25 z posiedzenia Sekretariatu KC PZPR z 20 czerwca 1949', AAN, KC PZPR, 2205 , p. 310.

126 'Brudnopis uchwały Biura Politycznego KC PZPR w sprawach organizacji społecznych z 23 czerwca 1949', AAN, KC PZPR/XXVI, 6, p. 8. 
out no actual activity, or were founded as fronts for anti-democratic activity.' ${ }^{127}$ This document, forwarded in May 1949 to Stanisław Matuszewski of the PZPR Central Committee (who, at the time, was responsible for the practical aspects of the centralization of social life), ${ }^{128}$ also stated that 'the political influence of the Party' was 'relatively good' in six of the most important organizations thanks to the process of 'verification, as a result of which the class enemy and parasitic elements have been removed'. The only ideologically unsafe organization, according to this report, was the Union of Wielkopolska Insurgents, who 'before the war were a hotbed of political conservatism, and some of those nationalist conservatives remain members of this union to this day. ${ }^{129}$ It was also suggested that only a third of the members of ZOW had decided to apply for membership of the newly consolidated Union, the rest were conspicuous in their 'tendency to remain faithful to the traditions and customs of exclusively defending the interests of the military settlers, in the worst meaning of this word, such that they even openly speak out against the government's [collective farming] policies in the countryside. ${ }^{130}$ This document appears to avoid drawing even the most basic distinctions between different memory groups; it states merely that 'they have a common social base'. Preparations for the Unification Congress involved, above all, mobilizing party activists and compelling the (already compliant) directorates of associations to declare their co-operation in the merger, discontinue their economic activity and announce the impending changes to their members throughout the country. The actual dissolution of the organizations' regional structures was initiated after the Unification Congress, in 1950.

All in all, in the first two years after the war, the activity of veterans and former political prisoners was concentrated on commemoration and social assistance, but it was nonetheless both substantial and pluralistic. The limits of institutional autonomy had not yet been precisely defined, and that made it possible to articulate diverse group interests and identities. However, the largest associations avoided organizational affiliation with specific wartime formations, claiming instead to represent 'all' partisans, soldiers or prisoners. In the years 1948-49, the state authorities began to suppress independent social initiatives. Centralization implied a denial of the need for different associations and imposed

127 'Załącznik nr 21 do Memoriału w sprawie uregulowania masowych organizacji społecznych i innych stowarzyszeń wraz z naświetleniem aktualnej sytuacji na tym odcinku z 27 maja 1949’, AAN, KC PZPR/XXVI, 6, p. 40.

128 'Uchwała Biura Politycznego KC PZPR w sprawach organizacji społecznych', 23 June 1946, AAN, KC PZPR/XXVI, 6, p. 1, 2.

129 Ibid., p. 41.

130 Ibid. 
a monolithic interpretation of recent history. These processes intensified in the following years within the monopolistic union, ZBoWiD; the creation of this organization was an essential policy aim of the communist authorities that had broad and long-term consequences, both for the politics of memory and for the expression of veterans' and ex-prisoners' interests. 
Joanna Wawrzyniak - 978-3-653-99681-4

Downloaded from PubFactory at 01/11/2019 11:05:35AM

via free access 


\section{Chapter 3 \\ The Myth of Victory over Fascism (1949-55)}

By the end of the 1940s, on both sides of the Iron Curtain, the elites in power had not only accepted the Cold War, but they had turned it into a philosophy of rule. ${ }^{1}$ Only a few years after the end of the Second World War, the idea of the enemy had become a key element of propaganda in the states of the newly divided world. Stalin condemned 'imperialism', whose main representative was the USA, and mixed the rhetoric of the pre-war left-wing pacifist movement with wartime patriotic agitation. In this way, the ideology of anti-fascism survived the fall of Hitler and Nazi Germany. Anti-communist ideologists in the West reciprocated in kind: a key component of the Truman doctrine was the belief that the mistakes of the Munich Agreement (1938) should not be repeated, and the Soviet Union was now accused of having taken the place of Nazi Germany on the political map of Europe. At the same time, the logic of the Cold War began significantly to affect social and economic relations within the countries of Central and Eastern Europe.

In the propaganda of the communist authorities in Poland, the memory of the bygone war and the fear of another ensuing conflict were integrated into a narrative that propounded the absolute necessity of communist power. This chapter shows that the rhetoric of Cold War agitation, with its two principal metaphors of 'the fight for peace' and the 'national front', were combined with the myth of victory over fascism, the foundational myth for the entire Soviet system as well as communist Poland. This was a myth that invoked power and glory, sought to legitimize the new political order at both national and international levels, and also demanded constant mobilization, on the grounds that full victory had not yet been achieved. The myth was embodied in the symbolism of death and blood, in ritual commemorations performed at former camps and sites of battle, and in published histories of the war. It was also, importantly, a mechanism for the organization of social reality. As increasing emphasis was placed on the propaganda of permanent struggle, practical initiatives undertaken by ZBoWiD, such as social support schemes, were abolished. The title of a 'fighter' (bojownik), as featured in the

1 François Furet, Le Passé d'une illusion. Essai sur l'idée communiste au XX siècle, Paris 1995, pp. $455 f$. 
organization's name, became a symbol for an as-yet unfinished war in service of a great cause: freedom and peace. The intensification of Cold War propaganda heralded the onset of unfinished time: fulfilment could only be brought by the future.

\section{Setting the Stage}

\section{The Unification Congress}

Veterans and former prisoners were necessary as living symbols of war, as evidence that supported the version of history being told by the authorities. The Unification Congress at which ZBoWiD was founded was held on 1-2 September 1949 , to coincide with the tenth anniversary of the Nazi invasion of Poland. The Congress was organized by the department of mass propaganda of the Party Central Committee, and orchestrated as a large-scale demonstration of "peace and patriotism'. ${ }^{2}$ It was designed to cement a dominant narrative of the Second World War, and show the strength of the communist movement and of the left-wing parties of Western Europe. These aims were expressed in the symbolic apparatus of the event, as well as in speeches by state and party officials and foreign delegates representing a range of bodies united under the banner of FIAPP. ${ }^{3}$

On the day before the start of the Congress, the assemblies of several associations were held in Warsaw, where each of these organizations declared their willingness to be brought together as a new, unified body. A rally was held in the evening on Victory Square (in the inter-war and today, Piłsudski Square) in the centre of Warsaw, during which wreaths were placed at the Tomb of the Unknown Soldier by representatives of the Congress's presidium, FIAPP and delegates of the 'fighters for freedom and democracy' from the USSR, Czechoslovakia, Germany, France, Italy, Bulgaria, Greece, Hungary, Spain, Romania and Yugoslavia. After honouring the dead and marking the occasion with the Polish national anthem, the delegates set off on a march to the Brotherhood in Arms monument, ${ }^{4}$ across

2 'Instrukcja do sekretarzy i kierowników wydziałów propagandy komitetów wojewódzkich', AAN, PZPR KC, VIII, 68, p. 4.

3 'Notatka do Sekretariatu KC PZPR ws. Kongresu Zjednoczeniowego Organizacji Bojowników z Faszyzmem, Byłych Więźniów Politycznych oraz kampanii w związku z dziesięcioletnią rocznicą klęski wrześniowej', AAN, PZPR KC, VIII, 68, p. 8.

4 The Brotherhood in Arms monument (see figure 3.1), designed by a group of Polish and Soviet artists, was unveiled twice: in 1945 (gypsum version) and 1947 (bronze version). The main group presents three Red Army soldiers in fighting poses, beneath which are the figures of two Polish and two Soviet soldiers jointly keeping symbolic guard. The 
the Vistula River. There, the Polish and Soviet anthems were heard. Guards of honour were held at numerous sites of grave loss of life, next to monuments and plaques. ${ }^{5}$ Foreign guests gave speeches at mass meetings organized at ten selected factories in Warsaw. Józef Cyrankiewicz, the Chairman of the Council of Ministers, organized a reception for the delegates, and President Bolesław Bierut personally greeted each of them.

The Unification Congress was held in the main building of the Warsaw University of Technology, where almost 1,500 people gathered. The presidium table was decorated with two unsheathed swords, the symbol of the Battle of Grunwald (1410) and of victory over the Germans (see figure 3.3). The honorary chair of the proceedings was Colonel Frédéric-Henry Manhès, a member of the French resistance, former prisoner of Buchenwald, and the chairman of FIAPP. The sessions were chaired by Józef Cyrankiewicz. An address was given by Franciszek Jóźwiak, who accented the unique historicity of the occasion: 'we are living on the threshold of two eras in the development of humankind: the epoch of degenerate capitalism which is suffering ever greater defeats, and the new epoch which is fast emerging, driven by the power of the working people. ${ }^{\prime 6}$ Over the course of two days, several dozen speakers took to the floor: representatives of the Polish state, members of veterans' and victims' organizations, and delegates whose wide variety of backgrounds was held to reflect the breadth of social support for communist power. Amongst the speakers were: a priest who recalled the 'Gehenna of Catholic priests in German death camps'; mothers 'speaking out against war'; a university professor; a miner from Silesia who represented the 'prisoners of Bereza Kartuska ${ }^{7}$ and the victims of the Sanacja regime'; Wanda Jakubowska, the director of the film 'The Last Stage' (Ostatni etap; 1947) about Auschwitz; a textile worker who had been a 'prisoner of the Hitlerite death camps'; a 'smallholder peasant' (and also a 'former soldier of the AK'); a seven-person delegation from the General Karol Świerczewski Corpus of Internal Security Cadets; and also a 'representative of bloodied, fighting Greece. ${ }^{8}$

monument has been mockingly referred to as the 'four sleepers and three fighters' by residents of Warsaw, a name that has an additional irony considering the Red Army's lack of assistance to Polish forces during the Warsaw Uprising of 1944. In 2011 the monument was removed in connection with major building works in the square where it was located. Heated debates continue to this day about whether it should be returned.

5 AAN, PZPR KC, VII, 2672, p. 43.

6 Cited in: W. Garncarczyk, 'Byliśmy pierwsi w walce o Nową Polskę - będziemy pierwsi w szeregach Jej budowniczych', Za Wolność i Lud 2 (1949), p. 23.

7 See footnote 118 in Chapter 2.

8 Za Wolność i Lud 2 (1949), p. 24. 


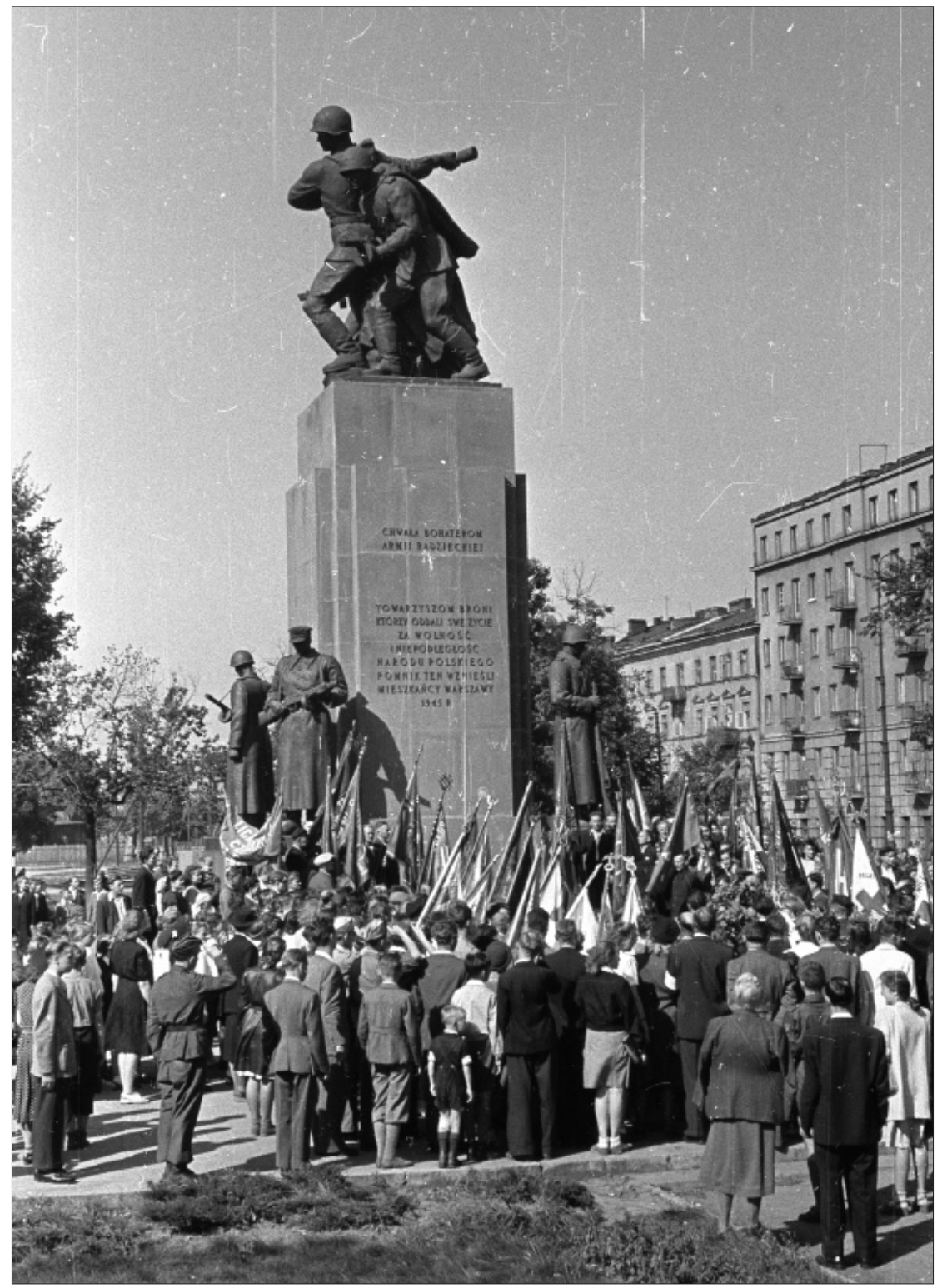

3.1 Ceremony at the Monument to Brotherhood in Arms, on the fourth anniversary of the liberation of Warsaw's Praga district. September, 1948, Warsaw. Photo credits unknown, Polish Press Agency. 


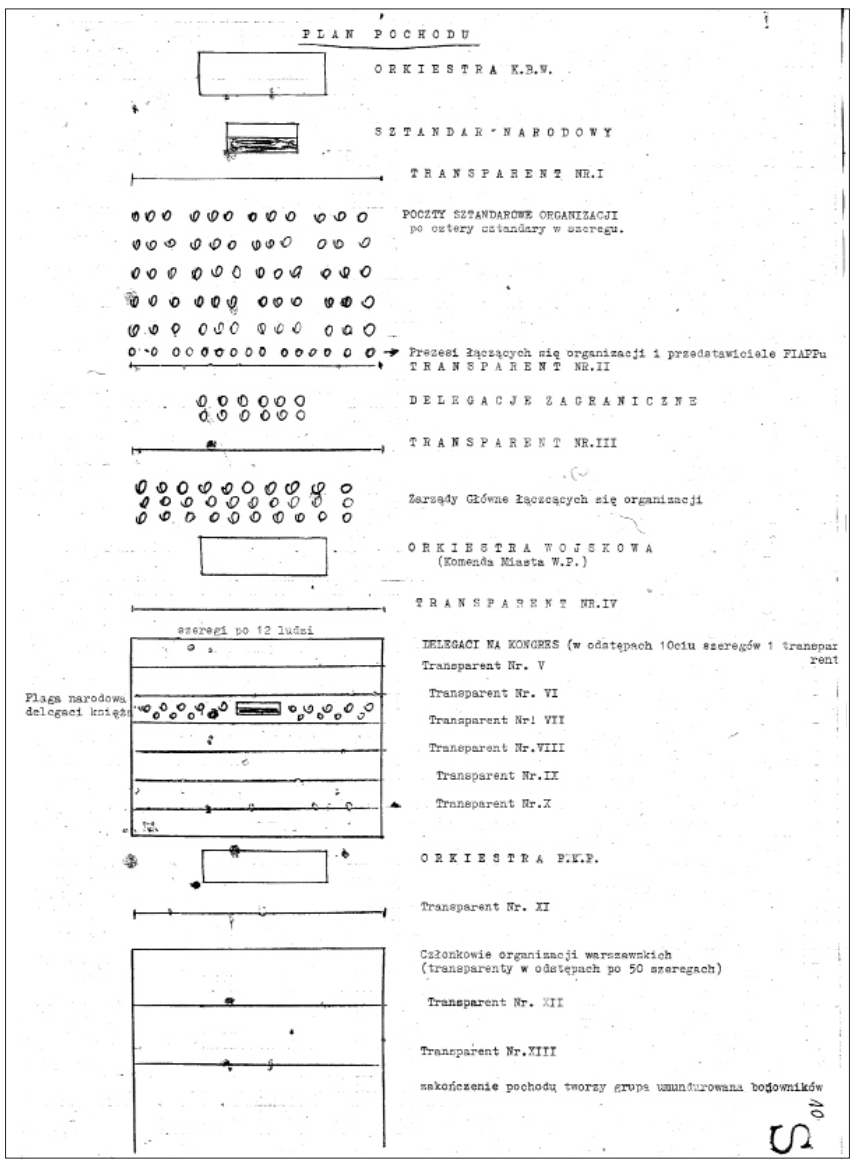

3.2 Plan of the demonstration of support to the Unification Congress of veterans and former prisoners organizations, 31 August 1949, drawn in Department of Propaganda of KC PZPR. Captions on banners run: I 'Long live Congress of ZBoWiD', II 'Long live FIAPP', III 'United in keeping guard over independence, people's democracy, and peace', IV 'Fighters for Freedom and Democracy in the front lines of soldiers and builders of People's Poland', $V$ 'Honour and glory to the fighters fallen for the case of Independence and People's Democracy', VI 'Vatican and Prussian politicians: keep your hands off our Regained Territories', VII 'September 1939: never again!', VIII 'September 1939: never again! Polish-Soviet Alliance guarantees lasting peace and independence', IX unknown, $X$ 'Formerly with arms, today with trowels: we keep fighting for Poland Fair and Mighty', XI 'The society will protect widows and orphans of fighters for Freedom and Democracy', XII 'Let's make our People's State stronger, better to protect Peace, Freedom and Achievements of the Polish Nation', XIII 'Fighters for peace and freedom for nations: unite!' $A A N, K C P Z P R$, VII, 2672, p. 10. 
The participants of the Congress received a special inaugural issue of a new veterans' journal, tellingly named Za Wolność $i$ Lud ('For Freedom and the People'). The journal presented, in shortened form and with illustrations, arguments for the historical legitimacy of the rule of the Polish communists. Authors described the pre-war political make-up of Poland using dark undertones: nearly all members of the pre-war ruling classes had allegedly supported fascism, the logical and final outcome of capitalism. The oppressed class, a large majority of pre-war Polish society, had gained its self-consciousness during the Second World War, which was presented as part of the revolutionary narrative. The Polish Workers' Party had taken up the struggle of 'miners and steelworkers, textile workers and railroad workers, teachers and artists, peasants and the working intelligentsia.' However, the victory over fascism and with it, the birth of a new Poland - would have been impossible without the participation of the Red Army; only thanks to its exceptional assistance and the 'bonds of brotherly kinship' between the Polish and Soviet soldier was it possible that in May 1945, "the [Polish] white-and-red flag flew over Berlin next to the red of the Soviet Union. ${ }^{9}$ Blood sacrifice and victory gave legitimacy to the rule of the Polish communists, who had gained their authority through the declaration of the July Manifesto of the pro-Moscow Polish Committee for National Liberation (1944) ${ }^{10}$. Under a large photograph of Bolesław Bierut, placed on one of the opening pages of Za Wolność $i$ Lud, were printed fragments of his speech 'to the Polish Nation on the occasion of the Day of Poland's Rebirth, July 22, 1949.' ${ }^{11}$ The name of this holiday as the day of 'Rebirth', on the anniversary of the declaration of the July Manifesto, shows the specific ways in which Communist rhetoric was mixed with Christian, messianic, and nationalist elements.

Participants of the Congress were made to understand that - with the exception of the country's 'rebirth' - the final goals towards which they had fought during the Second World War had not yet been achieved. Although the 'wheels of history' had already been set in motion and could no longer be stopped, further effort was required to fulfil the laws of history: both in Communist Poland and throughout the world, work was needed to 'build socialism and peace.' 'Building' was equated to the 'fight' against the relics of capitalism - now represented by American imperialism and its allies - and the struggle against capitalism was also a fight for peace, which could only prevail in a socialist system.

9 Ibid., p. 13.

10 See footnote 34 in Chapter 2.

11 Ibid., p. 3. 


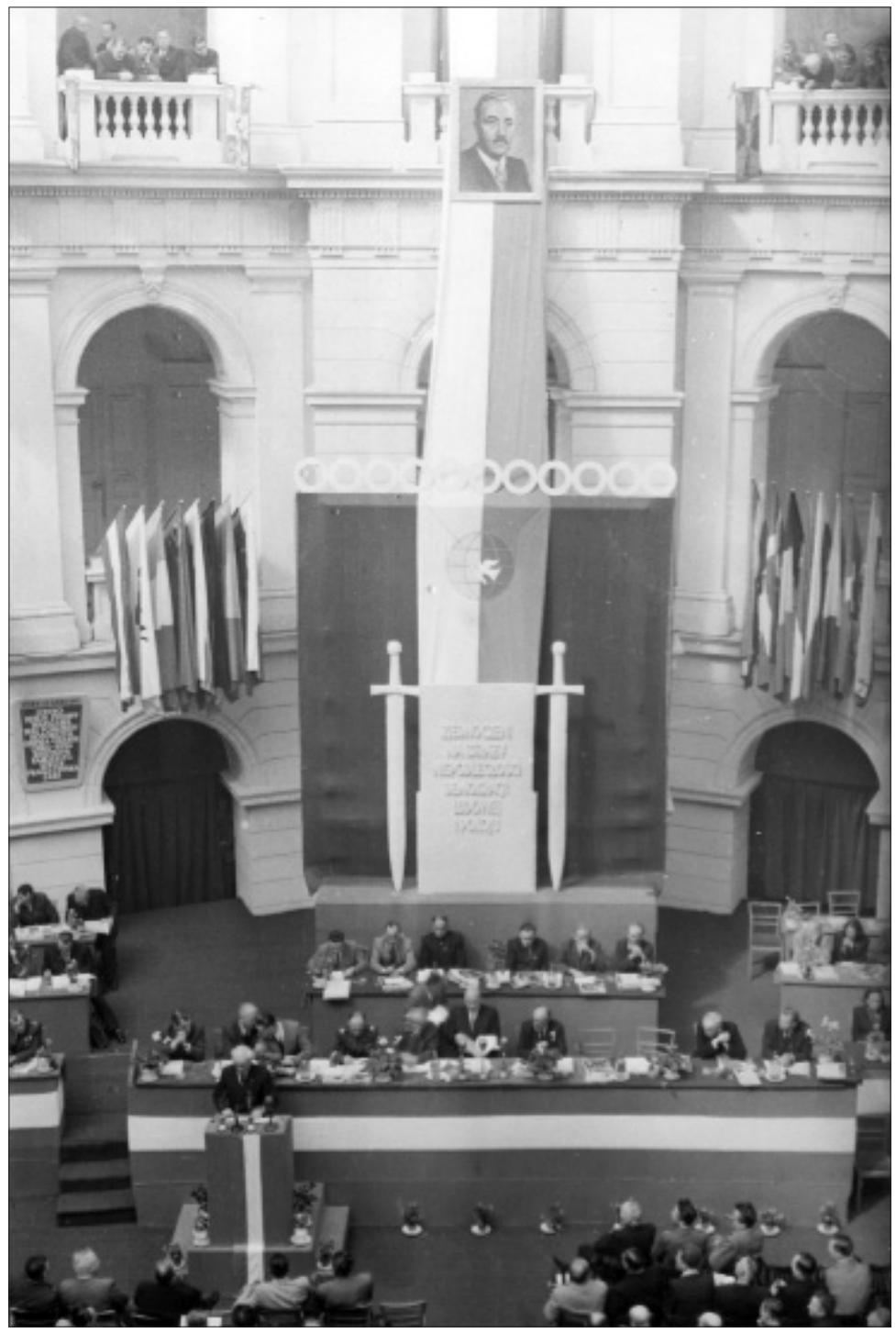

3.3 Decorated backdrop in the hall of the University of Technology during the Unification Congress. The two swords symbolize the victory over the Knights of the Cross in the Battle of Grunwald (1410) and, by extension, over Germany. The caption between the swords runs: 'We stand united guarding Democracy and Independence of People's Poland', Warsaw, September 1949. Photo by Wojciech Konradzki, National Digital Archives/Polish Press Agency. 
The slogan of a 'fight for peace' became one of the ideological foundations of the new organization. 'We unite at a time when the battle is escalating between the forces of peace and democracy, led by the Soviet Union, and the forces of imperialism, which are planning to unleash a new war of conquest,' declared the ideological manifesto of ZBoWiD. The Congress sent out four communiqués. Two of these were addressed, respectively, to the Soviet Committee for the Defence of Peace and the chairman of the World Peace Council, Professor Frédéric JoliotCurie. ${ }^{12}$ The other two, sent to Bierut and Stalin, contained assurances of the organization's readiness to defend the freedom and peace. Similar formulations were present in the majority of speeches and texts.

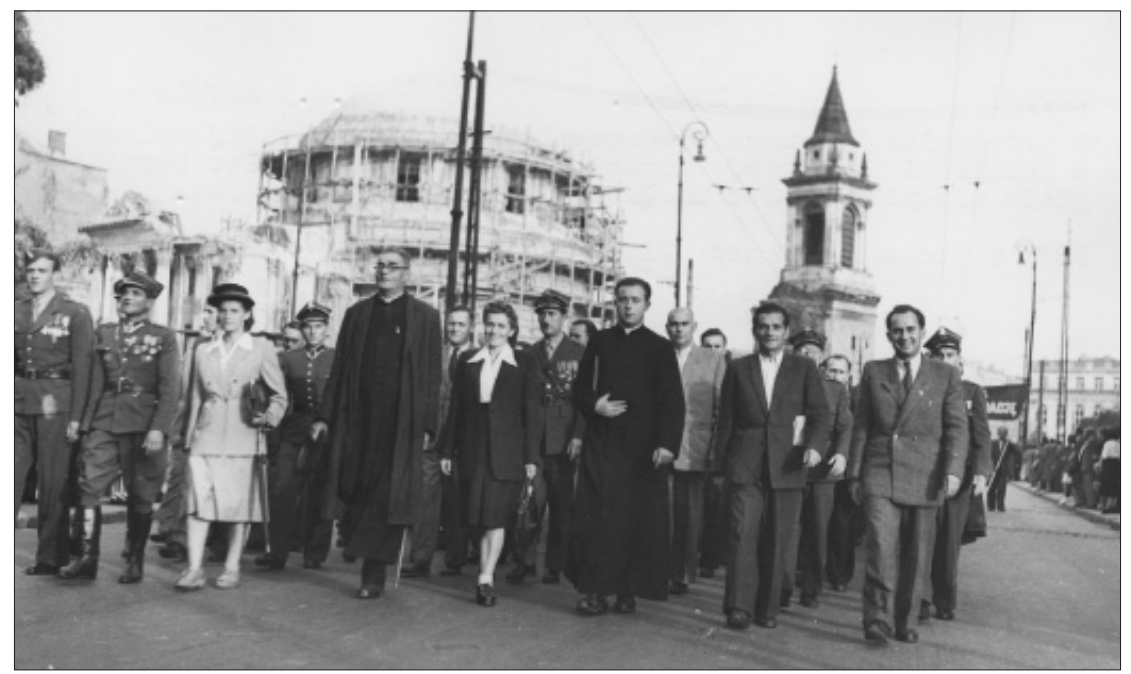

3.4 Delegates to the Unification Congress after wreath laying ceremony at the Tomb of the Unknown Soldier, 31 August 1949. Photo by Dąrowiecki, National Digital Archives/ Polish Press Agency.

What role was the Unification Congress designed to play, according to the intentions of its organizers? Undoubtedly, its role was instrumental: the Congress dealt with formalities such as the new union's statute and power structure. ${ }^{13}$ The Congress

12 Kongres Zwiazku Bojowników o Wolność i Demokrację, Warszawa 1 IX 1949, Warszawa, n.d., pp. $7 f$.

13 The presidium of the Supreme Council, a 100-person body with de jure authority over the Main Directorate, was composed of: Józef Cyrankiewicz as chairman, alongside Zygmunt Balicki, Józef Niećko, Eugeniusz Szyr and Jan Grubecki. The presidium of the 
also brought to an end the process of subordinating all of the veterans and former political prisoners to the state, which had begun in 1948 with the merger of ZOW and ZUWZoNiD. Additionally, it was an attempt to 'manage culture', organized in accordance with Soviet models. It offered a single language in which Poles could talk about their experiences of the Second World War in public.

The vision of history presented at the Congress provided a black-and-white image of allies and enemies, as well as interpretations of the aims of war and the meaning of wartime suffering. The struggle against 'fascism', broadly defined, was the only purpose of war. Martyrdom and heroism were conceptualized only in terms of class interest. Amongst the many symbols used during the Congress, the commemorative date that provided the pretext for the meeting is of particular interest: the tenth anniversary of the Nazi invasion of Poland, an event that was presented as a sign of the betrayal of the pre-war ruling elites and their 'collaboration' with the Third Reich. The choice of this date for a congress of war veterans could, arguably, be seen as somewhat perverse. It is unclear whether it was chosen specifically, or as a result of circumstance, e.g. because it was the only date with Second World War resonance available to the Central Committee officials who were hurrying to fulfil the directives of the Political Bureau. No matter what the motivation was, the interpretation of this anniversary served to delegitimize the pre-war Polish authorities and the efforts of all groups who were identified with them, including the Home Army and Polish Underground State. The vision of history provided by the communists made it unambiguously clear that communist rule was legitimate. Celebrating the fall of the pre-war state, the Congress also celebrated the pre-history of the birth of People's Poland.

Above all, however, the Congress was a mechanism for bringing about increased indoctrination in the new political order. It projected a model of social relations that was demanded by the ruling authorities, both at the international and domestic levels. The route of the march from the Tomb of the Unknown Soldier to the Brothers in Arms monument was a demonstration of Poland's dependence on the USSR. The crowds that gathered at the event and the individuals who gave speeches did not so much convey the size and significance of the wartime leftist resistance movement as express support for the communist authorities. In this model, all other sources of political authority were deemed to be redundant, including the Polish government-in-exile, the Catholic Church, and the anticommunist underground movement.

Main Directorate, which - as subsequent years showed - wielded de facto power over ZBoWiD, was composed of: Franciszek Jóźwiak (chairman), Wacław Rózga (first deputy chairman), Wilhelm Garncarczyk (second deputy chairman), Józef Passini (secretary) and Jerzy Jodłowski (treasurer). 


\section{Fighters for peace}

The propaganda of the Cold War formed the most important context for the functioning of ZBoWiD in subsequent years. The oxymoron of a fight for peace was connected to the concept of a 'fighter', as enshrined in the name of the organization. A fighter was different from a veteran, who was merely a former soldier. Franciszek Jóźwiak, in line with the spirit of the military propaganda of the day, warned union members against 'resting on the laurels of past deeds.' In his notes for the editors of Za Wolność i Lud, he emphasized that 'our magazine should be filled with references to the fight for peace, but not in a pacifist manner - the fight for peace must always be underlined - the fight for peace is a way of assuring the defensive readiness of the country. Peace must be won, it does not come by itself.' ${ }^{14} \mathrm{He}$ stated that fighters for freedom were destined to 'expose false American propaganda', precisely because they had participated in the war and had been prisoners of the camps. ${ }^{15}$ In a different speech, he appealed:

Colleagues and friends in the fight for peace, former partisans and prisoners of the Hitlerite camps, wherever you are today, continue the fight for a better and happier peaceful life! No matter where you are - in Bombay or Barcelona, Hamburg or Rome, London or Washington - we are all together in this struggle against imperialism, in this fight for peace. We are with you. ${ }^{16}$

In dozens of articles and published speeches, the magazine Za Wolność i Lud presented a polarized, Manichean vision of a primordial battle between two forces - good and evil:

Two sides are in conflict throughout the entire planet, of which one, composed of hundreds of millions of people, thirsts for peace, for the freedom of peoples and the welfare of the working individual. The second side - a league of exploiters and their servants - desires world domination for the dollar, the perpetuation of exploitation, and new, ever-increasing profits for the merchants of death. ${ }^{17}$

The hegemon of the world of evil was the USA, or to be more precise, the American ruling classes - 'the leaders of Wall Street', the 'idolators of the atom bomb', who were ready to plunge mankind into a 'sea of blood, destruction, ruin and crime.' Franciszek Jóźwiak made references to the Second World War in his address to

14 'Protokół z posiedzenia Prezydium ZG ZBoWiD', 31 July 1950, AZGZKRPiBWP 3, 67, p. 30 .

15 'Protokół z rozszerzonego Plenum ZG ZBoWiD, 24 lutego 1951', AZGZKRPiBWP 3, 29, p. 58; see also 'Protokół z rozszerzonego Plenum ZG ZBoWiD', 1 September 1951 [a speech by Stanisław Kiryluk], AZGZKRPiBWP 3, 30, p. 18.

16 'Referat gen. "Witolda". IV rozszerzone Plenum ZG ZBoWiD', 20 June 1952. AZGZKRPiBWP 3, 31, p. 58.

17 'Deklaracja ideowa' in Kongres Związku Bojowników, p. 16. 
the plenum of the Main Directorate of ZBoWiD in February 1951, comparing the brutality of the USA with Nazi wartime atrocities. Meanwhile, he presented the threat of the outbreak of a new war as a logical consequence of the striving of imperialism towards world domination:

Never mind that tears have not dried after the sufferings and tortures of the war; that the ash of the victims burned in crematoria and gas chambers has still not cooled; that the wounds received from Hitlerite fascism have still not healed. A new occupier, this time American, is sharpening its wolf-like claws for the conquest of the world..$^{18}$

Western Europe and Asia were likewise presented as being on the receiving end of American deceit. The theme of Korea, then at war with the USA, was especially prominent:

Can you imagine what this country would look like if peace and freedom had been achieved in Asia? It would be one giant recreational park for the Far East. There would be a house of workers' health here, a children's colony there, and high up in the mountains, a retreat for writers and scholars ... Miners from Manchuria and metal-workers from Pyongyang would sunbathe here, and in this little gulf would be a swimming area. ${ }^{19}$

This vision, according to the editors of Za Wolność $i$ Lud, came from the French left-wing journalist Yves Farge, speaking to a travel companion whilst on a visit to Korea. Eight years after the end of the Second World War, a magazine aimed at Polish veterans devoted more attention to conflicts in Asia than to the situation in Poland, presenting not only oriental fantasies such as that by Farge, but also, frequently, more brutal pictures. In January 1953 the editors cited a statement by Kim Yen Sun at the Congress of Peoples in Vienna:

In all places where the foot of the American soldier leaves a trace, there will be mass graves as a testament to his crimes. American soldiers forced one of our mothers to eat the eyeball of her own child. A pregnant woman had her arm and leg cut off, then they ripped apart her midriff, pulled out the child from inside her, and quartered the foetus. ${ }^{20}$

At the same time, ZBoWiD stoked the flames of anti-German sentiment by organizing rallies against the 'remilitarization and fascization of West Germany.' Protesting communiqués were also sent to the representatives of Western nations and the UN. Arguments revolved around the experience of the Second World War. Franciszek Jóźwiak stated:

18 'Przemówienie tow. „Witolda” na posiedzeniu plenarnym ZG ZBoWiD', 24 February 1951, AZGZKRPiBWP 3, 29, p. 8.

19 Tadeusz Kowzan, 'Wolność i pokój - znaczy człowiek. Ze wspomnień o Yves Farge’u', Za Wolność i Lud 5 (1953), p. 17, 18.

20 Anon., 'Na nowym etapie', Za Wolność i Lud 1 (1953), p. 3. 
Hitler's officers have been released from prison to head newly founded divisions. The criminals of Auschwitz, Treblinka and Majdanek have once again found themselves at the same table as the power-wielders of yesterday and today. Moreover, in West Germany, the fascization of political and economic life is under way clearly and without any scruples, whereas the supporters of peace and the democratic unification of Germany, youth organizations and political groups who disagree with Adenauer's politics are subject to brutal terror. ${ }^{21}$

The other side of this Manichean division of the world was the USSR - the 'fatherland of the proletariat' and 'guarantor of world peace'. ${ }^{22}$ Months dedicated to the deepening of Polish-Soviet friendship played an important role in the ZBoWiD calendar: the anniversary of the October Revolution (1917) was celebrated ritually, as was the anniversary of the Battle of Stalingrad (1942-43), a symbol of the glory of the Red Army. A constant motif of propaganda - the USSR as the guarantor of Poland's western border - was expanded to embrace the necessity of cooperation with the GDR, a buffer against West Germany. The citizens of the GDR were recognized as being of correct class origin, and they were relieved of the odium associated with Nazi crimes - as a result, the word 'German' was avoided in references to the Nazis, the words 'fascist' and 'Hitlerite' being preferred instead. The guidelines for the ZBoWiD badge design competition included an important formulation: 'the badge should have an antifascist message, not an anti-German one. ${ }^{23}$ (See figure 3.5). Representatives of ZBoWiD frequently met with representatives of the GDR's counterpart, the Association of Persons Persecuted by the Nazi Regime (VVN). ${ }^{24}$ These meetings took place at various events, for example at anniversary commemorations held at former camps, or at the border town of Gubin-Guben.

The guiding principle of a fight for peace was visible in the majority of the activities of ZBoWiD. The organization participated in the gathering of signatures in support of the Stockholm Appeal (1950), which called for a ban on nuclear weapons, and collected gifts for Korean children. Henryk Matysiak, speaking at a meeting in February 1951, gave detailed recommendations concerning the representation of history: 'we must organize meetings with the former fighters of the Dąbrowski

21 'Przemówienie tow. "Witolda" na posiedzeniu plenarnym ZG ZBoWiD', 24 February 1951, AZGZKRPiBWP 3, 29, p. 23, 24.

22 'Zadania ZBoWiD na obecnym etapie wygłoszone na Plenum ZG ZBoWiD 1 września 1951 przez S[tanisława] Kiryluka', AZGZKRPiBWP 3, 30, p. 25, 26.

23 'Protokół z posiedzenia Prezydium ZG ZBoWiD, 10 listopada 1949', AZGZKRPiBWP 3, 69 , p. 21.

24 In 1953, VVN was dissolved and turned into the Committee of Anti-fascist Resistance Fighters (Komitee der Antifaschistischen Widerstandskämpfer, KdAW). This transformation was accompanied by an ideological and anti-Semitic purge. See: Jeffrey Herf, Divided Memory: The Nazi Past in the Two Germanies, Cambridge, MA 1997, pp. 106-161. 
brigade, so that they can explain to the youth how, by fighting in Spain [in the Civil War, 1936-39], they were also fighting for our freedom, and how the Koreans and Chinese today are fighting against imperialism also to protect our interests. ${ }^{25}$
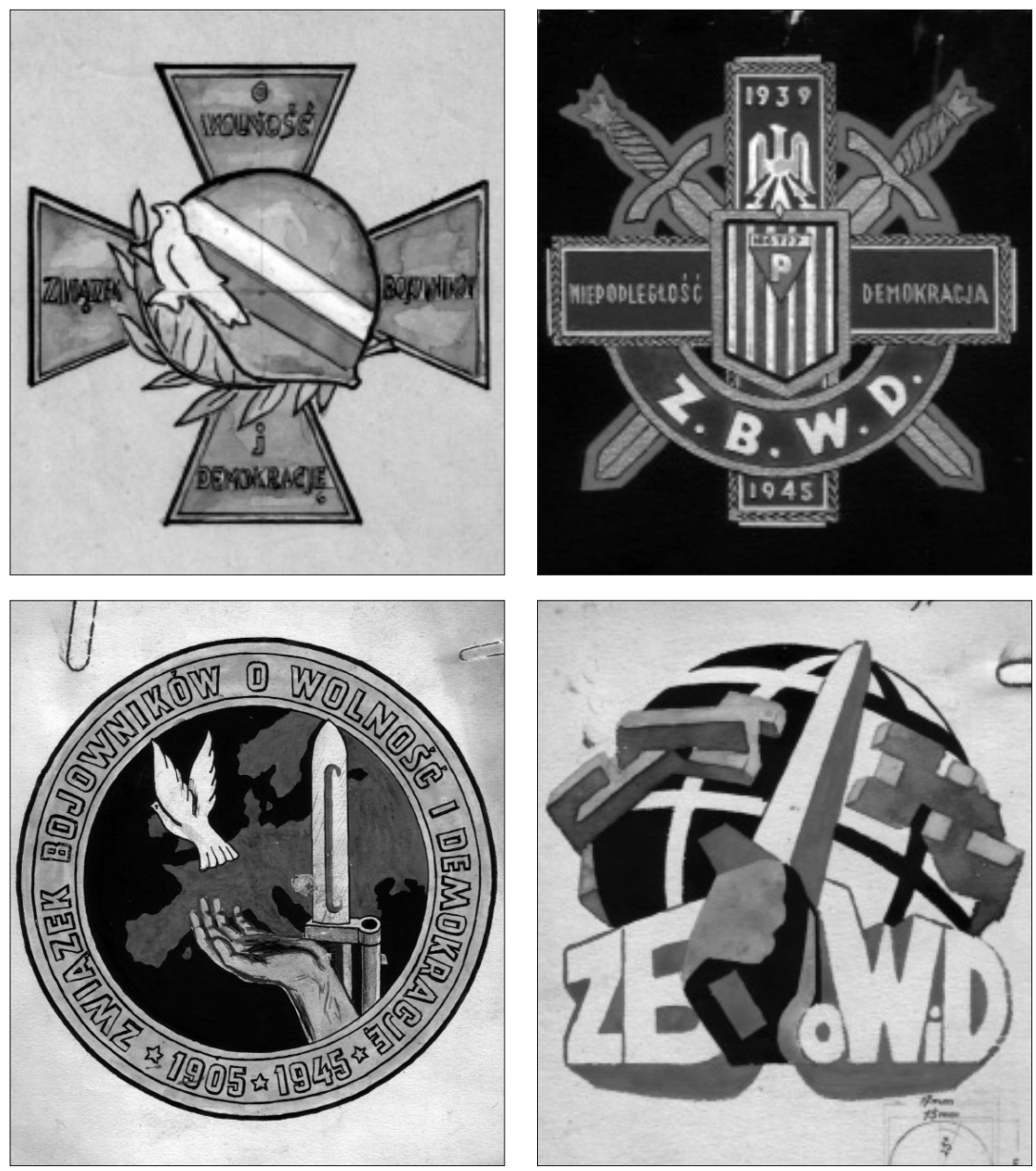

3.5 Conceptualisations of ZBoWiD member's badge submitted to the design contest of 1950 , illustrating the ruling ideas of the time. The explanation under the last one runs:

'The Polish sword (Polish nation) cuts the chains of fascism and capitalism thereby securing world peace. 'AZGZKRPiBWP 3,7.

25 'Protokół z rozszerzonego Plenum ZG ZBoWID', 24 February 1951, AZGZKRPiBWP 3 , 29 , p. 56. 


\section{In the ranks of the national front}

The 'national front' was a concept twinned to the idea of the fight for peace. Its connotations included both force (a front is formed against something, or in defence of something) and social consolidation (a front is formed by units coming together in cooperation). The idea of the front had a chequered history. It started out as a modification of a message sent out by the Communist International, formulated by its secretary general Georgi Dimitrov in the 1930s. ${ }^{26}$ At this time, the 'popular front' replaced the previous guiding slogan of 'class against class', endowing Communist ideology with a drive for integration. The great-power politics of Stalin, in particular the necessity of defending the USSR from the Third Reich, led to the addition of a patriotic accent to the idea of the front. An idea of the front that was complete with a nationalist phraseology was also present in the wartime credo of the Polish Workers' Party in Poland and the Union of Polish Patriots in the Soviet Union. ${ }^{27}$ The first programmatic appeal of the PPR (1943) advocated uniting all forces for the struggle against the occupier, and forming a 'national front for the fight for a free and independent Poland' without 'traitors and capitulators'. ${ }^{28}$ After the war, the idea of the front defined the character and boundaries of the political collective; the PPR used the idea to represent itself as a democratic and all-national party which best expressed the interests of the country, and which had grown from the roots of the Polish working movement and reflected its profoundly patriotic character. ${ }^{29}$ Towards the end of the 1940s, in conjunction with the struggle against nationalist right deviation, the patriotic accent of the concept was tempered and the scope of its meaning was reduced.

The idea of the national front was reprised in February 1951 by Bolesław Bierut at the Sixth Plenum of the PZPR Central Committee. Bierut's aim in employing patriotic rhetoric was to try to legitimize his authority and mobilize Polish society to increase its efforts to fulfil the Six Year Plan. ${ }^{30}$ Bierut, however,

26 See the discussion in: Zaremba, Komunizm, legitymizacja, nacjonalizm, pp. 192-209.

27 The Union of Polish Patriots (Zwiąek Patriotów Polskich; 1943-46) was created and controlled by Stalin, and its political role grew in significance after the Soviet Union broke off relations with the Polish government-in-exile in London. It functioned as a quasi-Polish political representation and was responsible, inter alia, for propaganda concerning the Polish Armed Forces in the East. Krzysztof Tyszka, Nacjonalizm w komunizmie. Ideologia narodowa w Zwiazku Radzieckim i Polsce Ludowej, Warszawa 2004, pp. 131-135; Zaremba, Komunizm, legitymizacja, nacjonalizm, pp. 121-173.

28 'O co walczymy?', in Marcin Malinowski et al. (eds), Polska Partia Robotnicza. Dokumenty Programowe 1942-1948, Warszawa 1984, p. 53; cited in Zaremba, Komunizm, legitymizacja, nacjonalizm, p. 128.

29 Tyszka, pp. 132f.

30 Zaremba, Komunizm, legitymizacja, nacjonalizm, pp. 192-209. 
also emphasized the class dimension of the national front, combining slogans of social (national) integration with messages typical of communist ideology internationalism and revolution. ${ }^{31}$ Thus, the idea of the national front served not only to consolidate support for the government, but also to create an image of an enemy; it played both mobilizing and exclusionary roles.

The pronouncements made by Bolesław Bierut at the plenum of the PZPR Central Committee in February 1951 set all the agendas of the party and state. A speech made by Franciszek Jóźwiak at the plenary meeting of ZBoWiD six days later (at which the necessity of the fight for peace was also expounded) echoed Bierut almost exactly:

Our Party put forward the slogan of the national front fighting against the Hitlerite occupiers, and built up this victorious front around the KRN [Krajowa Rada Narodowa, Homeland National Council $]^{32}$, simultaneously observing that the leader of this front would be the working class - only a national front of that nature could serve its purpose..$^{33}$

The chairman of the veterans' union presented a pantheon of heroes of communist Poland, going back to nineteenth century revolutionaries, and prescribed 'the education of the members in their traditions' ${ }^{34}$ The idea of the national front was therefore connected to the dominant interpretation of the history of Poland, which combined a nationalist pathos with legends of the workers' movement and peasant themes. ${ }^{35}$ It was worked into a narrative that accented social relations, the legitimacy of the ruling authorities and the tasks facing contemporary Polish society. After Jóźwiak's speech, ZBoWiD repeated these ideas frequently, encouraging its members to join the ranks of the national front.

The ideas of the fight for peace and the national front defined the schemes for interpreting the events of the Second World War, as well as the commemorative practices undertaken by ZBoWiD. Above all, they served in the construction of meaning at the principal sites of memory of the Second World War: Nazi camps, battlefields, forests of partisan warfare, and places of urban resistance.

31 Tyszka, p. 138.

32 The Homeland National Council was established at the end of 1943 by communists in Poland as a quasi-parliament in conspiracy; it was one of the communist alternatives to the Polish Underground State (see footnote 6 in Chapter 2).

33 'Przemówienie tow. "Witolda" na posiedzeniu plenarnym ZG ZBoWiD', 24 lutego 1951, AZGKRPiBWP 3, 29, p. 41.

34 Ibid.

35 See for instance: Stanisław Bębenek, Myślenie o przeszłości, Warszawa 1981; Jan Prokop, Wyobraźnia pod nadzorem. Z dziejów literatury i polityki w PRL, Kraków 1994; Andrzej Szpociński, Przemiany obrazy przeszłości Polski. Analiza słuchowisk dla szkót podstawowych 1951-1984, Warszawa 1989; Zaremba, Komunizm, legitymizacja, nacjonalizm, pp. 211-221. 


\section{Sites of Memory and the Myth of Victory}

\section{Concentration camps}

As the propaganda of the Cold War intensified and the manipulation of the image of the ideological enemy (and the atrocities they committed) increasingly became a priority, the former prisoners of Nazi concentration camps and death camps became the emblematic collective heroes for the official historical narrative. Similarly, ZBoWiD's membership in international camp survivors' organizations such as FIAPP, subsequently the International Federation of Resistance Fighters (FIR), became the most important aspect of its ideological activity. Re-narrating the past for use in the conflicts of the present day, these organizations turned concentration camp sites into theatres of the Cold War: they emphasized that the crimes against humanity committed on these territories were the unavoidable consequence of the capitalist system. ${ }^{36}$

FIAPP, as mentioned in the previous chapter, was an organization that commemorated left-wing martyrdom and brought together several different associations from both sides of the Iron Curtain. It was transformed into FIR in 1951, and the main office was moved from Warsaw to Vienna. FIR emphasized the heroism of camp prisoners to an even greater degree than its predecessor; it also welcomed individuals who had not been inmates of a camp, but could provide evidence of their participation in the left-wing armed conspiracy during the war. The membership of ZBoWiD in FIAPP/FIR was a basis for the 'strengthening of bonds of international solidarity with the former participants of the resistance movement and former political prisoners - today's fighters for peace. ${ }^{37}$ The Polish representatives in these organizations (Edward Kowalski, a former prisoner at Auschwitz, and Aleksander Szurek, a fighter in the Dąbrowski brigade during the Spanish Civil War) took part in the most important meetings of ZBoWiD. Za Wolność $i$ Lud had a regular section dedicated to the activities of FIR. The guiding message of FIR was both universalist and internationalist, but national issues were also accented: in 1953, a report on the activity of FIR featured many patriotic formulations, such as 'national independence', 'patriotic consciousness', 'national dignity', and 'the sovereignty of the fatherland'. ${ }^{38}$

The member organizations of FIR, like Polish ZBoWiD or East German VVN, waged a propaganda struggle against colonial wars, West Germany, the ratification

36 Huener, p. 79.

37 'Przemówienie tow. Witolda" na posiedzeniu plenarnym ZG ZBoWiD', 24 February 1951, AZGZKRPiBWP 3, 29, p. 4.

38 'Notatka informacyjna o sesji Biura FIR', Edward Kowalski, 6 June 1953, AZGZKRPiBWP 3,77 , p. 19. 
of the Bonn Treaty (1952) and any other actions that contributed towards the unification of Western Europe. In January 1956, General Secretary of FIR, André Leroy, condemned the European Coal and Steel Community, emphasizing that 'the shadow of Nazism, militarism and pan-Germanism is peeking out from behind the idea of Europe. ${ }^{39}$ The main ideological enemy of FIR was the Free International Federation of Deportees and Internees of the Resistance, which was active in France from 1952. FILDIR drew on Christian values and human rights, defending the idea of the 'free West' and advocating the unification of Germany and also of Europe. One of the speeches printed in the journal Déportation et Liberté, published by FILDIR, bore the title: 'From the Europe of Dachau to the Europe of Strasbourg. ${ }^{40}$

Pieter Lagrou argues that the aggressive propaganda of FIR was also the result of debates in Western Europe about the Gulag, and that they were responding to accusations of crimes against humanity in the USSR. (American funds supported, inter alia, the establishment of an international committee in Brussels, led by David Rousset, which in the years 1949-59 publicized crimes committed in the Soviet camp system). Communists in the West, including former prisoners of Nazi camps (who were affiliated with FIR), denied the existence of the Gulag. Anti- and pro-Soviet groups sparked conflicts within various associations of war victims. ${ }^{41}$ Organizations associated with FIAPP/FIR insisted that the idea of a communist concentration camp was a historical nonsense: only fascism was responsible for the death of millions, and the fascist threat was still real. Edward Kowalski stated at the plenum of the ZBoWiD Central Committee:

The crimes, the atrocities, mass murder, and similar deeds of Hitlerism were not something that resulted from any specific traits of the German people. They are rather the inseparable companion of every imperialism in the epoch of its decay, of its transition into direct aggression, aimed at salvaging the bankrupt capitalist regime at any price, even at the price of murdering millions of people. ${ }^{42}$

The majority of events organized at former concentration camp sites by ZBoWiD were held under the auspices of FIR. Every year, usually in April on the anniversary

39 Lagrou, p. 277.

40 Ibid., p. 279.

41 These conflicts affected organizations that worked with FIR, including: the National Confederation of Political Prisoners (Confédération Nationale des Prisonniers Politiques) in Belgium, the National Union of Former Political Prisoners (Nationale Vereniging der Ex-Politieke Gevangenen) in Holland, and the French National Federation of Deportees, Internees and Patriots (Fédération Nationale des Déportés et Internés Résistants et Patriotes) and the National Federation of Deportees and Internees of the Resistance (Fédération Nationale des Déportés et Interné de la Résistance), ibid., pp. 270f.

42 'Przemówienie Edwarda Kowalskiego na Plenum ZG ZBoWiD', 24 February 1951, AZGZKRPiBWP 3, 29, p. 73. 
of the liberation of Buchenwald, the International Week of the Fight against Fascism and War was organized (also known as the Week of International Solidarity). Foreign delegates visited Poland, and Poles travelled abroad. Commemorative events were held in the GDR - in Buchenwald, Sachsenhausen, Ravensbrück and also in Poland - at Auschwitz and Majdanek. The leadership of FIR also tried to gain control of commemorative events at former camps located in Austria and the Federal Republic of Germany (FRG), specifically Mauthausen and Dachau, which led to arguments with the authorities of those states and also with noncommunist victims' organizations. ${ }^{43}$

Buchenwald and Auschwitz became the most important sites where the socialist bloc demonstrated its power. Buchenwald symbolized the communist resistance movement in the camps: the Socialist Unity Party of Germany (Sozialistische Einheitspartei Deutschlands, SED) cultivated a myth of the liberation of the camp by imprisoned communists, silencing the fact of its liberation by the American military. The first major exhibition at the site was organized in late 1951 by former inmates who had been members of the communist underground. The authors of the exhibition, however, soon became victims of purges within the SED, for example Ernst Busse (a member of the leadership of the German Communist Party, Kommunistische Partei Deutschlands, KPD) who was sent to the Soviet forced labour camp at Vorkuta, where he died. In 1954, to commemorate the tenth anniversary of the death of Ernst Thälmann (leader of the KPD, executed at Buchenwald), a new exhibition was opened that simultaneously accentuated the 'patriotic character' of the German 'anti-fascist resistance movement' and also strived to maintain the image of unity within the oppressed classes during the war. ${ }^{44}$ The organizers of the exhibition requested that ZBoWiD prepare the Polish component. The organization's records give some indication of the nature of this process: a major feature was the top-down 'designation' of martyrs, whereby it was unimportant whether individuals who would be commemorated at the German exhibition had actually died at Buchenwald. At a session of the presidium of the Main Directorate, 'outstanding, deceased Polish representatives of the Resistance Movement [were] chosen, whose names could be inserted into the memorial plaque at the museum in Buchenwald,' and the 'decision [was] made to propose a list to the Secretariat of the PZPR Central Committee, comprising the following names: Nowotko or Finder, Fornalska, Bishop Kozal. ${ }^{45}$ The representatives of

43 Lagrou, p. 275, 276.

44 Volkhard Knigge, 'Instead of a Foreword: the Case History of an Exhibition' in Buchenwald Concentration Camp 1937-1945: A Guide to the Permanent Historical Exhibition, compiled by Harry Stein, Göttingen 2004, p. 9, 10.

45 'Protokół z posiedzenia Prezydium ZG ZBoWiD', 30 July 1954. AZGZKRPiBWP 3, 81, p. 19. Marceli Nowotko (1893-1942) was the first secretary of Polish Workers' Party. 
the presidium, clearly afraid of making a politically incorrect decision, noted that 'the candidature of comrades from the former PPS [Polish Socialist Party] will be confirmed by the Secretariat of the PZPR Central Committee. ${ }^{46}$

The State Museum at Auschwitz (Oświęcim) was another important site for Cold War propaganda. The image of the enemy, as commemorated at this museum, played a particularly significant role. In 1949 the Ministry of Culture ordered the rearrangement of the exhibition established two years earlier. The guidelines for the new display stipulated that a variety of forms of fascism would be included (i.e. not only Hitlerism), and that the fascist tendencies of the USA and West Germany would also be given sufficient attention. The exhibition was ready towards the end of 1950 and featured, for example, photographs of 'released criminals formerly of IG Farben', with inscriptions claiming that the American imperialists had opened factories for the manufacture of Zyklon B. One of the added sections of the exhibition was entitled 'Sources of Genocide', and presented British colonial policy and camps for the Boers in Africa, which were depicted as a prototype of the Nazi concentration camps, as well as black ghettos in the USA, which supposedly were the model for the Jewish ghettos of the Third Reich. Another part of the display bore the title 'The Fight for Peace', and presented the following motifs: the destruction of Hiroshima; concentration camps in Greece, Spain and Yugoslavia; the success of the Six Year Plan; wars in Asia. The theme of the 'liberation struggle' in Korea was particularly prominent. ${ }^{47}$ A ZBoWiD commission, headed by Henryk Matysiak, took part in the creation of the Auschwitz exhibition, suggesting modifications to the content of the exhibit named 'Along the Party Line'. ${ }^{48}$ Like in Buchenwald, the final decisions on the form of the exhibition were taken by the party leadership, including Prime Minister Cyrankiewicz himself. ${ }^{49}$

In 1955, as part of the preparations for the tenth anniversary commemorations of the liberation of Auschwitz, a new permanent exhibition opened (a large part of which is still on display today). The Thaw had a considerable influence on its content, and it was at this time that the most aggressive motifs of Cold War

His death in Warsaw in 1942 from bullet wounds has never been entirely explained. Paweł Finder (1904-44) succeeded him as first secretary; he was captured, tortured by the Gestapo and shot in Warsaw in 1944, together with Małgorzata Fornalska (1902-44), a female communist who at the time was one of the main editors of party propaganda materials. Finally, Michał Kozal (1893-1943) was a Polish Catholic priest killed at Dachau concentration camp.

46 'Protokół z posiedzenia Prezydium ZG ZBoWiD', 28 August 1954, AZGZKRPiBWP 3, 81, p. $39,41$.

47 Huener, pp. 101f. See also Wóycicka, Die Kanalisierung, p. 187.

48 Huener, pp. 99f.

49 Ibid., p. 95. 
propaganda disappeared from the museum (although the revanchism of the FRG remained a key theme), and messages of Polish martyrdom appeared. ${ }^{50}$ The absence of the Holocaust narrative in both displays is well-documented. Jonathan Huener argues that this practice of erasure was the product of the internationalist message of Stalinist discourse, with its anti-Semitism camouflaged under the slogan 'the struggle against cosmopolitanism', and of the dominance of Polish martyrology in later times..$^{51}$ It is important to note, however, that the tendency not to view the Holocaust as a site of memory but to heroize the victims was present in the entire Eastern Bloc in the 1940s and 1950s, as well as in Israel/ Palestine and in several countries of Western Europe. ${ }^{52}$

ZBoWiD replaced the Polish Union of Former Political Prisoners as the principal organizer of commemorative events at the former site of AuschwitzBirkenau. The scenarios of these commemorations and demonstrations were similar to other communist festivities. Foreign guests and local activists paraded against a background of portraits, flags and wreaths. Crowds composed of party representatives, regional and national government figures, social organizations and trade unions participated by listening to long speeches. The first major event organized jointly by ZBoWiD and FIAPP took place in April 1950, and was held in conjunction with a collection of signatures in support of the Stockholm Appeal. Franciszek Jóźwiak emphasized during the process of preparation that 'when the campaign begins on April 11 ... the Union must express its support for the fight for peace through radio broadcasts, press exposure, posters, closed regional rallies and one open rally at Oświęcim. ${ }^{53}$ Over 30,000 people took part in this demonstration, including many foreign delegates. ${ }^{54}$ In Warsaw voivodeship alone, forty organized rallies and commemorative meetings were held to coincide with the Auschwitz event. ${ }^{55}$

Patriot-priests who were members of ZBoWiD also took part in the internationalist demonstrations held at the former camp. Jan Żaryn argues that the convocation of the Main Committee of Priests (and its regional subsidiaries) by $\mathrm{ZBoWiD}$ at the beginning of 1950 was intended by the party authorities as a

50 For a detailed description of the display see ibid., pp. 121-143.

51 Ibid., p. 96.

52 Joanna Wawrzyniak and Zofia Wóycicka, 'Jonathan Huener, Auschwitz, Poland, and the Politics of Commemoration, 1945-1979' [review], Kwartalnik Historii Żydów 2, 218 (2006), p. 273.

53 'Protokół z posiedzenia Plenum Zarządu Głównego', 18 March 1950, AZGZKRPiBWP 3 , 28, p. 3.

54 See the description in: Huener, p. 97.

55 'Protokół z posiedzenia ZO ZBoWiD w Warszawie', 26 April 1950, AAN, ZBoWiD ZG, 1, 380, p. $207 f$. 
way to facilitate the capture of the possessions of the Polish branch of Caritas, and that public orations by priests harmonized with official propaganda against the Vatican and the Catholic Church in Poland, whilst also being anti-German in tone. ${ }^{56}$ Some of these patriot-priests had survived Nazi camps; according to Żaryn, these were the individuals who were supposed to be most easily convinced by the arguments about a new war and German revanchism. ${ }^{57}$ The involvement of the clergy, however, had the consequence that Catholic religious practices became a part of official commemoration. In June 1950, a group of more than forty priests went on a pilgrimage to Auschwitz, where they celebrated mass, read out a letter from Józef Cyrankiewicz and prayed for the well-being of Bolesław Bierut. The press presented this event as a 'spontaneous' demonstration by the priests in support of peace. ${ }^{58}$

ZBoWiD also applied emphasis to its participation in ceremonies commemorating the female victims of medical experiments at the concentration camp at Ravensbrück, whom they invariably described as having been treated as 'guinea pigs' (króliki doświadczalne). Among the various groups who had been victimized in the camps, young women bearing visible physical injuries became the supreme symbol of this crime. In February 1951, representatives of the Main Directorate proposed that such women speak out at meetings of the Women's League in order to 'voice the aim and significance of the fight for peace, based on their own experiences during the occupation.' They appealed primarily for former 'guinea pigs' to speak 'at mass meetings and de-mask the perfidy of the Bonn government. They should deplore [the West German] government's disgraceful treatment of Polish women, who are consigned to living off charity. ${ }^{59}$ The 'charity' in this phrase is a reference to discussions then taking place in the FRG and the UN on the issue of German reparation law, which at this time did not provide for claims from victims of the Third Reich not living in the FRG. In July 1951, as a result of international pressure and political debates, the West German government passed a law stipulating that compensation for war crimes could be offered to citizens of countries with which the FRG had diplomatic relations. This decision excluded the citizens of Poland (against the expectations of Polish victims). It was only on the threshold of the 1950s and 1960s that the

56 Jan Żaryn, 'Księża patrioci - geneza powstawania formacji duchownych i katolickich', Polska 1944/45-1989. Studia i Materiaty 1, 1 (1995), pp. 143f. For more detail on the 'Caritas' affair, see: idem, Kościót a władza w Polsce (1945-1950), Warszawa 1997, pp. 272-295.

57 Żaryn, 'Księża patrioci', p. 139.

58 Huener, pp. 98f.

59 'Protokół z rozszerzonego Plenum ZG ZBoWiD', 24 February 1951, AZGZKRPiBWP 3 , 29 , p. 52. 
West German government made provisions for some financial compensation to the Polish inmates of Ravensbrück. ${ }^{60}$

In January 1952, on the anniversary of the liberation of Auschwitz-Birkenau, ZBoWiD organized an International Meeting of Former Prisoners of Auschwitz, declaring its aim to be: 'the discussion of current political problems concerning the regeneration of the Wehrmacht, the amnestying of former camp torturers and collaborationists, the profanation of the patriotic ideals of the Resistance Movement, and the persecution of former participants of this movement for their patriotic deeds during the occupation. ${ }^{61}$ Delegates from eighteen European countries took part in this event, more than half of whom represented associations and committees of former prisoners that were not affiliated to FIR. The programme was announced in the press and on the radio. In addition to a tour of the former camp and a conference in Warsaw, the programme included meetings of delegates with 'the Polish populace'. ${ }^{62}$

International concentration camp committees were established under the auspices of FIR in 1954, for Auschwitz, Buchenwald, Dachau, Mauthausen, Ravensbrück and Sachsenhausen. Representatives of ZBoWiD participated in the sessions of the International Auschwitz Committee (IAC) from the outset. ${ }^{63}$ ZBoWiD also financed a significant portion of IAC's activity and was involved in its initiatives, including searching for war criminals and making compensation claims to the FRG on behalf of former prisoners. In 1954, ZBoWiD and the IAC jointly organized, inter alia, a conference for doctors that documented the extent of the physical exhaustion of prisoners. The IAC and ZBoWiD also jointly prepared

60 See also Chapter 4. Wanda Jarząbek, 'Władze Polskiej Rzeczpospolitej Ludowej wobec problemu reparacji i odszkodowań od Republiki Federalnej Niemiec 1953-1989', Dzieje Najnowsze 2, 37 (2005), p. 89, 90; Krzysztof Ruchniewicz, Polskie zabiegi o odszkodowania niemieckie w latach 1944/45-1975, Wrocław 2007, pp. 97-132; Dominik Sołtysiak, 'Podstawy prawne i implementacja odszkodowań niemieckich dla polskich ofiar eksperymentów pseudomedycznych w latach 1945-1989', in Witold M. Góralski (ed.), Problem reparacji, odszkodowań $i$ świadczeń $w$ stosunkach polsko-niemieckich 1944-2004, vol. 1: Studia, Warszawa 2004, p. 274, 275.

61 'Rozszerzone tezy sprawozdania Prezydium ZG z działalności ZBoWiD', 11 October 1951 - 15 June 1952, AZGZKRPiBWP 3, 31, p. 95.

62 Ibid.

63 The headquarters of the IAC, like FIR's, were in Vienna. The general secretary of the IAC was Hermann Langbein, a member of the Austrian Communist Party. He left the party in 1956 in protest against the suppression of demonstrations in Hungary that year. He was also known for critical statements concerning the GDR. In 1960 Langbein was expelled from the IAC leadership, and in 1962 the headquarters were moved to Warsaw. See: Lagrou, p. 274, 275; Huener, pp. 147-150; Zofia Wóycicka, 'Zur Internationalität der Gedenkkultur: Die Gedenkstätte Auschwitz-Birkenau im Spannungsfeld zwischen Ost und West 1954-1978', Archiv für Sozialgeschichte 45 (2005), pp. 269-292. 
what was then the largest-scale commemorative event to have taken place at the site of Auschwitz: the tenth-anniversary ceremony of the liberation of the camp. In 1955, thousands of people from all around Poland took part in the event, as well as many foreign delegates. The most important part of the ceremony took place at Birkenau. The main speakers were Marie Normand, head of the French Auschwitz Committee, and Józef Cyrankiewicz, who was always present on such occasions. The Polish speakers by this stage avoided direct accusations linking American imperialism with fascism, but instead underlined the threat emerging from the remilitarization of the FRG. ${ }^{64}$

Much can also be learned about the forms of historical imagination that were dominant in the Cold War period from reading articles about the concentration camps in Za Wolność i Lud. Their defining characteristic was presentism: articles had a didactic tone and offered a simplified interpretation of history. They described a space in which ruthless oppressors persecuted communists, who in turn were martyrs in service of a good cause. However, 'inhuman conditions', 'famine-inducing food rations', 'slave labour', and 'the bestial atrocities of the SS' did not break the revolutionary spirit. Prisoners being led to their deaths sang the Internationale. ${ }^{65}$ 'I have served people and for them I die', Hanka Sawicka is supposed to have proclaimed as she was about to die at Pawiak prison in Warsaw. ${ }^{66}$ According to journalist Krystyna Gust, 'there were communists among the many thousands of people who arrived in Mauthausen in the transports from various countries - and they were the best patriots, resolute in their fight against fascism, brave and devoted fighters for the freedom of peoples.' The members of the international resistance organization 'shared their piece of bread with colleagues, despite their hunger.' They distributed medicine, took on leadership roles among the prisoners, assisted those in need, attended to the sick and those on the verge of death, obtained weapons and taught the prisoners to fight. ${ }^{67}$ The Soviet prisoners of war were noted for their particular heroism and cunning: 'when they realized the difficulty of their situation, they immediately set about devising an escape plan,' wrote Gust. ${ }^{68} \mathrm{Za}$ Wolność $i$ Lud also featured stories of escapes from Auschwitz and the Jewish uprisings at Treblinka and Sobibór, presenting them in terms of revolutionary progress and emphasizing that communists played leading roles. The

64 Huener, p. 116, 117.

65 Tadeusz Kowzan, 'Mój wyrok na was zapadł już dawno. W 10 rocznicę śmierci Juliusza Fucika', Za Wolność i Lud 9 (1953), p. 17.

66 Hanna Jaworska, 'Hanna Sawicka', Za Wolność i Lud 6 (1950), p. 7.

67 Krystyna Gust, 'Międzynarodowy Ruch Oporu w Mauthausen', Za Wolność i Lud 4 (1953), p. $16,17$.

68 Ibid., p. 16, 17. See also: Pierre Daix 'Dzień, jakich w Mauthausen było wiele’, Za Wolność i Lud 5 (1953), p. 11. 
only notable exception to this monolithic narrative of communist endeavour was the recognition of the martyrdom of Polish priests imprisoned at Dachau, whereby care was taken to point out that they were sympathetic to the revolutionary idea; in this way, the image of the progressive patriot-priests was upheld. ${ }^{69}$

Propagandistic manipulation was also achieved by means of applying similar categories to describe both Nazi and non-Nazi concentration camps. The pre-war Polish authorities were presented as having collaborated with the Third Reich, and thus, the prisoners of the Polish Sanacja regime and the inmates of German concentration camps were seen as equivalent. The anonymous author of a text dedicated to the anniversary of the German invasion of Poland wrote:

The future tormentor of Poland, the tormentor of Auschwitz and Majdanek, the head of the Gestapo Himmler was graciously received in Poland. [President Ignacy] Mościcki would go on hunting expeditions with Goering. At Bereza Kartuska, people were beaten in ways tried and tested at Dachau and Buchenwald. [Foreign Minister Józef] Beck waited on Ribbentrop like a butler and prostrated himself in front of Hitler at Berchtesgaden. ${ }^{70}$

Authors publishing in Za Wolność i Lud employed images of workers' rallies in the inter-war period that were violently dispersed, making implicit comparisons with the Second World War. Thus, Monika Warneńska sought to show that at a workers' strike in Kraków in 1923, heavily armed police dealt with women in a brutal and bestial manner, sparing neither the sick nor the pregnant. ${ }^{71}$ Another author compared the forms of torture used against communists to Nazi methods of persecution: 'men had their testicles beaten with truncheons, women were raped, water was poured into people's noses, heels were beaten with truncheons. ${ }^{72}$ Such torture, however, did not quash the rebellion, but rather stiffened the will to resist, which reappeared during the Second World War as anti-Nazi resistance. Za Wolność i Lud underlined repeatedly that communists were the only true defenders of the country. In September 1939, they set out for the front straight from the prisons of the Sanacja regime: 'the commune of political prisoners spontaneously formed four marching columns and set out to do battle in defence of the threatened fatherland; they were ready to join the struggle immediately, despite their tribulations as prison inmates, in order to defeat the Hitlerite enemy.' Marian Buczek, who died at the time, became a

69 E.g. Fr. Stanisław Borowczyk, 'Dachau', Za Wolność i Lud 4 (1953), p. 22.

70 'Z perspektywy czternastu lat', Za Wolność i Lud 10 (1953), pp. 3-5.

71 Monika Warneńska, 'Krakowska wiosna 1936', Za Wolność i Lud 3 (1953), p. 12, 13.

72 Mieczysław Bibrowski, 'Obrońca prawdy. W 10 rocznicę śmierci Teodora Duracza', Za Wolność i Lud 6 (1953), p. 10, 11. 
symbol of this fight: 'a model communist, a patriot fighting for independence, freedom, democracy and socialism. ${ }^{73}$

The revolutionary interpretation of the concentration camps even enabled authors to draw a connection with the nineteenth-century Siberian exile camps (the Gulag, needless to say, was never mentioned); this analogy appeared in several narratives about the lives of Polish and Russian revolutionaries. In his story about the radical activist Jan Hłasko (1855-1881), Józef Kozłowski cited fragments of a poem by Bolesław Czerwieński (1851-1888), in which the exiled hero dies of a heart attack when he sees a transport of prisoners being taken to their execution:

Here they are - comrades in one great cause,

Followers of the same mace.

Though they are in chains, they are free, great though tormented,

Their spirits are forged in the same flames.

They are an eternal threat of revenge to the tyrant,

They are the future which must be won! ${ }^{14}$

The Romantic motifs present in the Siberian stories were also strongly featured in the centenary commemorations of the death of poet Adam Mickiewicz (the 'Year of Mickiewicz', 1955). These ceremonies also became one of the symptoms of the Thaw. ${ }^{75}$ A former prisoner of a sub-camp of Mauthausen, Gusen II, found solace in the reading of the third part of Mickiewicz's dramatic poem Dziady:

Kibitki carriages [which transported prisoners in Tsarist Russia] have merged in my memory with the cattle wagons in which we were hurriedly shuttled from camp to camp as the Red Army approached ... My impressions from reading intertwine with my personal experiences: I read and I compare, read and argue with the great poet. I read and remember, I read and make associations, I read and reproach myself for my lack of humility, because sometimes it seems to me that I suffered more than the characters of the drama. ${ }^{76}$

The camp narratives featured in many issues of Za Wolność $i$ Lud often ended with accusations that the Americans and their allies were continuing the crimes of Nazism. At the time of the trial of Julius and Ethel Rosenberg, the newspaper referred to 'FBI torture houses.' ${ }^{77}$ When the Rosenbergs' execution was carried out, Teofil Witek noted that: 'nightmarish experience from Buchenwald were revived

73 D. Guterman, 'Od Rawicza do Ożarowa', Za Wolność i Lud 9 (1953), p. 6.

74 Józef Kozłowski, ‘Jan Hłasko’, Za Wolność i Lud 4 (1953), p. 20. See also e.g.: Józef Drozdowski, 'Historia carskiego więzienia', Za Wolność i Lud 2 (1953), p. 17; Józef Kozłowski, 'Paweł Toczyski', Za Wolność i Lud 9 (1953), p. 14.

75 Zaremba, Komunizm, legitymizacja, nacjonalizm, pp. 169-171, 224.

76 A. Widera, 'Dziady', Za Wolność i Lud 11(1955), p. 10, 11.

77 Mirosław Azembski, 'Legalne morderstwo', Za Wolność i Lud 1 (1953), p. 16, 17. 
in my memory. ${ }^{97}$ The author of a text about a Greek prison on the island of Jura in the Aegean Sea stated that 'the American imperialists and their Greek monarchistfascist puppets' had set up a concentration camp which was 'the continuation and perfection of the Hitlerite camps such as Dachau. ${ }^{179}$ Likewise, in Yugoslavia, 'an unfortunate country, a land of horror, a land of prisons, concentration camps, Gestapo torture and gallows', the prison island of Goli otok ${ }^{80}$ was identified as a 'symbol of the monstrosity of the Titoist-fascist regime', where convicts were subjected to sophisticated forms of torture. The camp guards were sadists and murderers, and were descendants of 'the Gestapo, Mussolini's political police, all forms of collaborationists, Chetniks and Ustashe'; 'whilst beaten by the guards' Made in USA cudgels, the prisoners move enormous boulders with their bare hands, building military premises on the island.' The author reassured the reader, however, that the prisoners 'do not bow their heads, their belief in a better tomorrow is as hard as steel and stronger than death. ${ }^{81}$

Thus, the martyrology of the camps acquired a supra-historical dimension in the ideology of the Cold War era. The camp was a space where the heroes of the communist cause suffered. It was also a place that represented the worst crimes of fascism in its various embodiments: the Sanacja regime, Nazi Germany and American imperialism, among others. Only the ultimate victory of the forces of peace and social justice, centred in Moscow, could bring an end to people's suffering.

\section{Fields of battle}

The history of camp martyrdom was embellished with a narrative of soldiers' experience, in descriptions of the glorious march and crushing victories of the Red Army as they liberated the Polish territories from German occupation. The Polish Armed Forces in the East were also prominent heroes of this narrative. ${ }^{82}$ The former war correspondent and a political commissar in the Polish Armed Forces and now a prominent communist poet Jerzy Putrament paid tribute to the deceased Stalin in 1953 with the words: 'the prisoner of Auschwitz will not

78 Teofil Witek, 'Te same metody', Za Wolność i Lud 7 (1953), p. 14.

79 Ap. Spilos, 'Jura - grecki obóz śmierci', Za Wolność i Lud 2 (1953), p. 20.

80 An island in the northern Adriatic Sea, today part of Croatia. In 1949 it was transformed into a harsh prison and labour camp for political opponents of Josip Broz Tito's regime in Yugoslavia.

81 Nikola Sandułowicz, 'Goli otok. Wyspa śmierci', Za Wolność i Lud 4 (1953), p. 21.

82 See footnote 13 in Chapter 2. 
forget the One who rescued him from death. The name of Stalin will live in his soul. ${ }^{83}$

Tales about soldiers combined internationalist messages with patriotic ones. They employed motifs drawn from Polish history: the Polish Army, fighting alongside the Red Army, was ascribed a genealogy not only encompassing medieval battles against the Teutonic Knights, wars with Sweden in the early modern era, nineteenth-century popular uprisings, but also culminating in 'proletarian internationalism'. Figures such as Wanda Wasilewska and Alfred Lampe (the founders of the Union of Polish Patriots, the Stalin-sponsored political organization that operated within the Polish Armed Forces in the East) or Karol Świerczewski (a communist, participant of the International Brigades, and Red Army general) were presented as heirs of the emancipatory tradition embodied by individuals such as Stefan Czarniecki, hetman of the Polish armed forces in the seventeenth century, Tadeusz Kościuszko, leader of the 1794 insurrection against the partitions of Poland, Jarosław Dąbrowski, one of the leaders of the January Uprising (1863) and Józef Bem, nineteenth-century Polish and Hungarian independence activist.

These accounts also fused ideological content with narrative devices typical of tales of military heroism. Za Wolność $i$ Lud carried articles that described friendship and loyalty amongst comrades-in-arms, heroic and wise leaders, youthful energy, the will for revenge, and the shared tribulations of military life. The image of the war was black-and-white, the enemy always evil and 'our' hero a beacon of morality with no discernible faults. The senior officers acted as experienced teachers who led by example: they mitigated and avoided rash decisions, and were always the last to leave the field of battle.

These tales heavily accented the theme of blood, a symbol of the brotherhoodin-arms of Polish and Soviet soldiers. Their shared death and common places of burial were the ultimate proof of unity. Similarly to the camp histories, inspiration was taken from nineteenth-century Polish literature and the tradition of messianism. To give a characteristic example, a story based on the motif of a senior officer's death emphasizes Polish-Soviet friendship by employing the Romantic image of the commander's body being interred in the forest, as the soldiers mourn over the grave:

Col. Krasnov lay in his Soviet uniform, which was decorated with numerous medals awarded for his military achievements: at the Battle of Kursk and Orel, by the Dnieper, near Chisinau and Iaşi. The Polish soldiers loved him like a father. Tears glistened in their eyes. And when the dug-out had become completely quiet, when after a couple of hours the mourners had all gone, returning to their battle positions, a young artillerist came to bid farewell to his colonel ... He removed his head covering and knelt by

83 Józef Putrament, 'Dziewiąty marca', Za Wolność i Lud 3 (1953), p. 1. 
the corpse. He held this position for a while, and then got up, kissed the dead man's hand, and unfurled a rolled-up object. It was a red-and-white flag. He must have taken it from the dug-out where the division's political department's equipment was kept. He assiduously, as if putting on a scarf, wrapped the Polish flag around the body. The white-and-red banner engirdled the Soviet uniform dark-scarlet with blood. ${ }^{84}$

The theme of Polish-Soviet friendship and the symbolism of blood also feature in Eugeniusz Kuszko's story Nad Nysq i pod Budziszynem ('Battles of the Nysa [Neisse] River and of Bautzen [a town in eastern Germany]'). In Christ-like fashion, the blood shed by Soviet officers displays reviving properties: it portends the rebirth of the Polish nation. A Red Army officer leading a Polish company dies and becomes an example to his men:

Only the last mine finished him off. It blew off his legs and tore his chest. But the company was already beyond the field of treacherous mines. Next to the leader lay a young Polish soldier, a boy of hardly eighteen years of age, hit by a bullet from a heavy machine gun. His young face looked as if it was smiling at the bright sunlit spring sky. A scarlet streak of blood tinted the soil ... From this blood was born a wonderful life and the eternal fraternity of combat. ${ }^{85}$

The heroic fight of the Polish soldier alongside the Soviet one also had a compensatory character: it atoned for the 'betrayal' of General Władysław Anders, i.e. the fact that he had led some Polish troops out of the USSR to the West. ${ }^{86}$ The Polish Armed Forces in the East underwent their military baptism with honour, thereby eradicating the disgrace of Anders's actions:

At the same time as the Hitlerite hordes approached the walls of impregnable Stalingrad, the band of fascist ringleaders with Anders at its front disgracefully deserted the field of battle, leading Polish soldiers into the wilderness. For the second time after the defeat of September [1939], the Polish bourgeoisie betrayed and sold out the interests of the Polish people. This disgraceful deed of a degenerate fascist, of a traitor to the Polish people in a general's uniform, filled the hearts of the entire Soviet emigration with a feeling of deep pain and shame, as they waged armed battle against the occupier. ${ }^{87}$

ZBoWiD participated in the ceremonies of the Day of the Polish Armed Forces, which took place on the anniversary of the Battle of Lenino (1943) ${ }^{88}$ and also commemorated the anniversaries of other battles in 1945 that symbolized important breakthroughs at the front, such as in Warsaw, at Wał Pomorski, the Battle of the

84 Eugeniusz Kuszko, ‘Żołnierska przyjaźń' Za Wolność i Lud 11 (1953), p. 8, 9.

85 Idem, 'Nad Nysą i pod Budziszynem', Za Wolność i Lud 10 (1953), p. 8, 9.

86 See footnote 13 in Chapter 2.

87 Aleksander Juszkiewicz, 'Związek Patriotów Polskich. W 10 rocznicę pierwszego zjazdu w Moskwie', Za Wolność i Lud 6 (1953), p. 4, 5.

88 See footnote 39 in Chapter 2. 
Oder-Neisse, as well as the conquest of Berlin. The Union's leadership ordered that emphasis be placed on the image of the individual proletarian soldier, thus a former soldier promised to carry out these instructions with 'Bolshevik obstinacy': 'Just as the heroes of Stalingrad sang songs throughout their victorious march, so let us be led by that proletarian song in our union work. ${ }^{89}$ The Red Army, with its advanced technology, brilliant officers 'trained by the Stalinist military school' and soldiers with 'exceptional resourcefulness and orientation', was held to be a source of strength, a model for everyday behaviour, and a guarantor of the security and ultimate victory of the forces of peace. ${ }^{90}$

\section{The forest and the urban resistance}

The image of the camps and the prisons, where the 'progressive portions of humanity' suffered and fought, and of the Red Army rushing to the rescue, was supplemented by descriptions of anti-German resistance. 'Not all the lads let themselves be locked up behind the barbed wire of the concentration camps. Some settled in distant villages, others went into hiding in the forest. Partisan divisions were formed. ${ }^{91}$ Forests and the workers' districts of cities were primary sites of memory cultivated by the propaganda of the period, places where the resistance movement was commemorated. The anti-German conspiracy was predominantly identified with the People's Guard..$^{22}$ Among approximately one hundred accounts of armed resistance in the Second World War (narrated as biographies/hagiographies or as short stories) that appeared in Za Wolność $i$ Lud between 1949 and 1955, more than half described the deeds of the GL/AL or the military dramas of the PPR. Fictionalized accounts of fighting originated primarily in the Lublin, Kielce, or Warsaw regions, i.e. in central parts of Poland that were part of the General Government under German occupation. In reality, most partisan activity was concentrated in the eastern parts of pre-war Poland, but descriptions from these parts were censored due to circumstances such as the wartime struggle against the Ukrainian partisans, the role of the Home Army in the anti-Soviet Operation Tempest, ${ }^{93}$ and the fact that these eastern provinces became part of the USSR after 1945.

Tales about partisans contained, as a rule, a well-defined idea of the enemy: the Germans and their alleged 'collaborators' amongst the leaders of the AK, the

89 'Protokół z rozszerzonego Plenum ZG ZBoWiD', 1 września 1951, AZGZKRPiBWP 3, 30, p. 9.

90 Teofil Witek, ‘Armia Wolności i Pokoju’, Za Wolność i Lud 2 (1953), p. 3.

91 T. Szeląg i Z. Golański, 'Bitwa pod Zaborecznem', Za Wolność i Lud 2 (1953), p. 14.

92 See footnote 20 in Chapter 2.

93 See footnote 17 in Chapter 2. 
government in London, the NSZ and the 'reactionary clergy'. The bravery, devotion and compassion of the communist underground fighters stood in opposition to the cowardice, treachery and lack of honour of the AK. In this picture, the perfidy of the AK commandership was added to by its incompetence, infighting within the middle ranks and the needless deaths of ordinary soldiers. This propaganda presented an ambivalent image of the Peasants' Battalions, which were traditionally linked to the pre-war peasants' party, the Polish People's Party (Polskie Stronnictwo Ludowe, PSL). During the war years, grassroots divisions formed by peasants, often by people hiding in order to avoid deportation to Germany for forced labour, were a real force in the countryside and provided competition to communist agitation. Moreover, the border between affiliation with the Peasants' Battalions and the Home Army was often very blurred. However, authors of articles in $\mathrm{Za}$ Wolność i Lud presented the fighters of the BCh as being torn between the GL/ $\mathrm{AL}$ and $\mathrm{AK}$, thereby depriving them of their own political identity: it was only the GL/AL that defended the village against deportations, forced labour and food requisitions. The anonymous author of a story about 'the birth of popular power in Kielce region' describes smallholder peasants deliberating at a secret meeting in a barn guarded by AL partisans. Their 'long conversations, which ran away into the future and which sought reckoning with both the past and the present', were symbolically contrasted with the background of the black legend of AK and NSZ:

In the cities and towns with a majority-Jewish population, capitalist speculators, degenerate NSZ-ites and the police prey like hyenas on the extermination and tragedy of the Jews; they plunder in league with the Hitlerites and hand people over to the enemy. The village councils, ruled by rich men kowtowing to London, assign the entire burden of the requisitions ordered by the Germans not to the kulaks but to the small- and medium-holders; instead of the sons of the kulaks they send the sons and daughters of poor villagers into forced labour in Germany... AK and NSZ divisions, created in the courtyard and then stationed there, led by Sanacja officers, guard the harvest against the GL and BCh. ${ }^{94}$

Similarly to the discourse of the camps and the soldiers' tales, authors writing about partisans in Za Wolność i Lud employed familiar tropes from nineteenthcentury Polish literature. The forest became a specific and magical setting for the narration of war stories. It was a space of freedom, acting as both shelter and as a theatre of battle. Here, experienced leaders trained young fighters. The partisans repaired their weapons on the forest floor, planned ambushes, treated the wounded, wrote letters to their loved ones, discussed politics, and made friendships. ${ }^{95}$

94 'W Czarnej Hańczy. Narodziny władzy ludowej na Kielecczyźnie', Za Wolność i Lud 6 (1953), p. 8, 9 .

95 See e.g.: Maria Castellatti, 'Bitwa pod Kochanami', Za Wolność i Lud 10 (1953), p. 10, 11; Ryszard Nazarewicz, 'Stefan. Jak walczyła brygada AL im. gen Bema', Za Wolność 
The Soviet partisan movement was the point of reference and the ideal for discussing the activities of the Polish partisans. Za Wolność $i$ Lud reprinted excerpts from Soviet accounts, thereby intertwining the stories of Soviet partisans with the fates of members of the GL. ${ }^{96}$ Narratives about the Polish, Russian and Belarusian underground resistance and partisan movements were complemented with accounts of the left-wing resistance in other countries. ${ }^{97}$ Just as in the stories of the camps and the regular armed forces, the authors of partisan narratives emphasized the positive aspects of the interpersonal bonds formed during the war, drawing particular attention to an internationalist brotherhood. In the divisions of the GL and AL, every individual should be able to find his place, irrespective of his background: 'the Polish Marszałek brothers, the Jew Rubin, and the Soviet partisans "Kolka the Paramedic" and "Shaggy Vasil" all fought together. ${ }^{98}$ It was also claimed that soldiers from the Union of Armed Struggle (Zwiazek Walki Zbrojnej, ZWZ; the predecessor of the AK) and from the Home Army joined the GL partisans, when they realized the righteousness of the cause and the necessity of immediate armed struggle:

Should we let ourselves be picked out one by one? No. Everyone in the division was of this opinion, even 'Luby', who after all had been a member of the ZWZ not long ago, and had nothing to lose from more waiting. The Hitlerites had caught him and were about to execute him when the Guard set him free. He did not return to his old base; he preferred to join the GL. ${ }^{9}$

Such stories made references to workers' holidays, employing presentist fallacies for rhetorical effect. A history written for the May 1 celebration, for example, suggested this holiday was observed by AL partisans in forests during the war. According to the author, 'the partisans were able to step up their military activity thanks to the duties they undertook on May 1.' After a successful skirmish with Germans in the Parczew area, they returned to camp 'with no casualties.' Meanwhile, the Guard helped small- and medium-holder peasants in the fields,

i Lud 8 (1953), pp. 7-9; Teofil Witek, 'Aleksander Skotnicki, Zemsta', Za Wolność i Lud 10 (1953), p. 18; Teofil Witek, 'Stanisław Szybisty, Żołnierz ludu', Za Wolność i Lud 4 (1953), p. 14, 15; Gustaw Alef-Bolkowiak 'Gustaw', 'Jak gwardziści przyjęli wiadomość o powstaniu dywizji im. Kościuszki’, Za Wolność i Lud 10 (1953), p. 5.

96 See also e.g.: W. Andrejew, '1 Maja na małej ziemi', Za Wolność i Lud 5 (1953), p. 16; Zofia Brodzka, 'Stara', Za Wolność i Lud 3 (1953), p. 18, 19.

97 E.g. Jan Reychman, 'Dzieje antyhitlerowskiego ruchu oporu na Węgrzech', Za Wolność i Lud 4 (1953), p. 18, 19; Feliks Róg-Mazurek, 'Lud czechosłowacki w walce przeciwko hitlerowskiemu okupantowi', Za Wolność i Lud 5 (1953), p. 19; Jusuf Alibali, 'Ram Suła', Za Wolność i Lud 7 (1953), p. 19, 20; Leon Witkowski, 'Nigdy więcej grot Ardeatyńskich', Za Wolność i Lud 12 (1953), p. 17.

98 Andrzej Kobyłecki, 'Obóz w Janiszowie uwolniony', Za Wolność i Lud 13 (1951), p. 16.

99 Ibid., p. 8. 
provided military assistance to the partisans of the AK, who thanked them 'with tears in their eyes', and also invited Soviet partisans stationed nearby to their field academy in the forest. ${ }^{100}$

The motif of Polish-Soviet friendship was also employed by Maria Castellati in her short story 'A Common Fight for a Common Cause' (Wspólna walka o wspólna sprawę). Her protagonists Aleksei and Ivan are Russians who have escaped from a PoW camp and joined the AL. Together, 'they tirelessly organized assaults, gave battle, and victoriously faced up to the enemy', and 'on peaceful evenings, when nothing disturbed the troops, they gathered in the forest or in a village they had secured. They organized meetings, conversations, and talks. They spoke about the political situation, the fighting at the front, socialism and the rural economy. ${ }^{101}$

In nearly all accounts, authors emphasized the social support enjoyed by the AL. They described the routes of the local girls who acted as distributors and messengers. Another major theme was the devotion of wives and mothers to the cause of their husbands and sons:

Without this universal support, where would the GL partisan be able to rest his head on a long winter night? Who would feed and nurse him, if not the common Polish peasant-women and female workers? A moment of quiet under the pleasant roofs of their houses was also to be found for the PPR activist being hunted by the Gestapo, the democrat under persecution by reactionaries among his own countrymen, the Soviet PoW who had escaped from a death camp, and the Jew being chased by racists. ${ }^{102}$

Stories about the urban resistance were usually set in the workers' districts of Warsaw. ${ }^{103} \mathrm{Za}$ Wolność $i$ Lud devoted a significant amount of space to stylized biographies of the 'Fourths' (Czwartaki), the participants of a storm division of the AL formed towards the end of 1943. Articles claimed that 'life in the collective nurtured [the soldiers'] most valuable character traits. None of them ever left a comrade in a state of need. ${ }^{104}$ The activity of this group was represented in such a way as to overshadow the legend of the AK and the Warsaw Uprising. The Warsaw Ghetto Uprising, meanwhile, was commemorated selectively. Grand ceremonies co-organized by ZBoWiD marked the tenth anniversary of the Ghetto Uprising in 1953. On this occasion, a Jewish communist, Colonel Gustaw Alef-Bolkowiak (who had spent the war outside of the ghetto), published an article in Za Wolność

100 Anon., '1 Maja w lasach parczewskich', Za Wolność i Lud 5 (1953), p. 6, 7.

101 Maria Castellati, 'Wspólna walka o wspólną sprawę', Za Wolność i Lud 11 (1953), p. 10,11 .

102 Maria Turlejska, 'Bojowniczki o Polskę Ludową', Za Wolność i Lud 3 (1953), p. 11.

103 See e.g.: idem 'Blaszanka', Za Wolność i Lud 12 (1953), p. 8, 9; Teofil Witek, 'Czerwony Sztandar na Kole', Za Wolność i Lud 5 (1953), p. 12, 13.

104 Maria Castellati, 'Czwartacy', Za Wolność i Lud 6 (1953), p. 6, 7. 
$i$ Lud in which he depicted the uprising as a "conscious act of fighting for the freedom and independence of Poland, an act of struggle which had its origins in the Polish Workers' Party, in the first ranks of the People's Guard in the Warsaw Ghetto.' He portrayed the class background of the ghetto, contrasting the general poverty and the Jewish formations of the GL to the 'traitors', i.e. the 'bourgeois' Judenräte, the auxiliary police, and 'fascist-Zionist' organizations. ${ }^{105}$

The messages of stories about partisans usually stretched to the present day: 'and just as the partisans of the Parczew forests with their armed struggle against the occupier tightened the ranks of the national front for the freedom and independence of Poland, so today in our liberated homeland must we strengthen her with redoubled effort and work in the National Front for Struggle and Peace and the Six Year Plan,' wrote Ryszard Nazarewicz, a former member of the AL, party historian and member of ZBoWiD. Former partisans, as well as high officials of the communist party, strived to ascribe a special significance to the anniversaries of partisan skirmishes and battles, attempting to separate them from the ceremonies of the most important celebration day connected to the memory of the war - the International Week of Solidarity (i.e. the commemoration of the liberation of the camps). However, only the next decade would bring significant changes in this respect (see Chapter 5). In the 1950s, no matter how important the legend of the communist partisan movement was for the PPR, it remained in the shadow of the narrative of the concentration camps and soldiers' triumphs.

\section{Behind the Scenes: Organization as Illusion}

\section{Unity and exclusion}

Stories of camp prisoners, soldiers, and partisans were written to bear witness to the unity of the fight against the fascist enemy. Unity also demanded unified symbols - membership cards and fees were a basic requirement of every mass organization in a communist state. ${ }^{106} \mathrm{~A}$ representative of the regional directorate in Warsaw, drawing attention to the low intake of fees, emphasized that 'divisions must understand that the membership fees are not only a source of income, they are also a measure of the political and social consciousness of a member of ZBoWiD

105 Gustaw Alef-Bolkowiak, 'Walczące getto. W 10 rocznicę powstania', Za Wolność i Lud 4 (1953), p. 10, 11.

106 According to historian Marcin Kula, a party member's card (legitymacja) was 'something between a holy relic and an important cult symbol'. See Marcin Kula, Religiopodobny komunizm, Kraków 2003, p. 88. 
as well as of his sense of belonging to the Union. ${ }^{107}$ The official standard was also a sign of the unity of the ranks. According to the instructions of the regional directorate, the standard 'should be carried not only by actual military personnel, but also by civilians, former prisoners, partisans and veterans of 1905. ${ }^{108}$ The standard's design was decided upon at a session of the presidium of the Main Directorate in July 1950. The Union's leaders then ordered that all of the flags of the organizations that preceded ZBoWiD be re-done so as to be identical. ${ }^{109}$

The idea of unity was also connected to a belief in large numbers, as the number of members within an organization was an important indicator of the political system's authority and strength. ZBoWiD was intended as a mass organization, even a giant one. The propaganda documents distributed during the Unification Congress spoke of 400-500,000 individuals brought together under the aegis of ZBoWiD; this figure was repeated in numerous publications about the Union throughout the communist period. ${ }^{110}$ However, these data were far from reliable. The presidium of the Main Directorate admitted as much in 1950: 'the number of members given after the Congress was not correct - they said 400,000, but checks have shown that there are 200,000. ${ }^{\prime 11}$ According to a report of the Supreme Audit Office (Najwyższa Izba Kontroli) in 1951: 'the data concerning the number of members of the Union, given by the Department of Propaganda and Organization, are not reflected in the data of the Personnel Department. ${ }^{112}$

Whatever the actual number of members, it was constantly dwindling during the times of Stalinism: towards the end of 1956, the Main Directorate attempted once again to establish the Union's membership count, and found that there were 50,000 people at most. The idea of unity was, at that time, an idea that excluded others. As seen in the war stories above, the idea of the enemy was the other side of the coin. The 'fight for peace' demanded opposition to sabotage attempts from within the 'forces of peace'. The 'national front' served as a filter: only the chosen could march within its ranks. Traitors of the national-class interest were people who had been active in anti-communist resistance, as well as almost

107 'Protokół z posiedzenia ZO ZBoWiD w Warszawie', 26 July 1950, AAN, ZBoWiD ZG, 1, 380, p. 257 ,

108 'Protokół z posiedzeniu Prezydium ZO ZBoWiD w Lublinie', 23 May 1950, AAN, ZBoWiD ZG, 1, 210, p. 31.

109 'Protokół z posiedzenia Prezydium ZG ZBoWiD', 31 July 1950, AZGZKRPiBWP 3, 67, p. 31 .

110 Mieczysław Góralewski, Tadeusz Kamiński, Organizacje kombatanckie i społecznoobronne w stużbie Ludowej Ojczyzny, 1945-1969, Warszawa 1977, p. 20.

111 'Protokół z posiedzenia Plenum ZG ZBoWiD', 18 March 1950, AZGZKRPiBWP 3, 28, p. 10 .

112 'Wynik kontroli NIK z działalności ZBoWiD', 9 January 1951, AZGZKRPiBWP 8, 5, n.pag. 
anyone of officer rank or higher who had fought in the 1939 defensive war (i.e. the German-Soviet invasion of Poland) or in the Polish Armed Forces in the West or the Home Army. In September 1951, during the Trial of the Generals, ${ }^{113}$ the Main Directorate of ZBoWiD signed a resolution 'on the expulsion of the spy and traitor Jerzy Kirchmayer.' ${ }^{114}$ The deputy chairman Stanisław Kiryluk stated that 'the band of [Stanisław] Tatar and Kirchmayer, recruited from the former officer ranks of the Sanacja [inter-war] armed forces, wanted during the trial to conceal its identity as American and English servants by attempting to construct a superstructure, an ideology that was supposed to guide them in their fight against People's Poland.' Kiryluk embellished his speech, in which he condemned the 'Judas-like mercenaries' and 'venal hirelings of the American genocidal imperialists', with references to the losses of the Warsaw Uprising, which had supposedly begun because of the trickery of the treacherous elites who sought the bloodshed of the Polish people. ${ }^{115}$ It is of note that, at this time, a number of prominent communists were also counted among the traitors of the people supporters, alleged or real, of the 'right nationalist deviation' such as Władysław Gomułka and Marian Spychalski, who were also expelled from ZBoWiD. ${ }^{116} \mathrm{~A}$ number of former fighters of the Dąbrowski brigade of Jewish descent were also imprisoned during anti-Semitic purges of Stalinism in the 1950s.

For middle-ranking officials of the Union, the contradiction between the pressure to increase the numbers of the organization and the expulsion of members with inappropriate biographies caused great difficulty. In the years 1949-52, ZBoWiD was almost permanently carrying out verification measures whose formal criteria, which were wide-ranging and loosely defined, were established at the beginning of 1950. According to the instructions distributed to local verification commissions, eligible members included: veterans of the

113 The Trial of the Generals (proces generałów) was a show trial aimed at cleansing the army of officers who had served in the armed forces of inter-war Poland or in the anti-Nazi resistance during war. The trial was also used as a tool in the internal political struggle among Polish communists. The arrested generals and officers were falsely accused of conspiracy against the Polish state and of collaboration with the British and American intelligence services.

114 'Uchwała Plenum Zarządu Głównego ZBoWiD w sprawie wykluczenia z szeregów związkowych szpiega i zdrajcy narodu Jerzego Kirchmayera', 1 September 1951, AZGZKRPiBWP 3, 30, p. 30. Jerzy Kirchmayer (1895-1959) was an officer of the interwar Polish army, who during the war joined the Home Army, and after the war continued his career in the army as a high-ranking military historian. In the Trial of the Generals he was sentenced to life imprisonment; he was released in 1955.

115 'Zadania ZBoWiD na obecnym etapie wygłoszone na Plenum ZG ZBoWiD', 1 September 1951, ibid., p. 21.

116 Ibid. 
revolutionary struggles of the years 1905-18 and of the Uprisings of Silesia (1919-21) and Wielkopolska (1918-19); former members of the International Brigades in Spain; former prisoners of the Sanacja regime; soldiers who fought for the defence of the country in 1939; partisans and members of the resistance movement who fought against the Nazi occupation; persons kept in Nazi prisons and camps 'for a minimum of three months, for political activity related to one's ethnic or national belonging'; 're-emigrants deported from capitalist countries for anti-fascist activity'; former soldiers of the Polish Armed Forces in the East; and other "soldiers of allied militaries who fought outside the borders of Poland."117 The deciding factor, however, was one's attitude to People's Poland. In January 1950 in Lublin, it was openly admitted that this was the only criterion. ${ }^{118}$

At first, the verification process was hindered by bureaucratic inefficiency - the regulation document had not been delivered from the Main Directorate to the regional chapters, so local activists did not know who was eligible to be a member of the Union or what the verification commissions were supposed to do. ${ }^{119}$ The situation began to improve in the first quarter of 1950. In March of that year, at a plenary session of the Main Directorate, it was emphasized that 'we are removing foreign elements, anti-communist spies, policemen [i.e. members of the Nazi auxiliary police], former guards of Sanacja prisons, speculators, etc. ' ${ }^{120}$ Henryk Matysiak stated, however, that 'purification' was not yet complete, and drew attention to the need for 'scrupulous checks.' 121 The verification commission summoned in Warsaw that year was called the 'cleansing commission [komisja czyszczaca]'. ${ }^{122}$ According to a representative, the commission in Warsaw had the task of 'permanently assessing the morality of members. ${ }^{123}$ In February 1951, the removal of 'wreckers and enemies of the

117 'Instrukcja nr 10 dla komisji weryfikacyjnych', 1 January 1950, AZGZKRPiBWP 11, 9, p. 4, 5. In March 1950, after the establishment of the Main Commission of Patriot Priests within ZBoWiD, all priests (and not only those who had been in the camps) were encouraged to apply for membership in the Union. See: Żaryn, Kościół a władza, p. 296.

118 'Sprawozdanie za styczeń 1950 z działalności referatu organizacyjno-propagandowego Zarządu Okręgu w Lublinie', AAN, ZBoWiD ZG, 1, 210, p. 62

119 'Protokół z posiedzenia Zarządu Okręgu w Warszawie', 19 October 1949, AAN, ZBoWiD ZG, 1, 380, pp. 23f.

120 'Protokół z posiedzenia Plenum ZG ZBoWiD', 18 March 1950, AZGZKRPiBWP 3, 28, p. 5.

121 Ibid., p. 14.

122 'Protokoły okręgowej komisji weryfikacyjnej w Warszawie', n.d., AZGZKRPiBWP 11, 10, p. 23.

123 'Protokół z posiedzenia Zarządu Okręgu w Warszawie', 4 January 1950, AAN, ZBoWiD ZG, 1, 380, p. 123. 
system from our members' ranks' was made a priority in the framework plan outlining the organization's agenda. ${ }^{124}$

It is clear that the verification carried out under ideological auspices led to the gradual thinning of the Union, and that it was especially concerned with the Home Army, the largest armed formation of the anti-Nazi conspiracy. In June 1950, the regional directorate in Lublin explained that 'Radzyń county will not have a lot of members because this area did not have organizations like the $\mathrm{AL}$ or the $\mathrm{BCh}$, there was only the AK, but they were openly hostile to the young socialist democracy.' ${ }^{125}$

Communist propaganda directives are, however, difficult to interpret à la lettre - every so often, overactive representatives of local chapters were tempered, at least rhetorically. In September 1951, during the session of the Main Directorate at which the 'traitor and spy' Jerzy Kirchmayer was expelled from the Union, it was recommended that meetings be held to "explain our relationship to the AK.' ${ }^{126}$ The deputy chairman Wilhelm Garncarczyk then criticized the Union for their weak opposition to the 'internal enemy' and insufficient reaction to 'panicked whisperings and other forms of struggle by the class enemy. ${ }^{127}$ At the same time, regular soldiers of the $\mathrm{AK}$ were praised, in a propaganda tactic that treated them as victims of their superiors. Józef Passini, the secretary of the Main Directorate, emphasized that:

The verification process in our organization is not just a formal process, it is also a matter of vigilance in our ranks. However, it is necessary not to overdo the verification and not to drift into sectarianism ... Our members have passed through three or four rounds of verification and this alienates them from the Union. ${ }^{128}$

Similarly, Stanisław Kiryluk stated that 'we must overcome all sectarian views and sectarian politics. ${ }^{129} \mathrm{~A}$ representative of the regional directorate in Warsaw characterized the relationship between the AK on the one hand, and ZBoWiD and the state on the other:

Resentment is the dominant feeling shared by Union members and former Home Army fighters in Warsaw voivodeship, resulting from the fact that the latter are being dismissed from their jobs because of their former affiliation. It is our duty to inform members at our meetings of the reasons behind such treatment of former AK members. It is well-

124 'Ramowy plan pracy ZBoWiD na rok 1951', AZGZKRPiBWP 3, 29, p. 65

125 'Protokół z posiedzenia Prezydium ZO ZBoWiD w Lublinie,' 7 June 1950, AAN, ZBoWiD ZG, 1, 210, p. 26.

126 'Protokół z rozszerzonego Plenum ZG ZBoWiD', 1 September 1951, AZGZKRPiBWP 3 , 30, p. 24.

127 Ibid., p. 3.

128 Ibid., p. 2.

129 'Zadania ZBoWiD na obecnym etapie wygłoszone na Plenum ZG ZBoWiD', 1 September 1951, ibid., p. 23. 
known that many soldiers of the Home Army joined its ranks purely for the purpose of fighting the occupant, and they were unaware of the vile dealings of its leaders. ${ }^{130}$

However in June 1952, an 'intensification of the fight against destructive elements' and 'constant purification of hostile and demoralized elements [and] economic and political wreckers' were once again ordered during a session of the Main Directorate. ${ }^{131}$ Franciszek Jóźwiak explained, speaking metaphorically: 'when an abscess has grown, you mustn't pierce it, but pick up a good scalpel, do proper surgery, and then the wound will heal and the person will be healthy. ${ }^{132}$ Information concerning the latter stages of verification is lacking. However, it can be assumed that they were overshadowed by a different phenomenon - the intentional liquidation of the regional structures of ZBoWiD.

\section{'We have been unable to plough this fallow field'}

In June 1952, Franciszek Jóźwiak expressed himself using another metaphor: 'In this area, we have not yet been able to plough this fallow field. We have been unable to till the soil exactly and properly and spread the right fertilizer, in other words to instate an ideology in order for noble and beautiful ideas of building socialism in our country to grow. ${ }^{133}$ Behind this image was concealed the idea that the lower echelons of the organization were not carrying out the instructions of the Main Directorate. The order to reach out and gain control over local-level activity - presented as a priority - was met with difficulties characteristic of the times, significantly including a shortage of devoted and suitably trained personnel. Inadequacies in staffing were reported by all organizations, including the communist party, youth association and the armed forces. ${ }^{134}$ Moreover, the lower the profile of an organization (at this time ZBoWiD was among the lesser bodies in Poland), the more difficult it was for them to keep its workers and most faithful activists.

Regional secretaries initially employed on a permanent basis were discovered to be 'not up to ideological standards.' ${ }^{135}$ According to a report of the Main

130 'Protokół z rozszerzonego Plenum Zarządu Głównego ZBoWiD', 1 September 1951, ibid., p. 6.

131 'Referat gen. "Witolda". IV rozszerzone Plenum ZG ZBoWiD', 20 June 1952, AZGZKRPiBWP 3, 31, p. 57.

132 'Protokół z posiedzenia Plenum ZG ZBoWiD', 20 June 1952, ibid., p. 72.

133 Ibid., p. 68.

134 Marek Wierzbicki, Związek Młodzieży Polskiej i jego członkowie, Warszawa 2006, pp. $315 f$.

135 'Sprawozdanie za styczeń 1950 z działalności referatu organizacyjno-propagandowego Zarządu Okręgu w Lublinie’, AAN, ZBoWiD ZG, 1, 210, p. 62. 
Directorate, a senior inspector in Lublin voivodeship was 'expelled from the [party] apparatus for frequent drunkenness. Currently he is not drinking - he is fit to be a regional inspector [for ZBoWiD]. ${ }^{\prime 136}$ The secretary of ZBoWiD's Main Directorate, Józef Passini, proposed a junior secretary of his local party cell for the vacant position of personnel inspector at $\mathrm{ZBoWiD}$, arguing that 'the accusation of semi-literacy laid by deputy chairman Kiryluk is not a barrier to carrying out the responsibilities in that area. ${ }^{137}$ Arrests were another factor that complicated the task of the regional chapters. According to one set of minutes, the revision commission of the regional directorate in Warsaw in 1950 'carried out only two inspections, because some members of the directorate had left and others were in prison. ${ }^{138}$

Another reason for the high turnover of permanent employees was low pay. Officials at various levels drew attention to this problem: for example, the Warsaw directorate explained in 1949 that 'the district directorate will be unable fully to comply with the wide array of tasks set by the Main Directorate, due to scarce personnel and salaries that are, for Warsaw, too low.' ${ }^{139}$ Three years later, Wilhelm Garncarczyk stated whilst explaining the 'elastification of the payment net' (i.e. the lowering of subscription fees) to a government inspection, that he was having difficulties with 'keeping employees in work at this organization.' ${ }^{140}$

The Main Directorate attempted to shift some of the propaganda work to activists. However, it could not find enough volunteers. It tried to mobilize people whom it thought it could rely on - employees of the power structures and party activists. ${ }^{141}$ They were, however, overburdened with duties at other mass organizations. Bernard Fuksiewicz explained this as follows: 'people who are settled in their positions at the Union cannot work productively in several social functions at the same time, just as people cannot work effectively if they have arrived at the Union's leadership with no knowledge of its work. ${ }^{142}$ In Lublin, the chief of the regional directorate drew attention to the fact that many directorate

136 'Sprawozdanie z przeprowadzonej kontroli w ZO Lublin', 11-12 November 1952, AZGZKRPiBWP 3, 76, p. 37.

137 'Protokół z posiedzenia Prezydium ZG ZBoWiD', 28 February 1951, AZGZKRPiBWP 3 , 70, p. 19.

138 'Protokół z zebrania ZO ZBoWiD', 11 November 1950, AAN, ZBoWiD ZG, 1, 4, p. 321.

139 'Protokół z posiedzenia ZO ZBoWiD w Warszawie', 23 November 1949, AAN, ZBoWiD ZG, 1, 380, p. 62.

140 'Sprawozdanie $\mathrm{z}$ inspekcji przeprowadzonej w ZBoWiD przez Starszego Inspektora Prezydium Rady Ministrów 23 maja - 8 czerwca 1952', AZGZKRPiBWP 8, 5, n.pag.

141 'Protokół z posiedzenia Plenum ZG ZBoWID', 18 March 1950, AZGZKRPiBWP 3, 28, p. 10.

142 Ibid., p. 10. 
members were also members of the party, 'which is a mistake because these people have been and are seriously involved in social work in other areas. ${ }^{143}$

To reach its intended audience on a day-to-day basis, mass propaganda requires effective means of locomotion. The Main Directorate of ZBoWiD had at its disposal in 1952 six automobiles, of which four worked, but the employees of regional directorates had to use public transport. According to one report, at the regional level, cars were only lent out for use by patriot-priests. ${ }^{144}$ Employees of the Main Directorate who worked in the field were told by the Union's authorities that they should use 'urban transport channels' and 'the railway network', ${ }^{145}$ which was not a very realistic solution considering the high levels of damage to infrastructure that had resulted from the war. The use of taxis was allowed by the Main Directorate only for special ceremonies in which representatives of party and state and foreign guests took part, for example the 'Auschwitz event', which 'made it necessary to use fast modes of transport. ${ }^{146}$ The ceremony at Auschwitz in 1951 was mentioned frequently in administrative reports - clearly, it gave the organization's accountants many sleepless nights, as activists had claimed significant expenses not foreseen in the budget. Representatives of the regional directorate in Lublin were among those who complained of difficulties in 'reaching the field.' ${ }^{147}$ They drew attention to the fact that 'buses are overcrowded, and hire cars are expensive.' ${ }^{148}$ They floated the idea of buying bicycles for county secretaries, ${ }^{149}$ and complained that they could not get out to local districts because 'they are reachable only by car or by bicycle, which the local chapters do not possess. ${ }^{150}$ The winter conditions and frosts in certain areas made propaganda work completely impossible.

143 'Protokół z posiedzenia ZO ZBoWiD w Lublinie', 3 March 1951, AAN, ZBoWiD ZG, 1, 210, p. 140.

144 'Wyjaśnienie ZG ZBoWiD dla Urzędu Rady Ministrów, Biura Planowania i Finansów', 12 March 1953, AZGZKRPiBWP 8, 5, n.pag.

145 Ibid.

146 'Sprawozdanie z inspekcji przeprowadzonej w ZBoWiD przez Starszego Inspektora Prezydium Rady Ministrów 23 maja - 8 czerwca 1952', AZGZKRPiBWP 8, 5, n.pag.

147 'Protokół z posiedzenia Prezydium ZO ZBoWiD w Lublinie', 6 March 1950, AAN, ZBoWiD ZG, 1, 210.

148 'Protokół z walnego zjazdu powiatowego członków ZBoWiD we Włodawie', 2 April 1950, ibid., p. 49.

149 'Protokół z posiedzeniu Prezydium ZO ZBoWiD w Lublinie', 9 March 1950, ibid., p. 33.

150 'Sprawozdanie za styczeń 1950 z działalności referatu organizacyjno-propagandowego Zarządu Okręgu w Lublinie’, ibid., p. 65. 


\section{The withdrawal of patronage and awards}

'We entered a phase of so-called reorganization of ZBoWiD's work which was understood by all members as a rapidly progressing liquidation of our organization', stated Wilhelm Garncarczyk in 1957, in an overview of the organization's activity in the years 1949-56. ${ }^{151}$ It transpires from sources left by some of the Union's administrative cells and minutes of sessions of the Main Directorate that employee positions and regional structures were gradually phased out. As a result, ZBoWiD became little more than a dummy used for propaganda purposes.

At a meeting in January 1951, the Secretariat of the Political Bureau of the PZPR Central Committee re-analysed the guidelines then in place for the economic plan for the coming year, and before approving the instructions for the acquisition of grain, it:

[d]rew attention to the fact that $\mathrm{ZBoWiD}$ had played a large role in the popularization of the slogans of the fight for peace, but at the current stage, after the establishment of the [Polish] Committee for the Defence of Peace, the responsibilities of the organization had become significantly reduced. The Secretariat recommended to com[rade] Ochab that he reach an agreement with the Main Directorate of ZBoWiD regarding forms of communication and cooperation with the committees of defenders of peace. The secretariat recognized as a target the liquidation of permanent employee positions at ZBoWiD at county level. ${ }^{152}$

A few days later, the presidium of the Main Directorate ordered the 'removal of all of the Union's paid permanent staff at the county level, effective as of 28 February', as well as 'support to all branches of the Union's work at the level of divisions, and interest groups of directorate members and activists carrying out social and voluntary activity. ${ }^{\prime 153}$ The dismissal of permanent staff was labelled as a means of avoiding 'administrative growth' ${ }^{154}$ In this way, the Main Directorate was left with nineteen members of staff (including the caretaker). Further reductions were made in February 1954 at the provincial level. ${ }^{155}$ The available administrative

151 'Wyjaśnienie do protokołu Głównej Komisji Rewizyjnej ZBoWiD z 20 marca 1957 złożone 1 lipca 1957 przez głównego księgowego Piotra Zabłockiego i Członka Rady Naczelnej Wilhelma Garncarczyka', AZGZKRPiBWP 8, 1, n.pag.

152 'Protokół nr 60 posiedzenia Sekretariatu Biura Politycznego i [Sekretariatu] Biura Organizacyjnego', 19 January 1951, in Antoni Dudek, Aleksander Kochański and Krzysztof Persak (eds), Centrum władzy. Protokoty posiedzeń kierownictwa PZPR. Wybór z lat 1949-1970, Warszawa 2000, p. 82.

153 'Protokół z posiedzenia Prezydium ZG ZBoWiD', 27 January 1951, AZGZKRPiBWP 3, 70 , p. 6.

154 'Ramowy plan pracy ZBoWiD na rok 1951', ibid., p. 65.

155 'Protokół z posiedzenia Prezydium ZG ZBoWiD', 17 February 1954, AZGZKRPiBWP 3 , 80 , p. 21. 
data do not tell us how many members of staff were employed by ZBoWiD across the whole country, but even if one assumes that the figure was somewhat larger than the nineteen workers of the Main Directorate, it was still very small. For comparison, in 1954 the Union of Polish Youth (which was also reducing its number of staff) employed over 6,000 people. ${ }^{156}$

At the start of 1951 the Main Directorate formally decided to transfer 'without damages' all of the Union's group and county-level premises to other organizations. ZBoWiD only reserved the right to continue to use these offices free of charge. ${ }^{157}$ This decision undoubtedly had an atomizing effect (although it is difficult to judge whether this effect was intended): veterans no longer had places to meet. The decision also contradicted complaints made by representatives of the Union's leadership to the effect that propaganda was unable to reach 'concrete individuals'; that 'the masses, on whom we rely, are dead'; 158 that the 'field [was] inactive'; ${ }^{159}$ or that 'in many counties, offices [were found to be] closed.' ${ }^{160}$ It showed that these accusations had a ritual quality, that they merely provided cover for the liquidation of the organization.

From 1951, the central offices received increasing numbers of reports from the provinces that described the departure of disillusioned ZBoWiD activists. For instance, a report from Lublin voivodeship stated that 'members are not attending sessions, although they have been notified several times'; and that 'the regional directorate sent a letter to the branch in Puławy, but the letter was returned with a scribble on the back of the envelope that "the Veterans' Union does not exist in Puławy." "161 An inspection in Tomaszów Lubelski showed a 'lack of outreach to members, which has caused a certain degree of forgetting about membership of the Union.' 162 In Łuków, it was reported that 'nobody has conducted Union work for a year ... not even the presidium pays its dues. ${ }^{163}$ In Tomaszów Lubelski, 'the current members of the directorate ... have no wish to hear about working for

156 Wierzbicki, p. 315.

157 'Protokół z posiedzenia Prezydium ZG ZBoWiD', 27 January 1951, AZGZKRPiBWP 3, 70 , p. 6.

158 'Protokół z zebrania Zarządu Okręgu ZBoWiD w Lublinie', 11 November 1950, AAN, ZBoWiD ZG, 1, 4, p. 315.

159 'Protokół zrozszerzonego Plenum Zarządu Głównego', 24February 1951,AZGZKRPiBWP 3,29 , p. 56.

160 'Protokół z rozszerzonego Plenum Zarządu Głównego ZBoWiD', 1 September 1951, AZGZKRPiBWP 3, 30, p. 7.

161 'Protokół z posiedzenia Zarządu Oddziału ZBoWiD w Tomaszowie Lubelskim', 10 August 1951, ibid., p. 41.

162 'Sprawozdanie z pobytu w terenie 31 lipca - 4 sierpnia 1953 w Powiecie Tomaszów', AAN, ZBoWiD ZG, 1, 223, p. 62.

163 'Sprawozdanie z delegacji' 16-18 December 1952, AAN, ZBoWiD ZG, 1, 223, p. 36. 
the Union.' Seven people were expected to attend a meeting called for eighty. ${ }^{164}$ In smaller towns of the area, eleven besieged individuals who at some point had been members of the Union 'refused their membership, on the grounds of being overburdened with social work or on account of old age. ${ }^{165}$ The iconic symbols of the organization were not functioning - fees were not being collected and membership cards were not being distributed. ${ }^{166}$

In 1957, Wilhelm Garncarczyk, in a report already referred to here, wrote:

I can state with a full responsibility that from 1951, and particularly from 1953, the provincial cells of PZPR were almost totally uninterested in the activity of ZBoWiD and provided no support for its work ... There was never any time for talking about ZBoWiD. This attitude of the Party to ZBoWiD finished off our organization. ${ }^{167}$

Garncarczyk's indictments are well confirmed by decisions of the Political Bureau. In August 1951, representatives of the party, who were moved to rectify the neglect of education among conscripts and military families, issued a document that ordered 'enlightenment work among the popular masses.' The aim of this initiative was to present the armed forces as a body 'of workers and peasants, which had developed in the best traditions of fighting for the freedom of the Polish people, as the guardian of our independence and of the achievements of building socialism.' They sought to involve, in addition to party cells: the Union of Polish Youth, trade unions, the League of Friends of Soldiers, the Air Force League, The Navy League, the Women's League, the press, radio, cinematographers, and centres of culture and enlightenment. ${ }^{168}$ The veterans' association receive no mention whatsoever in this long list of organizations that would carry out work related to military themes. The cult of the Polish army, which was developed on the pages of ZBoWiD's journal and through various commemoration ceremonies, did not therefore mean that the Union had actual close ties with the armed forces. Thus, the regional activity of ZBoWiD began to wane in 1952. Several patriot-

164 'Sprawozdanie z delegacji' 16-23 December 1952, ibid., p. 38.

165 'Sprawozdanie z pobytu w kołach Żułkiewice Wysokie [Żółkiewka, Wysokie]', Turobin, 1 April 1953, ibid., p. 25.

166 'Sprawozdanie z działalności ZO ZBoWiD w Lublinie od 1 stycznia do 1 września 1951', ibid., p. 123.

167 'Wyjaśnienie do protokołu Głównej Komisji Rewizyjnej ZBoWiD z 20 marca 1957 złożone 1 lipca 1957 przez głównego księgowego Piotra Zabłockiego i Członka Rady Naczelnej Wilhelma Garncarczyka', AZGZKRPiBWP 8, 1, n.pag.

168 'Instrukcja KC PZPR zatwierdzona przez Sekretariat BP KC PZPR 8 sierpnia $1951 \mathrm{w}$ sprawie zacieśniania więzi między Wojskiem Polskim a masami pracującymi oraz opieki nad poborowymi i rodzinami wojskowymi', in Aleksander Kochański, Krzysztof Persak and Jerzy Poksiński (eds), Kierownictwo PPR i PZPR wobec wojska 1944-1956, Warszawa 2003, p. 284. 
priests also played a role in the liquidation of $\mathrm{ZBoWiD}$, by trying to leave the organization in 1953 and $1954 .{ }^{169}$

Between 1945 and 1948, providing welfare assistance had been a priority for organizations of veterans and former political prisoners. In the early 1950s, alongside the liquidation of its branches, ZBoWiD embarked on a policy of withdrawing this patronage. In March 1950, Wacław Rózga criticized the activity of former associations, underlining that "frequently it was limited to economic or sponsoring activity that remained confined to "one's own backyard", which led to demobilization rather than ideological and political fortification. ${ }^{170}$ At the same time, the accountants of ZBoWiD reported decreased revenues, caused by a ban on conducting economic activity. They reported that they had faced difficulties in funding scholarships and children's holidays, and also that plans were in place for the liquidation of both long- and short-term benefit payments. ${ }^{171}$ Subsequently, ZBoWiD almost entirely withdrew its social support programme. In 1950 and 1951, following government guidelines, the Main Directorate transferred several sanatoria, preventoria, orphanages and care homes to various ministries. In January 1951, it liquidated its welfare department. ${ }^{172}$

From 1951, subsidies from the government comprised the organization's main source of funding (Table 3.1). These subsidies were low and did not cover administrative costs, let alone patronage activity. Limited funds were generated by leasing the Union's real estate holdings, and also from the sale of movable assets (particularly in 1954) - if anything an indicator of the ongoing liquidation of the organization. The proportion of propaganda and administrative expenses (i.e. wages, costs for the upkeep of offices, travel, etc.) increased, whilst that of social welfare expenses steadily decreased (Table 3.2). In 1955 and 1956, after the reduction of staff numbers, the share of propaganda-related (so-called 'socio-political') expenses in the annual budget was as much as 70 percent and 63.5 percent respectively. Meanwhile, social welfare costs from 1951 oscillated between 2 and 5 percent of the budget. These figures demonstrate unambiguously that propaganda was the only function the organization retained.

169 'Protokół z zebrania Wydziału Wykonawczego Głównej Komisji Księży’, 8 January 1954, AIPN 0648/152, p. 158.

170 'Protokół z posiedzenia Plenum Zarządu Głównego', 18 March 1950, AZGZKRPiBWP 3, 28, p. 3.

171 Ibid.

172 'Protokół z posiedzenia Prezydium ZG ZBoWiD', 27 January 1951, AZGZKRPiBWP 3, 70, p. 7. 
Table 3.1 ZBoWiD's income between 1950 and 1956 (thousands of zloty)

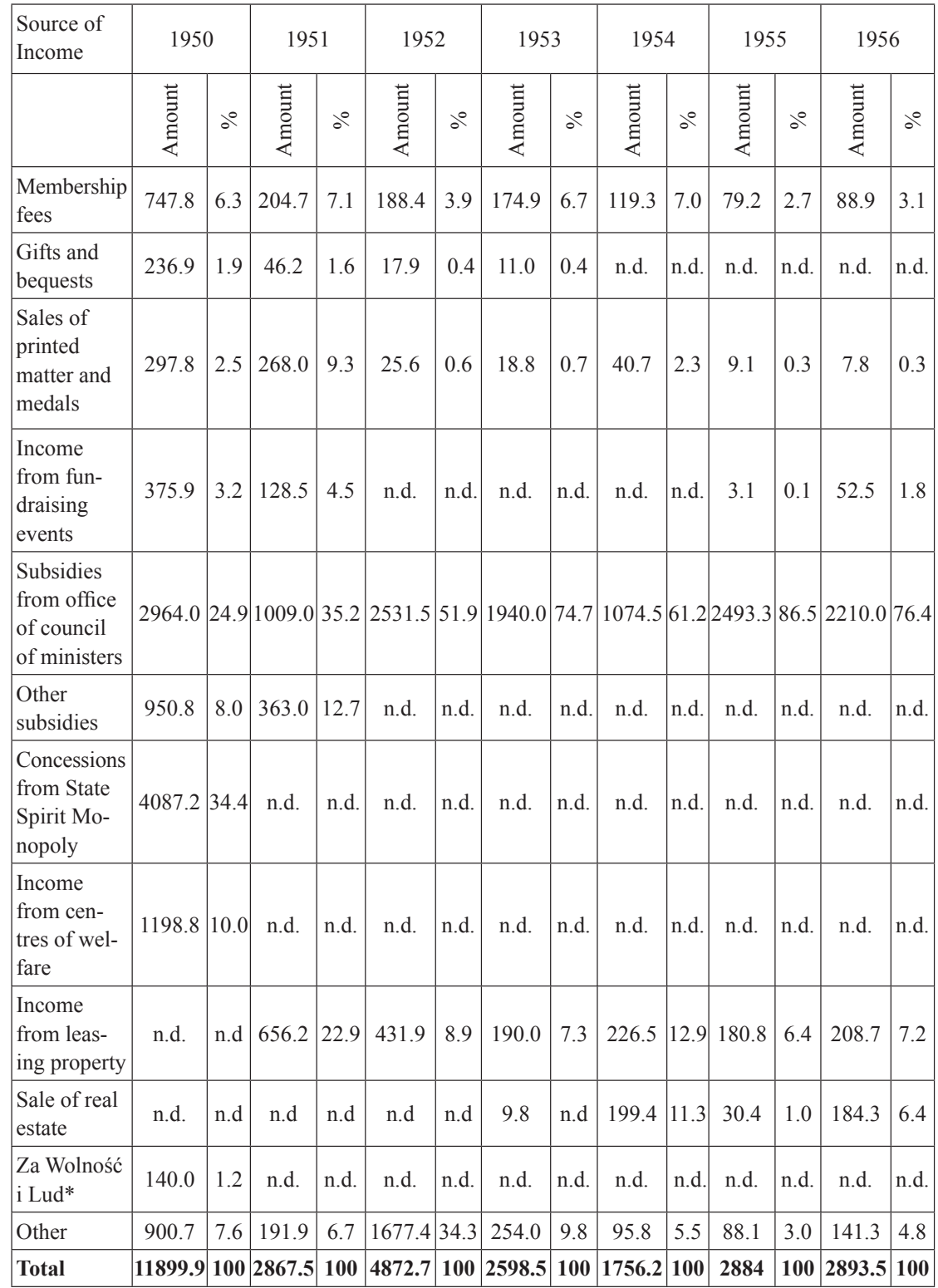

Source: AZGZKRPiBWP 8, 1, n.pag.

* From 1951, Za Wolność i Lud was published by the 'Czytelnik' publishing house. 
Table 3.2 ZBoWiD's expenses between 1950 and 1956 (thousands of ztoty)

\begin{tabular}{|c|c|c|c|c|c|c|c|c|c|c|c|c|c|c|}
\hline \multirow[t]{2}{*}{$\begin{array}{l}\text { Type of } \\
\text { Expense }\end{array}$} & \multicolumn{2}{|c|}{1950} & \multicolumn{2}{|c|}{1951} & \multicolumn{2}{|c|}{1952} & \multicolumn{2}{|c|}{1953} & \multicolumn{2}{|c|}{1954} & \multicolumn{2}{|c|}{1955} & \multicolumn{2}{|c|}{1956} \\
\hline & $\begin{array}{l}\vec{\Xi} \\
\text { 妾 } \\
\text { 定 }\end{array}$ & $0^{\circ}$ & $\begin{array}{l}\text { 䓂 } \\
\text { 主 }\end{array}$ & $a^{0}$ & $\begin{array}{l}\text { 泀 } \\
\text { 妾 }\end{array}$ & $\partial^{\circ}$ & 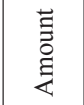 & $a^{\circ}$ & $\begin{array}{l}\text { 䓂 } \\
\text { 妾 }\end{array}$ & $0^{\circ}$ & 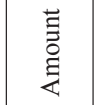 & $0^{\circ}$ & $\begin{array}{l}\text { 㭉 } \\
\text { 主 } \\
\text { }\end{array}$ & $0^{\circ}$ \\
\hline $\begin{array}{l}\text { Adminis- } \\
\text { trative }\end{array}$ & 6969.5 & 47.8 & 3281.7 & 75.2 & 2295.3 & 56.7 & 2110.4 & 69.9 & 1793.0 & 62.2 & 627.1 & 21.8 & 877.5 & 31.8 \\
\hline $\begin{array}{l}\text { Social } \\
\text { welfare }\end{array}$ & 2304.5 & 16.0 & 205.1 & 4.7 & 85.6 & 2.1 & 102.1 & 3.4 & 95.8 & 5.0 & 98.7 & 3.5 & 78.9 & 2.8 \\
\hline $\begin{array}{l}\text { Socio- } \\
\text { political }\end{array}$ & 1339.3 & 9.5 & 532.8 & 12.2 & 1318.4 & 32.6 & 566.5 & 18.7 & 511.6 & 26.6 & 2017.4 & 70.1 & 1771.8 & 63.5 \\
\hline $\begin{array}{l}\text { Expenses } \\
\text { of welfare } \\
\text { centres }\end{array}$ & 3606.2 & 25.1 & n.d. & n.d. & n.d. & n.d. & n.d. & n.d. & n.d. & n.d. & n.d. & n.d. & n.d. & n.d. \\
\hline $\begin{array}{l}\text { Liquida- } \\
\text { tion of } \\
\text { unions by } \\
\text { ZBoWiD }\end{array}$ & 65.8 & 0.5 & 291.4 & 6.7 & 153.4 & 3.8 & 219.8 & 7.3 & 119.0 & 6.2 & 133.6 & 4.6 & 60.0 & 1.9 \\
\hline Other & 188.0 & 1.3 & 48.7 & 1.2 & 196.3 & 4.8 & 21.1 & \begin{tabular}{|l|}
0.9 \\
\end{tabular} & n.d. & n.d. & n.d. & n.d. & n.d. & n.d. \\
\hline Total & 14373.3 & \begin{tabular}{|l|}
300 \\
\end{tabular} & 4359.7 & 100 & 4047 & 100 & 3019 & 100 & 1919.8 & \begin{tabular}{|l|l|}
300 \\
\end{tabular} & 2876.8 & 100 & 2788.2 & 100 \\
\hline
\end{tabular}

Source: AZGZKRPiBWP 8, 1, n.pag.

The discourse surrounding welfare became both politicized and subordinated to the rhetoric of work. The Main Directorate placed a special emphasis on the 'productivization' of those under its patronage. It recommended the organization of 'training workshops for the disabled'; the 'rehabilitation in sanatoria of members of the Union, so that they can work'; 'taking all those who are eligible under our care, including widows and the disabled, into [a programme of] productivization'; ${ }^{173}$ and 'above all, helping widows and orphans by placing children in orphanages. Widows can be provided with employment.' ${ }^{174}$

ZBoWiD offered direct, full-time support only to the victims of medical experiments at Ravensbrück. In October 1949, the Main Directorate registered its readiness to offer "help for the treatment of "guinea pigs." 175 It should be noted,

173 'Protokół z posiedzenia Prezydium ZG ZBoWiD', 15 December 1949, AZGZKRPiBWP 3, 69, p. 24.

174 'Protokół z posiedzenia Plenum Zarządu Głównego', 18 March 1950, AZGZKRPiBWP 3, 28, p. 12.

175 'Protokół z posiedzenia Prezydium ZG ZBoWiD', 25 October 1949, AZGZKRPiBWP 3, 69 , p. 10. 
however, that this did not extend to proposing any sort of group autonomy within the organization to these women: an order that 'a separate section of "Ravensbrück Women" should not be created, even if they want it' was recorded five months later. ${ }^{176}$ Support for other people took the form of pressuring state institutions for official recognition that help was required. For example, the presidium of the Main Directorate decided to petition Józef Cyrankiewicz on behalf of former concentration camp inmates who had lost one or more limbs, for the right to be covered by disability legislation and have the costs of prosthesis covered by the state. ${ }^{177}$ The Union did have some limited funds for providing emergency or temporary benefits, but these monies were mostly spent on propaganda activity (as were the permanent funds for victims of Ravensbrück). According to a financial report, over nine months in 1952, the Main Directorate 'provided benefits amounting to a total of 23,466 złoty. The majority of these funds were paid to members of the resistance movement from capitalist countries, where former resistance fighters are currently persecuted. ${ }^{178}$ Local-level records show that increasing numbers of requests for medicine, prosthetic limbs, footwear and clothes were refused.

The situation improved somewhat for a portion of veterans in June 1954, when a universal pension scheme was launched, and in August 1954, when a decree was passed that provided for people who were disabled as a result of service in the military. ${ }^{179}$ These regulations did not, however, cover everyone - only people who had been employed for five years, not including prison terms and time spent in the underground movement, and professional military personnel were eligible and the payments were low. According to data from the Central Statistical Office (Gtówny Urząd Statystyczny, GUS), the average disability allowance payment in 1955 was 79 złoty per month. For this amount, it was possible to buy a kilogram of ordinary sausage (26zł), half a litre of vodka (34zł), a kilogram of herring (18zł) and a third of a kilogram of bread (1zł). The price of a male overcoat (658zt) was more than eight times the monthly allowance. At the same time, the average pension allowance paid according to the universal pension scheme was 335 złoty per month.

176 'Protokół z posiedzenia Prezydium ZG ZBoWiD', 21 February 1950, AZGZKRPiBWP 3 , 69, p. 48.

177 'Protokół z posiedzenia Prezydium ZG ZBoWiD', 10 October 1951, AZGZKRPiBWP 3, 72, p. 19

178 'Wyjaśnienie ZG ZBoWiD dla Urzędu Rady Ministrów, Biura Planowania i Finansów', 12 March 1953, AZGZKRPiBWP 8, 5, n.pag.

179 'Dekret z 25 czerwca 1954 o powszechnym zaopatrzeniu emerytalnym pracowników i ich rodzin', Dz.U. nr 30, poz. 116. 
The Union's withdrawal of patronage initiatives harmed the essential basis of the organization's legitimacy. After the Unification Congress at a rally in Krasnystaw, a certain Antoni Szuba from Lopiennik 'opined that there are many combatants, but they have no social support and the powers-that-be don't remember them.' ${ }^{180}$ According to the minutes of the presidium of the Main Directorate, d[eputy] chairman Szewczyk took the following position on the issue of the revision of benefit payments - 'it is difficult to carry out political work when widows are being deprived of their allowances. ${ }^{181}$ In Tomaszów Lubelski, 'lack of consideration on the matter of allowances for those widowed and orphaned by the war' was given as one of the reasons behind a dwindling interest in ZBoWiD. ${ }^{182}$ Local directorates also justified their rejection of new membership applications by pointing to the absence of benefits. A party activist in Lublin voivodeship explained on behalf of veterans: 'the Union provides no assistance, but they have too many dues to pay, as it often happens that one person belongs to six organizations. ${ }^{183}$

'Do decorated military personnel continue to deserve honours?' - a representative of the regional directorate of $\mathrm{ZBoWiD}$ in Lublin suggested raising such a question with the party Provincial Committee in the spring of $1950 .{ }^{184}$ This was a topical issue, as awards for service during the Second World War were reluctantly handed out at this time. ZBoWiD documents from the second half of 1950 suggest a conflict with the office of President Bolesław Bierut over rejected applications for decoration. The matter was referred by Gen. Franciszek Księżarczyk, who did not agree with the decision: 'the Honours Commission considers the materials it submits v[ery] carefully. In the documents sent to the party, the majority of candidates proposed for honours were people with no grounds for objection, including some candidates for posthumous decoration.' ${ }^{185}$ Stanisław Kiryluk, who took up the cause, stated that Bolesław Bierut had informed him in private conversation that 'the giving of honours for the occupation period should be considered completed; now, applications should be sent for former combatants who distinguished themselves in the rebuilding and building of People's

180 'Protokoły z zebrań wyborczych w powiatach w woj. lubelskim [1949]', AAN, ZBoWiD ZG, 1, 2, p. 355 .

181 'Protokół z posiedzenia Prezydium ZG ZBoWiD', 17 July 1950, AZGZKRPiBWP 3, 67, p. 38.

182 'Sprawozdanie z działalności Zarządu Oddziału ZBoWiD w Tomaszowie Lubelskim', 1 September 1951 - 1 August 1952, AAN, ZBoWiD ZG, 1, 223, p. 58.

183 'Sprawozdanie z pobytu w kołach Żułkiewka Wysokie', Turobin, 1 April 1953, ibid., p. 25.

184 'Protokół z posiedzenia Plenum ZO ZBoWID w Lublinie', 28 March 1950, AAN, ZBoWiD ZG, 1, 210, p. 47.

185 'Protokół z posiedzenia Prezydium ZG ZBoWiD', 31 August 1950, AZGZKRPiBWP 3, 67, p. 28. 
Poland. ${ }^{186}$ According to the presidium of the Main Directorate of ZBoWiD: 'the non-consideration of the applications sent to the Main Honours Commission ... was the result of the presentation of individuals who are currently in prison or are not deserving of military honours for political reasons. ${ }^{187}$ The fact that awards for service during the war were curtailed, when juxtaposed with the disbandment of the local structures of the Union and the cuts in social welfare, was a sure sign of the liquidation of ZBoWiD as a veterans' association.

The logic of the myth of victory, which sought to mobilize the masses into participating in rituals and constructing a narrative of military glory that would serve the current politics, had profound effects on the practical running of ZBoWiD. Showing that the threat from fascism was still present, and that the ranks of veterans should unite for a future (and this time, final) victory, laid the foundations for the withdrawal of the Union's traditional functions as a patronage organization. Veterans and victims of war were deprived of military decorations and social welfare, and local premises where they could meet and remember the war were taken away. Therefore, the myth of victory over fascism simultaneously entailed the depreciation of wartime experience, and also excluded individuals and groups by labelling as traitors those who were (considered to be) opponents of the new regime. By declaring 'unity', it atomized veterans' groups.

The question arises whether ZBoWiD was a 'transmission belt' of power to society, as mass organizations in the Soviet bloc were then construed. It appears that the only transmission was of intensive propaganda and the rituals of mass ceremony. However, the Union spurned other vehicles for 'reaching the masses', as a result of which a fundamental contradiction arose between its declared aims and actual practice. The organization's leadership sent out opposite signals: on the one hand, it declared full mobilization, and on the other, it was withdrawing social support, emptying organizational premises, and dismissing the staff who could carry out the aims of mobilization. In practical terms, therefore, ZBoWiD was not a transmission belt, but a propagandistic illusion.

The next chapters will show that the process of de-Stalinization brought changes not only in ideological formulae, but also in relations with the social sphere, which had been ignored in the Stalinist era. The new legitimacy formula that emerged after 1956, the myth of the unity of the resistance movement, rang in harmony with organizations of a clientelistic type which carried out patronage

186 'Protokół z posiedzenia Prezydium ZG ZBoWiD', 3 September 1950, AZGZKRPiBWP 3 , 66, p. 4.

187 Ibid. 
functions. Parts of the myth of victory over fascism did not, however, disappear entirely, and still played a significant role in the middle of the 1960s during the twentieth anniversary commemorations of the end of the Second World War and the one-thousand year anniversary of the Polish state. Former fighters of the international brigades in the Spanish Civil War, the Dąbrowski fighters, remained 'living symbols' who would lead the celebrations on anniversaries of the start of the Spanish war in 1956 and 1966, as did demobilized soldier-settlers from the formerly German territories (the former symbolized the beginning of the fight against fascism, the latter its victorious outcome).

The theme of the 'fight for peace' would also return in the first half of the 1960s, although in a less aggressive form than in the Stalinist era. Za Wolność $i$ Lud took up themes related to liberation movements in French and British colonies, nuclear disarmament and banning the production of weapons of mass destruction (the declaration of the Rapacki plan ${ }^{188}$ provided a reason to discuss halting nuclear arms production throughout Europe at the $\mathrm{ZBoWiD}$ forum). Interpretive clichés from the Korean War returned during the Vietnam offensive and the 1967 war in the Middle East.

The German question retained a dominant place in the ideological activity of the Union-ZBoWiD organized many events and demonstrations that condemned the Federal Republic of Germany and emphasized the 'bond of friendship' with the GDR. FIR remained a strategic partner of ZBoWiD and had an especially important role in ideological issues concerning international politics. Representatives of the Union continued to participate in the work of FIR and travelled to conferences and seminars organized by the latter. The fourth congress of FIR took place in Warsaw in 1962 and approved an appeal to global public opinion in which the need was declared for the unity of all people of good will in supporting universal nuclear disarmament and peaceful co-existence. The International Auschwitz Committee was another institution that remained an important partner for ZBoWiD. Jointly with the IAC, ZBoWiD played an active part in the Auschwitz trials held in Frankfurt and was deeply involved in seeking evidence against the perpetrators. Nonetheless, despite the continued relevance of such themes, it was two derivative myths - the unity of the resistance and the innocence of the victims - that played the most significant role after 1956.

188 A project for gradual disarmament and the creation of a nuclear-free zone, proposed at the UN in 1957 by Adam Rapacki, the foreign minister of Poland. 


\section{Chapter 4 \\ The Myth of Unity (1956-59)}

\section{Memory Unbound}

The Thaw in Poland has traditionally been described in terms of conflicts between opposing cliques in the corridors of power. Some authors examine the ethnic and ideological tensions between Polish Communists; others argue that the political changes were a 'ritual drama' played out for the consumption of the public. ${ }^{1}$ These approaches are countered by historian Paweł Machcewicz, who paints a picture of a mass social movement that entered the public stage and contested the existing political order. ${ }^{2}$ Despite appearances, however, these contrasting approaches do not contradict each other, but rather show the same phenomenon from different angles: they illuminate history either from the top-down or the bottom-up. ${ }^{3}$ This chapter attempts to understand the changes that resulted from a collision of interests between the state authorities and the grassroots elements of Polish society. It presents the rejection by the veterans' and former prisoners' groups of the ideological formulae of the Stalinist years, and the reaction of the authorities in creating a new legitimizing narrative: the myth of the unity of the resistance movement, which utilized parts of the myth of victory over fascism but also rearranged the hierarchy of wartime narratives. Unlike its Stalinist predecessor, the new myth was inclusivist, but in stipulating the unity of diverse groups and interests, it also falsified the history of the war.

De-Stalinization arrived in Poland quickly, thanks to a rapidly unfolding chain of events: the USSR's change in direction under Nikita Khrushchev, whose 'Secret Speech' about the crimes of Stalinism (February 1956) was widely distributed in Warsaw; the death of Bolesław Bierut (March 1956); the outbreak of the workers' protests in Poznań (June 1956); and finally, the election of Władysław Gomułka as the First Secretary of the Party (October 1956) at a moment when the uprising in

1 Witold Jedlicki, Klub Krzywego Koła, Warszawa 1963; Jadwiga Staniszkis, Poland's SelfLimiting Revolution, Princeton 1984, pp. $278 \mathrm{f}$.

2 Paweł Machcewicz, Polski rok 1956, Warszawa 1993.

3 See discussion by Paweł Machcewicz, 'Zmiana czy kontynuacja? Polska przed i po Październiku '56?' in Dariusz Stola and Marcin Zaremba (eds), PRL. Trwanie i zmiana, Warszawa 2003, pp. 120-131. 
Budapest was being observed with bated breath and trepidation. The process led to the opening up of the public realm, where the contest for the control of the memory of the Second World War was played out under new rules, requiring something other than the raw violence of the preceding era. State control disappeared, as did, to a large extent, self-censorship. What was at stake in this game for the new party apparatus was the legitimacy of the state authorities. The 'traditions' of the Stalinist era were discarded, and a re-evaluation of the system of rule was required for the regime to maintain its grip on power. Change had to be profound enough to satisfy the society, but also shallow enough not to result in the collapse of the political system which had drawn its authenticity from the outcome of the Second World War.

The year 1956 has been called a time of the 'explosion of collective memory' in Poland, and for good reason. ${ }^{4}$ Already in the early spring of that year, during discussions of Khrushchev's speech organized by the PZPR, the taboos of the Stalinist narrative of history were being challenged at the highest party level, and the post-war model of Polish-Soviet relations was being questioned. The participants of these discussions raised issues such as the annexation of Poland's pre-war eastern provinces on 17 September 1939 by the Soviet Union (referred to as an 'attack' and a 'stab in the back'), the deportations of Polish citizens and their slave labour in the Gulag, the Katyn massacre (1940), ${ }^{5}$ the Warsaw Uprising (1944), the mistreatment of soldiers of the Home Army after the end of the war, and the show trials against its leaders. ${ }^{6}$ Further political developments encouraged the resurfacing of even more hitherto suppressed histories.

An amnesty was declared in April 1956 for approximately 10,000 political prisoners (some had already been freed from prison in 1955), ${ }^{7}$ and many others had their sentences commuted. ${ }^{8}$ The amnesty was an act of pardon and did not automatically entail the repeal of the sentences. The process of

4 Machcewicz, Polski rok, p. 26.

5 The so-called Katyn massacre (zbrodnia katyńska) has been the most vividly remembered crime of the Soviet NKVD against Poles. In the early spring 1940 over 20,000 Polish army and police officers, as well as other male representatives of Polish intelligentsia were murdered in Katyn Forest (near Smolensk) and elsewhere in Soviet Union. Until 1990, the USSR maintained that the victims had been murdered by the Nazis in 1941. See for instance, Alexander Etkind, Rory Finnin et al., Remembering Katyn, Cambridge 2012.

6 Machcewicz, Polski rok, pp. 25f.

7 Zbysław Rykowski and Wiesław Władyka, Polska próba. Październik '56, Kraków 1989, p. 143 .

8 At the same time, some individuals remained in prison, especially people who had been charged with espionage. The best-known case is that of Adam Boryczka (1913-88), an emissary of the émigré authorities, who was sentenced to life imprisonment in 1954; he was freed only in 1967. 
rehabilitating well-known individuals, both from the Home Army and the ranks of communists, was started. The rehabilitations were announced in the press. Transports carrying repatriated Poles from the Soviet Union started to arrive in 1955. Under Gomułka, the government began to treat the repatriations as an important device in the strengthening of their legitimacy. ${ }^{9}$ In March 1957, a bilateral agreement on this issue was signed with the Soviet Union. Altogether, in the years 1955-59, over 240,000 individuals returned to Poland, including political prisoners. ${ }^{10}$

A resolution of the Seventh Plenum of the PZPR Central Committee (18-28 February 1956) pledged changes in the party's attitude towards former soldiers of the Home Army and the Polish Armed Forces in the West. ${ }^{11}$ The plenum also revealed existing conflicts within the circles of the former partisans of the People's Army. Mieczysław Moczar, the communist partisan leader in Łódź, Kielce and Lublin regions during the war, chief of the secret police in Łódź in the 1940s, later in political disgrace, now became Deputy Minister for Interior Affairs. He attacked the Department of the History of the Party over what he saw as their under-valuing of the efforts of the communist partisan movement; he described the party historians as 'burned out', and accused them of a lack of interest in the wartime history of the Polish Workers' Party and in the commemoration of sites where the Nazis had murdered villagers and burned down whole settlements in retaliation to partisan actions: 'you are interested in these villages as much as I am interested in last year's snow. ${ }^{12}$ Another former AL member, General Janusz Zarzycki, who had been removed from his position in the military during the Stalinist period for so-called right-nationalist deviation, called upon the chairman of ZBoWiD Franciszek Jóźwiak to describe the role he had played as a member of the Political Bureau in 'a pointless procedure which broke people and belittled our historical heritage. ${ }^{, 13}$

Censorship abated. Newspaper articles that approached previously suppressed themes became sensations, such as 'Towards a Reconciliation with the Home Army' by Jerzy Ambroziewicz, Walery Namiotkiewicz and Jan Olszewski ('Na spotkanie ludziom z AK', Po prostu, 11 March 1956) and Jerzy Piórkowski's 'We of the Home Army' ('My z AK', Nowa Kultura, 1 April 1956). Quarrels about all-Polish infighting between nationalist and communist groups were

9 Zaremba, Komunizm, legitymizacja, nacjonalizm, p. 241.

10 On repatriation from the Soviet Union see: Małgorzata Ruchniewicz, Repatriacja ludności polskiej z ZSRR w latach 1955-59, Warszawa 2000.

11 Zaremba, p. 238.

12 Lesiakowski, Moczar, p. 186.

13 Ibid., p. 187. 
revived. ${ }^{14}$ Numerous historiographical works and memoirs were also published. ${ }^{15}$ Many war-related anniversaries that had hitherto been suppressed were more or less officially commemorated, including the twelfth anniversary of the Warsaw Uprising. ${ }^{16}$ These articles sparked a heated debate in the press about the wartime conspiracy, which extended into the following year.

At party gatherings and workplace meetings, themes were discussed that had previously been unsafe even within the most intimate and trusted circles, and political topics were openly debated in cafés, private homes, churches, and cemeteries. Major Kamiński, the author of one of many reports of the Ministry of Internal Affairs concerning this situation, observed with some anxiety that 'a whole mass' of meetings, private consultations and 'tea gatherings' had taken place:

If we add to this the huge number of various congresses and meetings arranged in conjunction with anniversaries considered to be symbolic for former AK members, the pretext for the gatherings, the unveiling of signs, etc., there can be no doubt that these meetings are creating the ideal conditions for the reestablishment of contacts [between former combatants of marginalized groups] and re-consolidation [of their organizations]. ${ }^{17}$

In this manner, the debates of the Polish Thaw actively attacked the myth of victory over fascism, which had been built on friendship with the USSR. According to the unofficial narrative which entered the scene, wartime Soviet repressions were presented as comparable to Nazi crimes, and members of the anti-communist conspiracy who had fought Soviet domination were put forward as candidates for the status of national heroes.

\section{Changes}

ZBoWiD had stagnated since 1953, and the first changes occurred in late 1955. The Main Directorate convoked meetings in several counties. The formal aim of

14 E.g. Stefan Kozicki, 'Partyzancka prawda', Nowa Kultura 43 (1957); Aleksander Skarżyński, 'Linia, której zamazywać nie wolno', Polityka 14 (1957); Wojciech Sulewski, 'Narodowe Siły Zbrojne', Polityka 13 (1957).

15 E.g. Adam Borkiewicz, Powstanie warszawskie 1944. Zarys działań natury wojskowej, Warszawa 1957; Jerzy Kirchmayer, Powstanie warszawskie, Warszawa 1959; Jan Rzepecki, Wspomnienia i przyczynki historyczne, Warszawa 1956.

16 For more detail on the commemoration of the uprising and the role of the state in choreographing these ceremonies, see: Sawicki, pp. 103-116.

17 'Ocena działalności niektórych wrogich elementów b[yłej] AK-WiN w ZBoWiD-zie, Warszawa, 26 września 1957. Z-ca Naczelnika Wydz. I Dep III MSW, mjr Kamiński’, AIPN MSW II 3854, p. 23. 
these sessions was to elect new local representations, whereas the actual purpose was to gauge public opinion and to mobilize veterans for participation in the National Front. After the county meetings, preparations were begun for regional meetings. The organizing process lasted until spring $1956,{ }^{18}$ and coincided with the nationwide social upheaval that resulted from Khrushchev's 'Secret Speech' and the death of Bolesław Bierut. Speakers at these congresses, still expressing themselves in the party newspeak, complained about the neglectful attitude of the party and administrative authorities, the confiscation of the Union's property, and the complete absence of social support for those in need.

In May, chairman Franciszek Jóźwiak offered something of a self-criticism, underlining the superficiality of activity to date, which had concentrated primarily on the international communist movement: 'it is good,' he argued, 'that our work in FIR is advancing principally in the areas of gaining influence and developing activity in the countries of Western Europe. However, this must not cause a situation whereby our own [Resistance] Movement is pushed into the shadows and becomes of secondary importance. ${ }^{19}$ Developments snow-balled from that point on. Observers from ZBoWiD travelled to a session of the World Federation of Former Combatants (Fédération Mondiale des Anciens Combattants, FMAC) in Brussels. They even considered applying for membership of this international association, which united the former soldiers of regular armies in capitalist countries. ${ }^{20} \mathrm{ZBoWiD}$ took part in the commemoration of the Warsaw Uprising and dedicated an issue of Za Wolność $i$ Lud to the event. The Union commissioned a tidying up of the neglected Powązki military cemetery and a public collection of funds for a monument to the heroes of Warsaw. The presidium of the Main Directorate decided to publish an article by Jan Rzepecki, the former head of the anti-communist $\mathrm{WiN}^{21}$, which appeared two days before the Eighth Plenum of the PZPR Central Committee. In the article, Rzepecki weighed up the tasks facing

18 Henryk Matysiak, 'W przededniu zjazdów okręgowych ZBoWiD', Za Wolność i Lud 2 (1956), p. 20, 21.

19 'Protokół z posiedzenia Prezydium ZG ZBoWiD', 12 May 1956, AZGZKRPiBWP 3, 85, p. 86 .

20 Ibid., p. 87. No cooperation was agreed at this time because of 'fundamental differences in political conceptions'. Nonetheless, discussions about FMAC continued to be held regularly. After the Third Congress of ZBoWiD a working group was commissioned that looked to established relations with member associations of FMAC. At the beginning of 1967, the then-Secretary General of FMAC, Norman Acton, visited Warsaw. Likewise, a delegation from ZBoWiD took part in an international conference organized by FMAC in London on questions of social legislation for former soldiers, resistance fighters and prisoners. From that time, ZBoWiD maintained regular contact with FMAC.

21 See footnote 3 in Chapter 2. 
the veterans' organization in the altered social reality. ${ }^{22}$ As soon as Władysław Gomułka was elected First Secretary of the PZPR at the Eighth Plenum, a delegation appeared at the Central Committee with a petition addressed to the new leader to broaden the scope of ZBoWiD's activities.

However, it was the gathering of the ZBoWiD Supreme Council (19-20 December 1956) that led to significant shifts in the running of the organization. More than a hundred individuals took part in the event, including many who had travelled from the regions. More than a dozen of the organization's activists, uninvited and deprived of their mandates, arrived at their own expense from Gdańsk, Kraków, Lublin and Wrocław. Also present were former AK and AL soldiers who had been released from prison.

The session was chaired by Prime Minister Józef Cyrankiewicz. A report on the activity of the Main Directorate in the years 1949-56 was read by Wilhelm Garncarczyk in the absence of Franciszek Jóźwiak (who had been removed from the Political Bureau). The report caused subsequent speakers to react angrily, and on the second day the Council accepted the resignation of the incumbent leadership. General Janusz Zarzycki, a left-leaning architect from an assimilated Jewish background who was a member of the communist movement during the war, became the new chairman of ZBoWiD. Since the beginning of the Thaw, he had belonged to the reform-minded wing of the PZPR. At the time he was one of the negotiators of the conditions for the removal of Soviet troops from Poland, and he embarked on a highly successful career in the political apparatus of the armed forces. His manner was later described by another supporter of social change, General Tadeusz Pióro:

People in the armed forces called him 'the princeling' [ksiażatko]. Alongside the virtues that qualified him to fill the highest positions of state, he had an abrupt, not to say arrogant, way of treating those he didn't admire, and this irked even the workers most devoted to him. He did not conceal his disregard for matters that may be trivial, but are treated by military personnel with gravity; he remained above all a politician, and did not commit to the rigours of service, which were too restrictive for his unruly nature. He had a habit of wearing a red silk scarf under his military coat, and colourful socks under his green striped trousers. ${ }^{23}$

The presidium of the new Main Directorate was elected on 21 December 1956. The new deputy chairmen were: Kazimierz Banach, a former chief of staff of the Central Command of the Peasants' Battalions; Adam Kuryłowicz, an official of the Central Council of the Trade Unions, formerly a senior figure in the

22 Jan Rzepecki, 'Kombatanci', Za Wolność i Lud 10 (1956), p. 4, 5, 17 and [Franciszek Księżarczyk], 'O sprawach ZBoWiD-u', ibid. p. 6, 7.

23 Tadeusz Pióro, Armia ze skaza. W Wojsku Polskim 1945-1968 (wspomnienia i refleksje), Warszawa 1994, p. 265, 266. 
PPS, prisoner at Auschwitz, and in the years 1948-54 a member of the PZPR Central Committee; and Franciszek Księżarczyk, leader of a Polish brigade in the Spanish civil war and member of the military staff of the AL, but discredited during the Stalinist period. Księżarczyk resigned in March 1957 after taking up a political position in the armed forces. ${ }^{24}$ Another proposed candidate was the aforementioned Jan Rzepecki, ${ }^{25}$ who, however, refused to participate in any official leadership capacity in ZBoWiD. The problem of there not being a single representative from the AK in the presidium of the Main Directorate was raised several times at plenary sessions of the Directorate, but this issue was not resolved until the organization's Second Congress in 1959. The council also founded a new organizational unit within the structure of ZBoWiD: the Secretariat of the Main Directorate, which was to deal with the majority of everyday administrative tasks. Kazimierz Rusinek, undersecretary of state at the Ministry of Culture and Art (and left-wing journalist, activist of the PPS and PZPR, during the war a prisoner at Prenzlau PoW camp and concentration camp inmate at Stutthof and Mauthausen) became its head. Henryk Matysiak became the secretary for political affairs; he was the only member of the new leadership with a substantial history of involvement in ZBoWiD.

The session of the Supreme Council gave rise to a series of meetings of the central authorities of ZBoWiD. The plenary sessions of the Main Directorate gained a special significance, as it was here that the opinions of various memory groups were voiced. Besides those who made up the presidium, active participants of these meetings included: the writer Tadeusz Hołuj, prisoner at Auschwitz and other Nazi camps in 1942-45, who emerged as a major advocate for the circles of former prisoners; Jerzy Kirchmayer, mentioned above, highranking military officer before the war and co-mastermind of the Home Army's Operation Tempest, sentenced to life-imprisonment during the Stalinist years; Mieczysław Moczar, who acted as an expert on issues related to the partisan movement; Władysław Zdunek, a partisan of the AL from Lublin region; Jerzy Ziętek, who spoke in the name of the fighters of the Silesian Uprisings; Edward Kowalski, who presented on the activities of FIR; and Maria Jaszczukowa, a former prisoner of Auschwitz-Birkenau and Ravensbrück and then-activist of the Women's League, who participated ex officio and promoted the expansion of the role of women and greater understanding of youth problems. Local-level activists were also invited to these meetings - as a result, the sessions became a forum for the discussion of opinions and ideas about the ongoing functioning

24 'Protokół z posiedzenia Prezydium ZG ZBoWiD', 14 March 1957, AZGZKRPiBWP 3, 87, p. 10.

25 'Protokół z posiedzenia Plenum ZG ZBoWiD', 21 March 1956, AZGZKRPiBWP 3, 31, p. 86 . 
of the organization. It was here that conflicts erupted between diverse groups representing various forms of memory, including disagreements concerning the very need for a monopolistic veterans' union, the organization's ideological formulae, and the question of which categories of people could be classified as former combatants. Reports from the provinces also showed that, from the point of view of the new leadership, the mass influx of members posed a serious difficulty for the resolution of these problems.

\section{'They gather almost every day and muck-rake in the past'}

It was an irony of the time that an organization founded during the era of Stalinization was restored from the bottom-up at the time of de-Stalinization. The Main Directorate of ZBoWiD did not gain control over the increased activity of the ranks until the autumn of 1957. Its employees were unable to ascertain how many members the reactivated union now had. According to Henryk Matysiak, 'tens of thousands of people' had joined the organization, yet there was no 'concrete ideological base at the everyday level. In this situation, they gather almost every day and muck-rake in the past, starting with [the histories of] the AK and AL. ${ }^{26}$ Kazimierz Banach spoke to the plenary gathering of the Main Directorate in March 1957 about a 'great influx' of people to the Union: 'these matters are not being regulated at the central and regional levels, and as a result, they are escaping our grasp. ${ }^{27}$ Jan Szaniawski, chairman of the regional directorate in Warsaw, added that 'the Main Directorate is unable to keep up with the development of the movement of our organization. ${ }^{28} \mathrm{~A}$ few weeks later he acknowledged that he would be afraid to convoke a congress because of the liveliness of the ranks. ${ }^{29}$ Sylwester Newiak, the regional secretary in Katowice, admitted in November 1956 that his domain had become 'infected with all kinds of newly established sections and sub-sections. ${ }^{30}$

At all levels of the organization where meetings were held, ZBoWiD was criticized for the façade-like nature of its activity so far. Ignacy Narbutt, a former

26 'Stenogram z posiedzenia Plenum ZG ZBoWiD', 27 May 1957, AZGZKRPiBWP 3, 36, p. 22.

27 'Protokół z posiedzenia Plenum ZG ZBoWiD', 1-2 March 1957, AZGZKRPiBWP 3, 33, p. 9.

28 Ibid., p. 12.

29 'Stenogram z Krajowej Narady ZBoWiD', 29 March 1957, AZGZKRPiBWP 3, 102, p. 131.

30 'Stenogram z posiedzenia Plenum ZG ZBoWiD', 12 November 1957, AZGZKRPiBWP 3, 34 , p. 36. 
partisan of the People's Army recently released from a Stalinist prison, said: 'there was no reaction to the harm done to our own colleagues. ${ }^{31}$ Holuj argued that: 'it is worth cooperating with organizations abroad, and now it is possible because Poland is fashionable. But we need to take into the Union people who will get things done, rather than just sign declarations about defending peace. ${ }^{32}$ Criticism even touched upon the PZPR. A ZBoWiD official from Gdańsk named Wasilewski demanded less party involvement: 'members of the Party who used to wear different caps are now wearing Phrygian caps and trying by various tiresome methods to halt the work of carving out a new direction. ${ }^{33}$

Settling accounts with the legacy of Stalinism was an important concern. Many speakers demanded the release of prisoners and immediate rehabilitation of individuals who had received court sentences. It was believed that the condemnation of Stalinist repressions would enable the retrieval of lost group identities: 'besides national treasures, besides personal effects, we demand the return of the flags under which we marched for so long. ${ }^{34}$ The argument was also put forward that the persecutions of the first half of the 1950s united the Home Army and the People's Army, groups that had been hostile to each other during the war. Both Jan Mazurkiewicz from AK and Mieczysław Moczar from AL argued this point; they would become two prominent figures in the formulation of the ideology of national communism in the $1960 \mathrm{~s}$, as the next chapter will show. ${ }^{35}$

ZBoWiD's neglect of sites of memory was another source of contention for the participants of the meetings. They drew attention to uncommemorated sites of atrocities, battlefields and places of burial, and an insufficient number of monuments and museums. The huge commemorative events of the Stalinist era had not been accompanied by regular maintenance of these sites. Adam Kuryłowicz said:

I have visited [the camp] recently and can say that at this moment I would be ashamed to take anyone to visit Brzezinka [Birkenau], the gas chambers, which have been levelled to the ground. That is how our most sacred symbols of memory are preserved! This place should be better kept than a church, so that people can come and see where millions of people died. ${ }^{36}$

31 Ibid., p. 136.

32 Ibid.

33 'Stenogram z Krajowej Narady ZBoWiD', 29 March 1957, AZGZKRPiBWP 3, 102, p. 93.

34 Ibid., p. 109.

35 Ibid., p. 99.

36 'Stenogram z posiedzenia Plenum ZG ZBoWiD', 27 May 1957, AZGZKRPiBWP 3, 36, p. $28,29$. 
Hołuj also voiced his disapproval at the state of the museum: 'I have to say that what is happening at Oświęcim is worse than terrible. The situation is so bad that I don't even want to talk about it. It often happens that foreign delegates wrap the bones of our heroes [scattered on the ground] in paper.' Another person commented on the neglect of the concentration camp at Płaszów: 'there is no trace of the camp other than skulls and bones piled up here and there. ${ }^{37}$ Representatives from Gdańsk repeatedly demanded the improvement of conditions and better commemoration at Stutthof concentration camp.

Demands of a material nature, however, were the most common. The social issues that were raised can be divided into a number of groups, but they all concerned poverty in the country. First, a decline in state investment and reductions in heavy industry and administration had led to increased unemployment (officially unacknowledged). Former prisoners and people who were disabled as a result of the war had significant difficulty finding and holding down work. As a result, they petitioned for the introduction of policies that would give them priority in employment procedures, as well as protect them from being laid off without consultation with $\mathrm{ZBoWiD}$. Veterans and former prisoners also expected to receive help in their efforts to establish craft cooperatives and service and trade points.

The second important issue was the introduction of changes to inadequate social welfare legislation. A 1954 pensions and benefits law provided only for former inmates of concentration camps who had worked for at least five years either before or after their internment. ${ }^{38}$ Examples of war victims who were unable to maintain even a minimal level of subsistence were brought up frequently at the meetings. Moreover, private farmers and artisans were not covered by the state healthcare system. They therefore demanded that membership in ZBoWiD grant the right to receive free medical treatment. They also requested easier access to specialist treatment and sanatoria, subsidies for imported medicines and the establishment of retirement homes designated exclusively for war veterans. Closely related to the absence or shortage of welfare measures was the fact that almost all of the veterans' groups supported a return to the policy of awarding military honours for wartime service, which had been all but halted during the Stalinist years; they thereby aimed at increasing the number of so-called 'bread medals', i.e. honours that entitled the holder to enhanced state support. ${ }^{39}$ Home Army representatives also proposed the verification of officer ranks and military

37 'Stenogram z Krajowej Narady ZBoWiD', 29 March 1957, AZGZKRPiBWP 3, 102, p. 76.

38 'Stenogram z posiedzenia Rady Naczelnej ZBoWiD', 21 January 1959, AZGZKRPiBWP 3,17 , p. 16 .

39 Two sets of military honours entitled holders to a 25 percent supplement in addition to their regular pensions: the Order Virtuti Militari (five classes) and the Order of the Cross of 
honours awarded during the German occupation. This was at least partly a question of prestige, but the potential re-adjustment of pension payments was also a factor.

Third, there were various regional demands. For example, the military settlers in the west of the country expected that a 1946 decree of the Ministry of the Defence concerning tax breaks for people purchasing land or real estate in this region would be expanded. Activists from the areas of Silesia and Kaszuby also reported that difficulties had been experienced by Poles: many examples were given of individuals who had been forced to join the Wehrmacht. At the same time, benefits paid to former German soldiers were a source of local Polish discontent (according to international agreements, all former members of the military were legally entitled to certain benefits, regardless of nationality). It was argued that benefits were being paid to former soldiers of the Wehrmacht, but not to their victims..$^{40}$

Finally, the fourth category of issues included various minor grievances and demands, such as discounts on urban transport and priority queuing for all members of ZBoWiD. There were also appeals for ad hoc intervention, most frequently from people experiencing problems with accommodation. All of these matters required that complex solutions be found to the social demands of memory groups by appropriate laws and reforms.

\section{Against the monopoly of memory}

Attempts to define the organizational structure of ZBoWiD comprised an important dimension of the discussions of 1956-57. Despite appearances, this was not a technical question, but a fundamental issue that concerned problems of post-war identity and determined the forms of collective life and the hierarchy of influence and power. The territorial structure of ZBoWiD to date had allowed the Main Directorate to maintain control over the provinces, and had contributed to the fracturing of group bonds formed during the war. People who had fought together or were inmates of the same camp had found themselves in different circles scattered around the country. However, after the convocation of the Supreme Council in December 1956, several memory groups demanded if not independence, then wide-ranging autonomy by means of transition to a federative structure.

Grunwald (three classes). ZBoWiD also made applications on behalf of its members for other state medals that would guarantee additional privileges. Cf. footnote 30 in Chapter 2.

40 'Stenogram z posiedzenia Plenum ZG ZBoWiD', 27 May 1957, AZGZKRPiBWP 3, 36, p. 88 . 
Former prisoners of Nazi concentration camps were a vocal group. Their union had been a wealthy organization and had lost a great deal by joining ZBoWiD. This group applied pressure to solve specific issues which it felt ZBoWiD had not adequately dealt with in the past, such as reparations from the FRG and specialist medical treatment. During the Thaw, representatives of this collective believed they could rely on the support of Prime Minister Józef Cyrankiewicz and successfully demand the return of property of PZbWP. Tadeusz Hołuj advocated for these interests within the Main Directorate. He proposed that ZBoWiD adopt a federal structure, with two main branches: partisans and prisoners. ${ }^{41}$

Not surprisingly, Home Army members comprised another memory group that campaigned for autonomy. The attitudes of former senior officers of the AK concerning ZBoWiD were not uniform. Some officers did not trust the changes that were taking place and preferred to remain on the sidelines. Other officers, however, decided to participate actively in ZBoWiD. These included military personnel who had reached conditional compromises with the authorities in the post-war period, such as the aforementioned Jerzy Kirchmayer, Jan Mazurkiewicz and Zygmunt Netzer. Many others, however, maintained an ambivalent attitude. They would agree to cooperate with the Union if they could be convinced that it actually represented the interests of Home Army soldiers and guaranteed a certain degree of autonomy. ${ }^{42}$

An important example of the Home Army's involvement in ZBoWiD was a group strategy proposed by Jan Mazurkiewicz. After his release from prison in 1956, Mazurkiewicz immediately restarted the assistive activities in which he had been involved in the $1940 \mathrm{~s} .{ }^{43}$ A functionary of the Ministry of Internal Affairs wrote a report about Mazurkiewicz's activities, in which he noted that: 'he is making efforts in many different rehabilitation cases for the AK, frequently appearing as a witness ... letters are being sent to him from practically all over the country, thanking him for his help and advice. ${ }^{34}$ Of course, not everyone was grateful. Groups of 'the unbreakable', i.e. the hardcore faithful to the Home Army's cause, both in Poland and in émigré circles, did not hesitate to remind Mazurkiewicz about his unsuccessful attempts to compromise with the authorities after the war. However, for many people, especially of lower military rank, Mazurkiewicz was

41 'Stenogram z posiedzenia Rady Naczelnej ZBoWiD', 19-20 December 1956, AZGZKRPiBWP 3, 16, p. 86, 88.

42 'Ocena działalności niektórych wrogich elementów b[yłej] AK-WiN w ZBoWiD-zie, Warszawa, 26 września 1957. Z-ca Naczelnika Wydz. I Dep III MSW, mjr Kamiński’, AIPN MSW II 3854.

43 See Chapter 2.

44 'Notatka służbowa dot[ycząca] Mazurkiewicz Jan, 8 stycznia 1957. Sporządził K. Pawłowicz, St. Oficer Operac. Wydz. I Dep. III’, AIPN 0330/217, 2, p. 141. 
an important figure: the café in Warsaw run by him and his wife became a meeting place for many individuals with a connection to the Home Army, including people seeking material support or accommodation and those who wanted to bury their relatives in a military cemetery. Mazurkiewicz encouraged them to join ZBoWiD, believing that it was the only institution capable of representing the interests of the $\mathrm{AK}^{45}$

At the same time, many communists felt a grave sense of uncertainty. The Department of Propaganda and Agitation of the PZPR Central Committee took note of 'the withdrawal of leftist elements from activity in ZBoWiD', and observed that in some areas 'the forces of the PPR and AL are outside the Union. ${ }^{46}$ In September 1957, Major Kamiński from the Ministry of Internal Affairs observed:

a frontal attack on the old directorates of ZBoWiD and attempts to remove members under the pretext that they were Stalinists, people compromised by their violation of law, etc. Spontaneously organized meetings turned into rallies (especially in the regions), at which openly hostile remarks aimed at socialist power, members of the Party, the AL, etc., became mass phenomena... Neither the regional authorities of ZBoWiD, nor Party representatives were able to counter it in any effective way. Meanwhile, the leadership circles of the GL and AL, who would have been capable of opposing these tendencies in an authoritative and decisive fashion, left the scene and were scattered throughout the whole country. ${ }^{47}$

One of the key issues that was discussed repeatedly by the Main Directorate in the first months of 1957 was how to interpret the activities of the anti-communist underground after 1944. The debates were made complicated by the intertwining of the histories of the AK and WiN - substantial numbers of people who had fought in the Home Army's wartime resistance later joined the anti-Soviet militias after 1945. Chairman Janusz Zarzycki and general secretary Kazimierz Rusinek protested against accepting former members of WiN into ZBoWiD. In March, Rusinek declared that the Main Directorate should not recognize the membership in ZBoWiD of individuals who had not been officially rehabilitated by a court. ${ }^{48}$ His statement was strongly criticized by other members of the Main Directorate. Tadeusz Hołuj stated that Rusinek was expressing his 'private opinion'. Marian

45 For further detail see: Błażej Brzostek and Joanna Wawrzyniak, 'Wiklina. Z historii pewnej kawiarni czasów małej stabilizacji', in Janusz Żarnowski (ed.), Metamorfozy społeczne, vol. 2, Warszawa 2007, pp. 233-257.

46 'Notatka w sprawie ZBoWiD-u. Wydział Propagandy i Agitacji KC PZPR', 27 November 1957, AAN, KC PZPR VIII, 368, p. 2.

47 'Ocena działalności niektórych wrogich elementów b[yłej] AK-WiN w ZBoWiD-zie, Warszawa, 26 września 1957. Z-ca Naczelnika Wydz. I Dep III MSW, mjr Kamiński', AIPN, MSW II, 3854.

48 'Stenogram Krajowej Narady Związku Bojowników o Wolność i Demokrację', 29 March 1957, AZGZKRPiBWP 3, 102, pp. 8-10. 
Soltysiak, during the war a leader of a Home Army group in Kielce region and later an important local figure in that area, commented: 'Had I known that such an idea would come out of the Directorate, I would have arranged to stay in Warsaw, for now I am afraid to return to Kielce. I say this not because I want to sow panic, but because I simply want to emphasize that this sort of approach will be met with a terrible response. ${ }^{49}$

He also drew attention to the fact that he himself, like all the other members of the presidium of the regional directorate in Kielce, had not yet been rehabilitated. Even Adam Kuryłowicz, one of the deputy chairmen of the Main Directorate, disagreed with Rusinek: 'we should demand that these people be [rehabilitated] as a matter of priority, because these are the best sons of Poland. These people reached out for their weapons at the hour of direst need and fought against our enemy.' Kuryłowicz was rewarded with applause. ${ }^{50}$ Mieczysław Moczar also suggested that some members of WiN could be accepted into ZBoWiD. He focused especially on the figure of Antoni Heda, famed for his attack on a communist prison in Kielce in 1945, as follows: 'in 1944, he did a good job fighting the Germans, but later, through our own fault, he was involved in the storming of prisons. ${ }^{51}$

Reports from the provinces showed that widespread access to $\mathrm{ZBoWiD}$ for members of WiN and even the $\mathrm{NSZ}^{52}$ had become a genuine problem for the organization's new leadership. The absence of ideological unity in an area so important for the legitimacy of the entire political system was an indication of the scale of the crisis. The stance of the presidium of the Main Directorate was undoubtedly negative; however, the individuals taking part in the extended sessions had diverse opinions. Again, the statements of Mieczysław Moczar are illustrative. During a session of the Supreme Council in 1956 he argued that 'members of the NSZ cannot belong [to ZBoWiD] under any guise; ${ }^{53}$ however, he is reported in the minutes of a meeting in March 1957 to have been of a different opinion: 'on the matter of the NSZ, [Moczar] believes that not enough attention is given to this organization. It has a lot of well-minded people and a lot of sympathizers in the regions. ${ }^{54}$

49 Ibid., p. 85.

50 Ibid., p. 33

51 'Protokół z posiedzenia Plenum ZG ZBoWiD', 1-2 March 1957, AZGZKRPiBWP 3, 33, p. 12. Antoni Heda was released from prison thanks to support from Mieczysław Moczar. See Antoni Heda, Wspomnienia “Szarego”, Warszawa 1991, p. 300, 301.

52 See footnote 19 in Chapter 2.

53 'Stenogram z posiedzenia Rady Naczelnej ZBoWiD', 19-20 December 1956, AZGZKRPiBWP 3,16, p. 306.

54 'Protokół z posiedzenia Plenum ZG ZBoWiD', 1-2 March 1957, AZGZKRPiBWP 3, 33, p. 12. 


\section{ZBoWiD in the provinces: the case of Lublin region}

Events in Lublin voivodeship illustrate the situation in the provinces and the difficulties faced by the central authorities of ZBoWiD as they attempted to wrest control of the organization. On 11 November 1956, the anniversary of Poland's gaining independence in 1918, an impromptu congress of ZBoWiD in Lublin elected a new regional directorate. Colonel Jan Wyderkowski, a professional serviceman who had fought in the AL during the war, became the regional head. However, the most important figure in the new leadership, the driving force behind later developments, was the new secretary, Władysław Zdunek. Then in his fifties and a member of the PZPR, Zdunek was born into a peasant family near Lubartów, was imprisoned by the Sanacja regime several times on account of his communist activity, cooperated with the Soviet partisans in Volhynia during the war, and joined the AL in 1944. After the war, he was an active member of the PPR and worked in agricultural enterprises. ${ }^{55}$ Zdunek was present at the December session of the Supreme Council and was elected to the Main Directorate of ZBoWiD. In the late 1950s he willingly assigned himself a mission to unite Polish communism with the legacy of the Home Army.

At meetings of the Main Directorate, Zdunek put on the agenda the deportation of Home Army partisans to the USSR in 1944 and 1945: 'Who will repay them now, not only for the material damages, but also the moral?'56 Opening the January congress in Hrubieszów, attended by approximately 1,500 people, Zdunek asked members of the Security Service to leave and demanded the rehabilitation of the AK partisans. ${ }^{57}$ Representatives of the ad hoc commission went to the prosecutor's office to check official documentation and evaluate for themselves whether the accusations against the Home Army's members were legitimate. When the Secretariat of the Main Directorate expressed dissatisfaction at this wilfulness, Zdunek replied in writing: 'we will not permit the discrediting of our decisions, which are correct and in the general interest, because you have no legal or moral grounds on which to do so'; 'it is just a shame that the temporary Main Directorate, which was inspired by the spirit of October [1956, i.e. the Thaw], is beginning to alienate itself from that spirit. The road does not lead that way, colleagues!'

55 'Ankieta personalna, Zdunek Władysław, syn Michała', AZGZKRPiBWP 3, 156/2, p. 33, 34.

56 'Protokół z posiedzenia Plenum ZG ZBoWiD', 1-2 March 1957, AZGZKRPiBWP 3, 33, p. 4.

57 'Notatka informacyjna dot[ycząca] działalności elementów byłego podziemia AK WiN, NSZ, grup bandyckich i peeselowskich na bazie ZBoWiD, mjr A. Mickiewicz', Lublin, 17 April 1957, AIPN 00231/182, 1, p. 59. 
Zdunek demanded that the Secretariat disband itself and that a second ZBoWiD congress be called as soon as possible..$^{58}$

The Lublin directorate quickly - in comparison to other regions - restored its field infrastructure. Rallies and elections were held across the counties in January and February 1957. Attendance at county-level congresses ranged between 200 and 2000 delegates. Most of them made the journey willingly and at their own expense..$^{59}$ The congresses discussed the violation of the rule of law by the Stalinist authorities, the harmful treatment of the Home Army and Peasants' Battalions, the necessity of providing genuine welfare for widows and orphans, and the maintenance of military burial sites. By March of that year, fourteen county-level directorates had established their own headquarters. Since there was no centralized funding available, entertainment events were organized which managed to raise significant resources, sometimes enough to hire full-time staff. ${ }^{60}$

On the whole, these initiatives remained within the limits of permissible activity. However, the central authorities were concerned about the makeup of the newly elected county directorates, which included former members of the NSZ and WiN. Security Service officials were disquieted: 'ZBoWiD is losing its rightful character and is becoming a legal base for the running of enemy work,' stated the deputy commander of the Civic Militia in Lublin, Major Mickiewicz, in March 1957. ${ }^{61}$ These reports indicate that bonds between WiN and the NSZ were being rekindled; former members of both organizations had been released from prison by official amnesty and were now engaging in political activity. Functionaries of the Ministry of Internal Affairs portrayed these organizations using a characteristic image of an internal enemy, and this fact makes it difficult to distinguish the different groups that participated in these local power games or to identify the strategies they used. On the one hand, the Security Service recognized that the formulaic distinction between the 'acceptable' AK and

58 'List z 25 czerwca 1957 od ZO w Lublinie do ZG ZBoWiD w Warszawie. Podpisali sekretarz Władysław Zdunek i wiceprzewodniczący Jan Jabłoński’, AZGZKRPiBWP 3, 156/1, p. 172.

59 A rally in Radom in February 1957 was attended by approximately 3,000 people. At the last moment, the local transport division refused to provide cars. Yet some of the delegates arrived on foot, despite the cold. It appears that representatives of the local authorities left the scene to avoid any recriminations. The congress came in for particularly strong criticism from Kazimierz Rusinek for its insubordination. 'Stenogram z Krajowej Narady ZBoWiD', 29 March 1957, AZGZKRPiBWP 3, 102, p. 148.

60 'List z 28 lutego 1957 od Z[arządu] O[kręgowego] w Lublinie do ZG ZBoWiD w Warszawie', AZGZKRPiBWP 3, 156/2, 3, 102, pp. 30f.

61 'Notatka informacyjna Zastępcy Komendanta Wojewódzkiego MO do Spraw Bezpieczeństwa w Lublinie, mjr A. Mickiewicza', 29 March 1957, AIPN, MSW II 3860 , p. 25. 
$\mathrm{BCh}$ and the censured WiN and NSZ was artificial. On the other hand, they demonized their opponents by attributing similar subversive statements to all of them. Nonetheless, there is no doubt that after the elections, most county directorates included individuals who had been identified as threats to the party apparatus and government.

According to the secret police, the former partisans in ZBoWiD with the greatest authority among the local population were: Stefan Kwaśniewski, the former leader of a several-dozen strong AK-WiN division in the area of Hrubieszów; ${ }^{62}$ Zenon Jachymek, a sabotage officer in Tomaszów Lubelski and deputy commander in the territory of Hrubieszów; ${ }^{63}$ and Captain Marian Gołębiewski, a paratrooper, head of the Kedyw (sabotage department) of the Zamość Inspectorate, commander of the AK in Hrubieszów, chief of staff of the Lublin region, and member of the first High Command of WiN (he was an AK leader in battles against the Ukrainian Insurgent Army, but later tried to cooperate with them against communists). ${ }^{64}$ Gołębiewski travelled from Warsaw especially to attend ZBoWiD meetings. Kwaśniewski and Gołębiewski were elected to the ZBoWiD directorates in Hrubieszów, Jachymek in Tomaszów. Taking up positions of leadership, they all brought with them their former subordinates and sympathizers, who filled the majority of official positions in their counties. The secret police believed that in this way, ZBoWiD was being infiltrated by many individuals who had, in the 1940s, murdered soldiers of the Red Army and Polish Armed Forces, UB functionaries and PPR activists, as well as their families.

From the perspective of the party, the situation was even worse in other towns. The counties of Bychawa, Kraśnik, Biłgoraj and Janów Lubelski came under the influence of the NSZ. In Bychawa, out of fourteen members of the local directorate, eleven were recorded as having been AK members, but according to a note prepared for ZBoWiD, 'the majority fought in divisions of the NSZ. Some of them have on their records the murders of Jews and activists of the AL and PPR. ${ }^{65}$ Former NSZ partisans dominated the directorate in Kraśnik. A Ministry of Internal Affairs report claimed that several ZBoWiD members in the Kraśnik area: 'pretend[ed] to have been AK member[s], but [in fact used to be] in the NSZ.' The officer who drafted the report was rather critical about them. A resident of Dzierzkowice was supposed to have murdered the leader of the local directorate of the Union of Polish Youth (Zwiazek Młodzieży Polskiej, ZMP) and the family of a forestry worker; he was also suspected of robbery. He had not been convicted

62 Rafał Wnuk, Lubelski Okręg AK-DSZ i WiN. 1944-1947, Warszawa 2000, p. 75

63 Ibid., p. 264, 265.

64 Grzegorz Motyka, Rafał Wnuk, Pany i rezuny. Wspótpraca AK-WiN i UPA 1945-1947, Warszawa 1997, p. 85, 195.

65 Ibid., p. 168. 
because he had been recognized as mentally ill; he then broke out of hospital. Another individual had been sentenced for 'the murder of citizen Banasik, whom he gunned down in the market square in Zaklików, as well as for several murders of MO functionaries in Modliborzyce i Zaklików, which he carried out together with his band.' Yet another had 'collaborated during the occupation in the killing of four members of the AL, who were murdered in his courtyard. ${ }^{66}$

In Biłgoraj, the officer filing the report had tracked down two former NSZ partisans. One of them had supposedly been 'in a band until 1947, then [was] interned in the Soviet Union. He killed a village administrator during the occupation and after the war murdered another one, as a result of which he was arrested, but released due to lack of evidence.' The other had on his record 'murders and armed assault. In 1946 he was sentenced to ten years in prison, [and] was incarcerated until 1953. Does not have a place of work, but carries out illicit trade, for which he was arrested in 1955 and spent six months in prison. ${ }^{97}$ In Janów Lubelski, only one former member of the NSZ was noted - however, it was the chairman of the local ZBoWiD chapter. As late as October 1957, statements to the effect that 'we will soon get rid of the communists' were still being noted. ${ }^{68}$

If the reports of the secret police are to be believed, the aim of these former partisans in Lublin voivodeship was the de-communization, broadly understood, of the local power structures. They intended to fulfil this aim by removing, branding as criminals, and punishing those whom they believed to be guilty. They treated ZBoWiD as a field institution in the public realm that could be commandeered in order to bring about social justice. ${ }^{69}$ The former partisans frequently criticized the PZPR and doubted whether it could be reformed. The records of the local Civic Militia office in Tomaszów contain a statement that: 'ZBoWiD has taken on a form of activity whereby it wants to bear responsibility for the fate of the county. In relation to this, opinions have been expressed repeatedly that no party or national council is currently governing, and that ZBoWiD is in charge.' In one of the nearby villages, 'the commander of the WiN grouping and a collaborator of the 'Burta' band, now a member of ZBoWiD, organized on his own initiative a civic meeting where he stated that members

66 'Notatka służbowa, Lublin, 28 marca 1957, St. Ofic. Oper. Wydziału VI Departamentu II MSW, por. Cz. Banas', AIPN, MSW II 3860, p. 111, 112.

67 Ibid., p. 112.

68 'Informacja dot[ycząca] wrogiej działalności w ZBoWiD na terenie tut[ejszego] województwa przez elementy o reakcyjnym obliczu', Lublin, 1 October 1957, AIPN 00231/182, 1, p. 90.

69 'Notatka informacyjna dot[ycząca] działalności elementów byłego podziemia AK WiN, NSZ, grup bandyckich i peeselowskich na bazie ZBoWiD, mjr A. Mickiewicz', Lublin, 17 April 1957, ibid., p. 63. 
of the party have ruled for long enough; now we are in charge, not them.' He also demanded the expulsion of an agricultural procurement officer from his workplace on the grounds that he was 'a Stalinist who had requisitioned grain from people for obligatory deliveries. ${ }^{70}$

At the same time, attitudes to the new country's new leadership were ambivalent. Whereas local party cells were treated with suspicion, former combatants did harbour some hope in the national government. A myth of Władysław Gomułka as a good manager of the country gained prominence: 'he has returned to us our rights as Poles'; 'if the Authorities will be with the People, then the People will support the Authorities. ${ }^{71}$ Jerzy Hubenek's speech at the January congress of ZBoWiD in Kraśnik featured a favourable evaluation of the changes that had taken place in the country. This faith, however, was not unconditional:

We trust in the new leadership of the Party and Government, but we desire that the leadership also place its trust in us ... From our side, we can assure the Party and Government that we will not allow anybody to take from us our achievements both past and future, even if that means preparing for a battle like in Hungary [in 1956]. We are certainly no less accomplished at fighting and know how to die, both for our own freedom and for that of others. ${ }^{72}$

The arguments for national sovereignty and freedom coexisted with economic demands. An association of former partisans in Grabowiec demanded: 'punishment of those guilty of breaking ribs and bones', 'rehabilitation of those wrongly sentenced', and the erection of a monument to Polish partisans in Hrubieszów; in addition, they appealed for supplies of building materials, a halt to collectivization, statutory welfare benefits for those affected by Stalinism, and the organization of craft workshops ${ }^{73}$ People who were skilled at dealing with such everyday issues tended to enjoy increased authority in local communities. As the author of a secret report in Hrubieszów county noted: 'Many reactionary leaders are running manufacturing enterprises (concrete panels, bricks, lime, etc.) under the guise of the Union, which gives them significant resources and facilitates contact with grassroots members. ${ }^{97}$

70 Ibid., p. 63.

71 'Informacja ze Zjazdu Powiatowego ZBoWiD w Hrubieszowie', Lublin, 6 February 1957, AZGZKRPiBWP 3, 156/1, p. 161, 162.

72 'Protokół z Walnego Zjazdu ZBoWiD z 12 stycznia 1957 r. w Kraśniku w sali Domu Ludowego', AIPN, 00231/182, 1.

73 'Rezolucja', n.d., AZGZKRPiBWP 3, 156/1, p. 163.

74 'Informacja dot[ycząca] wrogiej działalności w ZBoWiD na terenie tut[ejszego] województwa przez elementy o reakcyjnym obliczu', Lublin, 1 October 1957, AIPN, $00231 / 182,1$, p. 79,80 . 
The events of 1957 in Lublin voivodeship bore the hallmarks of a social movement. The bombastic phraseology of national consciousness was combined with political and economic demands, which had specific resonance at the local level. Anonymous denunciations and Interior Ministry files provide a crooked reflection of public life at this time, but they are the only evidence available. They feature reports about neighbours and show mutual animosities and attempts to settle local scores. A former leader of WiN left politics for a period because he was busy planning his revenge on his wife's lovers. He could not bear the fact that 'she, a Polish woman, [had] given herself to members of the party. ${ }^{35}$ The files of the secret police also make it clear that politics could also be tied to alcohol: 'after drinking a few vodkas, $\mathrm{K}$. started on his political programme, he often does that he wants everyone to listen to him, and he gets intoxicated on his own speech. ${ }^{76}$ A restaurant manager named 'E.M.' regularly hosted his former commanders: 'he was never sparing with vodka. During loud celebrations, hostile words about the Party and the Government of People's Poland could be heard. ${ }^{77}$

The atmosphere at such a local meeting is conveyed by an account of what took place on 13 June 1957 in Parczew. Jan Kwiatkowski, the chairman of the county directorate who had been elected only the previous winter, received a message from the local party branch a few days before a planned meeting, stating that new elections would be held on that day and that he would be ousted him from his position. The formal reason given, based on anonymous denunciations, was that he had defrauded welfare funds and parcelled out the money among his friends (Kwiatkowski denied the allegation in his response to the Main Directorate).$^{78}$ It appears, however, that the real reason behind these accusations was a resolution of the Parczew branch of ZBoWiD, signed by Kwiatkowski, that had been sent to the local party office only a week before the planned meeting. It featured phrases such as: 'we are in full accord with the Eighth and Ninth Plenums of the Central Committee, but we must point out that the People's Republic of Poland is not your fiefdom, and not only people from the PZPR have a right to it. We also have rights. ${ }^{79}$

Upon entering that meeting in Parczew, the local chairman found many new faces, including local party officials and people who had arrived from neighbouring counties. According to the minutes, the first to speak was a certain

75 'Doniesienie, Źródło A. Przyjął B. Dudek', Lublin, 6 August 1958, AIPN 00231/182, 1, p. $105,106$.

76 Ibid., p. 107.

77 Ibid.

78 '[List do] Kom[itet] Centralny PZPR w Warszawie', Parczew, 24 May 1957, AZGZKRPiBWP 3, 156/2, p. 76.

79 'Protokół z posiedzenia rozszerzonego Prezydium ZBoWiD w Parczewie', 7 June 1956, AZGZKRPiBWP 3, 156/1, p. 165. 
'K.L.', who 'starts to say something about widows and orphans and that his comrades do not agree with him. He wants to articulate some inebriated thought, can't formulate it, and sits down.' After him, 'E.K.' took to the floor: 'tries to stay on his feet, asks where the money for the widows and orphans went ... The speaker is drunk, gesticulates, loses his thread and begins to speak again.' A number of subsequent speakers made addresses in favour of either the Home Army or the party. A demand was made for the removal of 'German snoops'. Someone else defended the secretary of the Parczew chapter of ZBoWiD against accusations whose substance can be inferred as relating to murder or to theft of Jewish property: ${ }^{80}$ 'if he was guilty of anything and acted immorally during the occupation, Jews returning from the forest after the liberation would have liquidated him.' The congregation was also interested in how one participant had amassed 'so much gold' during the war. Towards the end of the session, the director of a local dairy-producing cooperative arrived, 'claiming that he hadn't been invited to the meeting, and that they were bossing events.' The alcoholfuelled atmosphere conditioned a chaotic exchange of opinions. The minutes end with the words: 'pub brawl'. ${ }^{81}$

Towards the end of 1957, an article appeared in the newspaper Trybuna Ludu ('The People's Rostrum') that sharply criticized the leadership of ZBoWiD in Lublin for not being in control of its area and allowing people from WiN into county directorates. Hrubieszów, Tomaszów Lubelski, Bychawa, Kraśnik and Lubartów were singled out as towns that had fallen into disrepute. ${ }^{82}$ This was a clear sign that the party authorities had decided to affect changes to the existing situation. In August of that year, Władysław Zdunek was expelled from the party by a resolution of the Provincial Committee. He was accused of having ignored the guidelines of the ZBoWiD Main Directorate on verification and antiSemitism, and of having close contacts with people who opposed socialist power 'with weapons in hand. ${ }^{93}$ The Secretariat of the Main Directorate of ZBoWiD also described Zdunek's activity as being in contravention of the Eighth and Ninth Plenums of the PZPR Central Committee. It argued that Zdunek had built factions, encouraged county directorates to rebel, and stood on the side of former soldiers of the Home Army and Peasants' Battalions who had not been

80 Parczew was a site of anti-Jewish violence in February 1946, organized by a detachment of WiN.

81 'Protokół z posiedzenia plenarnego powiatowego zarządu ZBoWiD w Parczewie', 13 June 1957, AZGZKRPiBWP, 3, 156/2, pp. 44-48.

82 A. Mariańska, 'O sprawach lubelskiego ZBoWiD-u', Trybuna Ludu, 25 June 1957, p. 3.

83 'Informacja dot[ycząca] wrogiej działalności w ZBoWiD na terenie tut[ejszego] województwa przez elementy o reakcyjnym obliczu', Lublin, 1 October 1957, AIPN, 00231/182, 1, p. 81 . 
rehabilitated by the courts. The Main Directorate recommended the removal of Zdunek, the reorganization of the regional directorate, and the appointment of another communist, Paweł Dąbek, the chairman of the provincial National Council, to the post of the chairman of the regional directorate. ${ }^{84}$ In November 1957, General Zarzycki could already state:

How much time, energy and trouble the anarchical antics of comrade Zdunek in Lublin have cost us. How much time, how many meetings were needed to deal with this nonsense, with this political irresponsibility, with this political demagogy, which has overflowed in giant waves from the regional directorate in Lublin. ${ }^{85}$

Increased intervention from the central powers coincided with a decline in interest in ZBoWiD on the part of people with connections to WiN and the NSZ. In August 1957, a Security officer reported that many participants in recent events had begun to distance themselves from the changes: two activists in Krasnystaw county, 'utmost critics who have been blasting socialist power, Ch.W. from Tarnawka and A.S., now believe that it is not worth getting involved.' The following year, these tendencies became more pronounced. A former officer of the Home Army in Lublin region said that he 'didn't see any political opposition currently, and in such a situation, in his opinion, there is no point in spitting into the wind. ${ }^{96}$

One of the most representative accounts of Lublin voivodeship in 1958 was left by a man recorded only as source ' $\mathrm{A}$ ':

The whole of society can be divided into two groups: anti-Soviet and pro-Soviet. The majority of people, from the urban intelligentsia to the peasantry, hates the USSR. People everywhere have had enough of the USSR interfering in our internal affairs and not letting us build our own socialism. After October [1956], this matter took on a different hue, because thanks to comrade Gomułka the PZPR has gained trust with most of the masses. However, in recent times this trust has heavily declined. People say that comrade Gomułka must belong to the USSR politically, because he is surrounded by old admirers of Russia like comrade [Zenon] Nowak and others, who have complete control over comrade Gomułka. This is believed not only by people from the erstwhile underground, but also party members ... I have noted that these are statements made by simple folk, who had nothing to do with the former underground, and who, by making such statements, are now trying to be seen as 'good blokes', as they say, by the former conspiracy activists. I have noted that they

84 'Prezydium Zarządu Okręgowego ZBoWiD. Wnioski w sprawie opanowania sytuacji w Okręgu Lubelskim ZBoWiD, Warszawa, 25 sierpnia 1957, sekretarz Zarządu Głównego, Henryk Matysiak', AZGZKRPiBWP 3, 156/2, p. 26, 27.

85 'Stenogram z posiedzenia Plenum ZG ZBoWiD', 12 November 1957, AZGZKRPiBWP 3, 34, p. 139.

86 'Informacja dot[ycząca] wrogiej działalności na terenie woj. lubelskiego po zagadnieniu AK-WiN w ostatnim okresie, Lublin, 10 marca 1958. Naczelnik Wydziału III KWMO w Lublinie, mjr B. Dudek', AIPN, 00231/182, 1, p. 93. 
talk about such issues of their own accord. They don't believe there will be another war, but are negatively disposed to the USSR, although they defend Khrushchev as a good politician. People understand that today war would not be in their interests, that war would mean annihilation of mankind and for this reason they have no desire for hostilities. [Former partisans] argue that the atom bomb won't be needed, and Russia will be dismantled from within. They say that we must give up Szczecin and Wrocław, and regain Lwów and Wilno in return. They predict that in the long term these changes will take place gradually over a number of years. For this reason, they are inclined to try to make money by all kinds of means. G. works in a cooperative which makes prefabricated products - apparently he makes 5,000 złoty a month. He is full of life and verve. He is preparing to buy gold and dollars, as he intends to escape abroad ... In Grabowiec, I visited P.R. and his group. He is a person who sees in his work only the triumph and wellbeing of our society. He founded in Grabowiec a truly excellent co-operative (making bricks and concrete panels). This is a man who doesn't think about the war, but only yearns for peace and wellbeing for all. ${ }^{87}$

In this way, ' $A$ ' was essentially describing the beginning of the era of 'small stabilization' 88 - the transition from the active discussion of public matters to the quiet, inward-facing realization of private goals. However, examining these events in Lublin, historian Andrzej Friszke has argued that the explosion of patriotic expectation among former combatants in October 1956 was the basis for the formation of a 'partisan faction' in the national leadership in the 1960s. According to him, the events of 1956 and 1957 showed that the 'social foundations were present and that the ideological formulae were already in place.' ${ }^{89}$ To a certain extent, this hypothesis explains the evidence well. The popularity of patriotic slogans, sometimes tinged with anti-Semitism, was observable during the Thaw, as was the demand that national ideology be mixed with the theme of the war. The results of the activity of the communist Władysław Zdunek from Lublin voivodeship also show that local alliances were possible between partisan factions that had been hostile to each during the war. It is worth pointing out once more that Mieczysław Moczar, an active participant in the changes taking place at ZBoWiD in 1956 and 1957, modified his opinion several times on the issue of the NSZ. Nonetheless, the positing of a genealogical relationship between the veterans' Thaw and the emergence in the 1960s of a nationalist movement within the PZPR and state apparatus is problematic. What happened in 1956 and 1957 was a chaotic social

87 'Doniesienie, źródło A. Przyjął B. Dudek'. Lublin, 6 August 1958, AIPN, 00231/182, 1.

88 The term 'small stabilization' (mała stabilizacja) comes from a play by Tadeusz Różewicz, Świadkowie albo nasza mała stablizacja ('Witnesses, or Our Small Stabilization', 1962). It also serves as a sarcastic comment on the 1960 s that stresses empty political rituals and boredom in public life.

89 Andrzej Friszke, 'Przystosowanie i opór. Rozważania nad postawami społecznymi 19561970’, in Tomasz Szarota, p. 147, 148. 
movement, a series of spontaneous and undirected activities. Diverse groups of memory gained a voice, expressing different and sometimes opposing demands. Some patriotic activists did not see any way of cooperating with the communists. Other circles distanced themselves from nationalist ideas, whereas many groups were interested primarily in economic and material questions or the possibility of conducting commemorative activity, not necessarily connected to any broader ideological concept.

\section{The Myth of Unity: Formation}

\section{The 'family of combatants' and criteria for verification}

During the Tenth Plenum of the party Central Committee in November 1957, Roman Werfel, the editor of Nowe Drogi ('New Routes'), the party's main ideological journal, stated that the necessary revision of official attitudes towards the Home Army had been transformed into a dangerous apotheosis of the organization. The party writer Jerzy Putrament spoke with a similar message, protesting against 'festivals of the AK in the press. ${ }^{90}$ Shortly before this event, the leadership of ZBoWiD had started to gain control over the situation within the Union, and had taken two fundamental decisions of a practical character.

Firstly, they declined the demand for a restructuring of the organization as a federative one. It was thus decided that the territorial structure, with its tendency to atomize groups, would be retained. The related decision to refuse to reinstate the heraldry of the organizations that had preceded ZBoWiD added a symbolic accent. According to Rusinek: 'It is not currently possible to sort out the matter of the return of the flags, most of which were transferred to local museums, and which all represent different organizations. We must act as a single organization under the banner of ZBoWiD. ${ }^{91}$ At the same time, something of a compromise was offered in the form of permission to establish committees that would deal with specific issues faced by different groups within the organization. It was, however, characteristic that only four committees were founded that would work under the Main Directorate. These were committees representing minor groups: the Dąbrowski brigade, veterans of revolutionary struggles, veterans of the Wielkopolska Uprisings and veterans of the Silesian Uprisings. Committees of the wartime resistance movement and prisoners could only function under

90 Mieczysław F. Rakowski, Dzienniki polityczne. 1958-1962, p. 73.

91 'Protokół z posiedzenia Plenum ZG ZBoWiD' 1-2 March 1957, AZGZKRPiBWP 3, 33, p. 1. 
regional directorates. Janusz Zarzycki explained this decision in plain terms in January 1959: 'the creation of central commissions representing such powerful groups within the Union would effectively mean the creation of two [more] Main Directorates, which would undermine the existing Main Directorate, and so the Main Directorate does not want to agree. ${ }^{92}$ Moreover, the provincial committees of the resistance movement effectively camouflaged the wartime identities of the various groups. As Kazimierz Rusinek stressed:

When we speak of a group commission of the resistance movement, we don't mean to divide this movement into former soldiers of the AK and AL. We wish, comrades, to see in this movement and in this commission everyone who has the right to belong to it, irrespective of which military formation or partisan movement they belonged to during the fight against the occupier. ${ }^{93}$

As time passed, several cliché phrases went into circulation to describe ZBoWiD's situation. On the one hand, 'centrifugal forces', 'anarchy' and 'antics' were the order of the day, yet on the other hand, 'ideological unity' was fought for and had to be 'cemented' in order for 'one family of combatants' to emerge. The Main Directorate took specific measures to create a 'family of combatants'. One was an (unsuccessful) attempt to introduce obligatory attendance at monthly group meetings. ${ }^{94}$

Besides retaining the territorial structure of ZBoWiD, the Main Directorate made a second important decision to rationalize the criteria for belonging to the Union, thereby clarifying its attitude to WiN and the NSZ. It issued working procedures for verification in July 1957. In November, at a plenary session of the Main Directorate, Janusz Zarzycki led the creation of a Main Verification Commission and also officially announced the postponement of the next congress until verification had been completed: 'We are a social organization made up of people who fought for freedom and democracy, and in this very fact lies the definition of ZBoWiD as a left-wing Polish organization, and we will never espouse a right-wing conception,' he said. He added that 'the Union is against the social right wing, against its attempts to shatter peace and draw the people into a whirlwind, against the programme to restore capitalism.' Using harsh words, he disowned the NSZ: 'We didn't have a Quisling, ${ }^{95}$ but there was the NSZ, which

92 'Stenogram z posiedzenia Rady Naczelnej ZBoWiD', 21 January 1959, AZGZKRPiBWP 3,17, p. 158 .

93 'Stenogram Krajowej Narady Związku Bojowników o Wolność i Demokrację', 29 March 1957, AZGZKRPiBWP 3, 102, p. 13.

94 'Stenogram z posiedzenia Rady Naczelnej ZBoWiD', 21 January 1959, AZGZKRPiBWP 3,17 , p. 10 .

95 References to the Norwegian politician Vidkun Quisling (1887-1945), who formed a proNazi puppet government during the Second World War, were a popular figure of speech 
worked with the Gestapo, murdering patriots from other divisions, murdering Jews who had escaped from the ghetto, murdering Soviet prisoners-of-war, the NSZ which retreated together with the Germans... We will not have these people in our Union.' 'Those are not our traditions,' he added, suggesting that court sentences hanging over former NSZ members should still be considered lawful. In relation to $\mathrm{WiN}$, he was rather more subdued: 'this was a conspiracy within the AK. WiN was made up of people whose anti-Sovietism and nationalism blinded them from the interests of the Polish people. ${ }^{96}$ The chairman of ZBoWiD stated that under specific circumstances, former members of WiN could be admitted into the Union. He explained that their youth, lack of experience, and vulnerability to the influence of their leaders could be mitigating factors. He demanded, however, that former members of WiN hold a self-critical view of their past and a positive attitude to the 'people's regime, to socialist construction. ${ }^{97}$

\section{'Let's do patriotism'}

Keeping the structure of ZBoWiD and clarifying the conditions of membership were not enough. In the changed political situation, the Union also needed a positive concept. The idea of the 'Resistance Movement' (often written with capital letters, Ruch Oporu) became a new unifying myth. It reprised certain aspects of the myths of the Stalinist era: for example, ZBoWiD's new ideological formula was founded on the notion of mass resistance during the German occupation, like in the early 1950s. However, explicit revolutionary tropes were replaced by a combined socialist and patriotic rhetoric. Kazimierz Rusinek, who was prone to eruptions of pathos during Union meetings, quoted (somewhat inaccurately) the celebrated Polish Romantic poet Juliusz Słowacki: $9{ }^{8}$ 'They went forth, crying "Poland, Poland" | Then God appeared from behind Moses' bush | He looked at the people shouting and asked: "Which Poland?"' Rusinek argued that the Union must answer firmly: 'socialist Poland.' He emphasized that 'we neither think nor want to oppose the idea of Poland to the idea of Socialism because in our deepest

in Poland. The phrase 'Poland bred no Quislings' (Polska nie wydała Quislinga) was supposed to mean that the Poles formed no official structures that collaborated with the Nazi state.

96 Ibid., p. 6, 7.

97 Ibid., p. 16, 17.

98 Juliusz Słowacki (1809-49) is considered one of the greatest Polish poets, alongside Adam Mickiewicz (see footnote 61 in Chapter 2). Rusinek had in mind the poem Szli krzyczac: 'Polska! Polska!' ('They went forth, shouting "Poland, Poland!”, 1848), which underscores quarrels among the Polish political emigration in the early nineteenth century. 
convictions we know that these ideas are not and will not be contrasting, indeed the opposite. They define each other mutually. ${ }^{99}$ The changes that had occurred after 1944 were to form the basis of unity between diverse veterans' groups, because socialism had led to the achievement of 'true' independence:

Members of our organization can have different opinions on how the world came to be, whether or not God exists, or whether Marxism-Leninism is the only correct theory. We are not a political party after all, no matter how we recognize the leading role of the PZPR. But when it comes to independence [the sovereignty of Poland after 1944], we must have a single, clear position. ${ }^{100}$

In contrast to the Stalinist myth of victory over fascism, the myth of the unity of the resistance movement was inclusive and patched over the differences in worldview and experience that had divided groups during the war. 'In our region, there is no difference whether a man was in the $\mathrm{AK}$ or the $\mathrm{BCh}$ or the AL. Everyone was a member of the resistance', said a representative of the directorate in Opole. ${ }^{101}$ The concept of the internal enemy and the repudiation of nationalist military groupings such as the Home Army, which had been characteristic of the totalitarian era, were replaced by an attempt to appropriate their legacy under the sign of military unity.

Colonel Jan Szaniawski, formerly a partisan in the AL, chairman of the regional directorate in Warsaw, described the situation in the capital, saying that before 1956 there were two divisions of ZBoWiD in Warsaw: one in the city centre, and one in the Praga district on the other side of the Vistula River. 'In the centre, it was empty and nothing was happening. Just once a week, on a Thursday, our comrades, political prisoners from 1905, came to try our consciences, because I never saw anyone else at the organization except them.' Between 1956 and 1957, things became significantly livelier, so the directorate decided to introduce a cycle of meetings divided between different groups so as to maintain order. Subsequently it attempted to bring those groups together as a united whole. For example, in the Żoliborz district, it tried to establish a new group consisting of both AL and AK partisans who participated in the Warsaw Uprising; Szaniawski gave it the politically neutral name 'the Żoliborz Insurgents'. ${ }^{102}$ The actions taken by the regional directorate in Warsaw serve as a model example of how history was reconstructed and ideas changed, from revolutionary patriotism to national communism. Several years later, another official of this directorate, the former Dąbrowski soldier Jerzy Welker, informed

99 'Stenogram z posiedzenia Rady Naczelnej ZBoWiD', 19-20 December 1956, AZGZKRPiBWP 3, 16, p. 208.

100 Eugeniusz Kuszko, 'Podstawowe zagadnienia ideologiczne w życiu ZBoWiD [1958]', AZGZKRPiBWP 3, 35, p. 120.

101 'Stenogram z Krajowej Narady ZBoWiD', 29 March 1957, AZGZKRPiBWP 3, 102, p. 106. 102 Ibid., p. 123, 124. 
the Supreme Council that 'a new type of ZBoWiD member has developed, a new activist', and that members valued 'our activists not for the group he represents within the Union, but for what actual work he does.' 103

Yugoslavia - one of the enemies in Stalinist times - was an important model in building the myth of unity. ZBoWiD established links with the Union of Fighters in the War of National Liberation in Yugoslavia. Kazimierz Banach described the impressions of a travelling delegation to the country as follows:

The leaders of Yugoslavia have succeeded in involving all of the patriotic elements that fought in the Second World War in the building of socialism, thanks to targeted and conscious efforts. The issue of the war is held by society to be of great importance, an issue for which one must have respect. ${ }^{104}$

The Main Directorate believed that the abundance of monuments and memorial plaques in Yugoslavian cities and villages provided an excellent example for Poland to follow. Henryk Matysiak highlighted the extent to which such commemoration was missing in Poland: 'The situation of villages is more terrible than during the occupation. No trace of celebrating their heroic deeds in any way. Secretaries of provincial committees [of the PZPR] do not even know which villages have been awarded the Grunwald Cross for heroism. ${ }^{105}$

The Union quickly became an important lobbyist for commemoration at sites of battle and loss of life. By January 1959, with the participation of ZBoWiD, 450 sites had been marked with monuments and other commemorative symbols. This was also the period in which the mass aesthetic of ubiquitous memorial sites - still visible throughout Poland today - had its origins, i.e. the usually modest symbols such as a plaque on a wall where a battle or massacre took place, or a memorial stone in the centre of a town or city that suffered persecutions. ${ }^{106}$ The Main Directorate of ZBoWiD described its actions as follows:

Our aim is for these places to become the object of a national cult. In spots visible to Polish tourists and foreigners, by highways and roads, there should be hundreds and thousands of memorial stones, inexpensive monuments, oak trees, ${ }^{107}$ and plaques on schools that bear witness to the history of our people's liberation war and teach subsequent generations respect for our best traditions. ${ }^{108}$

103 'Stenogram z posiedzenia Rady Naczelnej', 21 June 1961, AZGZKRPiBWP 3, 18, p. 173.

104 'Stenogram z posiedzenia Plenum ZG ZBoWiD', 27 May 1957, AZGZKRPiBWP 3, 36, p. $23,24$.

105 Ibid., p. 19.

106 These memorials also drew on practices of the immediate post-war period. See: Mazur, pp. 133-157.

107 In Poland, oak trees are often considered symbols of strength, endurance and tenacity.

108 'Informacja z działalności Zarządu Głównego ZBoWiD za wrzesień 1959-kwiecień 1961', AZGZKRPibWP 3, 38, p. 16. 


\section{Związek Bojowników o Wolnośc i Demokracje w SIERADZU}

Corocznie miedzynarodowy Ruch Oporu organizuje w kwietniu obchody rocznicy wyzwolenia $z$ hitlerouskich obozów koncentracyjnych i zwycięstua nad faszyzmem. Na miejscach walk i stracen, rozsianych po calej Europie, zbiorą się b. uczestnicy Ruchu Oporu, b. kombatanci, b. więźniowie hitleryzmu by uczcić pamięć milionów ofiar faszyzmu i wojng.

Zamanifestują oni suą wiernosé ideałom Ruchu Oporu i swą solidarność z patriotami innych narodów, którym droga jest sprawa pokoju, sprawa niepodległości i suwerenności krajów ojczystych i wolności demokratyczngch.

\section{Związek Bojowników o Wolność i Demokrację w Sieradzu}

Organizuje urocxystosci:
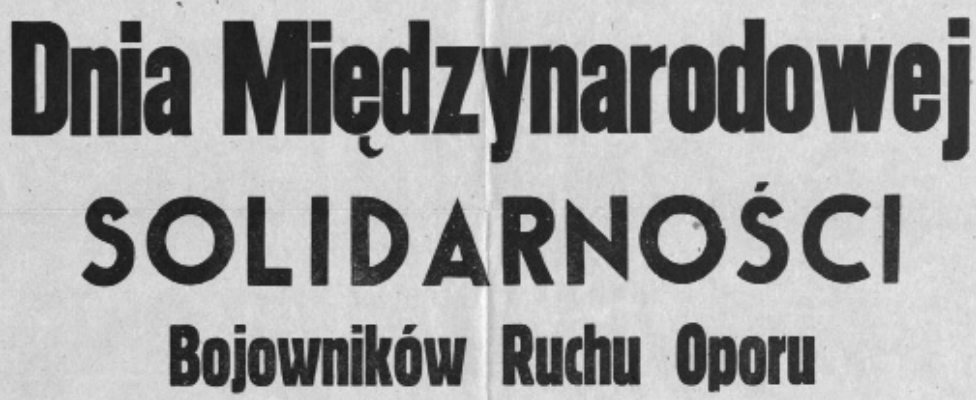

\section{W niedziele dnia 14 kwietnia $1957 \mathrm{r}$.}

\section{Program obchodu:}

godzina 11-ta Zblóka ze sztandarami I wiehoami organizaoll spolecznych, oroanizacji miodziezowyoh, miodzlezy szkoine), spoleczenstwa okolloy I mlasta Sleradza na Plaou Gen. świerozewaklego.

godzina 11,1s Przemowienie.

godzlna 11,30 Przemarsz z wiencaml ullog Kosoluszki na omentarz wojekowy gdzie na grobach poleglych zostana zlozone wlence,

Pozatym zlozenle Wiencow nastapl w mlelscu stracen na bolsku sportowym, przed pomnikiem wdzięcznosci i cmentarzu katollckim.

Skladająo hold ich pamięci zobowlązemy sle uroczyłcle, ze oddamy wszyskle swe slly, aby utrwalló odzyskana kosztem tylu oflar woinosó I niepodleglośc Polekle] Rzeczypospolltej Ludowej.

Zarząd Dddziału Z. B. o W. i D. w S i erad $\mathbf{z}$ u

4.1 Notice of celebrating a Day of International Solidarity of Resistance Fighters, Sieradz, April 1957. National Library of Poland. 


\section{ZWIAZEK BOJOWNIKÓW O WOLNOŚĆ I DEMOKRACJE OKRĘG GDANSKI \\ ZARZAD WOJEWODDZKI}

\section{W dniu 19 czerwca 1958 r.}

W sali Stowarzyszenia Architekłów Polskich w Gdańsku Targ Węglowy 27 (Strzelnica św. Jerzego)

\section{zostanie otwarta}
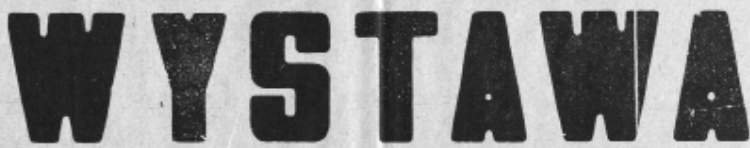

p. t.

\section{"Zbrodnie faszyzmu}

\section{hitlerowskiego $\mathrm{w}$ dokumentach"}

Dokumenty l eksponaty na wystawie oskarżaja faszyzm hitlerowski za zbrodnie dokonywane na bezbronnej ludności $z 24$ państw osadzonych w wiezieniach i Obozach Koncentracyjnych

Wystawa czynna będzie codziennie od godz. 10-tej do godz. 20-tei w dniach od 19. VI. -8 . VII. 1958 r.

ZWIAZEK BOJOWNIKOWW O WOLNOSC I DEMOKRACE OKREG GDANSSKI

ZARZAD WOJEWÓDZKI

4.2 Notice of the opening of a travelling exhibition: 'Documents of Hitlerite Fascist Crimes'. Organizing such events was characteristic for ZBoWiD in the late 1950s and 1960s. Gdańsk, June 1958. National Library of Poland. 
Another practice that was begun on a large scale was the giving of commemorative names to institutions. The Main Directorate had, after all, demanded 'balance and economy in the funding of monumental and costly memorials.' It therefore suggested that commemorative activities be aligned with the building of schools and other public premises, in order to find a way of 'paying tribute to the dead by laying plaques, naming schools after heroes of the liberation struggles, etc.' ${ }^{109}$

Symbols of memory alone were not enough. It was also necessary to write the history of the Resistance Movement. An Office of the History of ZBoWiD was established (it later became the Historical Commission of ZBoWiD) and was tasked with collecting documentation, popularizing the history of the resistance, and publishing. One of its first publications was a brochure entitled 'Writing Memoirs and Reminiscences: Guidelines for Participants of the Partisan Struggle'. Matysiak recommended unequivocally that writers should not limit themselves to the history of the People's Army:

Concerning the creation of history, let us not repeat the mistakes of previous years, whereby when people talked about the past it was only possible to mention three names. There was the GL and AL, Krasicki, Sawicka and Nowotko, and no one else. Let us do patriotism for the living and the dead. ${ }^{110}$

Not everyone was satisfied with the principal role of the Resistance Movement. A former serviceman from Koszalin protested without mincing his words: 'I constantly hear about the resistance, the resistance, the resistance ... as if the resistance movement defeated Hitler. The resistance achieved a great deal, but how about a little about the soldiers? The honourable gentlemen from the resistance should remember that if the soldier hadn't arrived, the resistance movement would have been moving and resisting for a long time yet. ${ }^{111}$ However, the legend of the Polish Armed Forces in the East fighting alongside the Red Army did continue to be important - moreover, it had a vital social dimension in the formerly German western provinces (where Koszalin is situated), where a policy of preferential treatment was in place for military settlers.

At the same time, soldiers who had fought in the Polish Armed Forces in the West began to be looked upon more favourably, and some of them decided to return to Poland. The legends of their battles ${ }^{112}$ were incorporated into the official narrative. In this way, as well as through the addition of important lieux de mémoire related to the 1939 defensive campaign, the symbolic geography of war memory was

109 'Sprawozdanie z działalności ZBoWiD, grudzień 1956-październik 1958', AZGZKRPiBWP 3, 35, p. 70 .

110 'Stenogram z Krajowej Narady ZBoWiD', 29 March 1957, AZGZKRPiBWP 3, 102, p. 168.

111 Ibid., p. 57.

112 Most notably their participation in the Battle of Britain (1940) and the Battle of Monte Cassino (1944). 
expanded. According to the religious metaphor employed by a communist general Eugeniusz Kuszko: 'this soldier of Kutno, of Westerplatte, ${ }^{113}$ what moral strength he gave to the people, when the people were being tortured and mistreated, nailed to the cross!' ${ }^{114}$ In 1960, Paweł Dąbek, a former Majdanek camp prisoner, one of most prominent communists in Lublin region, and the chairman of local chapter of ZBoWiD, said: 'the issue of the 1939 campaign is immensely popular in society, as much as the resistance against occupation, and it brings our Union closer to society. ${ }^{115}$ These histories were presented together with increasing regularity, as the shared fates of Polish soldiers who were bound by 'blood sacrifice' for their fatherland. This was a reversal of Stalinist symbolism, for which September 1939 was the paradigmatic example of the defeat and weakness of the capitalist state. The author of an article on this subject in Za Wolność $i$ Lud wrote:

The war was started in September 1939 and ended victoriously in May 1945. The People's Army of Poland had the privilege in this war of fighting for the liberation of its native land and entering the enemy's capital city bearing its military banners of victory. In Poland after its rebirth, the banners of September 1939 have regained their glory and honour. They have become a valued part of the history of the September campaign, which has entered the treasure vault of the Polish Armed Forces' glorious deeds. ${ }^{116}$

Legends surrounding soldiers, however, were secondary to the myth of the unity of resistance behind enemy lines. In 1958, the authors of a report on the activities of ZBoWiD evaluated the contents of Za Wolność i Lud positively, recognizing that the journal correctly 'illustrated both problems of the past and the current policies of ZBoWiD.' The materials examined by the report, covering nearly two years of publication, show that the largest quantity of texts (one in four) concerned the partisan movement and the resistance in Poland, with around half of these dealing with the history of the GL/AL (see Table 4.1). Fewer articles (16\%) were dedicated to the traditions of the Polish Armed Forces in the West and East. A similar amount of material was written about the concentration camps, which had been so prominent in Stalinist times, and which also frequently thematized the heroism of the resistance movement and of prisoners.

113 The Battle of Westerplatte near Gdańsk (Danzig) at the beginning of September 1939 started the German invasion of Poland. Fewer than 200 Polish soldiers defended the Westerplatte peninsula for seven days, a feat that became an important symbol of heroic Polish resistance. The Bzura River battle near Kutno (9-12 September), which delayed the capitulation of Warsaw, also gained a similar symbolism.

114 Eugeniusz Kuszko 'Podstawowe zagadnienia ideologiczne w życiu ZBoWiD [1958]', AZGZKRPiBWP 3, 35, p. 124.

115 'Stenogram z posiedzenia Plenum ZG ZBoWiD', 28-29 October 1960, AZGZKZRPiBWP 3, 40, p. 73.

116 Kazimierz Satora, 'Sztandary pułkowe z września w muzeum oręża polskiego', Za Wolność i Lud 9 (1959), p. 14, 15. 
Table 4.1 Content of articles in Za Wolność i Lud, by theme (January 1957 - September 1958)

\begin{tabular}{|l|c|c|}
\hline Theme & Number of articles & $\%$ \\
\hline Current affairs at home and abroad & 25 & 12 \\
\hline History of the pre-war workers' movement & 24 & 11 \\
\hline History of the pre-war peasants' movement & 7 & 3 \\
\hline History of the GL and AL & 24 & 11 \\
\hline History of the AK & 8 & 6 \\
\hline History of the BCh & 10 & 4 \\
\hline History of other organizations of the Resistance Movement & 34 & 5 \\
\hline Traditions of the Polish Armed Forces & 13 & 6 \\
\hline The Polish movement abroad & 34 & 16 \\
\hline $\begin{array}{l}\text { Crimes of Hitlerism, the Resistance Movement } \\
\text { in concentration camps }\end{array}$ & 22 & 10 \\
\hline Current issues of ZBoWiD & 214 & 100 \\
\hline Total & & \\
\hline
\end{tabular}

Source: 'Sprawozdanie z działalności ZBoWiD, grudzień 1956 - październik 1958'. AZGZKRPiBWP 3, 35, p. 69. Themes and layout of table as in the original.

\section{Anti-German attitudes}

The myth of the unity of the resistance movement had a distinctly anti-German flavour to it. This motif had been present in previous years, but its function changed after 1956: it was designed to unite rather than divide. In the Stalinist period, false accusations of collaboration with the Nazis had provided a pretext for arrest. After the onset of the Thaw, the myth of an all-national fight against the 'Hitlerite occupier' allowed the verification commissions of ZBoWiD to turn a blind eye on individual histories of membership in the anti-communist underground. Anti-German attitudes also served to screen memories of the Soviet occupation, and thereby to justify the fact that Poland was in the Soviet sphere of influence. The idea that the USSR was the guarantor of Poland's western border, which the FRG refused to recognize, was constantly voiced. Nearly every official speech by Union representatives began with the same political preface: protesting against the remilitarization of the FRG, emphasizing the urgency of preserving the border at the Oder-Neisse line, asserting the moral imperative of capturing Nazi war criminals, and appealing that crimes of genocide should not fall under the statute of limitations. These speeches sometimes included references to 'western imperialism' as a continuation of Nazism, but in much milder tones than 
in the Stalinist epoch. Germany now became the fundamental and self-contained national enemy of Poland.

An anti-German stance was one of the Gomułka government's most important resources in its claims for internal legitimacy because it strongly resonated with popular Polish attitudes at the time. ${ }^{117}$ Meanwhile, in the 1950s, Chancellor Konrad Adenauer oversaw a policy of 'democratization through integration', which was based on evasion of the problem of German responsibility for the crimes of the Third Reich, avoidance of war crimes trials, pressurizing the allied countries to grant amnesties to people who had been sentenced, and tolerating the presence of former Nazis at nearly all levels of the state administration and the military. ${ }^{118} \mathrm{~A}$ communist journalist and editor, Mieczysław F. Rakowski, no doubt with sincere indignation, wrote in his diary in October 1958:

In the elections for the Landtag of the province of Schleswig-Holstein, the torturer and destroyer of Warsaw and famous general of the SS Heinz Reinefarth ${ }^{119}$ has gained a seat. For the atrocities he committed against the population of our capital, he was personally honoured with the highest of medals by Hitler, a Knight's Cross of the Iron Cross with Oak Leaves. And that's how it is in Germany. An entire herd of unpunished Hitlerites is running around the FRG. When our press writes about the lack of justice for this scum, [they] scream that we Poles are anti-German. ${ }^{120}$

At the turn of the decade from the 1950s to the 1960s, the FRG began to change its policy regarding the Nazi past, but facts such as the creation of the Central Office of the State Justice Administrations for the Investigation of National Socialist Crimes (Zentrale Stelle der Landesjustizverwaltungen zur Aufklärung

117 E.g. Jerzy Holzer, 'Uraz, nacjonalizm, manipulacja. Kwestia niemiecka w komunistycznej Polsce', Rocznik Polsko-Niemiecki 1 (1992); Jadwiga Kiwerska, 'W atmosferze wrogości (1945-1970)', in Anna Wolf-Powęska (ed.), Polacy wobec Niemców. Z dziejów kultury politycznej Polski 1945-1989, Poznań, pp. 45-93; Piotr Madajczyk, 'Die Rolle antideutscher Instrumentalisierungen in Polen, 1944-1989,' in Dieter Bingen, Peter Oliver Loew and Kazimierz Wóycicki (eds), Die Destruktion des Dialogs. Zur innenpolitischen Instrumentalisierung negativer Fremdbilder und Feindbilder, Polen, Tschechien, Deutschland und die Niederlande im Vergleich, 1900-2005, Wiesbaden 2007, pp. 137f; Zaremba, pp. 304f.

118 Herf, pp. 267-333.

119 In early August 1944, during the Warsaw Uprising the units of Heinrich Reinefarth (1903-79) and Oskar Dirlewanger (1895-1945) murdered nearly 60,000 civilians of Warsaw. After the war Reinefarth became the member of the Schleswig-Holstein Landtag and the successful mayor of the town of Westerland. Despite demands, he was not extradited to Poland. In 2014, after the release of a book by Philipp Marti, Der Fall Reinefarth (Neumünster 2014), the representatives of Landtag and Westerland publicly apologized for Reinefarth's past and expressed their sorrow for the fact he was among the Land's authorities.

120 Mieczysław F. Rakowski, Dzienniki polityczne. 1958-1962, p. 48. 
nationalsozialistischer Verbrechen) in Ludwigsburg, or the opening of archives in Berlin for the purposes of conducting trials, were hardly mentioned in the Polish press because they contradicted the message it was trying to convey. Furthermore, the Polish government found itself in an awkward position when it tried to use ZBoWiD for the purposes of spreading anti-German sentiment. The Union was tasked with obtaining material reparations from West Germany for former concentration camp prisoners. Such reparations were among the most important issues on the international political agenda in the 1950s and 1960s. On the one hand, the propaganda section of ZBoWiD carried out its assigned political function: at meetings both in Poland and abroad, Union members highlighted the scale of wartime trauma suffered by camp inmates, and pointed to the FRG's reluctance to offer compensation. ZBoWiD's deputy chairman Adam Kuryłowicz emphasized that the Polish representative at FIR should categorically demand damages for former prisoners 'from no one else, not from the Polish government, but from Germany. The Germans must pay, and not the Polish government. We would never request such reparations from our own citizens, and we never will., ${ }^{121}$ On the other hand, the legal context of this situation was very complex, and frequently worked against the propaganda of the Polish authorities. In 1953, the government of Poland had signed, under pressure from Moscow, a declaration in which it renounced any claims to German reparations (this declaration was intended to relate to the GDR only, but did not say so explicitly). West German law allowed for citizens of third countries to apply for damages on an individual basis, but the absence of diplomatic relations between the FRG and Poland constituted a barrier for Polish citizens. The so-called Hallstein Doctrine made it impossible for the FRG to maintain diplomatic relations with states that recognized the GDR. ${ }^{122}$

It was against this background that $\mathrm{ZBoWiD}$ started a propaganda campaign in Poland, under which it collected applications for reparations from IG Farben Industrie on behalf of former inmates of Auschwitz-Birkenau (the campaign was treated as a pilot scheme conducted before further claims would be made on behalf of prisoners at other camps and persons deported to the Third Reich for forced labour). ${ }^{123}$ The organization also employed lawyers who represented the interests of victims in the FRG. This episode ended in a fiasco for the Polish side, but was used for political purposes well into the 1960s. The second group of victims represented by ZBoWiD were the victims of pseudo-medical experiments

121 'Stenogram z posiedzenia Plenum ZG ZBoWiD', 27 May 1957, AZGZKRPiBWP 3, 36, p. 22.

122 Jarząbek, passim; Krzysztof Ruchniewicz, Polskie zabiegi o odszkodowania, passim.

123 'Stenogram z posiedzenia Rady Naczelnej ZBoWiD', 19-20 December 1956, AZGZKRPiBWP 3, 16, p. 61. 
at Ravensbrück. This was the first Polish group to obtain any kind of damages from West Germany: in the late 1950s, the FRG agreed to pay compensation to these individuals, although it was described as 'financial assistance' rather than 'reparation'. ${ }^{124}$

However, the use of the reparations issue for the purposes of internal legitimacy did not meet the approval of the prisoner groups themselves, who considered that excessive politicization of the matter could hinder the search for a viable solution to this very real problem. Tadeusz Holuj criticized both ZBoWiD and FIR in relation to this matter. He proposed on several occasions that ZBoWiD should join other, non-communist international victims' organizations. He likely meant the International Free Federation of Deportees and Internees of the Resistance (FILDIR), which had a solid record of obtaining German compensation for victims of the war in Western European countries. ${ }^{125}$ Hołuj believed that co-operation with FILDIR was in the material interests of former camp prisoners in Poland, because this organization was recognized by the government of the FRG, unlike FIR:

This perhaps a most drastic and most shameful example, because it is a question of money, but I believe that it is much easier to reach an agreement in a situation where concrete action is taken... Issues like medical treatment, scholarly work on the concentration camps, reparations, even the capture of concrete criminals of the SS can lead to greater proximity between the organizations - not declarative fighting against the Federal Republic of Germany. ${ }^{126}$

124 A likely reason behind this development was that the Hiroshima Peace Committee began to publicize the stories of the Ravensbrück victims; the UN Economic and Social Council and International Red Cross also intervened in their favour. After the signing in 1970 of a treaty to normalize mutual relations between West Germany and Poland, the German Red Cross paid a further 100 million marks to other victims in reparations. For more detail on reparations, see: Dieter Bingen, Polityka Republiki Bońskiej wobec Polski. Od Adenauera do Kohla 1949-1991, Kraków 1997, pp. 142-145; Jarząbek, 'Władze Polskiej Rzeczypospolitej Ludowej wobec problemu reparacji i odszkodowań', pp. 85-103; Dominik Sołtysiak, 'Podstawy prawne i implementacje odszkodowań niemieckich dla polskich ofiar eksperymentów pseudomedycznych w latach 1945-1989', in Witold M. Góralski (ed.), Problem reparacji, odszkodowań i świadczeń w stosunkach polsko-niemieckich 1944-2004, Warszawa 2004, vol. 1, pp. 269-194; Katharina Stengel, 'Competition for Scant Funds: Jewish, Polish, and Communist Prisoners of Auschwitz in the Negotiations for the Wollheim Agreement', Norbert Wollheim Memorial 2010 (www.wolheim-memorial.de, accessed May 2015); Ruchniewicz, Polskie zabiegi, pp. 97-131.

125 'Stenogram z posiedzenia Plenum ZG ZBoWiD', 27 May 1957, AZGZKRPiBWP 3, 36, pp. $10 f$.

126 'Stenogram z posiedzenia Rady Naczelnej ZBoWiD', 21 January 1959, AZGZKRPiBWP 3,17 , p. 96. 
The fear of inciting anti-Semitic attitudes was another barrier to finding a political solution to the issue of reparations. In the West, Jewish survivors were represented by various associations (in particular, the Conference on Jewish Claims against Germany) as well as the state of Israel, which received material assistance and financial compensation in accordance with the Reparations Agreement between Israel and West Germany, signed in Luxembourg in 1953. Tadeusz Hołuj argued that in Poland, publicizing the fact that Jewish organizations were receiving damages could lead to an explosion of anti-Semitism amongst non-Jewish former camp inmates. He told of how, at the International Auschwitz Committee, 'a rumour, or an opinion, started going round the Polish delegates that the Polish side had been led into an error so that it would not hurry things before the Zionist organization put forward its claims for compensation. ${ }^{127}$ In the opinion of the presidium of the Main Directorate of ZBoWiD, the declaration by the Claims Conference that Polish citizens of Jewish extraction would be included in its reparations campaign would further aggravate attitudes among non-Jewish Poles. ${ }^{128}$ The issue of reparations therefore became a point of contestation in the rivalry between two martyrologies, Polish and Jewish. At the time, however, giving publicity to such conflicts was avoided - unlike during the late 1960s (see Chapter 5).

\section{The Second ZBoWiD Congress}

The second ZBoWiD Congress, held in the late summer of 1959, was the culmination of the changes that had recently taken place. By this time, the party leadership had gained control of the political situation in the country (the Third Congress of the PZPR took place in March 1959). The position of the communist authorities had also stabilized in the provinces, as it had within ZBoWiD. In January 1959, there were 375 local chapters and 595 groups. ZBoWiD had around 120,000 active members. However, according to information supplied by Janusz Zarzycki, the composition of ZBoWiD did not fully reflect the ideological primacy of the resistance movement. The most numerous group was the former concentration camp prisoners $(40,000$ members $)$, with the resistance movement in second place (35,000 members). The records do not indicate how many of these were former Home Army soldiers; in all probability, this information was intentionally omitted, in order to better accent the 'unity' of the resistance. There

127 'Stenogram z posiedzenia Plenum ZG ZBoWiD', 27 May 1957, AZGZKRPiBWP 3, 36, p. 13.

128 'Protokół z posiedzenia Prezydium ZG ZBoWiD', 9 January 1958, AZGZKRPiBWP 3, 88 , p. 26. 
were around 22,000 soldiers from various parts of the armed forces. Others, such as the participants of the Wielkopolska and Silesia Uprisings, veterans of the 1905 revolution, and soldiers of the Dąbrowski brigades, made up the other $23,000 .{ }^{129}$

The election campaigns in the lead-up to the Congress featured local meetings of regional and county branches, with the participation of party committee representatives, activists of the Front of National Unity and officers of the Polish Armed Forces. Information provided in official reports shows that these meeting prior to the ZBoWiD Congress were conducted peacefully and without incident. Officials of the Ministry of Internal Affairs noted, however, that many former Home Army fighters who had been previously active in the Union boycotted the elections. ${ }^{130}$

Elections took place firstly at the level of the county, then the voivodeship. As a result, nearly 800 delegates were chosen to attend the Congress. ${ }^{131} \mathrm{In}$ addition to the ZBoWiD delegates, the Congress Hall of the Palace of Culture and Science in Warsaw was filled with younger soldiers of the Polish Armed Forces, representatives of youth organizations, and delegations from 35 foreign associations of former combatants and prisoners.

Of the regional delegates, the largest contingent was made up of members of the resistance movement (42 percent), in which the AL and AK had the biggest shares (16 percent each). 25 percent of delegates were former concentration camp prisoners, 18.5 percent were soldiers, and a further 14.5 percent comprised of other groupings: insurgents of Wielkopolska and Silesia, veterans of the revolutionary struggles, Dąbrowski fighters and Polish soldiers who had fought in the Red Army. Nearly 60 percent of all delegates were members of the PZPR, and the cities of Warsaw, Katowice and Poznań were the best represented areas. ${ }^{132}$ Thus, the composition of the congress neither reflected the wartime balance of power nor the make-up of ZBoWiD at the time, where former prisoners were the most numerous group. It was however a reflection of a compromise to which the country's leadership had agreed.

129 'Stenogram z posiedzenia Plenum ZG ZBoWiD', 6 May 1959, AZGZKRPiBWP 3, 37, p. 5,6 .

130 'Informacja, Warszawa 13 sierpnia 1959. Z-ca Naczelnika Wydz. I, Dep. III, major R. Kamiński, Oficer Oper. Wydz. I Dep. III ppor. J. Łabędzki’, AIPN, MSW II, 3854, p. 43.

131 'Program II Ogólnokrajowego Kongresu Delegatów ZBoWiD i Obchody 20 Rocznicy Najazdu Hitlerowskiego na Polskę', Za Wolność i Lud 9 (1959), p. 5.

132 'Wykaz ilościowy delegatów na II Kongres ZBoWiD według przynależności partyjnej i środowiskowej. Oprac. ppor. J. Łabęcki’, AIPN, MSW II 3854. 


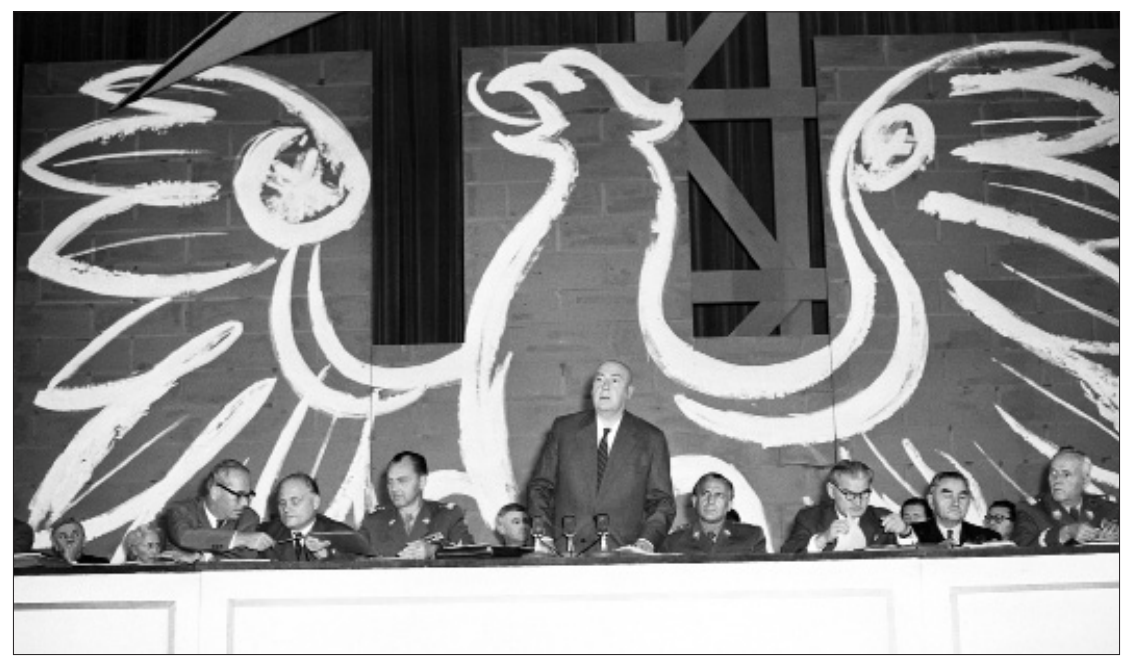

4.3 Second Congress of ZBoWiD, a view of the presidium: Józef Cyrankiewicz is addressing the audience; to his right: Janusz Zarzycki. Palace of Culture and Science, Warsaw, 1959. Photo by Mariusz Szyperko, National Digital Archives/Polish Press Agency.

The Congress took place on 1-3 September 1959, similarly to the Unification Congress, i.e. on the anniversary of the invasion of Poland by Nazi Germany. ${ }^{133}$ However, this time it was not commemorated as a defeat, but as the beginning of a successful struggle for independence. The official event poster and the iconography of the presidium contained the national symbol, the white eagle, and the words 'the Polish people were victorious'. Three exhibitions added to the ideological packaging of the Congress. The biggest, on the main square in front of the Palace of Culture and Science, was entitled 'Poland under Hitlerite Occupation' and showed war crimes against the civilian population and the activities of the resistance movement. It also reminded viewers that there were still Nazi criminals at large in the FRG. ZBoWiD published an album to accompany the exhibition, bearing the title 'We Remember' and featuring similar material. The Museum of the Polish Armed Forces in Warsaw had a display which recounted the history of 'the September Campaign', whilst the International Press and Book Club ran an exhibition on the history of Warsaw in the years 1939-45. A Resistance Movement Film Week complemented the Congress, and anti-war demonstrations were held

133 The delegates elected a new leadership. Janusz Zarzycki became the chairman, Kazimierz Rusinek the general secretary, and Henryk Matysiak his deputy. The deputy chairmen positions were filled by Kazimierz Banach, Jan Izydorczyk, Włodzimierz Lechowicz and Zygmunt Netzer (an AK representative in the ZBoWiD presidium). 
in all of the provincial capital cities, as well as in Gliwice, Kutno, Westerplatte, Majdanek, Radogoszcz, Oświęcim, Dobiegniewo, Rogoźnica and many towns on the East German border. Throughout the country, public readings were held on war-related themes, and the Western Institute in Poznań organized an academic conference on the 'Hitlerite Aggression against Poland'. ${ }^{134}$

The main slogan of the Congress was 'unity'. The idea of 'consolidation', despite there having been 'divisions in the past', was prominent in speeches by Kazimierz Rusinek, Generals Zarzycki and Moczar and other officials, as well as in an address by Prime Minister Cyrankiewicz at a reception at the Presidium of the Council of Ministers. The Congress combined communist and nationalist themes, making them mutually complementary: 'the national struggle against Fascism proceeded on the tracks laid by the socialist history of our country, on the mobilization of the broadest masses to fight for the freedom of the people and to decide on the form to be taken by the new Poland. ${ }^{135}$ The communists were presented by speakers as the originators and nucleus of the Polish resistance movement. The programme of the PPR was conceived as having been politically realistic and therefore effective, unlike the programme of the Polish government-in-exile in London and the Home Army Main Command. Nonetheless, thanks were given to all: the soldiers of the 1939 defence war, the Polish Armed Forces in the East and West, the Home Army, the People's Army, the Peasants' Battalions, and other partisan organizations. Meanwhile it was emphasized in all manner of ways that:

Blood shed in the African desert has the same value as blood shed on the Pomeranian Wall, in the Warsaw Uprising or in the partisan fighting in the Lipskie Forests ${ }^{136} \ldots$ [Nonetheless,] the heroism, courage and blood of some provided the basis for the bankrupt politicians of the bourgeoisie to carry out a senseless and fruitless policy of anti-Sovietism and social conservatism that was doomed to failure from the outset, whilst the blood and bravery of others became the foundation for the advancement of Polish democracy. ${ }^{137}$

The Congress also outlined the basic tasks of $\mathrm{ZBoWiD}$ on the international stage. These included working towards world peace, reducing tensions in international relations, encouraging disarmament, campaigning to outlaw the nuclear bomb, issuing warnings about 'attempts to revive fascism and racism', and working to liberate nations that were yearning for freedom and resisting 'imperialism and colonialism'. The Union would also strive for the strengthening of the new border with Germany and draw attention to the 'rebirth of Prussian militarism'. The main

134 II Kongres ZBoWiD 1-3 września 1959, Warszawa 1959.

135 Ibid., p. 53.

136 Lipskie and Janowskie Forests (Lasy Lipskie and Lasy Janowskie), ca $80 \mathrm{~km}$ south of Lublin were sites of major partisan struggles with Germans in June 1944.

137 Janusz Zarzycki, 'Głosimy prawdę o Polsce', Za Wolność i Lud 9 (1959), p. 3. 
outcomes of the Congress were reconfirmed by a 'Resolution on the peaceful co-existence of nations' passed at the colloquium of the International Resistance Movement, which took place on 5 September after the conclusion of the main events of the Congress.

Importantly, the Congress did not restrict itself to ideological statements. The approved resolution included a statement that 'providing support to members and beneficiaries of ZBoWiD is one of the most important statutory tasks of the Union.' A series of social welfare decisions were passed, and the resolutions contained pledges that further efforts would be made to improve everyday living conditions for former combatants (the next chapter discusses some of the major consequences of this decision). The organization's statute was changed, providing the basis for the issuance of new regulations on verification. The changes included a decision to make ZBoWiD membership available to 'participants of the fight against reaction' and to functionaries of the post-war security organs and police who had fought against the Ukrainian Insurgent Army and the Polish pro-independence underground. This was an important ideological step towards weakening the position of the Home Army.

A report of the Ministry of Internal Affairs compiled opinions of former AK soldiers overheard in the corridors at the Congress. Some accepted the unifying message of the speeches. Others believed that the authorities were merely trying to use the popularity of AK in order to gain legitimacy within society. The opinion was also voiced that the speeches played down the impact of the changes the Union had undergone in recent years. The most critical delegates believed that the Congress was 'choreographed from start to finish' by people who could not be trusted: 'Jews and regime sympathizers'. The majority of comments were directed at the issue of material provision for Union members and they revealed once again that the main differences in war experiences between civilian victims and fighters were not eliminated by the rhetoric of unity and heroism. One person declared his anxiety that 'real warriors who fought against the occupier with rifles in their hands will be overwhelmed by new members who had nothing to do with the fight against the occupiers, but merely sat in the camps.' He was also of the opinion that there would not be enough privileges for everyone. Another person believed that 'in these conditions it will impossible to do any work. The Union will be diluted by the enormous number of members, and former members of the Resistance Movement will have no voice.' ${ }^{138}$

138 'Informacja dot[ycząca] komentarzy związanych z II Kongresem ZBoWiD-u, Warszawa, 28 września 1959, oprac. Mjr R. Kamiński, mjr Pawłowicz’, AIPN, MSW II, 3854, pp. 65f. 
Unlike the myth of the victory over fascism during Stalinist times, the myth of unity of the resistance movement created a veneer of Polish togetherness both during the war and in the post-war present. Exclusion and the constant struggle against internal enemies were replaced by an ideal of community. This was a formula which envisioned an 'imagined community' and which altered both the image of the past and of the present by imposing an invented consensus between different groups. It employed an amalgam of communist and nationalist symbolism, by presenting a common front against the single external enemy, the Germans. Its main aim was to legitimize the regime and to stabilize the social circumstances. Patriotism supported internationalism, and the motif of blood shed by partisans in defence of the fatherland substituted the shared blood of Polish and Soviet soldiers. 


\section{Chapter 5 \\ The Myth of Innocence (1960-69)}

\section{Clientelism: 'We Have Been Able to Arrange It'}

In the mid-1960s, the Main Directorate of ZBoWiD changed the location of its Warsaw headquarters; it moved from an inter-war townhouse at 15 Rutkowski Street to a palace on the corner of Ujazdów Avenue and Piękna Street. ${ }^{1}$ The transfer to one of the most prestigious areas in the Polish capital, a neighbourhood of foreign embassies and major state offices, symbolized a growth in the significance of war veterans and former prisoners in Polish public life. Intellectuals who were observing these changes wrote with sarcasm about 'rentiers of the occupation'. 2 This phrase highlighted an important demographic and material change that had come about within the two decades since the war: veterans were aging and increasingly drew benefits from their activity within the Union.

An important feature of the social reality of the 1960s was the modest, but nonetheless real, growth of a socialist welfare state. The reforms that took place within ZBoWiD after 1956 would not have been possible without a change in the state's attitude to the issue of social welfare. In contrast to Stalinist times, the organization began to fulfil important functions in this area, thereby responding to some of the material demands that had been made during the Thaw. ZBoWiD became the distributor of its own financial resources and a lobbyist for the rights of memory groups. At the same time, it was also a monopolist: without membership in the Union, which essentially signified a declaration of loyalty to the communist state, it was impossible to claim any veteran social benefits.

Understanding the functioning of the socialist welfare state requires that we look into its grey zone. The formal activity of almost all state institutions co-existed alongside inter-personal bonds, which formed complex networks of informal influences. These comprised a parallel mechanism of social organization

1 'Siedziby Zarządów Związku Bojowników', in Zbowidowcy. Tradycje i zadania, Warszawa 1969, pp. 395-399.

2 See e.g. comments made by Seweryna Szmaglewska, writer and former Auschwitz prisoner, during a session of the ZBoWiD Supreme Council in November 1963, AZGZKRPiBWP 3 , 19. 
which was secondary to the official structures of the socialist state, and which was spontaneous in nature. The 'networks' of power (uktady) were a characteristic feature of the reality of the time: interest groups whose interaction was based on the principle of mutual favours, as well as bonds between patrons and clients, both undermined the state institutions and stabilized the system as a whole. ' $\mathrm{We}$ have been able to arrange it' ('udało się załatwic') was one of the most common phrases in the everyday jargon of a state functionary, and also of the average Pole, at this time.

So how did veterans function under 'really existing socialism' in actual everyday practice? A group of Main Directorate representatives proudly declared in 1966 that 'we are not alone in our work'; they were announcing that financial or organizational cooperation with party and state structures had been agreed. The party and the armed forces were the most important institutions with which ZBoWiD interacted. ${ }^{4}$ Officials from the various departments of the party regularly consulted with permanent employees of the ZBoWiD Main Directorate, and the Main Political Directorate of the Polish Armed Forces seconded its officers to work for the Union, thereby ensuring effective monitoring of ZBoWiD as well as providing assistance by reducing the number of employees on the Union's payroll. Officials of the PZPR Department of the History of the Party and the Military Historical Institute were in contact with the ZBoWiD Historical Commission. The Office of the Council of Ministers and the Ministry of Finance provided subsidies to support the functioning of the Union and its social welfare programmes. The Ministry of Health and Social Welfare guaranteed the availability of places in sanatoria for ZBoWiD members, as well as priority access to hospitals and retirement homes, and assistance in obtaining foreign medicines. The Office of the Council of Ministers and the Social Insurance Institution considered applications for extraordinary benefits and special allowances. The Ministry of Agriculture cooperated with ZBoWiD to regulate issues related to military settlers. The Ministry of Culture and Art heeded the appeals of Union officials and supplied funds for museums and war-related monuments, and also helped in the promotion of ZBoWiD's activity through the mass media. Whilst the national councils ${ }^{5}$ all over the country allocated funds for the maintenance of sites of battle and loss, they also worked with local ZBoWiD chapters to deal with everyday matters raised by former combatants and prisoners. The Ministry of Justice assisted ZBoWiD's attempts to obtain reparations from West Germany. The Ministry of Education, the

3 Jacek Tarkowski, Patroni i klienci, Warszawa 1994; Dariusz Stola, Kampania antysyjonistyczna $w$ Polsce, 1967-1968, Warszawa 2000, p. 19.

4 'Sprawozdanie z działalności Zarządu Głównego ZBoWiD w 1966 roku', AZGZKRPIBWP 3, 29, p. 9 .

5 National councils (rady narodowe) were local-level municipal governments. 
Union of Polish Scouts, and the Union of Polish Teachers helped in establishing contact with the youth. The Main Commission for Research into Hitlerite Crimes in Poland, the Council for the Protection of Sites of Struggle and Martyrdom, and the Polish Red Cross were natural allies of ZBoWiD in the politics of memory (the former two institutions had, like $\mathrm{ZBoWiD}$, been re-activated after suspension of significant portions of their activity in Stalinist times). Ties with the Polish Tourist and Sightseeing Society, the Orbis travel agency, and other public institutions were also important. In turn, the Union was drafted into state-organized events, such as the commemorations of the thousand-year anniversary of Polish statehood in 1966, or elections to the Sejm (parliament). ZBoWiD representatives sat on the committee of the National Unity Front and the All-Polish Committee of the Defenders of Peace, and they popularized the guidelines produced by congresses and meetings of the Party.

In this way ZBoWiD, which in Stalinist times had been an organization dependent on the discretionary power of the Political Bureau of the PZPR, became an organization with its own position in the network of state institutions. However, this period's social reality was characterized not only by interaction between organizations, but by the fact of individuals occupying multiple positions in different institutions: this was what enabled the exchange of influences and explained the meaning of the aforementioned slogan that 'we have been able to arrange it.'

Take, for example, the ZBoWiD chairmen: Janusz Zarzycki was, as already mentioned, the head of the Main Political Directorate of the Polish Armed Forces before becoming the Mayor of Warsaw in 1960; Mieczysław Moczar was Deputy Minister, later Minister, of Internal Affairs, a position that enabled him to entangle the Union with the most powerful state institution in the second half of the 1960s. The Secretary of ZBoWiD, Kazimierz Rusinek, was also the Deputy Minister of Culture and Art. Ryszard Nazarewicz and Leon Stasiak, frequent guests at ZBoWiD sessions, worked for the Propaganda Section of the PZPR. A lawyer, Janusz Wieczorek, deputy chairman of the ZBoWiD Main Directorate, was the director of the Office of the Council of Ministers and the chairman of the Council for the Protection of Sites of Struggle and Martyrdom. Henryk Jabłoński was the Minister of Enlightenment and Higher Education whilst also occupying the post of the chair of the Historical Commission of ZBoWiD. Bonds and networks also existed at the lower levels of the organization: between representatives of regional and county directorates and officials of local PZPR committees, national councils, museums, etc. For example, in 1966 the presidium of ZBoWiD in the town of Bychawa was composed of: the head of the local mill, an elder of the communal 
cooperative, the head of the personnel department of the county council, a local police officer and the chairman of one of the district councils. ${ }^{6}$

These dependencies facilitated the 'arranging' of matters at multiple levels of the party-state hierarchy. Although serious attempts were made during the $1960 \mathrm{~s}$ to provide a complex package of rights and benefits for former combatants and prisoners, it was only in 1975 that legislation was passed that made this a reality. ${ }^{7}$ Until then, specific demands could be met by ministerial decision, and for this reason, ZBoWiD's most important role was that of a lobbyist which negotiated with government offices and tried to obtain concessions beneficial to its members.

Let us briefly examine what kind of benefits could be secured, and for whom. ${ }^{8}$ Those who did not work, did not receive pensions for the years that they had worked, or received only minimal pensions, could expect that $\mathrm{ZBoWiD}$ would help them to obtain welfare payments by endorsing their applications. Nonetheless, the granting of such assistance and the amount awarded were considerably differentiated. The most privileged groups were the veterans of the revolutionary struggles of 1905 , those who fought in the Spanish Civil War, and communists who fought in the Second World War outside Poland; these groups received pensions at a special rate, which was determined by the Prime Minister himself. Participants of the Silesia and Wielkopolska Uprisings received a monetary supplement to their ordinary pension. Pensions were also available for the widows of men who died fighting in the Second World War and were considerably higher for widows of men who 'died or were murdered in the struggle against the reactionary underground' in the late 1940s. Everyone else, notably including the participants of the anti-Nazi resistance within Poland, could only apply to the Social Insurance Institution for the so-called exceptional pension (renta wyjatkowa), which could occasionally be increased to the level of the special rate.

6 'Arkusze ewidencyjne członków zarządów oddziałów 1965/1966', AAN, ZBoWiD ZG, $1,16$.

7 'Ustawa z dnia 23 października 1975 r. o dalszym zwiększeniu świadczeń dla kombatantów i więźniów obozów koncentracyjnych.’ Dz.U. 1975 nr 34, poz. 186.

8 In the second half of the 1960s, a member of ZBoWiD could also hope to gain priority access to: (1) employment; (2) housing; (3) state subsidies for setting up a kiosk for the sale of newspapers, drinks, or lottery tickets; (4) places in sanatoria and other healthcare institutions; (5) consideration of applications to be recognized as physically disabled; (6) holidays; (7) various benefit payments; (8) places for one's children in nurseries, schools and boarding houses; (9) veterinary help, agro-technical equipment, and banking advice; and (10) building materials. Elderly people who were not in the care of relatives had priority access to retirement homes administered by the healthcare and welfare departments of the national councils. Zbowidowcy, p. 375, 376, 382, 383. See also: 'Sprawozdanie z działalności Zarządu Głównego ZBoWiD w okresie od III Kongresu Związku do 31 grudnia 1965', AZGZKRPIBWP 3, 29, pp. 200 f. 


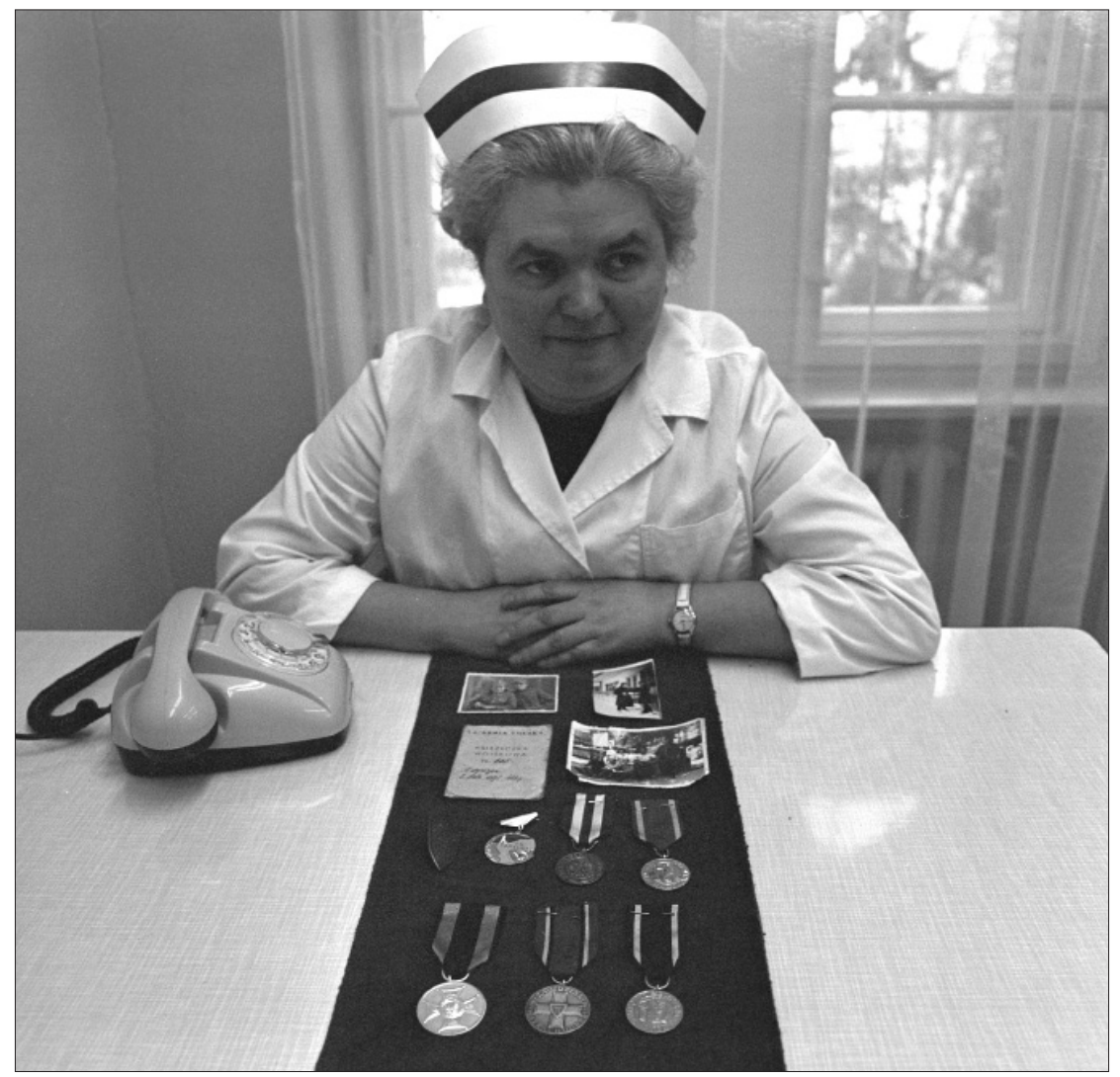

5.1 A head nurse with her war medals. She was responsible for running a home for elderly members of ZBoWiD. Assigning propaganda roles to women was typical for Mieczystaw Moczar. Włościbórz, December 1969. Photo by Stefan Kraszewski, Polish Press Agency.

Significantly, the exceptional pension also applied to members of ZBoWiD who owned their own farm or craft enterprise, i.e. those who were not entitled to a state pension through other channels because of their self-employed status. For this same reason, membership in ZBoWiD could also confer entitlement to free medical treatment for those who were not covered by social insurance - primarily smallholder farmers. Initially, this right was dependent on an individual's income from farming or crafts-making. In 1968, all members of ZBoWiD became eligible if agriculture was their sole source of income.

Although the social protection of soldiers of the armed forces was regulated by the Ministry of National Defence, military settlers were also involved in 
the welfare-seeking activities of ZBoWiD. Responding to pressures from the Union in the early 1960s, the Ministry of Agriculture passed two resolutions that conferred additional rights to settlers. The first extended the duration of preferential conditions; these were previously supposed to expire in 1958. The second resolution extended the eligibility criteria for becoming a military settler to include soldiers of the 1939 defence war who had been interned in PoW camps or had lost at least 20 percent of their earning capability. It was also decided that the rights of the military settlers could henceforth be passed on by inheritance or ceded to close relatives.

It is important to note the background to these policies. Although Poland was a unique communist country where the initial attempt to collectivize agriculture was abandoned after the Thaw, those farmers who were not employed within the system of State Agricultural Farms (Państwowe Gospodarstwa Rolne, PGR) were still excluded from the state system of pensions and health insurance as self-employed. Thus, they were beneficiaries of the Union's ability to 'arrange' social privileges beyond the relatively narrow group of 'professional' communists, to include a broader spectrum of rural residents and private entrepreneurs. In this way, sections of society that had been victimized by the Stalinist regime now gained access to important benefits. The cult of martyrdom of the civilian population and, to a large extent, the later wave of anti-Semitic propaganda were also intended to appeal to the rural masses. In such a way, the veterans' union became a transmission belt carrying the legitimizing ideology from the party to the countryside.

Another demand of the Thaw that was met at this time was the return to the practice (abandoned in the 1950s) of awarding military honours for wartime deeds. Like in Brezhnev's USSR, the conferral of decorations to veterans at state commemorations became one of the fundamental rituals of communist Poland. ZBoWiD was the only organization in the country that had the right to submit nominations to the State Council for military honours. Thus, the Union arranged for representatives from all of the wartime armed organizations to receive awards. The Main Honours Commission of $\mathrm{ZBoWiD}$ was also responsible for the verification of honours conferred during the war by the Home Army Main Command. This was one of the heavy ironies of socialist Poland: the AK commanders were initially demonized as traitors, and then, in the 1960s, they became 'failed politicians'; nonetheless, the honours they had awarded were respected. By 1972, 10,670 military decorations had passed the verification procedure, including 1664 Virtuti Militari orders. In this respect, the year 1966 (the 1,000-year anniversary of the establishment of a Polish state) was the most 'productive': the commission approved almost 8,000 medals, including 6,500 for soldiers of the Home Army, 
1,000 for soldiers of the Peasants' Battalions, and 300 for soldiers of the Polish Armed Forces in the West. ${ }^{9}$

The above examples illustrate that one of the results of the process of detotalitarization in Poland was a rupture in the formation of the social status of veterans. The metaphor of a 'fighter'(bojownik), which was used in Stalinist times, implied that people were not recognized as recipients of material compensation; the emphasis was on their devotion to the political issues of the present day. After 1956, the term kombatant entered into circulation, and to a large extent, it approximated the pre-war concept of the weteran - an individual who was accorded a privileged status and respect within society on account of his or her own wartime achievements. The myth of the unity of the resistance movement resulted in the expansion of the boundaries of the community of veterans: partisans of various armed formations, and even participants of the civilian resistance, were included. A new phrase, 'a combatant of the Resistance Movement' (kombatant Ruchu Oporu) entered usage. ${ }^{10}$

At the same time, the basic functions of the Union in relation to the party-state apparatus changed. Having been a sham organization that fulfilled three essential aims (controlling, atomizing, and mobilizing former combatants for the advancement of the ideological priorities of the state), ZBoWiD became a clientelistic organization. The formation of a patron-client relation between the state and the veterans had benefits for both sides. For the authorities, it facilitated the obtainment of legitimacy; loyalty to the state became ensconced in society, not by violent means, but via monopoly control over social welfare, the awarding of military honours, and the organization of anniversary celebrations. For the veterans and former prisoners, the fundamental benefits were an increase in social prestige and material privileges.

\section{The Partisans}

In September 1964, Mieczysław F. Rakowski, a sharp-eyed observer of political events and then editor-in-chief of the magazine Polityka, a weekly which enjoyed great popularity amongst the intelligentsia, wrote in his Diaries that:

In Warsaw, the latest congress of ZBoWiD, the veterans' organization headed in recent years by Janusz Zarzycki, has come to a close. Now [Mieczysław] Moczar has become the leader, as could have been foreseen. Meanwhile, a number of former partisans like [Stanisław] Wroński, [Mieczysław] Róg-Świostek, etc. have entered the organization's central leadership. The makeup of this governing body is very interesting, as it features almost the entire party leadership alongside veterans from the most diverse political

9 'Sprawozdanie z działalności Zarządu Głównego ZBoWiD w 1966 roku', AZGZKRPIBWP 3, 29, p. 35.

10 Za Wolność i Lud 10 (1959), p. 40. 
backgrounds. A[rtur] S[tarewicz] explains that this diversity reflects a desire not to turn ZBoWiD into a politically monolithic organization. Well, we shall see. ${ }^{11}$

The change of chairman at the Third ZBoWiD Congress was part of the political tumult of the 1960s, which culminated in the anti-Semitic campaign of 196768 and the youth rebellions of $1968 .{ }^{12}$ The departure of Janusz Zarzycki from ZBoWiD in 1964 was the result of an ideological conflict between the liberal and nationalist wings within the communist party. From this time, the organization was heavily influenced by Mieczysław Moczar, who by the end of the year had taken up the position of Minister of Internal Affairs. It was at this time that the Ministry of Internal Affairs became the venue for deeds that would return on a larger scale at the end of the decade: questioning the loyalty of officials with Jewish backgrounds, labelling them as guilty of the crimes of Stalinism, removing them from their positions, and more broadly manipulating anti-Semitic attitudes among the population as a means of legitimizing the regime. ${ }^{13} \mathrm{As}$ ZBoWiD chairman, Mieczysław Moczar differed from his predecessor Janusz Zarzycki in his style of leadership. He loudly proclaimed that blood spilled in the name of Poland must not be divided; in this way, he expressed his acceptance of Home Army circles. He travelled throughout Poland, meeting veterans and spending time with them in informal settings, such as around the campfire with barbecued sausages and vodka. In Warsaw, he regularly received the representatives of various veterans' groups. In his public performances, he told lively stories about the past that highlighted the heroism of Poles during the German occupation. ${ }^{14}$

Precisely because of Moczar's profile, the year 1964 is an important juncture in the history of the formation of a consolidated veterans' movement in postwar Poland. The political scene was filled by new people; the majority were individuals who belonged to what public opinion would come to identify as the

11 Mieczysław F. Rakowski, Dzienniki polityczne. 1963-1966, Warszawa 1999, p. 207. Stanisław Wroński (1916-2003) was a communist partisan and a historian. He rose to prominence in the 1960s as one of the ideologists of the party's nationalist wing. In 1972 he replaced Moczar as the chairman of ZBoWiD. Similarly, Mieczysław Róg-Świostek (1919-2000) was a former AL partisan, party functionary and journalist who earned his visibility in the 1960 s thanks to his ties to Moczar as well as his popularity in the countryside. He was editor-in-chief of the journal Chtopska Droga ('The Peasants' Way'). In contrast to the former two, Artur Starewicz (1917-2014), a close propaganda advisor to Władysław Gomułka, was a supporter of liberalization. Alongside Mieczysław F. Rakowski, he was one of the opponents of national communism.

12 E.g. Jerzy Eisler, Polski rok 1968, Warszawa 2006; Krzysztof Persak, Sprawa Henryka Hollanda, Warszawa 2006, pp. 26-67.

13 Stola, Kampania antysyjonistyczna, p. 19.

14 Lesiakowski, Moczar, pp. $277 \mathrm{f}$. 
ruling party's 'Partisan faction' ${ }^{15}$ The phenomenon of the Partisans was a hot topic of debate among political observers during communist times. Jan NowakJeziorański, the chief of Polish broadcasting at Radio Free Europe, described it as a mafia with 'all of the sociological traits of the American gang; ${ }^{16}$ and the aforementioned Mieczysław Rakowski wrote of a 'red-black' formation, meaning fascist tendencies in a communist party. Historians tend to consider the Partisans as the ideological heirs of the so-called 'Natolin Group', the representatives of a faction within the PZPR that vocally opposed the liberalization of the political system in 1956, and a group that was characterized above all by its anti-Semitic practices. ${ }^{17}$ Sociologists have suggested that the Partisans' supporters were often 'frustrated civil servants' who had little or no prospect of advancing up the social hierarchy. ${ }^{18}$ The Partisans attacked their opponents and thereby opened up career opportunities for individuals in their thirties and forties. The influence of the Partisans rose in parallel with, and in response to, the growing use of patriotic symbols by the party and governmental elite, and simultaneously contributed to the emergence of an informal and clientelistic structure of power.

The very term 'Partisans' was invented by Ernest Halperin, a correspondent for Neue Züricher Zeitung, and popularized firstly by Arthur Olsen of The New York Times and later by Radio Free Europe, which in the years 1962-71 broadcast a series of programmes dedicated to the 'unveiling' (dekonspiracja) of the faction, as Jan Nowak-Jeziorański put it in his memoirs. ${ }^{19}$ According to the popular narrative, the key event that pointed to the existence of a closely knit 'group' was the publication of a collection of interviews under the title Ludzie, fakty, refleksje ('People, Facts, Reflection'), containing the memoirs of commanders of the People's Army. The book, whose publication was initiated by Walery Namiotkiewicz, Gomułka's secretary, was printed by the Ministry of Defence on the eve of the public celebrations of the twentieth anniversary of the founding of the PPR (1961). ${ }^{20}$ Importantly, the book did not feature the recollections of

15 In order to retain clarity, the political grouping of the 1960 s will be referred to as the 'Partisans', with a capital 'P'. In contrast, the non-capitalized word 'partisans' refers to resistance fighters in general. [Translator's note.]

16 Jan Nowak-Jeziorański, Polska z oddali. Wojna w eterze - wspomnienia, vol. 2: 19561976, London 1988, p. 233.

17 Persak, p. 61.

18 Bauman, 'O frustracji i kuglarzach', Kultura 1968, no 12.

19 Jan Nowak-Jeziorański, Polska wczoraj, dziś i jutro, Warszawa 1999, p. 67; idem, Polska $z$ oddali, p. 229f; Persak, p. 64; Lesiakowski, Moczar, p. 219. Mikołaj S. Kunicki, Between the Brown and the Red: Nationalism, Catholicism, and Communism in Twentieth Century Poland: The Politics of Bolestaw Piasecki, Athens 2012, p. 222.

20 Mieczysław Moczar, Grzegorz Korczyński, Hilary Chełchowski, Marian Janic, Franciszek Szlachcic, Mieczysław Róg-Świostek, Tadeusz Pietrzak, Zygmunt Duszyński, Józef Sęk- 
key individuals from the wartime party leadership, but it did contain interviews with figures in important positions in the state power structures at the time of publication, and people who were known to be close to Mieczysław Moczar. ${ }^{21}$

The publication of Ludzie, fakty, refleksje was followed by the appearance of Mieczysław Moczar's novel Barwy walki ('The Colours of Battle', 1962), a book which combines literary cliché with a cult of the communist partisan movement. Whilst it is not clear who the actual author was, ${ }^{22}$ this fictional account effectively fused political didacticism with literary devices, for example in its presentation of the model heroism of the patriotic 'forest brothers'. This genuinely popular book was also aggressively promoted by propaganda. By 1970 it had gone through eleven print runs, been translated into seven foreign languages and adapted for the cinema screen, and Moczar had collected several prizes. ${ }^{23}$

Opinions are divided on whether the Partisans existed as an autonomous and readily definable faction, or whether they were invented by commentators at the time in an attempt to succinctly capture a nebulous social phenomenon. However, no matter who identified with the group and whether or not they could boast a wartime past in the resistance movement, the Partisans did function as a group in the political language of the era. Mieczysław F. Rakowski made observations in his diary about people who had come to him and encouraged him to 'join the Partisans', or about a general who found himself 'out of favour' with the Partisans. ${ }^{24}$ Correspondingly, the phenomenon of Partisan culture was also a social fact that characterized the 1960s, and an important one for understanding the functioning of $\mathrm{ZBoWiD}$ at this time.

\section{'Only ZBoWiD can speak in the name of the Home Army tradition'}

'I don't know where Colonel Mieczysław Niedzielski ${ }^{25} \ldots$ is, or what he is doing. But from this rostrum, former Colonel 'Zenon', member of the People's Army command staff in [the Warsaw district of] Żoliborz, sends his soldierly

Małecki, Teodor Kufel, Aleksander Kokoszyn i Stanisław Wroński. Bohdan Rostropowicz, Walery Namiotkiewicz (eds), Ludzie, fakty, refleksje, Warszawa 1961.

21 More in: Eisler, p. 26, 27.

22 The book reads very well, which gave rise to allegations that it had been ghostwritten by a professional.

23 Lesiakowski, Moczar, p. 232.

24 Rakowski, Dzienniki polityczne. 1963-1966, p. 201.

25 Mieczysław R. Niedzielski (1897-1980) was a professional serviceman in the inter-war period; in the course of the war one of organizers of Home Army conspiracy in Warsaw 
greetings.' This rhetorical gesture by Zenon Kliszko, ${ }^{26}$ secretary of the PZPR Central Committee and a close collaborator of Władysław Gomułka, addressed to an émigré who had led the Home Army in Żoliborz during the Warsaw Uprising (1944), was an important sign of the regime's opening up to former soldiers of the Home Army. Kliszko's speech was delivered shortly after the Fourth Congress of the party on 31 July 1964, during the twentieth-anniversary commemorations of the Warsaw Uprising, co-organized by ZBoWiD. Fragments of the address were published in Za Wolność i Lud under the suggestive title 'Nothing Divides us any Longer' (Nas już nic nie dzieli). ${ }^{27}$

It is almost universally accepted that it was Mieczysław Moczar who opened the Union to non-communist armed organizations, thereby establishing the veterans' organization as an important social platform for his political activity. ${ }^{28}$ (Zenon Kliszko was speaking a month before Moczar was elected to the position of ZBoWiD chairman.) As shown in the previous chapter, however, the Union had been accepting former Home Army members under the chairmanship of Janusz Zarzycki. It seems that the key point of disagreement between Zarzycki and the Partisan faction was not the issue of whether or not to admit former Home Army soldiers into $\mathrm{ZBoWiD}$, but the degree to which ideological concessions should be made to the martyrdom of the AK. At the end of the 1950s and the beginning of the 1960s, the Home Army's martyr myths were still considered to be a form of nationalist deviation inimical to the pacifist line of Marxism. However, the Partisans were prepared to accept many of the associated ideas and to put them to use.

One of the important innovations that Moczar made as the chairman of ZBoWiD was that the organization began to make overtures to émigré communities in the West. The ZBoWiD leadership founded commissions for cooperation with Poles abroad, with the aim of setting up joint activities for the building of memorials, exchanges of historical documents, and verification of ranks and military honours. ${ }^{29}$ These gestures had an important propaganda dimension: they polemicized with negative opinions about ZBoWiD and the Gomułka regime more generally that

and a commander of Żoliborz district during the Warsaw Uprising; after the war in exile in the USA.

26 Zenon Kliszko (1908-1898) participated in the Warsaw Uprising, which had been often underlined by communist propaganda of this period.

27 Zenon Kliszko, “"Nas już nic nie dzieli”. Z przemówienia Zenona Kliszki w Warszawie na akademii z okazji XX rocznicy Powstania Warszawskiego', Za Wolność i Lud, 16 (1964), p. 3. See also idem, Powstanie warszawskie. Artykuly, przemówienia, wspomnienia, dokumenty, Warszawa 1964, p. 113, 114.

28 E.g. Lesiakowski, Moczar, pp. 277-288.

29 'Materiały sprawozdawcze z prac Zarządu Głównego i Komisji ZBoWiD za okres grudzień 1964-czerwiec 1965’, AZGZKRPiBWP 3, 49, p. 182. 
were disseminated by the Polish branch of Radio Free Europe and other émigré media outlets. Both sides of the conflict - diasporic and Poland-based circles considered themselves to be the exclusive representatives of the interests of the Home Army. One speaker at a session of the ZBoWiD Supreme Council in 1966, a former commander of the Home Army's sabotage division in Kielce region, emphasized that the image of the Home Army soldiers as described by Radio Free Europe - that of a soldier who is 'discriminated against, impoverished and terrified'- did not fit the reality of the 1960s:

[This image] does not correspond to the former AK soldier who is now a university dean, or a valued doctor, engineer, mechanic, excellent civil servant or manual worker, or the owner of a private workshop. It doesn't correspond to the former AK soldier who is now an active member of ZBoWiD and a patriot. Radio Free Europe tries to oppose the traditions of the Home Army to People's Poland. But in this country we have a right to the legacy of the Home Army. We are the overwhelming majority. Only ZBoWiD, this Union of veterans and no-one else, can speak in the name of the Home Army tradition. ${ }^{30}$

The twentieth anniversary of the end of the war provided an important pretext for $\mathrm{ZBoWiD}$ to conduct activities that were intended to prove that veterans living abroad supported socialist Poland. Despite efforts, however, these initiatives were largely unsuccessful: of 33 invitations sent abroad, only a handful were accepted. ${ }^{31}$ Contacts with veterans' groups in the diaspora did allow for the organization to expand the imagined, i.e. purely propagandistic, geographical limits of the veterans' movement. In 1965, a ZBoWiD delegation carried out talks with Polish veterans in the United Kingdom. ${ }^{32}$ A year later, ZBoWiD's publishing house issued a photograph of Zygmunt Berling (the former commander of the Polish Armed Forces in the East) and Marian Sołtysiak (a former Home Army partisan) laying memorial wreaths at the grave of General Władysław Sikorski at the Polish air force cemetery in Newark-upon-Trent, UK. ${ }^{33}$ The Union announced the unveiling in Warsaw of a memorial plaque at the symbolic grave for Polish soldiers of the Independent Parachute Brigade, which had been created in Scotland in 1941 in order to drop into occupied Poland. ${ }^{34}$ According to the official report, this event

30 'Stenogram z posiedzenia Rady Naczelnej ZBoWiD, 15 lutego 1966. Przemówienie Mariana Sołtysiaka', AZGZKRPiBWP 3, 22, p. 128, 129.

31 'Sprawozdanie z działalności Zarządu Głównego ZBoWiD w 1966 roku', AZGZKRPiBWP 3,29 , p. 43.

32 Their major organization was the Polish Ex-Combatants' Association in Great Britain. See e.g. Rafał Habielski, Życie społeczne i kulturalne emigracji, Warszawa 1999.

33 O działalności i aktualnych zadaniach ZBoWiD. Posiedzenie Rady Naczelnej ZBoWiD, Warszawa 1966, p. 46.

34 However, contrary to the hopes of the soldiers, the unit was used by the British Army in the West, at the Battle of Arnhem (1944), where it suffered severe casualties. 
was attended by around 200 'parachutists and elite paratroopers [Cichociemni] from Poland and abroad. ${ }^{35}$ Union officials also boasted of the arrival in Poland, albeit for a short visit, of Colonel Jan Falkowski, a commanding officer of RAF no. 303 Polish Fighter Squadron, which participated in the Battle of Britain. ${ }^{36}$

Another point of disagreement between the two ZBoWiD chairmen was, in the terminology of the day, the 'mass-ness [masowość ]' of the organization. Towards the end of the 1950s, Janusz Zarzycki explicitly objected to what he saw as the excessive numerical expansion of the $\mathrm{ZBoWiD}$ rank and file. He argued repeatedly that the opening up of the Union would lead to an influx of false veterans. Under Moczar, on the other hand, constant expansion was a stated priority of the Main Directorate, discussed at many meetings of the central leadership and passed on with clear instructions to local branches. In his speeches, Mieczysław Moczar pointed to the examples of France and Yugoslavia, emphasizing that Poland should aim to catch up with these countries in terms of the number of registered veterans. ${ }^{37}$ As a result, former members of the civilian resistance movement were invited to join ZBoWiD. A few months after the Third Congress, Henryk Matysiak stated during a plenary session of the Warsaw regional directorate: 'We are thinking of the hundreds of mothers, of people who organized liaison points, of doctors and other people who cannot prove their eligibility via membership in a concrete veterans' group. ${ }^{38}$

The number of people joining ZBoWiD grew steadily from the moment Moczar took up the role of Union chairman (see Table 5.1). The 'massification' (umasowianie) of the organization also affected the number of local branches and groups. The local chapters, which had effectively become bureaucratic fictions in the Stalinist era, gained a newfound significance in the 1960s, as they were the basic contact points for people trying to gain material assistance through ZBoWiD. Meanwhile, for the organization's leadership, the local structures were an instrument for control, thanks to measures taken through the decade to improve the efficiency of the bureaucratic-administrative apparatus. Local branches (oddziaty), formed at the county or city district level, had stabilized during Zarzycki's chairmanship. Under Mieczysław Moczar, however, the group (koło) was promoted as the basic organizational unit; by 1967, ZBoWiD had over 3,000 groups of this kind.

35 'Sprawozdanie z działalności Zarządu Głównego ZBoWiD w okresie od III Kongresu Związku do 31 grudnia 1965', ibid., 3, 29, p. 191.

36 Ibid.

37 Mieczysław Moczar, 'Jedność działania' in O działalności i aktualnych zadaniach ZBoWiD. Posiedzenie Rady Naczelnej ZBoWiD, Warszawa 1966, p. 14, 15.

38 'Stenogram z plenarnego posiedzenia zarządu okręgu warszawskiego ZBoWiD', 28 March 1965, AAN, ZG ZBoWiD, 1, 387, p. 288. 
Table 5.1 Number of organization units and the total membership of ZBoWiD, 1959-69

\begin{tabular}{|l|c|c|c|c|c|c|c|c|c|c|c|c|}
\hline & 1956 & 1959 & 1960 & 1961 & 1962 & 1963 & 1964 & 1965 & 1966 & 1967 & 1968 & 1969 \\
\hline $\begin{array}{l}\text { Branches } \\
\text { (Oddziały) }\end{array}$ & n.d. & 357 & 359 & 363 & n.d. & 371 & 371 & 372 & 372 & 372 & n.d. & n.d. \\
\hline $\begin{array}{l}\text { Groups } \\
\text { (Koła) }\end{array}$ & n.d. & 1344 & 1424 & 1628 & n.d. & 2070 & 2219 & 2437 & 2773 & 3144 & n.d. & n.d. \\
\hline $\begin{array}{l}\text { Members } \\
\text { (thousands) }\end{array}$ & ca50 & $c a 150$ & 159 & 170 & 155 & 160 & 170.5 & 188 & 205 & 222 & 248 & 292 \\
\hline
\end{tabular}

Sources: 'Materiał informacyjny z działalności Zarządu Głównego ZBoWiD za okres wrzesień 1959 - wrzesień 1960', AZGZKRPiBWP 3, 39; 'Informacja z działalności Zarządu Głównego ZBoWiD za okres wrzesień 1959 - kwiecień 1961', AZGZKRPiBWP 3, 38, p. 21; Sprawozdanie z działalności w latach 1960-1964, Warszawa 1964, p. 31; 'Materiały sprawozdawcze z prac Zarządu Głównego i Komisji ZBoWiD za okres grudzień 1964 czerwiec 1965', AZGZKRPiBWP 3, 49; 'Informacja sprawozdawcza z działalności Zarządu Głównego ZBoWiD w 1967 roku', AZGZKRPiBWP 3, 54, p. 3; Roczniki Statystyczne (19611970), Warszawa 1962-71.

It is not clear, however, who exactly joined ZBoWiD. With the emphasis being placed on the unity of the 'family of veterans' rather than any natural divisions, membership statistics differentiated by memory group (partisans, prisoners, etc.) were compiled irregularly. Nonetheless, according to classified information held by the Ministry of Internal Affairs, in 1965 ZBoWiD had more than 60,000 former Home Army partisans among its ranks. ${ }^{39}$ Records kept about local directorates are another source of information, as they provide an indication of the wartime past of their members. These are not representative for ZBoWID as a whole, but they do supply a reliable reflection of the preferences of the Union leadership: whom they wanted to see (or tolerated) in positions of responsibility as the representatives of local-level veterans' groups. A comparison of the compositions of county directorates in 1961/62 and 1968 shows that at both times, former soldiers (veterans of the 1939 defence war, the Polish Armed Forces in the West, and the pro-communist Polish Armed Forces in the East) were the most numerous group among local officials, followed by members of the resistance movement, with former prisoners in third place (see Table 5.2). The relatively high number of regular soldiers in county directorates suggests that the idea of Moczar's ZBoWiD being dominated by partisans requires re-examination. It is also conceivable that active soldiers were delegated to $\mathrm{ZBoWiD}$ in order to help monitor and control the organization.

39 Krzysztof Lesiakowski, '”Partyzanci” wobec dziejów Polski w czasie II wojny światowej’, in Sławomir M. Nowinowski, Jan Pomorski and Rafał Stobiecki (eds), Pamięć i polityka historyczna. Doświadczenia Polski i jej sq̨siadów, Łódź 2008. The author cites a note in the personal file of Marian Janic (AAN, 2418/3, p. 302). 
Table 5.2 Composition of county directorates (1961/62 and 1968)

\begin{tabular}{|l|c|c|c|c|}
\hline \multirow{2}{*}{$\begin{array}{l}\text { Composition of } \\
\text { directorate }\end{array}$} & \multicolumn{2}{|c|}{$1961 / 62$} & \multicolumn{2}{c|}{1968} \\
\cline { 2 - 5 } & $\mathrm{N}$ & $\%$ & $\mathrm{~N}$ & $\%$ \\
\hline Number of members of county directorates & 5674 & 100 & 8947 & 100 \\
\hline New individuals & 2523 & 44 & 3145 & 35 \\
\hline Pensioners & 823 & 14 & 2000 & 22 \\
\hline Women & 254 & 5 & 449 & 5 \\
\hline Professional army officers & 226 & 4 & 447 & 4 \\
\hline Veterans of the Revolutionary Struggles 1905 & 101 & 2 & 72 & $>1$ \\
\hline Silesia and Wielkopolska Uprisings & 690 & 12 & 759 & 8 \\
\hline Polish activists in pre-war Germany & 13 & $>1$ & 32 & $>1$ \\
\hline Dąbrowski battalion and brigade & 44 & 1 & 21 & $>1$ \\
\hline Prisoners of Sanacja regime & 97 & 2 & 170 & 2 \\
\hline Soldiers of the 1939 Polish-German war & 501 & 9 & \multirow{2}{*}{3196} & 36 \\
\hline Polish Armed Forces in the East and West & 1417 & 25 & & 32 \\
\hline Resistance movement & 1607 & 28 & 2906 & 13 \\
\hline Concentration camp prisoners & 989 & 17 & 1148 & 7 \\
\hline Communist power apparatus of late 1940s & 215 & 4 & 643 & 2 \\
\hline
\end{tabular}

Source: 'Sprawozdanie z przeprowadzonej akcji wyborczej w zarządach powiatowych ZBoWiD, 1961-1962', AZGZKRPiBWP 3, 42; 'Zbiorcze sprawozdania statystyczne z przeprowadzonej akcji sprawozdawczo-wyborczej w oddziałach powiatowych ZBoWiD w 1968 roku, Warszawa, 20 lutego 1969', AAN, ZBoWiD, Zarząd Główny, 1, 19.

Declarations made by newly elected officials of county directorates are another useful source of information. For the years 1961/62 and 1965/66, these declarations contain information that was deliberately omitted from official data compilations, significantly including personal histories of individuals who belonged to underground organizations during the war. As this form of data requires a great deal of time-consuming processing work, Table 5.3 compiles information for two administrative regions only: Warsaw and Lublin voivodeships. It includes the chairmen, deputy chairmen, secretaries and treasurers of county directorates and the chairmen, deputy chairmen and secretaries of revision commissions. Wherever the individual has given two or more 'titles' of membership (e.g. participation in both the Home Army and the Second Army of the Polish Armed Forces), all entries are counted. Of course, it cannot be assumed that all declarations were fully truthful; however they do provide a good indication of the images that Union officials wanted to portray of themselves, as well as the limits of freedom of expression in matters concerning individual pasts. 
Two important findings result from this data. Firstly, that a significant proportion of individuals openly admitted to previous membership in the Home Army: in the years 1961/62, Home Army partisans made up 25 percent of the county directorates in Lublin voivodeship and 36 percent in Warsaw voivodeship; for 1965/66, these figures are 23 percent and 26 percent respectively. Secondly, that the number of Home Army soldiers in county directorates was proportionally lower in 1965/66 than in 1961/62; in other words, the Home Army had a greater representation in the local power structures of ZBoWiD under Janusz Zarzycki than under Mieczysław Moczar. This fact, once again, casts doubt on the idea promoted by Moczar's associates that ZBoWiD became an organization open to non-communist veterans under the new chairman's watch.

Table 5.3 Composition of county directorates according to group, Lublin and Warsaw voivodeships (1961/62 and 1965/66)

\begin{tabular}{|l|c|c|c|c|c|c|c|c|}
\hline & \multicolumn{4}{|c|}{ Lublin } & \multicolumn{4}{c|}{ Warsaw } \\
\hline & $1961 / 62$ & \multicolumn{1}{|c|}{$1965 / 66$} & \multicolumn{2}{|c|}{$1961 / 62$} & \multicolumn{2}{|c|}{$1965 / 66$} \\
\hline & $\mathrm{N}$ & $\%$ & $\mathrm{~N}$ & $\%$ & $\mathrm{~N}$ & $\%$ & $\mathrm{~N}$ & $\%$ \\
\hline $\begin{array}{l}{[\text { Resistance movement }-} \\
\text { combined }]\end{array}$ & {$[108]$} & {$[63]$} & {$[106]$} & {$[63]$} & {$[151]$} & {$[60]$} & {$[150]$} & {$[48]^{*}$} \\
\hline Home Army & 42 & 25 & 38 & 23 & 90 & 36 & 82 & 26 \\
\hline People's Army & 35 & 20 & 44 & 26 & 40 & 16 & 36 & 12 \\
\hline Peasants' Battalions & 31 & 18 & 24 & 14 & 10 & 4 & 13 & 4 \\
\hline $\begin{array}{l}\text { Resistance movement }- \\
\text { other }\end{array}$ & 0 & 0 & 0 & 0 & 11 & 4 & 19 & 6 \\
\hline Prisoners & 23 & 13 & 18 & 11 & 38 & 15 & 42 & 14 \\
\hline $\begin{array}{l}{[\text { Regular soldiers- }} \\
\text { combined }]\end{array}$ & {$[27]$} & {$[16]$} & 30 & {$[18]$} & {$[41]$} & {$[16]$} & {$[77]$} & {$[25]$} \\
\hline $\begin{array}{l}\text { Polish Armed Forces in } \\
\text { the East }\end{array}$ & 25 & 15 & 30 & 18 & 32 & 13 & 63 & 20 \\
\hline $\begin{array}{l}\text { Polish Armed Forces in } \\
\text { the West }\end{array}$ & 0 & 0 & 0 & 0 & 0 & 0 & 3 & 1 \\
\hline 1939 Polish-German war & 2 & 1 & 0 & 0 & 9 & 3 & 11 & 4 \\
\hline Other and No data & 14 & 8 & 13 & 8 & 22 & 9 & 39 & 13 \\
\hline Total & $\mathbf{1 7 2}$ & $\mathbf{1 0 0}$ & $\mathbf{1 6 7}$ & $\mathbf{1 0 0}$ & $\mathbf{2 5 2}$ & $\mathbf{1 0 0}$ & $\mathbf{3 0 8}$ & $\mathbf{1 0 0}$ \\
\hline
\end{tabular}

Sources: 'Arkusze ewidencyjne członków zarządów oddziałów 1961/1962' AAN, ZBoWiD ZG, 1, 13 and 1, 14, pp. 296-333 and 258-317; 'Arkusze ewidencyjne członków zarządów oddziałów 1965/1966’, AAN, ZBoWiD ZG, 1, 16, pp. 1-42, 315-389.

* The relatively low number of people admitting to wartime participation in armed resistance in 1965/66 in Warsaw voivodeship is most likely connected to the large number of declarations in which no data is available. 
So, did Mieczysław Moczar make ZBoWiD more accessible to people with a Home Army past? This question has no straight answer. Former Home Army partisans had joined the Union in previous years, and their representation in local directorates may have been higher during the chairmanship of Zarzycki. Nevertheless, Moczar presided over the formation of a more permissive climate in which a variety of armed formations gained wider acceptance, a fact that resonated with the rhetoric of national unity propounded by the Partisan faction.

\section{Partisan culture}

A popular anecdote of the 1960s: a personal notice in a Warsaw newspaper reads, 'Will exchange participation in victory at Lenino for two weeks of partisan activity in Lublin region. ${ }^{40}$ As the myth of the resistance movement rose to prominence, the roles of the Polish Armed Forces in the East and the Red Army in the liberation of Poland were devalued. Furthermore, wartime narratives emphasized the commonality of the fates of all Poles with increasing regularity. The party's ideological emphasis on the Polish nation and the ubiquitous popular interest in the Second World War contributed to a highly conducive atmosphere for the proliferation of military myths. ${ }^{41}$ From the middle of the 1960 s, representations of the war that foregrounded the themes of military bravado and bold adventure,

40 Nowak-Jeziorański, Polska z oddali, p. 231. On the Battle of Lenino, see footnote 39 in Chapter 2.

41 The war was one of the most important themes for Polish literature in the late 1950s and 1960s: some of the most popular books published in this period include works by Andrzej Brycht, Roman Bratny, Melchior Wańkowicz and Wojciech Żukrowski. In 1957, the publishing house of the Ministry of National Defence founded the popular Żótty tygrys ('Yellow Tiger') book series, a large collection of narratives about the Second World War, often written in the simple style of an adventure story. A number of significant, and stylistically diverse, films were also produced and had a profound effect on the popular imagination of the war, such as: the existential dramas of Andrzej Wajda, including Kanat (1957), Popiót $i$ diament ('Ashes and Diamonds', 1958) and Lotna (1959); Andrzej Munk's Eroica (1957); Sylwester Chęciński's Agnieszka '46 (1964); comedies by Stanisław Lenartowicz, such as Giuseppe w Warszawie ('Giuseppe in Warsaw', 1964), and by Tadeusz Chmielewski, such as Jak rozpętatem druga wojnę światowa ('How I Unleashed the Second World War', 1969); and the celebrated television series Stawka większa niz zycie ('More than Life at Stake', 1967-68), directed by Jerzy Morgenstern, and Czterej pancerni i pies ('Four Tankmen and a Dog', 1966-70), by Konrad Nałęcki and Stanisław Czekalski. Also of note is the fact that the cinematic adaptation of Henryk Sienkiewicz's novel Krzyżacy ('Knights of the Teutonic Order', 1960), directed by Aleksander Ford, was released on 1 September 1960 , the anniversary of the German invasion of Poland. The story narrates the defeat of the Teutonic Order by Polish-Lithuanian forces at the Battle of Grunwald (1410). 
rather than individual suffering and trauma, were met with growing approbation by politicians. The conventions of this genre were most fully expounded by the novelist and screenwriter Zbigniew Załuski, a frequent guest at ZBoWiD meetings, in his famous book Siedem polskich grzechów głównych ('The Polish Seven Deadly Sins'), which was first published in 1963 and which the author conceived as a defence of Polish history against the 'falsifiers' who were tarnishing the legacy of the war. ${ }^{42}$ Załuski rejected 'cheap and tearful humanitarianism' and 'pacifism and superficial anti-militarism', arguing that they usually accompany 'philistine pusillanimity and egoism'. On the one hand, he cited the classics of MarxismLeninism; on the other, he rejected the entire pacifist tradition of Marxism and its critique of war as an instrument of imperialism. ${ }^{43}$

Amidst this cultural atmosphere, ZBoWiD sought to collaborate with writers and filmmakers. Union officials emphasized the importance of influencing public opinion by means of new technologies, especially television. ${ }^{44} \mathrm{~A}$ report from the mid-1960s gleefully highlights the fact that 'a group of intellectuals and creative individuals for whom ZBoWiD's activity is significant, interesting and always topical has emerged and is continually growing.' At the same time, the report criticizes work that fails to conform to the hero myth. ${ }^{45}$

In 1964, Wilhelm Mach was awarded a state prize for his novella Agnieszka, córka Kolumba ('Agnieszka, Daughter of Columbus'), which describes the difficulties faced by soldiers in trying to return to civilian life. The story was immediately adapted for the cinema by Sylwester Chęciński. Whereas the film does contribute to the myth of the Polishness of the formerly German western territories, it was nonetheless criticized heavily by partisan circles. In 1966 at a session of the ZBoWiD Supreme Council, Załuski condemned both Agnieszka '46 and Pierwszy dzień wolności ('First Day of Freedom', 1964) by Aleksander Ford for failing to feature heroic plot lines. Tadeusz Hołuj disagreed with Załuski, defending the deceased Mach and other existentialist authors: 'we cannot accept such a principle whereby literature or film cannot depict, say, a soldier raping a girl, or a soldier drinking vodka'; but his position was isolated. ${ }^{46}$

Debates about culture were conditioned by an important social fact: a generation of people who had not experienced the war was entering adulthood. In previous years, the verisimilitude of any given representation of the war was not

42 Zbigniew Załuski, Siedem polskich grzechów głównych, Warszawa 1963.

43 Cited in: Maria Janion, Wojna i forma. Eseje o wojnie, Warszawa 1998, p. 38.

44 'Materiały sprawozdawcze z prac Zarządu Głównego i Komisji ZBoWiD za okres grudzień 1964 - czerwiec 1965', AZGZKRPiBWP 3, 49.

45 'Sprawozdanie z działalności Zarządu Głównego ZBoWiD w okresie od III Kongresu Związku do 31 grudnia 1965', AZGZKRPiBWP 3, 29, p. 181.

46 Ibid., p. 122. 
a crucial issue for people who had actually lived through the war, as they could evaluate narratives in relation to their own experiences and memories. Young people, meanwhile, were not necessarily well-versed in the language of state propaganda concerning the war, and often were not particularly interested in the theme. Veterans understood this well, and they began a battle for the hearts and minds of the younger generation. It was argued that influencing the Polish youth is equally as important as counteracting West German propaganda. ${ }^{47}$ School visits by veterans and former political prisoners became increasingly more frequent, and ZBoWiD introduced initiatives for the transmittance of memory models: youth camps, scouts' expeditions, group excursions, and outings on foot and by bicycle that retraced the histories of partisan detachments and regular army units. ${ }^{48}$ Youth education in war memory changed in line with political transformations, and its evolution reflected a gradual trend towards a strictly national focus.

The Partisans explained the need to engage artists and writers in commemorative activities, and also to suppress works about the war that were more contemplative or satirical, precisely in terms of protecting the younger generation. Załuski said in 1966 at a session of the Supreme Council: 'It seems to me that there is an obstruction, a wedge ... between the youth and us, our achievements. The attitudes of the creative circles in Poland are that obstruction. ${ }^{49}$ The political conservatism of Partisan culture reached its apogee in the late 1960s. An article in Za Wolność $i$ Lud entitled 'We will not endorse that' (Tego rachunku nie podpiszemy), by Jan Srebrzyński, acted as the guiding text for ZBoWiD. The author described the symptoms of 'national nihilism', and criticized the devaluation of positive heroes in literature and cinema. He echoed previous denunciations of the films Popiót $i$ diament, Eroica, Kanat, ${ }^{50}$ and even the comedy Zezowate szczesście ('Crosseyed Luck', dir. Andrzej Munk, 1960), arguing that 'the description of real life, the universal truths of raw historical fact are replaced in these films by arbitrary constructions, manipulative tricks, subjective sufferings and marginal events.' The harshest words were reserved for the documentary Bytem kapo ('I was a Kapo', dir. Tadeusz Jaworski, 1963), the tragicomedy Don Gabriel (dir. Ewa and Czesław Petelski, 1966) and the dramas Agnieszka '46 and Dluga noc ('The Long Night', dir. Janusz Nasfeter, 1967). Srebrzyński wrote of Dluga noc: 'There is not a single German, no shots are fired, and no-one dies ... There is one Pole who offers a helping hand to a Jew. Polish society, driven by the most repugnant

47 'Stenogram z posiedzenia Rady Naczelnej ZBoWiD', 16 September 1963, AZGZKZRPiBWP 3, 19, p. 107 b.

48 See e.g.: Biuletyn Głównej Komisji Współpracy z Młodzieżą ZBoWiD 1967, no 1, 2.

49 'Stenogram z posiedzenia Rady Naczelnej ZBoWiD', 15 February 1966, AZGZKRPiBWP 3, 22, p. 90 .

50 See footnote 41 of this Chapter. 
concerns, helps the Germans carry out genocide; and a sentimental girl is torn by a moral conflict in her helpless despair. ${ }^{, 51}$ The author protested against these films in the name of public opinion, arguing that the creators were deliberately attacking patriotic feeling; he demanded that the artists' obstinacy be punished.

Similar statements were made at ZBoWiD meetings. An official ZBoWiD declaration published in May 1968 stated that a 'harmful phenomenon' had existed for years, whereby literature, film and theatrical drama had 'smuggled' ideas that were 'foreign to the spirit of the Polish people, anti-Polish and antisocialist.' According to the declaration, this state of affairs had resulted from the presence in cultural institutions of people who were 'hostile to socialism and to People's Poland.' Benefitting from their privileged status, they 'produced works whose contents were insulting to the Polish people, sometimes with a camouflaged message, but frequently overtly.' These people had treated 'the exhortations of ZBoWiD' to reinstate patriotism and a sense of duty to the country as a 'sign of provincial obsession with Polishness. ${ }^{52}$ This leads to another pattern of the late 1960s: anti-Semitism as a significant feature of public discourse.

\section{Rival Martyrologies}

\section{Wartime martyrdom}

The 1960s were a time not only for the transformation of hero myths; the period also brought changes to the idea of national victimhood. This trend was the result of increasingly complicated international relations between Poland, West Germany and Israel, and the conflict of the PZPR with the Catholic Church. In 1967, after the Six-Day War in the Middle East, the USSR and other countries of the communist bloc who backed Arab countries (with the exception of Romania), severed diplomatic relations with Israel and opened another chapter of Cold War. In Poland of 1967-1968, the anti-Israeli (and anti-USA) propaganda was intertwined with the anti-Semitic attitudes within the party that resulted in the forced emigration of the remnants of Polish Jews. ${ }^{53}$ Additionally, some motifs of this propaganda had also to do with the Polish-German relations, and these in turn were affected by earlier events, started by a letter sent by the Polish bishops to their German counterparts (1965), in which they expressed forgiveness for

51 Jan Srebrzyński, 'Tego rachunku nie podpiszemy', Za Wolność i Lud, 4 (1968), p. 5.

52 O zadaniach Zwiąku Bojowników o Wolność i Demokrację w okresie poprzedzającym IV Krajowy Kongres, Warszawa, May 1968, p. 13, 14.

53 Ca 13,000 by 1971. Cf. Dariusz Stola, 'The "Anti-Zionist" Campaign in Poland', n.d. p. 6. http://web.ceu.hu/jewishstudies/pdf/02_stola.pdf. (accessed 1 July 2015). 
the crimes committed by Germans during the Second World War and asked for forgiveness for the acts of revenge carried out by Poles after the war. ${ }^{54}$ Until that very moment, the expulsion of Germans from Poland in the late 1940s had been a taboo topic in public discourse. This letter, as well as the independent initiative shown by the Catholic Church in Poland, provoked anger among the highest party leadership, who were not prepared to dampen their anti-German rhetoric in view of the FRG's continued refusal to recognize the Oder-Neisse border. The party and other organizations, including ZBoWiD, argued that the Poles have nothing for which to ask forgiveness of the Germans, and moreover, are not about to pardon the extermination of their own people. The dominant message in the politics of memory at this time therefore consisted in the myth of innocent victimhood: innocent because Poles could not possibly have committed crimes comparable to those of the Germans; they had fought and died exclusively in defence of a just cause and moral values. The conflict was heightened in 1966 during the millennial celebrations of Polish statehood, when the Catholic Church was commemorating the baptism of the country in $966 .^{55}$ This was the time when both sides of conflict used the myth of Polish martyrdom, and some of its motifs reappeared in the following years.

From the point of view of national martyrdom, former German concentration camps were the most important sites of memory, as they had been in the early 1950s. By this time, however, museum infrastructure had improved, an increasing number of sites were adorned with monuments and museums, and the camps were no longer mere symbols that figured in accounts of the war but physical tourist destinations attracting large numbers of visitors. The wartime suffering of civilians gained an ever increasing significance. A cult of sites of execution developed. The martyrdom of the village, towns and cities and even entire regions was emphasized, such as Zamość region in Eastern Poland, from which the Polish population was deported to make way for German settlers. In addition to commemorating the resistance movement, ZBoWiD organized innumerable exhibitions, seminars and other events that bore characteristic titles: 'The Crimes of Hitlerism in Poland', 'Never Again', 'Women and Children of Auschwitz', 'Crimes and Atrocities of the Hitlerites in Gdańsk Pomerania', 'Polish Women in Ravensbrück', 'The Lands of Białystok Accuse', 'Kielce Region Accuses', 'We Accuse - Hitlerite Crimes in Pomerania', 'On Hitlerite Crimes', 'The Children of Zamość Region Accuse', etc.

54 See for instance Karolina Wigura, 'Alternative Historical Narrative: "Polish Bishops' Appeal to Their German Colleagues" of 18 November 1965', East European Politics \& Societies 3, 27 (2013), pp. 400-412.

55 See e.g. Bartłomiej Noszczak, Sacrum czy profanum? Spór o istotę obchodów Milenium polskiego, Warszawa 2002. 


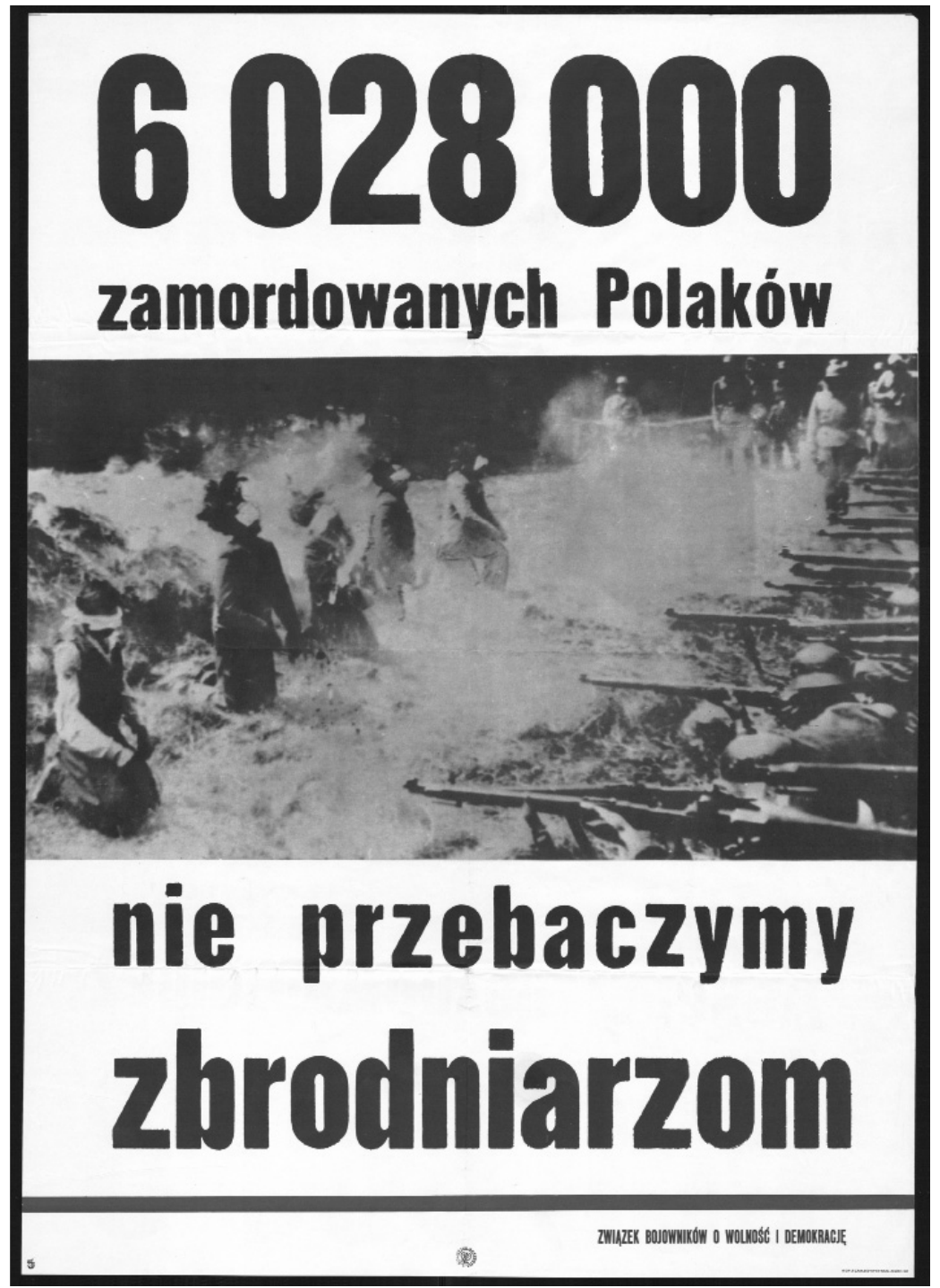

5.2 Typical propaganda motif spread by ZBoWiD during the millennial celebration of the Polish statehood: the caption runs: '6,028,000 murdered Poles. Murderers shall not be forgiven.' The number is somewhat overestimated and the formulation does not indicate that it contains also Jewish victims. The vengeful caption epitomizes the reaction of the party to the pastoral letter of Polish bishops to German bishops (November 1965), where they used the phrase: 'We forgive and ask for forgiveness.' National Library of Poland. 
The introduction to a book entitled Przewodnik po upamiętnionych miejscach walk i męczeństwa lat wojny 1939-1945 ('A Guide to Commemorated Sites of Battle and Martyrdom of the War Years, 1939-1945') supplies a model of the kind of narrative that was reproduced in local variants throughout the country:

During the Second World War, it was Poland which, of all of the states involved in the fighting, suffered the greatest number of losses in relation to the number of residents. Six million victims - men, women and children - were tortured and murdered by Hitlerism, gassed in the chambers and burned in crematoria at Auschwitz, Birkenau, Majdanek, Treblinka, Sobibór, Bełżec, Chełmno, the Seventh Fort in Poznań, Rogoźnica (Gross Rosen), Działdowo, Sztutowo (Stutthof) and dozens of other death camps, shot at sites of mass extermination in the streets of cities and towns. This is the price paid by the nation for its love of the country and of freedom. This is the monstrous record of brutal crimes. ${ }^{56}$

This quote shows that the wartime fate of Polish Jews was inscribed into the martyrdom narrative of the Polish nation as a whole. An individual reading this excerpt would receive no indication that, of the six million Polish victims, over three million died in circumstances that vastly differed from the rest. Before Janusz Zarzycki vacated his post as chairman of ZBoWiD in the mid-1960s, the lack of emphasis on the Jewish Holocaust can be explained by the reluctance on the part of some communists to employ ethnicity as a category in public discourse. This unwillingness was the result of a number of factors, including an anxiety about racist views and anti-Semitism becoming widespread, as well as the dominance within ZBoWiD in the years 1956-64 of the idea of the unity of all types of victims and heroes. Efforts were therefore made to show the ghettos (the Warsaw Ghetto in particular) as just one category of site where the people fought and suffered. It was rarely admitted that Jews, unlike non-Jewish Poles, faced certain and immediate death in the camps, and mention was hardly ever made of the relations between Poles and Jews - the only references tended to be in relation to crimes against Jews carried out by anti-communist formations such as the NSZ, which were considered marginal. Thus, statements that could bring into question of the innocence of Polish victims or the supposed unity of Polish society under occupation were avoided.

The special commemorations on the twentieth anniversary of the Warsaw Ghetto Uprising in 1963 provided a test case for this unity of memory. The event was marked by a conference in the Palace of Culture and Science, rallies by the monument to the Heroes of the Ghetto, commemorative ceremonies at Treblinka and Auschwitz, publications and theatrical productions. Around 600 delegates

56 Janusz Wieczorek, 'Przedmowa', in Przewodnik po upamiętnionych miejscach walk i męczeństwa lat wojny 1939-1945, Warszawa 1964. Cited in: Traba, 'Symbole pamięci', p. 61 . 
from thirty countries participated..$^{57}$ Janusz Zarzycki warned against attempts to 'turn the struggle of the Warsaw Ghetto in the wrong direction, to separate ... the struggle of the Polish people from the Ghetto Uprising, for after all, this was just one fragment of the struggle of the Polish people. ${ }^{58}$

However, in the latter half of 1960s and especially in the years 1967-68, the accent of this narrative changed. Ethnicity became an explicit criterion and, ironically at the height of the anti-Semitic campaign, the wartime martyrdom of the Jews increasingly became a theme for discussion. The logic of the argument of this time can be summarized in three steps: (1) the Poles were the greatest victims of the war, (2) the Jews also suffered, but the Poles rescued them heroically, (3) now the Jews are accusing the Poles of wartime atrocities committed against them, thereby showing their ingratitude for Polish assistance, because they are in league with West Germany, Poland's greatest enemy.

\section{Anti-Semitism}

The political mechanism of the propaganda of the second half of the 1960s has been analysed by a number of scholars. ${ }^{59}$ Few would now dispute that the anti-Zionist slogans that entered public usage after the outbreak of the Six-Day War in the

57 'Informacja sprawozdawcza $\mathrm{z}$ działalności Zarządu Głównego ZBoWiD za okres październik 1962 - czerwiec 1963’, AZGZKRPiBWP 3, 46.

58 'Stenogram z posiedzenia Plenum ZG ZBoWiD, 29 października 1962', AZGZKRPiBWP 3,43 , p. 18 .

59 On anti-Semitism in the 1960s in Poland see for instance: Josef Banas, The Scapegoats, the Exodus of the Remnants of Polish Jewry, London 1979; Michał Chęciński, Poland, Communism, Nationalism, Anti-Semitism, New York 1982; Eisler, pp. 88-140; Anna Barbara Jarosz, 'Marzec w prasie', in Marcin Kula, Piotr Osęka and Marcin Zaremba (eds), Marzec 1968. Trzydzieści lat później, Warszawa: PWN, 1998, pp. 99-125; Beate Kosmala (ed.), Die Vertreibung der Juden aus Polen 1968. Antisemitismus und politisches Kalkül, Berlin 2000; Krystyna Kersten, Komunizm. Anatomia pótprawd, 1939-1968, Warszawa 1992, pp. 143-180; Piotr Osęka, Syjoniści, inspiratorzy, wichrzyciele. Obraz wroga w propagandzie marca 1968, Warszawa 1999; Piotr Osęka and Marcin Zaremba, 'Wojna po wojnie - czyli polskie reperkusje wojny sześciodniowej', in Polska 1944/451989. Studia i Materiaty, 4 (1999), pp. 205-239; Agnieszka Skalska, Obraz wroga $w$ antysemickich rysunkach prasowych marca '68, Warszawa 2007; Michael C. Steinlauf, Bondage to the Dead. Poland and the Memory of the Holocaust, Syracuse 1997, pp. 7588; Stola, Kampania antysyjonistyczna; Dariusz Stola, 'Antyżydowski nurt Marca 1968' in Konrad Rokicki and Sławomir Stępień (eds), Oblicza Marca 1968, Warszawa 2004, pp. 65-72; Bożena Szaynok, Z historia i Moskwa w tle. Polska a Izrael 1944-1968, Warszawa 2007, pp. 394-456; Feliks Tych, 'Kilka uwag o Marcu 1968' in Marcin Kula, Piotr Osęka and Marcin Zaremba, pp. 261-283. 
Middle East contained a thinly veiled anti-Semitism. According to Dariusz Stola, the strength of the propaganda of March 1968 was in its appeal for citizens to violate the party dictatorship: participants of the numerous meetings and rallies organized by the party and other state institutions were encouraged to voice their 'honest, open and critical statements.' They were permitted to express their displeasure and demand change, on condition that their complaints were expressed in terms that condemned the enemies of the system. Stola writes: 'After years of timid silence, Poles were allowed to criticize the corruption and arrogance of the bureaucrats. Not all of them, of course, only the Jewish ones; but nonetheless, they could finally publically discuss bribery, clientelism and nepotism in the state apparatus. ${ }^{60}$ Sociologists and historians have argued that a striving for the legitimization of the regime was the main motive behind the deployment of nationalist slogans. Nonetheless, the question still often repeated is: was the anti-Semitism of 1967-68 an artificial phenomenon that imposed a political language onto society with the aim to relate to the Israeli-Arab war, as well as to divert citizens' attention from reformist movements in the countries of the bloc, such as events in Prague ${ }^{61}$ or protests of Polish students in $1968^{62}$; or was an opposite mechanism at work, whereby the rhetoric of the authorities responded to public demands?

Different evaluations were offered at the time. Many foreign observers believed Polish anti-Semitism to be a socio-cultural fact ${ }^{63}$ However, the thesis of universal anti-Semitism among Poles was questioned by many Polish voices, including Polish Jews such as the now world-famous sociologist Zygmunt Bauman, who then, as an émigré from Poland, ascribed the anti-Semitic campaign to mid-level party activists.$^{64}$ Others noted the mobilizing potential of anti-Semitism. Another émigré intellectual, Konstanty A. Jeleński, called its relapse 'one of the most painful issues in our history'. He wrote in 1968:

It shocks me to see a photograph on the front page of Życie Literackie ['Literary Life', a newspaper] a photograph of a crowd of over 100,000 people rallying on Market Square in Kraków on 25 March, bearing hundreds of banners which all begin with the obsessive word 'Zionists' ... So the party can mobilize 100,000 Poles under the slogan of anti-Semitism. ${ }^{65}$

60 Stola, Antyżydowski nurt, p. 68.

61 See for instance, Günter Bischof, Stefan Karner and Peter Ruggenthaler (eds), The Prague Spring and the Warsaw Pact Invasion of Czechoslovakia in 1968, Plymouth 2010.

62 See for instance, Tom Junes, Student Politics in Communist Poland: Generations of Consent and Dissent, Lanham 2015, pp. 63-122.

63 E.g. Paul Lendvai, Anti-Semitism without Jews: Communist Eastern Europe, Garden City, NY 1971.

64 Zygmunt Bauman, 'O frustracji i kuglarzach', Kultura 12 (1968), p. 19.

65 Konstanty A. Jeleński, 'Hańba czy wstyd?', Kultura 1968, cited in: Marta Fik, Kultura polska po Jatcie. Kronika lat 1944-1981, London 1989, p. 441. 
The opening of the communist archives after 1989 has revealed that anti-Semitism was by no means marginal. Nationalistic brochures and flyers were distributed throughout Poland, and whilst these were mostly prepared by the Security Service, they did have their share of readers. Anti-Semitic statements were openly made in shops, public stairwells, factories, and in readers' letters to newspapers ${ }^{66} \mathrm{ZBoWiD}$ in the years 1967-68 was one of the most important institutions propagating antiSemitic comments. Za Wolność i Lud repeated ideas voiced in party newspapers such as Trybuna Ludu and Żolnierz Wolności, clamouring about the threat posed by Zionism. It is not clear from official records how many Jewish members of the Union were expelled from the organization, but fragmentary evidence shows that unrest among the grassroots was rife.

For instance, in April 1968 the Lublin-based newspaper Kurier Lubelski announced that the city directorate of ZBoWiD had removed five Jewish communists from its ranks: Grzegorz Wajskop, Marek Kuperman, Adam Drewień, Mojżesz Wajsbrot and Henryk Dorfman. ${ }^{67}$ In July of the same year, 62-year-old Marek Kuperman, a communist for the past forty years, who was physically disabled and had four school-age children, wrote a letter to Mieczysław Moczar. He asked for intervention, describing the events that had preceded his expulsion from the Union: in late June 1967, he had been expelled from the PZPR on the grounds that he had allegedly taken up an incorrect position in relation to the aggression of Israel against the Arab countries; he lost his party pension and then his job at the state press enterprise 'Ruch', having already been demoted to a lower position at an earlier juncture. ${ }^{68} \mathrm{He}$ was refused treatment at the hospital of the Ministry of Internal Affairs in Lublin. He was afraid to pick up the telephone: 'every day I received calls from the same troublemakers, telling me to leave the country, that I will be arrested if I don't leave, that it could cost me my life. ${ }^{69}$

Marek Kuperman blamed several individuals for his removal from the party, his place of work, and ZBoWiD - a number of named activists from the Lublin branch of the Union, whom he considered to be alcoholics, the director of the Lublin branch of 'Ruch', and a group of unnamed 'comrades from the Provincial Committee'. He wrote:

On the critical day of 6 June [1967], I went into ZBoWiD, where I met F. [and] S., who were holding a discussion with comrade Wajskop. When I opened the door, S. pulled me in and said 'here's another one.' I left straight away. And just a day after the speech

66 See e.g.: Eisler, pp. 127-130; Mieczysław F. Rakowski, Dzienniki polityczne. 1967-1968, Warszawa 1999, pp. 175f.

67 Rakowski, Dzienniki polityczne. 1967-1968, p. 225.

68 'List Marka Kupermana do Mieczysława Moczara' Lublin, 5 July 1968, AZGZKRPiBWP 3, 175, p. 288.

69 Ibid. 
of comrade Gomułka at the Trade Unions [Congress], ${ }^{70}$ on 20 June, F. and S. were telling people to denounce Jews. Then the City Commission for Party Control takes a decision without consultation to exclude me from the party. ${ }^{71}$

The director of 'Ruch' was said to have justified the dismissal of Kuperman at a meeting of the collective using the following words: 'Kuperman should not be allowed to move freely within the city of Lublin, to visit public institutions, so as not to spread the Zionist ideology. ${ }^{, 72}$

At this time, anti-Semitic statements were being made throughout the country at meetings of ZBoWiD's local-level directorates. One individual to make his views known was an official of the Warsaw regional directorate, who in March 1968 argued that there were two categories of citizens - and that 'citizens of Jewish extraction' belonged to the 'privileged class, who are in positions of power and receive very high salaries.' He therefore proposed that 'the party apparatus should be cleansed of them above all. ${ }^{73}$ A representative of ZBoWiD in Jadów, in Wołomin county, demanded that 'Jewish citizens, Zionists' should be expelled from the Union, the party, the government and armed forces, because 'Poland should be governed by Poles. ${ }^{74}$

\section{The innocent Poles and the ungrateful Jews}

The so-called Encyclopaedists' Affair was an important anti-Semitic event involving ZBoWiD. ${ }^{75}$ It was here that the competition between Polish and Jewish ethnic victimhood became a prominent feature of official memory practice. In July 1967, after the outbreak of the Six-Day War, the Ministry of Internal Affairs under Moczar's rule sent 'information concerning errors in the Great Universal Encyclopaedia [Wielka Encyklopedia Powszechna]', recently published by the most prestigious academic publisher Państwowe Wydawnictwo Naukowe (PWN),

70 In his speech given at the Trade Unions Congress on 19 June 1967 Władysław Gomułka suggested that Jews were a Zionist 'fifth column' in Poland who supported Israel against Arab countries. This speech is often considered by Polish historians as the official beginning of anti-Semitic campaign.

71 Ibid., p. 293.

72 Ibid., p. 288.

73 'Protokół z plenarnego posiedzenia Zarządu Okręgu Warszawskiego ZBoWiD', 14 March 1968; AAN, ZBoWiD ZG, 1, 390, p. 47.

74 'Protokół z plenarnego posiedzenia Zarządu Okręgu Warszawskiego ZBoWiD', 16 September 1968, ibid., p. 144.

75 Tadeusz P. Rutkowski, Adam Bromberg $i$ “encyklopedyści”. Kartka z dziejów inteligencji w PRL, Warszawa 2010. 
to the PZPR Central Committee and the Ministry of Justice. A similar letter was sent by Czesław Pilichowski of the Main Commission for Research into Hitlerite Crimes in Poland. Both letters accused the editors of the encyclopaedia of not providing enough information about murdered Poles (and Slavs in general), and thereby suggesting that Jews and Roma were the main victims of German crimes.

A Ministry of Internal Affairs document suggested that historical research had essentially become an act of political subversion by Jewish academics:

Since 1965, research in to the crimes of the Hitler regime in Poland has relied on criteria that have yielded the result that Hitlerite crimes against the Polish people have not been researched with the appropriate care. The Jewish Historical Institute has played a role in this neglect. A principle has been unjustifiably applied whereby only mass crimes are researched, numbering 100 murdered victims or more. The application of this principle has led to a preference for research in to crimes against Polish citizens of Jewish descent. ${ }^{76}$

The most significant political repercussions were felt in the spring of the following year: the editorial board of the encyclopaedia was disbanded, ${ }^{77}$ and an article by the well-known publicist Tadeusz Kur appeared in the daily newspaper Prawo $i$ Życie ('Law and Life') on 24 March 1968, entitled 'The Encyclopaedists' (Encyklopedyści). The Holocaust denying arguments presented in this article stirred public opinion to such an extent that the aphorism 'Kur knows better' (Kur wie lepiej) entered common usage, ${ }^{78}$ the author demonstrated scrupulously that in omitting Polish martyrdom, the editors had revealed their own excessive attachment to Jewish tradition. ${ }^{79}$

Local ZBoWiD activists were encouraged to demonstrate their indignation at the encyclopaedia's editors. ${ }^{80}$ The Secretariat of the Main Directorate advocated that 'the dramatic and heroic actions of the Polish nation during the Second World War should be described more broadly and more truthfully. ${ }^{\circ 1}$ At the same time, significant effort was made to highlight the heroism of Polish victims of Nazism and thereby to support the thesis that Poles had rescued thousands of Jews, putting

76 Cited in: Piotr Osęka, 'Encyklopedyści', Magazyn, a supplement to Gazeta Wyborcza, 5-7 March 1998.

$77 \mathrm{Ca} 40$ people lost their jobs, among them prominent communist activists of 1950 s, such as Stefan Staszewski, Jerzy Baumritter, Paweł Hoffman and Tadeusz Zabludowski.

78 This phrase is a play on words. Whilst Kur wie lepiej means 'Kur knows better', the phrase can also have a completely different meaning if rendered as Kurwie lepiej: 'the bastard has it better' [translator's note].

79 Osęka, 'Encyklopedyści'.

80 'Protokół nr 7 z posiedzenia Prezydium Zarządu Głównego ZBoWiD', 8 September 1967, AZGZKRPiBWP 3, 89, p. 218.

81 'Bieżąca informacja z prac Sekretariatu ZG ZBoWiD', 8 September 1967, ibid., p. 223. 
their own lives at risk. ${ }^{82}$ In February 1968, the presidium of the Main Directorate of ZBoWiD decided to distribute a questionnaire, with the aim of documenting this wartime aid. It was sent in 4,000 copies to local branches throughout the country. At the beginning of April 1968, the presidium of the Main Directorate passed the following resolution:

The task of identifying individuals who provided assistance to Jews during the occupation period should be taken up by ZBoWiD in conjunction with the Council for the Protection of Sites of Struggle and Martyrdom, academic institutions, the Main Commission for Research into Hitlerite Crimes in Poland and its regional affiliates, and also with help from teachers' associations, the scouts' movement, etc. It is necessary to organize a broad coalition centred around ZBoWiD in which all interested parties can participate and provide assistance. We must collect all available materials (testimonies and analytical works) ... In order to develop this initiative, the Secretariat will organize a conference for representatives of all interested institutions. We should not wait for the appearance of the final published version in book form, which Ksiażka $i$ Wiedza ['Book and Knowledge', a major publishing house] has agreed to undertake; instead, materials should be used for various publications in the meantime. These publications should also appear in foreign languages. Publishing on this topic is not an act of defence against Zionist attacks on the Polish people; it is directed at telling the historical truth about the attitudes of the Polish population to the Jewish population during the occupation period. ${ }^{83}$

An announcement was made in the press about the issuance of the questionnaire. The ZBoWiD Secretariat also demanded that a film be produced that would 'truthfully show the extent and costs of the efforts undertaken by Polish society and the Resistance Movement to save Jews from Hitlerite genocide. ${ }^{84}$

The myth of innocent victimhood facilitated the main paradox of the events of 1967-68: that the Jewish Holocaust in Poland became a topic of discussion during the anti-Semitic campaign. This was possible because the fate of the Jewish population of Poland served as a pretext for the activation of memory about Poles. In the late 1960s, when righteous Poles were being actively commemorated, no efforts were made by the Polish authorities to find Jewish survivors of the occupation; few Jews were invited to commemorative events as honoured guests or they refused to participate. In April 1968, the $25^{\text {th }}$ anniversary commemorations of the Warsaw Ghetto Uprising took place, as did the unveiling of the Jewish

82 The scope of actual support by Poles to Jews is still a matter of disagreement among historians. See for instance, Gunnar S. Paulsson, Secret City: The Hidden Jews of Warsaw, 1940-1945, New Haven 2002.

83 'Protokół nr 4 z posiedzenia Prezydium Zarządu Głównego ZBoWiD', 5 April 1968, AZGZKRPiBWP 3, 90, p. 356.

84 'Informacja Sekretariatu ZG ZBoWiD o ważniejszych pracach w marcu i kwietniu 1968', ibid., p. 364. 
pavilion at the State Museum at Auschwitz, i.e. the first significant display about Jews in the history of the museum. Representatives from Israel did not attend the event due to the international conflict, and Jewish groups in the West boycotted it due to the anti-Semitic campaign. ${ }^{85}$

The discrepancy between the official pronouncements being made by ZBoWiD and its practice is clearly illustrated by the organization's membership criteria: at a time when joining the Union was easier than ever before and almost anyone could become a member, people who had rescued Jews remained ineligible.

The works of Tadeusz Walichnowski, the best known ideologue of the antiSemitic propaganda of the day, provide a clue as to the international context behind the public image of Jews as ungrateful beneficiaries of Polish help. The book Izrael a NRF. 1949-1967 ('Israel and the FRG, 1949-1967') ${ }^{86}$ was awarded the highest prize of the Polish Institute of International Affairs; the book went through five editions in Polish and was translated into eight other languages. ${ }^{87}$ Walichnowski argued that Israel and the international 'Zionist circles' which supported the country had started a campaign against the Polish state, in return for financial and military help from West Germany. The author provided numerous quotes from the Western press as evidence that the campaign's central purpose was to discredit Poles as perpetrators of crimes against Jews:

The fact is that the territory of Poland during the occupation was covered by a Hitlerite killing network which created a Jewish cemetery. Despite the selfless, devoted activity of participants of the Polish resistance movement who worked to rescue Jews, despite the concealing of Jews by sections of the Polish population, the Hitlerites were able to murder (according to universally accepted figures) around 2.5 million Polish citizens of Jewish extraction and over a million Jews from other countries, in conditions of unparalleled terror.

The leaders of Zionism are now manipulating this painful truth, unleashing in Israel and on the territory of many countries of Western Europe and in the USA a campaign of slander against the Polish nation, which was subjected to those very same torments by the Hitlerite occupiers. Through the press, the radio, the television and various publications, the Poles are being presented as the main helpers of Hitlerite Germany in the extermination of the Jews. At the same time, Germany is being whitewashed via a conspiracy of silence about its crimes, a failure to examine the system of killing and the mass participation of citizens of the Third Reich in the so-called 'final solution to the Jewish problem'. The aim of the Zionist campaign is to distract the attention of

85 For details see: Huener, pp. 179f.

86 Tadeusz Walichnowski, Izrael a NRF. 1949-1967, Warszawa 1968 [1967].

87 The author also published two more books within a short time, as well as several articles on similar themes. Tadeusz Walichnowski, Mechanizm propagandy syjonistycznej, Katowice 1968; idem, Syjonizm a państwo żydowskie, Katowice 1968. Cf. Stola, Kampania antysyjonistyczna, p. 67, 68 . 
the world away from Hitlerite crimes against Jews by trying to make the Polish nation co-responsible for these crimes. ${ }^{88}$

According to Walichnowski, the 'Zionists' being paid by West Germany turned the world's attention away from German crimes on Polish territory, and thereby devalued the claim that Poland had the right to demand the recognition of the Oder-Neisse line by the FRG. ${ }^{89}$ In this way, Walichnowski carried out one of the most fundamental symbolic juxtapositions of the propaganda of March 1968, demasking the supposed alliance between the sworn enemies of Poland, the Germans, and the 'Zionists' (i.e. Jews).

Walichnowski's arguments were repeated frequently by representatives of the party, the state, as well as ZBoWiD. In January 1968, Kazimierz Rusinek explained that the Union should become more involved in international affairs, 'especially German affairs, that is, opposing the anti-Polish propaganda being spread by the FRG, and also certain circles in Israel. ${ }^{90}$ An article by an anonymous author entitled 'History, Tailor-Made' (Historia na obstalunek) was printed in Za Wolność $i$ Lud in this same month. For the local chapters of the Union, it became an essential document which provided instruction on how to interpret the 'Zionist assault':

\begin{abstract}
Millions murdered in the occupation period, people from many ghettos and camps ... If they could have foreseen that such a thing would happen now, 20-25 years later - that some of the very same people who survived the genocide would hand out olive branches to those who are guilty of the murder of their brothers, whilst holding us responsible to an ever increasing degree... And that the Israeli Jews would find themselves allied to the neo-fascists, that they would sing in unison, displaying an outright bestial hatred for Poles. No, not a single visionary prophet could have foreseen this. ${ }^{91}$
\end{abstract}

In a speech delivered in April 1968, Józef Cyrankiewicz, prime minister and still the chairman of the Supreme Council of ZBoWiD, stated that the anti-Polish campaign was being waged primarily by the press in West Germany, the United Kingdom, Israel and the USA. Its mechanism, according to Cyrankiewicz, was based on the propaganda methods developed by Joseph Goebbels. He emphasized that the campaign questioned the western border of Poland, and that the Poles were being blamed for the outbreak of the Second World War as well as accused of antiSemitism and of helping Hitler to murder Jews. ${ }^{92}$ The Polish media frequently

88 Walichnowski, Izrael a NRF, p. 164, 165.

89 Ibid., pp. $167 f$.

90 'Protokół nr 1 z posiedzenia Prezydium Zarządu Głównego ZBoWiD', 8 January 1968, AZGZKRPiBWP 3, 90, p. 285.

91 W.K., 'Historia na obstalunek', Za Wolność i Lud, 3 (1968), p. 4.

92 Józef Cyrankiewicz, 'Na straży naszej socjalistycznej drogi stoi klasa robotnicza', Trybuna Ludu, 11 April 1968, cited in: Jarosz, p. 116. 
quoted the following words by Mieczysław Moczar, spoken at the May plenary session of the Main Directorate of ZBoWiD:

Israel's shameful flirtation with West Germany, with the same people who for twenty years sent Jews to the gas chambers, has a political motivation. Israeli aggression against the Arab states is being accompanied by an anti-Polish campaign conducted worldwide by international Zionism. This campaign is being carried out using all of the contemporary means of mass communication, such as the press, cinematography, television, and literature - via all of the media on which the Zionists have an influence. This campaign must be met by us with protest and condemnation. In return for large damages being paid by the government of the FRG, International Zionism is seeking to perfidiously exculpate the Germans from the crimes they committed against Jews and perfidiously make the Poles co-responsible. ${ }^{93}$

In this way, the Polish collaboration with the Germans in the murder of Jews was made into a public affair, after firstly being filtered through propagandistic commonplaces. As a result, it was immediately subjected to public exorcism. This is why the Jews became, in the propagandistic imaginary of official Polish discourse, the ungrateful beneficiaries of Polish aid during the war. The image of the Jew-persecutor also featured from time to time in state propaganda; i.e., the Jewish people were blamed for the crimes of Stalinism, and contemporary Jewry and West Germany were identified as the joint enemies of the Polish nation. Moreover, the histories of two wars - the Second World War and the Six-Day War of 1967 - were fused together in public memory, in the same way that in Stalinist times, descriptions of American crimes in Korea were explicitly compared to the atrocities carried out by the Nazis (see Chapter 3).

Władysław Gomułka was the first to compare the Israeli attack on the Arab states to the Nazi invasion of Poland in 1939, stating that Israel 'looked to the Hitlerite Wehrmacht for models. ${ }^{94}$ He called Polish Jews who sympathized with Israel a 'fifth column'. Television programming on New Year's Eve 1967 featured a puppet show in which General Moshe Dayan was the main character; the choir sang 'Moshe, you are efficient like Heinz Guderian, wise like Keitel, brave as Rommel himself.' ${ }^{95}$ A reader of newspapers was likely to learn about Israeli Blitzkrieg, unjustified aggression, as well as lawless and brutal occupation. The press wrote about the introduction in Israel of bans on public assembly, persecution of the Arab population by the Zionists, the destruction of houses, numerous arrests on charges of sabotage and diversion, forced resettlement,

93 'Stenogram z posiedzenia Zarządu Głównego ZBoWiD', 4 May 1968, AZGZKRPiBWP 3 , 55, p. 7.

94 Władysław Gomułka, 'O nowej prowokacji Izraela na Bliskim Wschodzie', Trybuna Ludu, 22 June 1967, cited in: Jarosz, p. 102.

95 Eisler, p. 112, 113. 
cash fines for sheltering Arab soldiers, and also for illegal trade in food supplies. Israel's annexation of formerly Jordanian East Jerusalem was compared to the Third Reich's Anschluss of Austria. The Arab population's armed resistance was presented as inherently heroic; for example, a school strike by Arabs was praised, and successful skirmishes by the resistance movement were portrayed as glowingly positive. ${ }^{96}$ Allusions to the Third Reich's occupation of Poland were completely transparent.

Mieczysław Moczar, speaking on the radio about the suffering of the Arab population 'under the yoke of Israel', described a country 'on whose territory, even before last June, there existed ghettos for Arabs, ghettos organized by the same people who once worked as policemen in the Hitlerite ghettos of our cities. ${ }^{97}$ The media also presented cases of Jewish cooperation with the Germans during the war: articles were written about the Jewish police forces, the Judenräte and the Gestapo's Jewish informers. ${ }^{98}$ It was openly claimed that Jews who had collaborated with the Nazis during the war were now responsible for the persecution of Arabs.

This aggressive anti-Semitic rhetoric abated towards the end of 1968 . Nonetheless, the basic tenets of this propaganda were retained for a longer period. Alongside the myth of victory and the myth of unity, the myth of innocence became the third main narrative that told the story of the origins of socialist Poland. As a tale of the mass martyrdom of the nation in defence of a good cause, it sought to make sense of the suffering of the German occupation. It legitimized the system and, like the myth of unity, served an integrating function. Ethnic categories were employed in an attempt to show the martyrdom of Poles; at the same time, the possibility of Polish participation in the Holocaust was purged from public discourse. Suggestions that Jews had collaborated with the Germans were designed to deflect criticism away from Poles. The past was overlaid onto the present, with the war in the Middle East conceptualized through the prism of the Second World War. The myth of innocence was part of the discourse that attacked West Germany over its reluctance to pay reparations to victims, whilst accusing Israel of being in league with Poland's enemy. Based on the conviction that 'we Poles are being unjustly accused of crimes against Jews', the myth of innocence became one of the most important memory mechanisms used for the creation of social consensus.

96 Jarosz, p. 102, 103. See also: Osęka, Syjoniści, pp. 53-58.

97 Interview with Mieczysław Moczar. Channel One of Polskie Radio, 12 May 1968, OSA, Radio Free Europe Collection, POL 116-2, 300/50/1/1438.

98 Jarosz, p. 119. 


\section{KWIECIEN MIESIACEM PAMIECI NARODU}

Nigdy więej wojny Nigdy więcej Oświęcimia

\section{Precz z syjonizmem Prezz z faszyzmem}

Byli Więźniowie hitlerowskich obozów zagłady skupieni przy Zarzadzie Okręgu Zw. Bojowników o Wolność i Demokracje w Rzeszowie zapraszaja mieszkańców Rzeszowa na wielki:

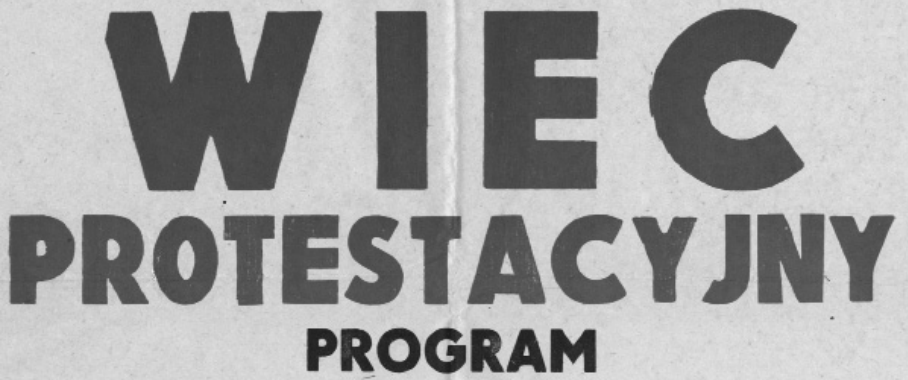

1. Otwarcie wiecu

2. Przemówienie okolicznościowe

3. Uchwalenie rezolucji

WIEC ODBĘDZIE SIĘ W DNIU 9 KWIETNIA 1968 R.

$$
\begin{gathered}
\text { O god z in i e } 17 \\
\text { PRZED POMNIKIEM ZWYCIĘSTWA }
\end{gathered}
$$

Zbiórka delegacii nastąpi o godz. 16 przed gmachem ZBoWiD przy ul. Szopena 23 skąd ulicami miasta ruszy p o c h ód na plac Zwycięstwa

\section{NIECH ZYJE PZPR PRZEWODNIA SILA MARODU}

5.3 In 1968, an anniversary of liberating concentration camps was used as a propaganda opportunity to equate Zionism with fascism. Captions run: 'No more war', 'No more Auschwitz', 'Stop Zionism', 'Stop fascism'. Rzeszów, April 1968. 
In September 1969, the Union held its Fourth Congress in the Congress Hall of the Palace of Culture and Science in Warsaw. It was a largely ritualistic event, which brought no significant changes in the composition of the Main Directorate. ${ }^{99}$ During the preparations for the Congress, ZBoWiD issued two important publications: a series of popular brochures about wartime events and a several-hundred page volume entitled Zbowidowcy. Tradycje i zadania ('People of ZBoWiD. Traditions and Tasks'), which featured a wealth of photographic material. This book can be read as a poignant summary of the public memory models that became accepted at the end of the 1960s. Many of the articles were written by professional historians, and presented the principal narratives of war that have been described here as the three dominant myths.

In contrast to the war narratives that were prevalent in the Stalinist years, the war stories were more detailed, featuring individual names and concrete sites of battle. At the same time, an emphasis was placed on the 'unity' of the aims of the various armed formations. Some themes were retained from the Stalinist discourse (e.g. the leading role of the PPR), but the broader context in which they were presented meant that these ideas were not as prominent as they had been previously. The figures of Joseph Stalin and the Polish pro-Soviet communists Wanda Wasilewska and Alfred Lampe, who were amongst the most important figures of war narratives in the years 1949-57, were conspicuous in their absence. A multiplex image of the military activities of the Home Army emerged. Rhetoric concerning the inter-war Polish state, and even the Polish government-in-exile, became more moderate; after all, they had created the Polish armed forces. Hitlerism was no longer presented as the final, degenerate form of imperialism, but a purely German invention. In the 1960s, nationalism became conclusively enmeshed in the revolutionary myth.

99 Mieczysław Moczar remained as chairman; Kazimierz Banach, Wojciech Jaruzelski, Włodzimierz Lechowicz, Jan Mazurkiewicz 'Radosław' and Zygmunt Netzer were reelected as deputy chairmen (Janusz Burakiewicz, a former concentration camp prisoner during the war, and a high-level bureaucrat in the state economy structures after the war, was the only new face among the deputy chairmen); Kazimierz Rusinek remained as secretary, with Henryk Matysiak as his deputy. 
Joanna Wawrzyniak - 978-3-653-99681-4

Downloaded from PubFactory at 01/11/2019 11:05:35AM

via free access 


\section{Afterword: The Long Shadow of the Communist Politics of Memory}

'The hero myth was also partly true, or true enough to make successive generations grateful.'

This book has tried, using both macro-political and micro-social perspectives, to outline the origins of three narratives that organized public memory of the Second World War under communism: the myth of victory over fascism, the myth of the unity of the Polish resistance and the myth of innocence. The principal subjects of these mythologies, the veterans and victims of the war, were coopted as participants in the state's memory policies; they effectively contributed to the transmission of the party's legitimizing vision. Fulfilling a public role as 'living symbols' of the Second World War, they consolidated the official stories of heroism and martyrdom via the media, school education, popular culture and state rituals, as well as via legal settlements that ruled on privileges that were of paramount importance for them. After 1956, the veterans' union was joined by people who were initially hostile to communist rule and the official memory narratives were thus challenged. The state responded by gradually increasing the social assistance available to veterans and victims of the war. This catch-all strategy, which was specific to communist corporatism, emerged as an effective method of legitimizing the political system. The history outlined in this book ends in the late 1960s because it was at this time that the war narratives of Eastern Europe's communist countries became consolidated and relations between the state and key memory groups were stabilized. Official memory of the war retained its essential contours until the fall of the state socialism two decades later.

The Polish case, despite certain peculiarities, was not exceptional or isolated. In these concluding remarks I will therefore place the history outlined in this book into a wider context of the post-war memory politics of Europe. Such a perspective makes it possible not only to discern the broader role played by the heroic narratives

1 Catherine Merridale, Ivan's War: Life and Death in the Red Army, 1939-1945, New York 2006, p. 375. 
that were formed and became hegemonic in communist Eastern Europe, but also to analyse the difficulties related to the inheritance of these forms of remembrance after the fall of communism. Two issues are of particular importance: first, the similarities and overlaps between the memory policies of the countries of the Eastern Bloc and Western Europe; second, the long shadow of the communist politics of memory in Eastern Europe in the years of systemic transition, despite the fact that many of the first-hand actors of the war, who had contributed to the formation of its public image under communism, were beginning to exit the scene.

\section{Polish War Memory in Comparative Context}

The diffusion of Soviet propaganda in the Eastern Bloc is an essential issue which is best understood within a comparative framework that makes visible certain key nuances of the outwardly monolithic memory policies of the communist countries. At the heart of Soviet public memory was a master narrative. The American social psychologist James V. Wertsch has argued that its basic plot consists of the following elements:

1. An 'initial situation'... in which the Russian people are living in a peaceful setting...

2. The initiation of trouble or aggression by an alien force, or agent, which leads to:

3. A time of crisis and great suffering, which is: 4 . Overcome by the triumph over the alien force by the Russian people, acting heroically and alone. ${ }^{2}$

According to Wertsch and his followers, this 'narrative template's underlies the most salient Russian histories, including the Mongol invasion and Napoleon invasion; ${ }^{4}$ it also lies beneath (changing) accounts of the Great Patriotic War. In the Soviet Union, it was articulated in the Marxist-Leninist terms of a struggle between the losing fascist and capitalist forces on the one hand, and, on the other, the victorious masses of soldiers, partisans and supporting local populations led by the communist party. ${ }^{5}$

In the course of the post-war decades, this Soviet narrative of the Great Patriotic War was spread beyond the borders of the USSR to Central and Eastern Europe. In Poland, it existed as a conglomerate of facts and legends, described as the myth of victory over fascism in Chapter 3 of this book. According to this narrative,

2 James V. Wertsch, Voices of Collective Remembering, Cambridge 2002, p. 93.

3 After Vladimir Propp, Wertsch maintains that 'schematic narrative template ... characterizes a broad range of narratives, as opposed to the particular events and actors that occur in specific ones' (ibid., p. 60).

4 Ibid., p. 94. See also e.g. Rauf Garagozov, Metamorfozy kollektivnoi pamiati v Rossii i na tsentral'nom Kavkaze, Baku 2005.

5 Wertsch, Voices, p. 81. 
the Soviet soldiers and partisans were heroic figures who helped their (lesser) Polish brothers-in-arms to combat the fascist enemy. However, a notable feature of post-war propaganda in the communist bloc was not the obvious diffusion of the Soviet narrative, but its ability to function simultaneously with local patterns of remembrance; and the fact that the Soviet policies facilitated the development of national distinctions. This heterogeneity has been elegantly presented by Serhy Yekelchyk, who applies a postcolonial approach to his research on Soviet Ukraine. He argues that Ukraine's public memory was at the same time a tool in the hands of Stalinist propaganda, whilst also being manipulated by Ukraine's cultural elites, who challenged Russia's imperial discourse dressed in internationalist rhetoric. Eventually, the national specificities of this discourse contributed to the collapse of the Soviet Union. ${ }^{6}$

In the Polish case, the local communists nursed and cherished an abundance of national traditions. However, the most salient aspect of their politics of memory was the semi-official maintenance of the romantic narrative template of the 'martyrdom' and 'resurrection' of Poland, an idea with roots in Poland's nineteenth-century independence movement against the great powers including imperial Russia. In the post-war years, this blueprint was revived with varying accents by both the Catholic Church and the communist party. In such a way, the most powerful and distinctive features of Polish cultural identity actually survived the communist period or were even strengthened, despite being in competition with the Soviet master narrative. According to this romantic blueprint, Poles also had to 'act heroically and alone' to overcome the enemy occupation. An important result of the turmoil of the Thaw of 1956, described in Chapters 4 and 5 as the myths of the unity of resistance and of innocent victims, was the state's search for internal legitimacy via the use of this template, which suggested that Poles rescued themselves independently of Moscow. Thus, the myth of the liberation by the Red Army was being undermined.

In this context, it is worth noting that the Polish communists after 1956 kept a keen eye on Yugoslavia. Memory politics in Yugoslavia and Poland were in many ways analogous to each other, because of well-organized partisan movements and

6 Serhy Yekelchyk, Stalin's Empire of Memory: Russian-Ukrainian Relations in the Soviet Historical Imagination, London-Toronto 2004. For similar arguments on former Soviet republics, see: Violeta Davoliūte, The Making and Breaking of Soviet Lithuania: Memory and Modernity in the Wake of War, New York 2013; Aliaksei Lastouski, 'Historical Memory as a Factor of Strengthening Belarusian National Identity' in Vjeran Pavlaković, Davor Pauković and Višeslav Raos (eds), Confronting the Past: European Experiences, Zagreb 2012, pp. 401-420; and Sigrid Rausing, History, Memory, and Identity in Post-Soviet Estonia, Oxford 2004, pp. 128-152. On other states of the Eastern Bloc, see above all Maria Bucur, Heroes and Victims: Remembering War in Twentieth-century Romania, Bloomington 2010. 
common difficulties in incorporating the wide political spectrum of wartime actors within the post-war order. In Yugoslavia, monarchist Chetniks and communists of the National Liberation Army had fought against each other, whilst the Croatian Ustashe formations had fought on the German side and operated one of the Europe's largest concentration camps for political prisoners at Jasenovac. Like in Poland, the propaganda of the Yugoslav authorities in the immediate postwar years aggrandized, above all, the communists. Later, the Tito regime and its principal vehicle of war memory, the Union of Fighters in the War of National Liberation, emphasized the 'unity' of the Yugoslav people in their fight against the Nazis, a myth that camouflaged past conflicts. The political situation in Yugoslavia was of course specific, as a result of the autonomy from the Soviet Union enjoyed by Tito - but this was a major reason why the Polish communists held Yugoslavia as a model. It was not only the country's rhetoric of national unity that appealed to the Poles, but also the dominant aesthetic of commemoration, which was less monumental than that of the USSR whilst also being universalistic: it emphasized the contribution of the local partisans to the liberation of the whole country. ${ }^{7}$

Another issue that is highly pertinent to the relationship between Polish and Soviet war memory is the way in which key memory groups were organized. On the surface, the central veterans' unions were analogous: ZBoWiD appears to be the equivalent of the Soviet Committee of War Veterans (SKVV). As noted in Chapter 1, the dynamics of the two organizations were similar: both were initially reduced to propagandistic dummies before re-emerging as important institutions representing well-defined interest groups. Characteristic similarities were observable in the late 1940s and 1950s in the relations between veterans and the state: 'Ivan's War' had ended with a populist promise that the soldier-heroes who had saved the USSR from fascist barbarism would be rewarded with both honours and respect from society. In Poland as well, promises were made to former soldiers that a new and better life awaited them in the 'Recovered Territories'. In both countries, this 'short honeymoon between veterans and the state came to an abrupt halt in 1947/48. ${ }^{8}$ Not only did the governments renege on their promises of social support and privilege, they also ceased to promote the soldiers' memories of the war. ${ }^{9}$ Also similar, to a certain extent, were the dominant cults of the soldiers and partisans in the later period, although they were built on different foundational myths in the two countries. As a result of these legitimizing hero

7 Karge, pp. 81-108.

8 Mark Edele, 'Collective Action in Soviet Society: The Case of War Veterans' in Golfo Alexopoulos, Julie Hessler and Kiril Tomoff(eds), Writing the Stalin Era: Sheila Fitzpatrick and Soviet Historiography, New York 2011, p. 121.

9 Merridale, p. 362. 
narratives, veterans eventually became a high-status social group in both Poland and the Soviet Union.

Nonetheless, it is of interest that SKVV and ZBoWiD differed in their chronologies of key wartime events. Although several aspects of the institutionalization of the veterans' movements were analogous to each other, this did not mean that events in Poland merely mirrored events in the USSR. Firstly, the origins and trajectories of the Polish and Soviet unions were different. The formation of ZBoWiD in 1949 was the culmination of a process of subordination, whereby independent grassroots associations of veterans and former prisoners were brought under the aegis of the state. In the first half of the 1950s, the monopolistic union played above all a propagandistic role, advancing the aims of the International Federation of Resistance Fighters (FIR). After 1956 it was reconstructed as part of the state's response to Polish society's dissatisfaction; it became an organization that represented the interests of veterans and former political prisoners. In contrast, in the Soviet Union in the late 1940s there were no independent associations of veterans, and Stalin explicitly forbade the formation of a nationwide union. SKVV was founded only in 1956 as a result of efforts by Khrushchev, who wanted a Soviet representative in the World Federation of Former Combatants (FMAC) in Paris. However, despite the party authorities' intention of creating a submissive organization that would restrict itself to fulfilling its designated role within FMAC, SKVV began to advance the social demands of Soviet veterans. ${ }^{10}$

Secondly, Poland was significantly quicker than the USSR in formalizing the status of veterans in law. Poland passed legislation that provided a complex formulation of the privileges of veterans and former prisoners in $1975 .{ }^{11}$ This move had been expected for a long time, and many of the privileges contained within this legislation had in fact been granted in the 1960s as separate statutes. The delay in approving a unified set of laws had been caused mainly by a fear that this would lead to an excessive strain on the state budget (Moscow faced a similar anxiety). For Polish veterans and former prisoners, the decade of Edward Gierek's rule (1970-80) was relatively favourable, as the expanding social aspirations of citizens were financed by Western loans. In contrast, in the Soviet Union the process of granting codified privileges to veterans of the Great Patriotic War was started only in 1978 and continued well into the 1980s and 1990s. ${ }^{12}$

Finally, and most importantly, the similar facades of ZBoWiD and SKVV concealed significant variations in their configurations of power and interest. In Poland, the most important memory groups included the former prisoners of Nazi concentration camps. Moreover, they comprised a separate group with more severe

10 Edele, 'Collective Action', p. 123.

11 Dz.U. 1975, nr 34, poz. 186.

12 Edele, 'Collective Action', p. 124, 125. 
experiences of the war than former Polish PoWs, who were treated by Germans in accordance with the Geneva Convention. Soviet soldiers, in contrast, were commonly held in concentration camps, and their treatment in PoW camps was extremely harsh. Additionally, after the war, Red Army soldiers who had suffered in the camps were treated with suspicion by the Soviet authorities as possible 'traitors' and as a result were often subjected to further persecution. ${ }^{13} \mathrm{Khrushchev}$ did distance himself from these policies of Stalin, by allowing former PoWs to join SKVV, yet nonetheless official memory of captivity during the war continued to be ambivalent and PoWs were not incorporated into the state's narrative as heroes. ${ }^{14}$ Meanwhile, in Poland former camps' inmates were among the primary groups that decided on the structure and organization of ZBoWiD, not least because of the role played by the sites of former camps (especially AuschwitzBirkenau) in the memory politics of the state. Whilst a number of Polish camp inmates were sentenced by the courts as kapo, it was practically unthinkable in Poland for all camp internees tout court to be treated as potential betrayers of the fatherland. In fact the opposite was true: they were one of the first memory groups to be heroized as 'political prisoners' and members of the 'resistance movement'although many Poles had ended up in the concentration camps not because of any political activity but as punishment for 'criminal' activities such as the smuggling of food. The role of 'traitors' or, at best, 'cowards' was however played by the former fighters of the Home Army in the first decade after the war.

The other countries of the Eastern Bloc spent most of the war on the side of the Axis powers, either through coercion or as a result of the calculated actions of their elites. For this reason, they did not become points of reference for the Polish communists in the manner of Yugoslavia and the USSR. Instead, their wartime histories were to be suppressed. It is symptomatic that the negative icon for the Polish saying 'Poland bred no Quislings' 15 was a Norwegian statesman and not, for example, Ferenc Szálasi, the Hungarian leader of the far-right Arrow Cross Party, or the Romanian conducător Ion Victor Antonescu, both of whom were in part responsible for the Holocaust in their respective territories. As a partial exception, Jozef Tiso, the head of Slovakia's pro-Nazi puppet government, was

13 Cf. Ulrike Goeken-Haidl, Der Weg zurück. Die Repatriierung sowjetischer Zwangsarbeiter während und nach dem Zweiten Weltkrieg, Essen 2006; Pavel Polian, Zhertvy dvukh diktatur: Zhizn', trud, unizhenie i smert' sovetskikh voennoplennykh i ostarbeiterov na chuzhbine i rodine, Moskva 2002.

14 Ramona Saavedra Santis, 'Zwischen “Sklaverei” und "Verrat”. Überlegungen zum Opferbild von Zwangsarbeiterinnen und Kriegsgefangenen in der Sowjetunion zwischen 1941 und 1991' in Ulf Brunnbauer, Andreas Helmedach and Stefan Troebst (eds), Schnittstellen: Gesellschaft, Nation, Konflikt und Erinnerung in Südosteuropa, München 2007.

15 See footnote 95 in Chapter 4. 
mentioned more frequently, probably because he was a priest - this made him a ready prop for the Polish communist authorities in their propaganda struggle against the Catholic Church. Nonetheless, on the whole, whenever the state's narratives dealt with the countries such as Bulgaria, Hungary or Romania, they tended to focus on the events of the last year of the war, when the communist resistance movement and the advancing Red Army 'liberated' the 'progressive' populations of this part of the continent.

The major exception to this policy of erasure was East Germany, which for political reasons (the priority of retaining the Oder-Neisse border in the face of opposition from the FRG) was communist Poland's second most important ally after the USSR. Official memory in Poland clearly differentiated 'bad' Germans (the West Germans) from the 'good' ones, who had allegedly formed an organized resistance movement against Hitler and, after suffering in the camps during the war, taken up residence in the GDR. As noted in Chapter 3, the Association of Persons Persecuted by the Nazi Regime (VVN) was an early ally of ZBoWiD and worked to consolidate the myth of victory against fascism. In the first half of the 1950s, both unions organized commemoratives events at the sites of former concentration and death camps that re-interpreted an 'unredeemable and senseless tragedy [as] a redemptive martyrdom that contributed to the victorious end of History.' ${ }^{\prime 6}$ VVN was dissolved in 1953 in the wake of anti-Semitic purges within the organization and replaced by the Committee of Anti-fascist Resistance Fighters (KdAW); thus, a union of the victims of persecution was substituted by a union of fighters, thereby strengthening the heroic interpretation of the fates of the prisoners.

Despite these differences, the major common trait of official war memory in Eastern Europe was the heroization of the victims. This mode of remembrance affected Jews, who were posthumously deprived of their ethnic identity, Polish civilians, many of whom had ended up in the camps for entirely prosaic reasons, or millions of Red Army recruits. The hero myth had its local variants, but was nonetheless universal because 'it glorified the brutal business of killing, and offered a cloak of indemnity for crimes that no one wanted to acknowledge. ${ }^{17}$ Any effort to get to grips with the real extent of support for the Nazis, the war crimes committed by the Red Army or NKVD, or the various local pogroms and ethnically-motivated vendettas would have had to blur the boundary between victim and perpetrator, something that ruling communists throughout Eastern Europe were unable or unwilling to do. After the purges of the early post-war years, communist rule was legitimized everywhere by boosting the collective pride of the nation through the cultivation of a positive myth.

16 Herf, p. 164.

17 Merridale, p. 372. 
Whilst a dominant mode of memory was consolidated in Eastern Europe, in the West there existed a greater number and variety of permitted memory groups and they were free to mobilize from the bottom-up. The intervention of the USA in the formation of the canons of memory in Western Europe was substantially smaller than the extent to which the Soviet Union interfered in the memory policies of the Eastern Bloc countries. ${ }^{18}$ Nonetheless, there are certain similarities that can be discerned in the patterns of public memory on the two sides of divided Europe in the first post-war decades. These include: the search for cohesive idioms that would enable the commemoration of the war within the realm of the nation state, especially using the principal tropes of heroization and victimization - as demonstrated in depth for France, Holland and Belgium by Pieter Lagrou; ${ }^{19}$ and the subordination of national memories of the war to the political demands of the Cold War. As a result, efforts to reach a differentiated understanding of individual experiences of the war, including the Holocaust, were marginalized, although not quite to the extent assumed until recently. ${ }^{20}$ Jeffrey Herf argues that in the 1950s 'restitution to Jewish survivors, and timely justice were peripheral issues in an era dominated ... by moral compromises that flowed from American and Western desires to integrate the West German into a new Western alliance. ${ }^{21}$

It was only in the 1960s and 1970s that a clear split began to form in terms of the politics of regret ${ }^{22}$ in the West and the politics of pride in the socialist East. The substantial literature on cultural memory in Western Europe makes it possible to highlight three key issues that enable a clearer understanding of the East-West divide. First, there was a generational change. From the 1960s, memory policy was increasingly directed not at the people who had experienced the war themselves, but at the generation born after 1945. The past gradually ceased to be an instrument for internal discussions among the war generation,

18 Sam Edwards, Allies in Memory: World War II and the Politics of Transatlantic Commemoration, c. 1941-2001, Cambridge 2015.

19 Lagrou, passim. Due to historical similarities, France was a state with which Poles were particularly fond of comparing their own country. Indeed, the attempts by Charles de Gaulle to unite a divided society by promoting the myth of the Résistance bore key similarities to the Polish national communists' creation of the myth of unity in the 1960s. De Gaulle himself was warmly welcomed during an official visit to Poland in 1967. See for instance Garret J. Martin, General de Gaulle's Cold War: Challenging American Hegemony, $1963-$ 68, New York 2013, pp. 155-158.

20 Cf. David Cesarani and Eric J. Sundquist (eds), After the Holocaust: Challenging the Myth of Silence, New York 2012.

21 Herf, p. 387.

22 Jeffrey K. Olick, The Politics of Regret: On Collective Memory and Historical Responsibility, New York 2007. 
and instead became a tool for the social formation of the youth. As many authors argue, the emerging generation was not just a fresh age cohort; the 1968-ers were a generation in the Mannheimian sense, who forged their own project of the future. ${ }^{23}$ This project entailed a radical revision of the interpretation of the past. As Gildea and Mark put it, 'coming to terms with the memory of the Second World War and its aftermath was a central part of how they understood their journey into radical political activity. ${ }^{24}$ In Western Europe, the 1968 generation built a new culture of memory that was more sensitive to the Holocaust. In contrast, in Eastern Europe the revisionist fervour of young dissident movements was directed more towards the resurrection of suppressed histories of the communist oppression. The policy makers in Eastern Europe were acutely aware of the generational change. In the 1960s, ZBoWiD considered its influence on the Polish youth to be as important as 'countering the propaganda of the FRG'; in a country where anti-German sentiment was a fundamental component of the legitimizing discourse, this was a significant statement of the importance of the generational turn. The situation was similar in Yugoslavia, where commemorative efforts that initially focused on veterans were redirected so as to concentrate on educational activities for the next generation. ${ }^{25}$ Moreover, in Western Europe, members of the 1968 generation went on to take up prominent positions of political influence, which for the Eastern European dissidents remained unattainable until after 1989.

Second, starting with the broadcast of the Adolf Eichmann trial in 1961, a major role in the de-heroization of the war in the West was played by the media. ${ }^{26}$ Film and television series about the Holocaust started to play an increasingly important role in the formation of cultural memory, ${ }^{27}$ at the same time that in the Eastern Bloc, images of Jewish suffering were subjected to ever harsher censorship ${ }^{28}$ because of Arab-Israeli wars. In Poland, this censuring of suffering

23 In the large literature on generations, memory and European identity, a particularly useful contribution is the recent analysis by Harald Wydra, 'Dynamics of Generational Memory: Understanding the East-West Divide', in Eric Langenbacher, Bill Niven, and Ruth Wittlinger (eds), Dynamics of Memory and Identity in Contemporary Europe, New York-London 2013, pp. 14-38.

24 James Mark and Robert Gildea, Conclusion: Europe's 1968, in Robert Gildea, James Mark and Annette Warring (eds), Europe's 1968, Oxford 2013, p. 327.

25 Karge, pp. 69-80.

26 David Cesarani (ed.), After Eichmann: Collective Memory and the Holocaust since 1961, London 2013.

27 See for instance: Toby Haggith and Joanna Newman (eds), Holocaust and the Moving Image: Representations in Film and Television since 1933, London 2005; Wulf Kansteiner, In Pursuit of German Memory: History, Television, and Politics After Auschwitz, Athens, Ohio 2006.

28 Cf. Marek Haltof, Polish Film and the Holocaust, Oxford 2012, pp. 115-138. 
was driven, inter alia, by attacks on unruly filmmakers by the veterans and former prisoners of ZBoWiD. The breaking of national mirrors by assessing the scale of collaboration with the Nazis of local populations began in Western Europe at various times and progressed at various rates, whereas in Eastern Europe it was only possible from the late 1980s and was begun in earnest after 1989.

Third, in Western Europe an ever-increasing role was played by German memory politics. As the principal defeated nation in Europe, Germany underwent various debates concerning its public memory of the war, ${ }^{29}$ with family remembrance patterns frequently proving resistant to the revision of dominant interpretations..$^{30}$ Nonetheless, a fundamental overall trend was towards the erosion of the image of the heroic soldier that had been so important in the interwar Germany; soldiers could, at best, be remembered as the victims of Hitler and Stalin, ${ }^{31}$ until subsequent generations turned the spotlight more brightly on the Wehrmacht's direct involvement in the atrocities of Nazism in the Eastern Europe. $^{32}$ (Since the 1980s, Germany has been one of the few countries in the world in which monuments have been erected to wartime deserters. ${ }^{33}$ ) In the search for a 'positive' model it was therefore easier to commemorate the civilian victims of the Allied bombings, ${ }^{34}$ and later to open up to the suffering of Jews; the Holocaust gradually became a central feature of German cultural memory of the war. ${ }^{35}$ The diffusion of Germany's anti-militaristic canon to other Western European countries was only a matter of time. The Holocaust became a focal

29 Norbert Frei, Adenauer's Germany and the Nazi Past: The Politics of Amnesty and Integration, New York 2002; Herf, pp. 201-396.

30 Harald Welzer, Sabine Moller and Karoline Tschuggnall, 'Opa war kein Nazi': Nationalsozialismus und Holocaust im Familiengedächtnis, Frankfurt am Main 2002.

31 James M. Diehl, The Thanks of the Fatherland: German Veterans After the Second World War, Chapel Hill 1993; Frank Biess, Homecomings: Returning POWs and the Legacies of Defeat in Postwar Germany, Princeton 2006. On Waffen-SS post-war organization see: Karsten Wilke, Die 'Hilfsgemeinschaft auf Gegenseitigkeit'(HIAG) 1950-1990. Veteranen der Waffen-SS in der Bundesrepublik, Paderborn 2011.

32 Christopher Browning, Ordinary Men: Reserve Police Battalion 101 and the Final Solution in Poland, New York 1992; Daniel Goldhagen, Hitler's Willing Executioners, New York 1996; Harald Welzer, Täter. Wie aus ganz normalen Menschen Massenmörder werden, Frankfurt am Main 2005; Sonke Neitzel and Harald Welzer, Soldiers: German POWs on Fighting, Killing, and Dying, New York 2012.

33 Steven R. Welch, "Commemorating "Heroes of a Special Kind": Deserter Monuments in Germany', Journal of Contemporary History 47, 2 (2012), pp. 370-401.

34 Jörg Arnold, The Allied Air War and Urban Memory: The Legacy of Strategic Bombing in Germany, Cambridge 2011.

35 Christoph Cornelißen, 'Was heißt Erinnerungskultur? Begriff-Methoden-Perspektiven', Geschichte in Wissenschaft und Unterricht 54 (2003), pp. 548-563. 
point of the normative model of war memory for Europe,$^{36}$ to a large extent as a result of the efforts of German intellectuals. When at the beginning of the 1990s the Holocaust had already been reconfigured in the West 'as a decontextualized event oriented toward nation-transcending symbols and meaning systems' for human rights', ${ }^{37}$ it acted as a canon of memory that collided with, and heavily affected, the processes of coming to terms with the past in the societies of Eastern Europe. ${ }^{38}$

\section{Communist Narratives: between Persistence and Change}

In 1990, the main protagonist of this book, ZBoWiD fell apart like a house of cards, from a monopolistic union to a disparate group of over a hundred different organizations of veterans and victims. ${ }^{39}$ The principal agents of public memory in Poland were joined by diasporic groups, some of whose representatives returned to their homeland, and also by victims of communist persecutions. ${ }^{40}$ Circles linked to the right-wing NSZ became more active. Jewish survivors and veterans were not numerous, but their presence in the memorial landscape was also cemented by Jewish associations. In addition, there emerged unions of children who had experienced the war. ${ }^{41}$ The post-communist Polish state energetically supported

36 Above all: Claus Leggewie, Anne Lang, Der Kampf um die europäische Erinnerung. Ein Schlachtfeld wird besichtigt, München 2011.

37 Daniel Levy and Natan Sznaider, The Holocaust and Memory in the Global Age, Philadelphia 2006; see also eadem, Human Rights and Memory, University Park, PA 2010.

38 Aleida Assmann, 'Europe's Divided Memory' in Uilleam Blacker, Alexander Etkind and Julie Fedor (eds), Memory and Theory in Eastern Europe, Basingstoke 2013, pp. 25-42.

39 ZBoWiD's principal successor was the Union of Veterans of the Republic of Poland and Former Political Prisoners (Zwiąek Kombatantów Rzeczypospolitej Polskiej i Bylych Więźniów Politycznych). The World Union of Home Army Soldiers (Światowy Zwiazek Żotnierzy Armii Krajowej), founded in 1990 by various post-AK organizations both in Poland and abroad, began to play a particularly important role in the public sphere. Lists of active Polish associations of veterans and victims are available at the website of the Office for Veterans' and Repressed Persons' Affairs: https://www.udskior.gov.p1/ (accessed August 2015).

40 For instance by the revived Union of Deportees to Siberia (Zwiazek Sybiraków), which brought together Poles deported to the Soviet Far East (it had existed in the inter-war period as a union of people persecuted by Tsarist Russia).

41 For instance, the Association of Children of the Holocaust in Poland (Stowarzyszenie Dzieci Holocaustu w Polsce) and the Association of Children of the War in Poland (Stowarzyszenie Dzieci Wojny w Polsce). 
veterans, through central institutions, such as the Office for War Veterans and Victims of Oppression (Urząd do Spraw Kombatantówi Osób Represjonowanych), the Council for the Protection of Sites of Struggle and Martyrdom, and the Institute of National Remembrance (IPN). Nonetheless, despite the activities of memory groups composed of first-hand participants of the war, public memory of those events began to be shaped to an increasing degree by people who had no direct experience of the war. ${ }^{42}$

This generation was faced with a legacy of myth and erasure of the memory politics of Polish national communism. The list of formerly suppressed histories that now started to resurface was particularly long. Arguably the most important were the histories of the Holocaust and Gulag. An influential essay by Tony Judt has advanced somehow orientalizing and essentializing model of Eastern Europe after 1989 as a region where 'the communist era... left a vacuum into which ethnic particularism, nationalism, nostalgia, xenophobia, and ancient quarrels could flow. ${ }^{43}$ From today's perspective it is rather clear that the communist mode of remembrance has held sway as an interpretive mechanism for subsequent generations. For instance, a nationwide survey carried out in 2009 showed that a majority of Poles positively evaluated the behaviour of their countrymen during the war: they believed that typical deeds included joining the armed resistance against the Nazis, condemning collaboration and helping Jews, whilst collaboration, indifference to the fate of the Jews and denunciation of Jews were considered to be rare. ${ }^{44}$ The results of this survey are interesting in that they show, on the one hand, a rejection of certain elements of communist propaganda (e.g. few respondents mentioned the Polish Armed Forces in the East), and on the other hand the persistence of communist-era narrative frameworks.

Nonetheless, throughout Eastern Europe public memory became a contested realm in which, to generalize broadly, critical history vied for supremacy with lingering heroic and martyrological narratives. This discursive battle is played out in a variety of configurations in different countries of the region. ${ }^{45}$ The German historian Stefan Troebst, who in his research on East European memory cultures

42 For an extensive overview of post-1989 memory processes in Poland, see Ewa Ochman, Post-Communist Poland - Contested Pasts and Future Identities, London 2013.

43 Tony Judt, 'The Past Is Another Country: Myth and Memory in Postwar Europe', Daedalus 121, 4 (1992), pp. 83-118.

44 Piotr T. Kwiatkowski, Lech Nijakowski, Barbara Szacka, and Andrzej Szpociński, Między codziennością a wielką historiq. Druga wojna światowa w pamięci zbiorowej społeczeństwa polskiego, Gdańsk-Warszawa 2010, p. 147.

45 The literature on collective memory processes in Eastern Europe is steadily growing. For a summary article see Joanna Wawrzyniak and Małgorzata Pakier, 'Memory Studies in Eastern Europe: Key Issues and Future Perspectives', Polish Sociological Review 183, 3 (2013), pp. 257-279. 
operates in the tradition of Oskar Halecki's meso-regions and uses Klaus Zernack's concept of Geschichtsregionen, has proposed a useful typology of these cultures: (1) countries with an anti-communist consensus (the Baltic States); (2) countries with fierce public debates on recent history (Hungary, Poland); (3) countries where apathy and ambivalence dominate (Bulgaria, Romania); and (4) countries where communism has not been entirely de-legitimized (Belarus, Moldova) ${ }^{46}$ Poland therefore belongs to a group of countries in which the past is subjected both to continued romanticization and revision.

To give the most salient examples: on the one hand, the romantic-nostalgic wave gave rise to the widespread expectation that the post-socialist democratic state would 'tell the truth' about the contemporary history and pass judgement not only on the Nazi occupation, but also on the communist dictatorship. The main institution responsible for this process was the Institute of National Remembrance (probably the largest institution of its kind in Europe), which was tasked with a set of archival, educational and research responsibilities including the prosecution of Nazi and communist crimes. Thus, from the very beginning, the IPN was intended to be a guardian of national and community values rather than an institution for the critical study of history. ${ }^{47}$ In the 1998 Act that created the IPN, there were references to the need to cultivate the memory of 'the sacrifice, loss and damage suffered by the Polish nation in the years of the Second World War and after its conclusion' and 'the patriotic traditions of the struggle of the Polish nation with its occupiers, with Nazism and Communism. ${ }^{38}$ This approach to the discourse of national martyrdom has also been supported in several exhibitions, with the Museum of the Warsaw Uprising taking the lead. Its permanent exhibition, opened in 2004, criminalizes Soviet communism, equates it with Nazism, and treats the national memory of the uprising as historical 'truth'. ${ }^{49}$ In this way, despite cutting off the ties with communism, the post-communist institutions of memory sometimes follow the blueprint of its unequivocal memory politics.

46 Stefan Troebst, 'Halecki Revisited: Europe's Conflicting Cultures of Remembrance', in Małgorzata Pakier and Bo Stråth (eds), A European Memory? Contested Histories and Politics of Remembrance, New York 2010.

47 Dariusz Stola, 'Poland's Institute of National Remembrance: Ministry of Memory' in Alexei Miller and Maria Lipman (eds), Convolutions of Historical Politics, Budapest 2012, pp. 45-58.

48 Dz.U. $1998 \mathrm{nr} 155$ poz. 1016.

49 Cf. Monika Żychlińska and Erica Fontana, 'Museal Games and Emotional Truths: Creating Polish National Identity at the Warsaw Rising Museum', East European Societies and Politics, first published on May 11, 2015 as doi:10.1177/0888325414566198. More on recent historical museums development in Eastern European courtyard: Zuzanna Bogumił, Joanna Wawrzyniak et al., Enemy on Display: The Second World War in Eastern European Museums, New York 2015, pp. 133-150. 
As for the proponents of a critical discourse, they have largely been influenced by international studies on Holocaust memory and an awareness of human rights. Their focus is to disavow the self-congratulatory narrative of national pride and martyrdom. Here too, the actors are numerous and include politicians, artists, researchers and NGO activists. Among the triggers of the most heated discussions were books by historian Jan Tomasz Gross: Neighbors (2000), Fear (2008) and Golden Harvest (2011), which deal with the involvement of Poles in wartime genocide, the plundering of Jewish property and post-war pogroms. ${ }^{50}$ Gross's accounts gave rise to heated public debates on Polish guilt and aroused an interest in the growing number of publications on the Holocaust and Polish-Jewish relations. The Polish Centre for Holocaust Research, established in 2003 at the Institute of Philosophy and Sociology of the Polish Academy of Sciences, has played a major role in this development. In a sense, institutions like the Centre for Holocaust Research and the IPN have been in competition with each other to propagate different interpretations of history. ${ }^{51}$ Suffice to say that the more cases of anti-Jewish violence were brought to light by Holocaust scholars, the more energy was invested by other groups in commemorating Polish righteousness.

One of the most significant achievements in an international perspective has been the elaboration of the complexities of past Polish-German relations. ${ }^{52}$ Also, after the Orange Revolution (2004-2005) and the Crimea crisis (2014) in Ukraine, readiness increased to engage in dialogue with Ukraine on a variety of matters, including the conflicts of the Second World War. ${ }^{53}$ Polish-Russian inter-state relations remain the greatest difficulty, whereby unprocessed historical traumas continue to affect the current political situation. The advancement by conservative circles of the double genocide thesis (with Nazi and communist rule in the same 'totalitarian' category) is one of salient trends in the context of regional memory. That trend is, in a way, a return to the ideas put forward

50 Cf. Joanna Michlic and Małgorzata Melchior, 'The Memory of the Holocaust in Post1989: Renewal-Its Accomplishments and Its Powerlessness' in John-Paul Himka and Joanna Michlic (eds), Bringing the Dark Past to Light: The Reception of the Holocaust in Postcommunist Europe, Lincoln 2013, pp. 403-450; Piotr Forecki, Reconstructing Memory: The Holocaust in Polish Public Debates, Frankfurt am Main 2013.

51 Still, IPN has also published valuable studies that shed light on the anti-Jewish violence in Poland. For instance Paweł Machcewicz and Krzysztof Persak (eds), Wokót Jedwabnego, vols 1-2, Warszawa 2002.

52 Kristin Kopp and Joanna Niżyńska, Germany, Poland and Postmemorial Relations: In Search of a Livable Past, New York 2012.

53 Łukasz Sommer and Joanna Wawrzyniak, 'The Ukrainian Crisis in the Polish Media', in The Ukrainian Crisis in the European Media and the Public Sphere "Cultures of History" Forum, Version: 1.0, 02.06.2014, URL: http://www.imre-kertesz-kolleg.uni-jena.de/index. php?id=578. 
during the German Historikerstreit ('Historians' Debate') in the late 1980s. These tendencies are especially visible not only in Poland, but also in the Baltic States, Hungary and Slovakia. There has been some concerted lobbying at the EU level for an expansion of Gulag memory and for the date of the Molotov-Ribbentrop Pact (23 August 1939) to be designated a day of remembrance, but this has failed to create a set of common sites of memory in Eastern Europe. ${ }^{54}$

All in all, the post-1989 politics of the Second World War in Poland has been diversified, with various actors advancing different agendas. However, ironically, the anti-communist populist and conservative circles have tended to use the communist narrative forms that originated in the 1960s. Their tendency toward 'heroic victimhood nationalism', to paraphrase a term proposed by Korean historian Jie-Hyun Lim, ${ }^{55}$ has only been strengthened today in their reactions to Russia's memory policies, which in turn recycle the Stalinist expansionist propaganda of the 1950s. The heated debates, the unconscious use of communist clichés and recent developments in the face of the Ukrainian crisis clearly show that Poland has not as yet come to the terms with its violent past.

54 Lidia Zessin-Jurek, 'The Rise of and East European Community of Memory? On Lobbying for the Gulag Memory via Brussels', in Małgorzata Pakier and Joanna Wawrzyniak (eds), Memory and Change in Europe: Eastern Perspectives, forthcoming [New York 2015], pp. 131-149.

55 Jie-Hyun Lim, 'Victimhood Nationalism in Contested Memories: National Mourning and Global Accountability', in Aleida Assmann and Sebastian Conrad (eds), Memory in a Global Age: Discourses, Practices and Trajectories, Basingstoke 2010, pp. 138-162. 
Joanna Wawrzyniak - 978-3-653-99681-4

Downloaded from PubFactory at 01/11/2019 11:05:35AM

via free access 


\section{Bibliography}

\section{Archives}

Archiwum Akt Nowych

Grupa Akt ZBoWiD, file (teka): 2

Komitet Centralny PZPR, files: VII, 2205, 2672; VIII, 68, 368, 369, 917; XXVI, 6

Związek Bojowników o Wolność i Demokrację, Zarząd Główny 1, files: 1, 4, 12, $16,210,223,380,387,390$

Archiwum Instytutu Pamięci Narodowej

0330/217, file: 2

00231/182, file: 1

00231/176, files: 2,6

0648/152, files: 1,2

$765 / 335$

MSW II, files: 3854,3860

Archiwum Państwowe m.st. Warszawy

Komitet b. Jeńców Oflagu II C, file: 1

KW PZPR, files: 198, 242

Archiwum Zarządu Głównego Związku Kombatantów

Rzeczpospolitej Polskiej i byłych Więźniów Politycznych

3, files: 3, 7, 11, 16-19, 22, 28-40, 43, 44, 46, 49, 55, 66-70, 72, 74, 76, 77, 78, $80,81,85-90,102,107,108,156 / 1,156 / 2,157 / 1,170 / 2,171,175$

8 , files: $1,2,5$

11, files: 9,10

Biblioteka Narodowa

DŻS, I $3 \mathrm{k}$

Centralne Archiwum Wojskowe

Główny Zarząd Polityczno-Wychowawczy Wojska Polskiego

IV 502/1, files: 13, 587, 590, 592, 593 
Open Society Archives

Radio Free Europe Collection, POL 116-2, 300/50/1/1438

\section{Interviews (audio recordings in the author's archives)}

C.Z. November 2004; S.M. and E.S. June 2005; I.G. May 2005; I.M. April 2005; S.M. July 2004; P.B. July 2004; T.P. July 2004; W.G. July 2004

\section{Newspapers, magazines and other periodicals}

Biuletyn Głównej Komisji Wspótpracy z Młodzieżą ZBoWiD

Biuletyn Informacyjny (Zarząd Główny ZBoWiD)

Gazeta Ludowa

Kultura

Nowa Kultura

Ogniwa

Po prostu

Polityka

Polska Niepodległa

Przegląd Lekarski - Oświęcim

Trybuna Ludu

Tygodnik Powszechny

Wolni Ludzie

Za Wolność i Lud

Żotnierz-Osadnik

\section{Journal of Laws of the Republic of Poland}

'Dz.U.' refers to Dziennik Ustaw, the Journal of Laws of the Republic of Poland. References to this source conventionally give an issue number for the year in question ('nr'), and the 'position' (poz.) within the volume of the statute in question; the latter does not correspond to a page number. All of these texts can be accessed individually online, at http://dokumenty.rcl. gov.pl/.

Dz.U. 1944 nr 12, poz. 91 i 92; Dz.U. 1944 nr 15, poz. 81; Dz.U. 1945 nr 7, poz. 61; Dz.U. 1945 nr 17, poz. 97; Dz.U. 1945 nr 22, poz. 22; Dz.U. 1945 nr 28, poz. 121; Dz.U. 1945 nr 30, poz. 179; Dz.U. 1945 nr 30, poz. 180; Dz.U. 1945 nr 30, poz. 181; Dz.U. 1945 nr 34, poz. 202; Dz.U. 1945 nr 50, poz. 285, 286, 287 i 288; Dz.U. 1945 nr 51, poz. 294; Dz.U. 1945 nr 55, poz. 434 i 442; Dz.U. 1945 nr 65, poz. 528; Dz.U. 1946 nr 14, poz. 101; Dz.U. 1946 nr 37, poz. 228; Dz.U. 1946 nr 64, poz. 340; Dz.U. 1946 nr 73, poz. 397; Dz.U. 1947 nr 14, poz. 54; Dz.U. 1947 nr 
43, poz. 226; Dz.U. 1948 nr 56, poz. 387; Dz.U. 1949 nr 25, poz. 182; Dz.U. 1954 nr 37, poz. 159; Dz.U. 1954 nr 30, poz. 116; DZ.U. 1968 nr 20 poz. 127; Dz.U. 1975 nr 34, poz. 186; Dz.U. 1998 nr 155 poz. 1016; Dz.U. 2002 nr 42, poz. 371.

\section{Published Sources}

Bielecki, Robert (ed.), Żolnierze Powstania Warszawskiego. Dokumenty z Archiwum Polskiego Czerwonego Krzyża, vols 1-3, Warszawa: Neriton, 1997.

Dudek, Antoni, Aleksander Kochański and Krzysztof Persak (eds), Centrum wladzy. Protokoty posiedzeń kierownictwa PZPR. Wybór z lat 1949-1970, Warszawa: ISP PAN, 2000.

Gomułka, Władysław, Artykuły i przemówienia, vol.1, Warszawa: Książka i Wiedza, 1962.

Heda, Antoni, Wspomnienia „, Szarego”, Warszawa: Interim, 1991.

II Kongres ZBoWiD. 1-3 września 1959, Warszawa: ZG ZBOWiD, 1959

Kirchmayer, Jerzy, Powstanie warszawskie, Warszawa: Książka i Wiedza, 1959.

Kirchmayer, Wanda, Z Jerzym na dobre i złe, Warszawa: Oficyna Wydawnicza Labos, 1992.

Kliszko, Zenon, Powstanie warszawskie. Artykuły, przemówienia, wspomnienia, dokumenty, Warszawa: Książka i Wiedza, 1964.

Kochański, Aleksander (ed.), Protokoły posiedzeń Sekretariatu KC PPR 19451946, Warszawa: ISP PAN, 2001.

Kochański, Aleksander (ed.), Protokoty z posiedzeń Biura Politycznego KC PPR 1947-1948, Warszawa: ISP PAN, 2002.

Kongres Związu Bojowników o Wolność i Demokrację. Warszawa 1 IX 1949, Warszawa: ZG ZBoWiD, n.d.

Krawczyński, Roman, Wspomnienia lubelskiego kronikarza. Więzienie - obóz w Stutthofie - praca zawodowa i spoleczna 1944-1969, Lublin: self-published, 2002.

Malinowski, Marcin, et al. (eds), Polska Partia Robotnicza. Dokumenty Programowe 1942-1948, Warszawa: Książka i Wiedza, 1984.

Mazurkiewicz, Stanisław, Jan Mazurkiewicz. „Radosław”, „Sep”, „Zagłoba”, Warszawa: self-published, 1994.

Moczar, Mieczysław, Barwy walki, Warszawa: KAW, 1979.

Namiotkiewicz, Walery and Bogdan Rostropowicz, Ludzie, fakty, refleksje, Warszawa: MON, 1961.

Nowak-Jeziorański, Jan, Polska wczoraj, dziś i jutro, Warszawa: Czytelnik, 1999. Nowak-Jeziorański, Jan, Polska z oddali. Wojna w eterze - wspomnienia, London: Odnowa, 1988. 
O działalności $i$ aktualnych zadaniach ZBoWiD. Posiedzenie Rady Naczelnej ZBoWiD, Warszawa: ZG ZBoWiD, 1966.

$O$ zadaniach Związku Bojowników o Wolność $i$ Demokrację $w$ okresie poprzedzajacym IV Krajowy Kongres, Warszawa: ZG ZBoWiD, 1968.

Pamiętnik II Krajowego Zjazdu Lekarzy Zwiąku Bojowników o Wolność i Demokrację z dnia 28-28 maja 1968 roku, Warszawa: Państwowy Zakład Wydawnictw Lekarskich, 1969.

Pióro, Tadeusz, Armia ze skazq. W Wojsku Polskim 1945-1968 (wspomnienia i refleksje), Warszawa: Czytelnik, 1994.

Poksiński, Jerzy, Aleksander Kochański and Krzysztof Persak (eds), Kierownictwo PPR i PZPR wobec wojska 1944-1956, Warszawa: ISP PAN, 2003.

Polski ruch narodowo-wyzwoleńczy w latach 1939-1945. Materiaty do zajęć seminaryjnych dla oficerów, Warszawa: Zarząd Propagandy i Agitacji Głównego Zarządu Politycznego [Wojska Polskiego], 1957.

Przewodnik po upamiętnionych miejscach walk i męczeństwa lat wojny 19391945, Warszawa: Rada Ochrony Pamięci Walki i Męczeństwa, 1964.

Rakowski, Mieczysław F. Dzienniki polityczne 1963-1966, Warszawa: Iskry, 1999. Rakowski, Mieczysław F., Dzienniki polityczne 1958-1962, Warszawa: Iskry, 1998. Rakowski, Mieczysław, F., Dzienniki polityczne 1967-1968, Warszawa: Iskry, 1999. Ramowe wytyczne dla kót i oddziałów ZBoWiD, Warszawa: ZG ZBoWiD, 1963. Roczniki Statystyczne 1961-1969, Warszawa: GUS, 1962-1970.

Rzepecki, Jan, Wspomnienia i przyczynki historyczne, Warszawa: Czytelnik, 1956. Sawicki, Jacek Z. (ed.), Aresztowane Powstanie, Warszawa: IPN, 2004.

Sprawozdanie $z$ działalności klubu byłych więźniów politycznych obozu koncentracyjnego Gross-Rosen przy zarzadzie okregu warszawskiego ZBoWiD za okres od 1961 do 31 kwietnia 1963, Warszawa: ZBoWiD, 1963. Sprawozdanie z działalności w latach 1960-1964, Warszawa: ZG ZBoWiD, 1964. Torańska, Teresa, Oni, Warszawa: Świat Książki, 1987.

Uprawnienia kombatantów oraz członków ich rodzin $w$ zakresie emerytur, rent i innych świadczeń socjalnych, ZUS, Warszawa 1979.

Walichnowski Tadeusz, Syjonizm a państwo żydowskie, Katowice: „Śląsk”, 1968. Walichnowski, Tadeusz, Izrael a NRF. 1949-1967, Warszawa: Książka i Wiedza, 1968.

Walichnowski, Tadeusz, Mechanizm propagandy syjonistycznej, Katowice: „Śląsk”, 1968.

Załuski, Zbigniew, Siedem polskich grzechów głównych, Warszawa: Czytelnik, 1962.

Zbowidowcy. Tradycje i zadania, Warszawa: ZG ZBoWiD, 1969. 


\section{Books and Articles}

Anderson, Benedict, Imagined Communities: Reflections on the Origin and Spread of Nationalism, London: Verso, 1983.

Arnold, Jörg, The Allied Air War and Urban Memory: The Legacy of Strategic Bombing in Germany, Cambridge: Cambridge University Press, 2011.

Assmann, Aleida, 'Speichergedächtnis und Funktionsgedächtnis in Geschichte und Gegenwart' in Peter Rusterholz and Rupert Moser (eds), Wir sind Erinnerung, Bern: Haupt Verlag, 2003.

Assmann, Aleida, 'Europe's Divided Memory' in Uilleam Blacker, Alexander Etkind and Julie Fedor (eds), Memory and Theory in Eastern Europe, Basingstoke: Palgrave Macmillan, 2013.

Assmann, Aleida, Erinnerungsräume. Formen und Wandlungen des kulturellen Gedächtnisses, München: C.H. Beck Verlag, 2010.

Assmann, Jan, Das kulturelle Gedächtnis. Schrift, Erinnerung und politische Identität in frühen Hochkulturen, München: C.H. Beck Verlag, 1992.

Baczko, Bronisław, Les imaginaires sociaux. Mémoires et espoirs collectifs, Paris: Payot, 1984.

Banas, Josef, The Scapegoats: the Exodus of the Remnants of Polish Jewry, London: Weidenfled and Nicolson, 1979.

Bębenek, Stanisław, Myślenie o przeszłości, Warszawa: PIW, 1981.

Berendt, Grzegorz, August Grabski and Albert Stankowski, Studia z historii Żydów w Polsce po 1945 roku, Warszawa: Trio, 2000.

Berger, Peter L. and Thomas Luckman, The Social Construction of Reality: A Treatise in the Sociology of Knowledge, Garden City, NY: Anchor Books, 1966.

Biernat, Tadeusz, Mit polityczny, Warszawa: PWN, 1989.

Biess, Frank, Homecomings: Returning POWs and the Legacies of Defeat in Postwar Germany, Princeton: Princeton University Press, 2006.

Bingen, Dieter, Polityka Republiki Bońskiej wobec Polski. Od Adenauera do Kohla 1949-1991, Kraków: Kwadrat 1997.

Bischof, Günter, Stefan Karner and Peter Ruggenthaler (eds), The Prague Spring and the Warsaw Pact Invasion of Czechoslovakia in 1968, Plymouth: Lexington Books, 2010.

Błesiński, Jan et al., Ruch kombatancki na Warmii i Mazurach w latach 19451985, in Ruch kombatancki na Warmii i Mazurach w latach 1945-1985, Olsztyn: Zarząd Wojewódzki ZBoWiD, 1985.

Bogumił, Zuzanna, Joanna Wawrzyniak et al., Enemy on Display: The Second World War in Eastern European Museums, New York-Oxford: BerghahnBooks, 2015. 
Borkiewicz, Adam, Powstanie warszawskie 1944. Zarys działań natury wojskowej, Warszawa: PAX, 1957.

Browning, Christopher, Ordinary Men: Reserve Police Battalion 101 and the Final Solution in Poland, New York: HarperCollins, 1992.

Brudny, Yitzhak M., Reinventing Russia: Russian Nationalism and the Soviet System, 1953-1991, Cambridge: Cambridge University Press, 1998.

Brzostek, Błażej and Joanna Wawrzyniak, „Wiklina”. Z historii pewnej kawiarni czasów małej stabilizacji, in Janusz Żarnowski (ed.), Metamorfozy społeczne, vol.2,Warszawa: Neriton-IH PAN, 2007.

Bucur, Maria, Heroes and Victims: Remembering War in Twentieth-century Romania, Bloomington: Indiana University Press, 2010.

Bunce, Valerie and John M. Echols, 'Pluralism, Corporatism and the Soviet Union' in Susan Gross Solomon (ed.), Pluralism in the Soviet Union: Essays in Honor of H. Gordon Skiiling, New York: St. Martin's Press, 1983.

Cesarani, David (ed.), After Eichmann: Collective Memory and the Holocaust since 1961, London-New York: Routledge, 2013.

Cesarani, David and Eric J. Sundquist (eds), After the Holocaust: Challenging the Myth of Silence, London-New York: Routledge, 2012.

Chęciński, Michał, Poland: Communism, Nationalism, Anti-Semitism, New York: Karz-Cohl Publishing, 1982.

Chiari, Bernard in collab. with Jerzy Kochanowski (eds), Die polnische Heimatarmee. Geschichte und Mythos der Armia Krajowa seit dem Zweiten Weltkrieg, München: Oldenbourg Verlag, 2003.

Chirot, Daniel, 'The Corporatist Model and Socialism', Theory and Society 2, 9 (1980).

Cohen Lenard J. and Jane P. Shapiro (eds), Communist Systems in Comparative Perspective, New York: Anchor/Doubleday, 1974.

Cornelißen, Christoph, 'Was heißt Erinnerungskultur? Begriff-Methoden-Perspektiven', Geschichte in Wissenschaft und Unterricht 54 (2003).

Davoliūte, Violeta, The Making and Breaking of Soviet Lithuania: Memory and Modernity in the Wake of War, London-New York: Routledge, 2013.

Deák, István, 'Introduction' in The Politics of Retribution in Europe: World War II and its Aftermath, István Deák, Jan T. Gross, and Tony Judt (eds), Princeton: Princeton University Press, 2000.

Diehl, James M., The Thanks of the Fatherland: German Veterans After the Second World War, Chapel Hill: University of North Carolina Press, 1993.

Dinwebel, Władysław, 'Wojskowa akcja osadnicza w powiecie Lwówek Śląski' Polska Ludowa 2 (1963).

Dmitrów, Edmund, Niemcy i okupacja w oczach Polaków. Poglady i opinie z lat 1945-1948, Warszawa: Czytelnik, 1987. 
Doroszewski, Witold and Stanisław Skorupka (eds), Słownik języka polskiego, Warszawa: PWN, 1964.

Drygalski, Jerzy and Jacek Kwaśniewski, 'No-Choice Elections', Soviet Studies 2, 42 (1990).

Dziurzyński, Patrycy, 'Udział WP w zasiedlaniu Ziem Odzyskanych', Przeglad Zachodni 1-2, 23 (1967).

Eberhardt, Adam et al., 'Szkody wyrządzone Polsce podczas II wojny światowej przez agresora niemieckiego. Historia dociekań i szacunków’ in Witold M. Góralski (ed.), Problem reperacji, odszkodowań $i$ świadczeń $w$ stosunkach polsko-niemieckich, 1944-2004, vol. 1, Warszawa: PISM, 2004.

Edele, Mark, 'Collective Acton in Soviet Society: The Case of War Veterans' in Golfo Alexopoulos, Julie Hessler and Kiril Tomoff (eds), Writing the Stalin Era: Sheila Fitzpatrick and Soviet Historiography, New York: Palgrave Macmillan, 2011.

Edele, Mark, Soviet Veterans of the Second World War: A Popular Movement in an Authoritarian Society, 1941-1991, Oxford: Oxford University Press, 2008.

Edmund Dmitrów, 'Pamięć i zapomnienie w stosunkach polsko-niemieckich', Przegląd Zachodni 1, 45 (2000).

Edwards, Sam, Allies in Memory: World War II and the Politics of Transatlantic Commemoration, c. 1941-2001, Cambridge: Cambridge University Press, 2015.

Eichenberg, Julia and John Paul Newman, 'Introduction: The Great War and Veterans' Internationalism' in Julia Eichenberg and John Paul Newman (eds), The Great War and Veterans' Internationalism, London: Palgrave Macmillan, 2013.

Eichenberg, Julia, Kämpfen für Frieden und Fürsorge. Polnische Veteranen des Ersten Weltkriegs und ihre internationalen Kontakte, 1918-1939, München: Oldenbourg Verlag, 2011.

Etkind, Alexander, Rory Finnin et al., Remembering Katyn, Cambridge: Cambridge University Press, 2012.

Fik, Marta, Kultura polska po Jatcie. Kronika lat 1944-1981, London: Aneks, 1989.

Filipowicz, Stanisław, Mit i spektakl władzy, Warszawa: PWN, 1988.

Fitzpatrick, Sheila, Introduction, in Sheila Fitzpatrick (ed.), Stalinism: New Directions, London: Routledge, 2000.

Forecki, Piotr, Reconstructing Memory: The Holocaust in Polish Public Debates, Frankfurt am Main: Peter Lang, 2013.

Frei, Norbert, Adenauer's Germany and the Nazi Past: The Politics of Amnesty and Integration, New York: Columbia University Press, 2002. 
Friedrich, Carl J., i Zbigniew Brzeziński, Totalitarian Dictatorship and Autocracy, Cambridge, MA: Harvard University Press, 1956.

Friszke, Andrzej, 'Przystosowanie i opór. Rozważania nad postawami społecznymi 1956-1970', in Tomasz Szarota (ed.), Komunizm. Ideologia, system, ludzie, Warszawa: Neriton-IH PAN, 2001.

Frontczak, Kazimierz, Siły zbrojne Polski Ludowej. Przejście na stopę pokojowa 1945-1947, Warszawa: MON, 1974.

Furet, François, Le Passé d'une illusion. Essai sur l'idée communiste au XX siècle, Paris: Éditions Robert Laffont, 1995.

Garagozov, Rauf, Metamorfozy kollektivnoi pamiati v Rossii $i$ na tsentral'nom Kavkaze, Baku: Nurlan Publishers, 2005.

Gellner, Ernest, Nations and Nationalism, Ithaca, N.Y: Cornell University Press, 1983.

Gentile, Emilio, The Sacralization of Politics in Fascist Italy, transl. Keith Botsford, Cambridge, MA: Harvard University Press, 1996.

Gillis, John R., 'Memory and Identity: the History of a Relationship', in John R.

Gillis (ed.), Commemorations: the Politcs of Identity, Princeton: Princeton University Press, 1995.

Gleason, Abbott, Totalitarianism: The Inner History of the Cold War, Oxford: Oxford University Press, 1995.

Głowiński, Michał et al., Stosowność i forma. Jak opowiadać o Zagładzie?, Kraków: Universitas, 2005.

Gmitruk, Janusz, Piotr Matusak and Witold Wojdyło, Bataliony Chłopskie, Warszawa: MON, 1987.

Gniazdowski, Mateusz, ' $\mathrm{Zu}$ den Menschenverlusten, die Polen während des Zweiten Weltkrieges von den Deutschen zugefügt wurden. Eine Geschichte von Forschungen und Schätzungen', Historie. Jahrbuch des Zentrums für Historische Forschung Berlin der Polnischen Akademie der Wissenschaften, $1(2007 / 2008)$.

Goeken-Haidl, Ulrike, Der Weg zurück. Die Repatriierung sowjetischer Zwangsarbeiter während und nach dem Zweiten Weltkrieg, Essen: Klartext Verlag, 2006.

Goldhagen, Daniel, Hitler's Willing Executioners, New York: Random House, 1996.

Gontarczyk, Piotr, Polska Partia Robotnicza. Droga do władzy 1941-1944, Warszawa: Fronda, 2013.

Góralewski, Mieczysław and Tadeusz Kamiński, Organizacje kombatanckie i spoleczno-obronne w stużbie Ludowej Ojczyzny, 1945-1969, Warszawa: MON, 1977.

Górski, Jan, Drugie narodziny miasta. Warszawa 1945, Warszawa: PIW, 1976. 
Grabski, Artur, Żydowski ruch kombatancki w Polsce w latach 1944-1949, Warszawa: Trio, 2002.

Gross, Jan T., 'Geneza społeczna demokracji ludowych. O konsekwencjach II wojny światowej w Europie Środkowej', in Tomasz Szarota (ed.), Komunizm. Ideologia, system, ludzie, Warszawa: Neriton, 2001.

Gross, Jan T., Fear: Anti-Semitism in Poland after Auschwitz, Princeton: Pronceton University Press, 2006.

Grunberger, Richard, A Social History of the Third Reich, London: Weidenfeld \& Nicolson, 1971.

Grzelak, Czesław, Henryk Stańczyk and Stefan Zwoliński, Armia Berlinga $i$ Żymierskiego. Wojsko Polskie na froncie wschodnim, Warszawa: Neriton, 2002.

Grzesiuk-Olszewska, Irena, Polska rzeźba pomnikowa w latach 1945-1995, Warszawa: Neriton, 1995.

Haggith, Tobby and Joanna Newman (eds), Holocaust and the Moving Image: Representations in Film and Television since 1933, London: Wallflower, 2005. Halbwachs, Maurice, La Mémoire collective, Gérard Namer (ed.), Paris: Albin Michel, 1997.

Halbwachs, Maurice, Les Cadres sociaux de la mémoire, Paris: Félix Alcan, 1925. Haltof, Marek, Polish Film and the Holocaust, Oxford-New York: Berghahn Books, 2012.

Hatch, Mary Jo, Organization Theory: Modern, Symbolic, and Postmodern Perspectives, Oxford: Oxford University Press, 1997.

Herf, Jeffrey, Divided Memory: The Nazi Past in the Two Germanies, Cambridge, MA: Harvard University Press, 1997.

Hobsbawm, Eric J., Nations and Nationalism since 1788: Programme, Myth, Reality, Cambridge: Cambridge University Press, 1990.

Holzer, Jerzy, 'Uraz, nacjonalizm, manipulacja. Kwestia niemiecka w komunistycznej Polsce', Rocznik Polsko-Niemiecki 1 (1992).

Huener, Jonathan, Auschwitz, Poland, and the Politics of Commemoration: 19451978, Athens: Ohio University Press, 2004.

Hutton, Patrick H., History as an Art of Memory, Hanover: University Press of New England, 1993.

Irwin-Zarecka, Iwona, Neutralizing Memory. The Jew in Contemporary Poland, New Brunswick, NJ: Transaction Publishers, 1989.

Jabłonowski, Marek, Polityczne aspekty ruchu bylych wojskowych w Polsce, 1918-1939, Warszawa: COMSNP, 1989.

Jabłonowski, Marek, Sen o potędze Polski. Z dziejów ruchu byłych wojskowych w II Rzeczpospolitej 1918-1939, Olsztyn: Ośrodek badań im. Wojciecha Kętrzyńskiego w Olsztynie, 1998. 
Janion, Maria, 'Nie-boska komedia - skażone arcydzieło', Gazeta Wyborcza 29 March 2008.

Janion, Maria, Płacz generała. Eseje o wojnie, Warszawa: Wydawnictwo Sic!, 1998.

Jarosz, Anna Barbara, Marzec w prasie, in Marcin Kula, Piotr Osęka and Marcin Zaremba (eds), Marzec 1968. Trzydzieści lat później, Warszawa: PWN, 1998. Jarząbek, Marcin, 'The Victors of a War That Was Not Theirs: First-World-WarVeterans in the Second Republic of Poland and Their European Peers', Acta Poloniae Historica 1, 111 (2015).

Jarząbek, Wanda, 'Władze Polskiej Rzeczpospolitej Ludowej wobec problemu reparacji i odszkodowań od Republiki Federalnej Niemiec 1953-1989', Dzieje Najnowsze 2, 37 (2005).

Jedlicki, Witold, Klub Krzywego Koła, Warszawa: Wydawnictwo GO „Solidarni”, 1989.

Judt, Tony, 'The Past Is Another Country: Myth and Memory in Postwar Europe', Daedalus 121, 4 (1992).

Junes, Tom, Student Politics in Communist Poland: Generations of Consent and Dissent, Lanham: Lexington Books, 2015.

Kaczmarek, Ryszard, Polacy w Wehrmachcie, Kraków: Wydawnictwo Literackie, 2010.

Kajetanowicz, Jerzy, Polskie wojska ladowe w latach 1945-1960. Skład bojowy, struktury organizacyjne i uzbrojenie, Wrocław: Wyższa Szkoła Oficerska im. Tadeusza Kościuszki, 2002.

Kansteiner, Wulf, In Pursuit of German Memory: History, Television, and Politics After Auschwitz, Athens, Ohio: Ohio University Press, 2006.

Kapralski, Sławomir, 'Oświęcim: konflikt pamięci czy kryzys tożsamości?', Przeglad Socjologiczny 2, 49 (2000).

Kardela, Piotr, Stowarzyszenie Polskich Kombatantów w Stanach Zjednoczonych w latach 1953-1990, Olsztyn: IPN, 2015.

Karge, Heike, Steinerne Erinnerung - versteinerte Erinnerung? Kriegsgedenken in Jugoslawien (1947-1970), Wiesbaden: Harrasowitz Verlag, 2010.

Karłowicz, Jan, Adam Kryński and Władysław Niedźwiecki (eds), Słownik języka polskiego, Warszawa: Kasa im. Mianowskiego, 1902.

Kaźmierska, Kaja, Doświadczenia wojenne Polaków a ksztattowanie tożsamości etnicznej. Analiza narrracji kresowych, Warszawa: IFIS PAN, 1999.

Kendall, R. Phillips, 'Introduction' in Kendall R. Phillips (ed.), Framing Public Memory, Tuscaloosa, AL: University of Alabama Press, 2004.

Kenney, Padraic, Rebuilding Poland. Workers and Communism, Ithaca: Cornell University Press, 1997. 
Kersten, Krystyna, 'Osadnictwo wojskowe w 1945 roku. Próba charakterystyki', Przeglad Historyczny 4, 55 (1964).

Kersten, Krystyna, Polacy, Żydzi, Komunizm. Anatomia pótprawd, 1939-1968, Warszawa: Niezależna Oficyna Wydawnicza, 1992.

Kersten, Krystyna, The Establishment of Communist Rule in Poland, 1943-1948, Stanford: Stanford University Press, 1991.

Kisielewicz, Danuta, Oficerowie polscy w niewoli niemieckiej w czasie II wojny światowej, Opole: Centralne Muzeum Jeńców Wojennych w ŁambinowicachOpolu, 1998.

Kiwerska, Jadwiga, W atmosferze wrogości (1945-1970), in Anna Wolf-Powęska (ed.) Polacy wobec Niemców. Z dziejów kultury politycznej Polski 1945-1989, Poznań: Instytut Zachodni, 1993.

Knigge, Volkhard, Instead of a Foreword: the Case History of an Exhibition, in Buchenwald Concentration Camp 1937-1945: A Guide to the Permanent Historical Exhibition, Göttingen: Wallstein Verlag, 2004.

Kolakowski, Leszek, Main Currents of Marxism, transl. P.L. Falla, vol. 1, Oxford: Oxford University Press, 1981.

Komorowski, Krzysztof, Polityka i walka. Konspiracja zbrojna ruchunarodowego, 1939-1945, Warszawa: Rytm, 2000.

Kopp, Kristin and Joanna Niżyńska, Germany, Poland and Postmemorial Relations: In Search of a Livable Past, New York: Palgrave Macmillan, 2012. Kosmala, Beate, Die ,jüdische Frage” als politisches Instrument in der Volksrepublik Polen, in Beate Kosmala (ed.), Die Vertreibung der Juden aus Polen 1968. Antisemitismus und politisches Kalkül, Berlin: Metropol, 2000.

Kotkin, Stephen, Magnetic Mountain. Stalinism as a Civilization, Berkeley: University of California Press, 1995.

Kozłowski, Eligiusz, 'Armia' in Witold Kula and Janina Leskiewiczowa (eds) Przemiany społeczne w Królestwie Polskim 1815-1864, Wrocław: Ossolineum, 1979.

Król, Marcin, 'Ewolucja, restauracja, amnezja. O pamięci w czasach postkomunistycznych', Res Publica 5, 43 (1991).

Kucia, Marek, Auschwitzjakofakt społeczny. Historia, wspótczesność iświadomość społeczna KL Auschwitz w Polsce, Kraków: Universitas, 2005.

Kula, Marcin, Narodowe i rewolucyjne, London: Aneks, 1991.

Kula, Marcin, Religiopodobny komunizm, Kraków: Nomos, 2003.

Kunicki, Mikołaj S., Between the Brown and the Red: Nationalism, Catholicism, and Communism in Twentieth Century Poland: The Politics of Bolestaw Piasecki, Athens, Ohio: Ohio University Press, 2012. 
Kurczewska, Joanna, 'Nacjonalizm i rzeczywistość mityczna', in Edmund Mokrzycki, Maria Ofierska and Jerzy Szacki (eds), O społeczeństwie i teorii społecznej. Księga poświęcona pamięci Stanisława Ossowskiego, Warszawa: PWN, 1985.

Kwiatkowski, Piotr T., Lech Nijakowski, Barbara Szacka and Andrzej Szpociński, Między codziennościq a wielka historiq. Druga wojna światowa w pamięci zbiorowej społeczeństwa polskiego, Gdańsk-Warszawa: Muzeum II Wojny Światowej-Scholar, 2010.

Lagrou Pieter, The Legacy of Nazi-occupation: Patriotic Memory and National Recovery in Western Europe, 1945-1965, Cambridge: Cambridge University Press, 2000.

Lane, Christel, 'From Ideology to Political Religion: Recent Developments in Soviet Beliefs and Rituals in the Patriotic Tradition', in Claes Arvidsson and Lars E. Blomqvist (eds) Symbols of Power: The Esthetics of Political Legtimation in the Soviet Union and Eastern Europe, Stockholm: Almqist and Wiksell International, 1987.

Langner, Tadeusz, 'Organizacja i przebieg osadnictwa wojskowego w powiatach słubickim i sulęcińskim w latach 1945-1946' in Przeglad Zachodni 1-2, 23 (1967).

Laquer, Thomas W., Memory and Naming in the Great War, in John R. Gillis (ed.), Commemorations: the Politics of Identity, Princeton: Princeton University Press, 1995.

Lastouski, Aliaksei, 'Historical Memory as a Factor of Strengthening Belarusian National Identity' in Vjeran Pavlaković, Davor Pauković and Višeslav Raos (eds), Confronting the Past: European Experiences, Zagreb: Political Science Research Centre, 2012.

Leggewie, Claus, Anne Lang, Der Kampf um die europäische Erinnerung. Ein Schlachtfeld wird besichtigt, München: C. H. Beck Verlag, 2011.

Lendvai, Paul, Anti-Semitism without Jews: Communist Eastern Europe, Garden City, NY: Doubleday, 1971.

Lesiakowski, Krzysztof, "’Partyzanci” wobec dziejów Polski w czasie II wojny światowej', in Sławomir M. Nowinowski, Jan Pomorski and Rafał Stobiecki (eds), Pamięć i polityka historyczna. Doświadczenia Polski i jej sąsiadów, Łódź: IPN, 2008.

Lesiakowski, Krzysztof, Mieczysław Moczar „Mietek”. Biografia polityczna, Warszawa: Rytm, 1998.

Levy, Daniel and Natan Sznaider, Human Rights and Memory, University Park, PA: Pennsylvania State University Press, 2010.

Levy, Daniel and Natan Sznaider, The Holocaust and Memory in the Global Age, Philadelphia: Temple University Press, 2006. 
Lim, Jie-Hyun, 'Victimhood Nationalism in Contested Memories: National Mourning and Global Accountability', in Aleida Assmann and Sebastian Conrad (eds), Memory in a Global Age: Discourses, Practices and Trajectories, Basingstoke: Palgrave Macmillan, 2010.

Łuczak, Czesław, Polacy w okupowanych Niemczech, Poznań: PSO, 1993.

Machcewicz, Paweł and Krzysztof Persak (eds), Wokót Jedwabnego, vols 1, 2, Warszawa: IPN, 2002.

Machcewicz, Paweł, 'Zmiana czy kontynuacja? Polska przed i po Październiku' 56?', in Dariusz Stola and Marcin Zaremba (eds), PRL. Trwanie i zmiana, Warszawa: IH UW-Wydawnictwo WSPiZ im. L. Koźmińskiego, 2003.

Machcewicz, Paweł, Polski rok 1956, Warszawa: Mówią Wieki, 1993.

Madajczyk, Piotr, 'Polska myśl zachodnia w polityce komunistów polskich', Przeglad Zachodni 3, 53 (1997).

Madajczyk, Piotr, 'Die Rolle antideutscher Instrumentalisierungen in Polen, 1944-1989,' in Dieter Bingen, Peter Oliver Loew and Kazimierz Wóycicki (eds), Die Destruktion des Dialogs. Zur innenpolitischen Instrumentalisierung negativer Fremdbilder und Feindbilder, Polen, Tschechien, Deutschland und die Niederlande im Vergleich, 1900-2005, Wiesbaden 2007.

Main, Izabella, Trudneświętowanie. Konflikty wokół obchodów świątpaństwowych i kościelnych w Lublinie (1944-1989), Warszawa: Trio, 2004.

Mamak, Kazimierz, Osadnictwo wojskowe na Ziemi Lubuskiej, Poznań: Wydawnictwo Poznańskie, 1979.

Mann, Michael, The Sources of Social Power: the Rise of Classes and NationStates, 1760-1914, Cambridge: Cambridge University Press, 1993.

Marcuse, Harold, Legacies of Dachau: the Uses and Abuses of a Concentration Camp 1933-2001, Cambridge: Cambridge University Press, 2001.

Mark, James and Robert Gildea, Conclusion: Europe's 1968, in Robert Gildea, James Mark and Annette Warring (eds), Europe's 1968, Oxford: Oxford University Press 2013.

Markiewicz, Tomasz, 'Der Kampfum die Erinnerung. Denkmäler der Heimatarmee in Warschau seit $1945^{\prime}$ in Bernard Chiari in collab. with Jerzy Kochanowski (eds), Die polnische Heimatarmee. Geschichte und Mythos der Armia Krajowa seit dem Zweiten Weltkrieg, München: R. Oldenbourg Verlag, 2003.

Martin, Garret, J. General de Gaulle's Cold War: Challenging American Hegemony, 1963-68, New York: Berghahn Books, 2013.

Materski, Wojciech and Tomasz Szarota (eds), Polska 1939-1945. Straty osobowe $i$ ofiary represji pod dwiema okupacjami, Warszawa: Instytut Pamięci Narodowej, 2009.

Mazur, Zbigniew (ed.), Wokół niemieckiego dziedzictwa kulturowego na Ziemiach Zachodnich i Pótnocnych, Poznań: Instytut Zachodni, 1997. 
Mazur, Zbigniew (ed.), Wspólne dziedzictwo? Ze studiów nad stosunkiem do spuścizny kulturowej na Ziemiach Zachodnich i Pótnocnych, Poznań: Instytut Zachodni, 2000.

Mazur, Zbigniew, 'Upamiętnianie w latach 1945-1948 ofiar niemieckiej okupacji', Przeglad Zachodni 4, 60 (2004).

Mazur, Zbigniew, Obraz Niemiec $w$ polskich podręcznikach szkolnych do nauczania historii 1945-1989, Instytut Zachodni, Poznań 1995.

Melchior, Małgorzata, Zagłada a tożsamość. Polscy Żydzi ocaleni „,na aryjskich papierach”. Analiza doświadczenia biograficznego, Warszawa: IFIS PAN, 2004.

Merridale, Catherine, Ivan's War: Life and Death in the Red Army, 1939-1945, New York: Metropolitan Books, 2006.

Michlic, Joanna and Małgorzata Melchior, 'The Memory of the Holocaust in Post-1989: Renewal-Its Accomplishments and Its Powerlessness' in JohnPaul Himka and Joanna Michlic (eds), Bringing the Dark Past to Light: The Reception of the Holocaust in Postcommunist Europe, Lincoln: University of Nebraska Press, 2013.

Middleton, David, Derek Edwards, 'Introduction' in David Middleton, Derek Edwards (eds), Collective Remembering, London: Sage, 1990.

Mierzwa, Jan Z., Kombatancki Kraków 1918-1938, Kraków: Fundacja Rozwoju Samorządności i Prasy Lokalnej, 2002.

Mircea Eliade, Mythes, rêves et mystères, Paris: Gallimard, 1957.

Misztal, Barbara, Theories of Social Remembering, Philadelphia: Open University Press, 2003.

Mosse, George L., Fallen Soldiers: Reshaping the Memory of the World Wars, Oxford: Oxford University Press, 1990.

Mosse, George L., The Crisis of German Ideology: Intellectual Origins of the Third Reich, New York: Grosset \& Dunlap, 1964.

Motyka, Grzegorz and Rafał Wnuk, Pany i rezuny. Wspótpraca AK-WiN i UPA 1945-1947, Warszawa: Volumen, 1997.

Najorek, Winicjusz, Perspektywy pluralizmu w upaństwowionym społeczeństwie. Ocena sytuacji na podstawie polskich kryzysów, Warszawa: ISP PAN, 1994.

Nazarewicz, Ryszard, Armii Ludowej dramaty i dylematy, Warszawa: Oficyna Drukarska, 2000.

Neitzel, Sonke and Harald Welzer, Soldiers: German POWs on Fighting, Killing, and Dying, New York: Knopf Doubleday Publishing Group, 2012.

Neumann-Thein, Philipp, Parteidisziplin und Eigenwilligkeit. Das Internationale Komitee Buchenwald-Dora und Kommandos, Göttingen: Wallstein Verlag, 2014.

Nora, Pierre (ed.), Les Lieux de mémoire, Paris: Gallimard, 1984-1992, vols 1-7. 
Norbert Elias, The Germans: Power Struggles and the Development of Habitus in the 19th and 20th Centuries, Cambridge: Cambridge University Press, 1996. Noszczak, Bartłomiej, Sacrum czy profanum? Spór o istotę obchodów Milenium polskiego, Warszawa: Towarzystwo Naukowe Warszawskie, 2002.

Ochman, Ewa, Post-Communist Poland - Contested Pasts and Future Identities, London: Routledge, 2013.

Ogrodowczyk, Arkadiusz, Nad Odra i Battykiem. Osadnictwo wojskowe na zachodnich i pótnocnych ziemiach Polski po drugiej wojnie światowej, Warszawa: MON, 1979

Olick, Jeffery K., The Politics of Regret: On Collective Memory and Historical Responsibility, New York: Routledge, 2007.

Olick, Jeffrey K. and Joyce Robbins, 'Social Memory Studies: From "Collective Memomry" to the Historical Sociology of Mnemonic Practices', Annual Review of Sociology 24 (1998).

Osęka, Piotr, Encyklopedyści, Magazyn, a supplement to Gazeta Wyborcza, 5-7 March 1998

Osęka, Piotr, Marcin Zaremba, 'Wojna po wojnie - czyli polskie reperkusje wojny sześciodniowej', in Polska 1944/45-1989. Studia i Materiały, 4 (1999).

Osęka, Piotr, Rytuaty stalinizmu. Oficjalne święta i uroczystości rocznicowe w Polsce 1944-1956, Warszawa: Trio, 2007.

Osęka, Piotr, Syjoniści, inspiratorzy, wichrzyciele. Obraz wroga w propagandzie marca 1968, Warszawa: ŻIH, 1999.

Osękowski, Czesław, Pionierzy w mundurach na Ziemi Lubuskiej, Zielona Góra: Lubuski Komitet Upowszechniania Prasy, 1985.

Pałka, Jarosław, Machteld Venken and Krzysztof Marcin Zalewski, Żolnierze generała Maczka. Doświadczenie i pamięć wojny, Gdańsk: Muzeum II Wojny Światowej, 2013.

Paulsson, Gunnar S., Secret City: The Hidden Jews of Warsaw, 1940-1945, New Haven: Yale University Press, 2002.

Persak, Krzysztof, Sprawa Henryka Hollanda, Warszawa: IPN, 2006.

Polian, Pavel, Zhertvy dvukh diktatur: Zhizn', trud, unizhenie i smert'sovetskikh voennoplennykh $i$ ostarbeiterov na chuzhbine $i$ rodine, Moskva: Rosspen, 2002.

Porter, Brian, When Nationalism Began to Hate: Imagining Modern Politics in Nineteenth-century Poland, Oxford: Oxford University Press, 2000.

Prażmowska, Anita, Civil War in Poland 1942-1948, Basingstoke: Palgrave Macmillan, 2004.

Prokop, Jan, Wyobraźnia pod nadzorem. Z dziejów literatury i polityki w PRL, Kraków: Viridis, 1994. 
Prost, Antoine, Les Anciens Combattants et la société française, 1914-1930, vols 1-3, Paris: Presses de la Fondation Nationale des Sciences Politiques, 1977. Radomski, Jerzy, Losy formacji polskich na Zachodzie po zakończeniu wojny, in Witold Biegański (ed.), Walki formacji polskich na Zachodzie, 1939-1945, Warszawa: MON, 1981.

Rausing, Sigrid, History, Memory, and Identity in Post-Soviet Estonia, Oxford: Oxford University Press, 2004

Rechowicz, Henryk, Powstańcy ślascy w Polsce Ludowej 1945-1949, Katowice: Śląski Instytut Naukowy, 1970.

Rechowicz, Henryk, Zwiazek Weteranów Powstań Śląskich. 1945-1949, Katowice: Śląski Instytut Naukowy, 1966.

Rokuszewska-Pawełek, Alicja, Chaos i przymus. Trajektorie wojenne Polaków - analiza biograficzna, Łódź: Wydawnictwo Uniwersytetu Łódzkiego, 2002. Romijn, Peter, "'Restoration of Confidence": The Purge of Local Government in the Netherlands As a Problem of Postwar Reconstruction', in István Deák, Jan T. Gross, and Tony Judt (eds), The Politics of Retribution in Europe: World War II and its Aftermath, Princeton: Princeton University Press, 2000.

Rousso, Henry, The Vichy Syndrome: History and Memory in France since 1944, transl. A. Goldhammer, Cambridge, MA: Harvard University Press, 1991.

Ruchniewicz, Krzysztof, Polskie zabiegi o odszkodowania niemieckie w latach 1944/45-1975, Wrocław: Wydawnictwo Uniwersytetu Wrocławskiego, 2007.

Ruchniewicz, Małgorzata, Repatriacja ludności polskiej z ZSRR w latach 195559, Warszawa: Volumen, 2000.

Rusiniak, Martyna, 'Treblinka - Eldorado Podlasia?', Kwartalnik Historii Żydów 2, 218 (2006).

Rutkowski, Tadeusz P., Adam Bromberg i "encyklopedyści”. Kartka z dziejów inteligencji w PRL, Warszawa: Wydawnictwa Uniwersytetu Warszawskiego, 2010.

Rykowski, Zbysław and Wiesław Władyka, Polska próba. Październik’ 56, Kraków: Wydawnictwo Literackie, 1989.

Santis, Ramona S. 'Zwischen "Sklaverei" und "Verrat". Überlegungen zum Opferbild von Zwangsarbeiterinnen und Kriegsgefangenen in der Sowjetunion zwischen 1941 und 1991' in Ulf Brunnbauer, Andreas Helmedach and Stefan Troebst (eds), Schnittstellen: Gesellschaft, Nation, Konflikt und Erinnerung in Südosteuropa, München: Oldenbourg Verlag, 2007.

Sawicki, Jacek Z., Bitwa o prawdę. Historia zmagań o pamięć Powstania Warszawskiego 1944-1989, Warszawa: DiG, 2005.

Schöpflin, George, 'The Functions of Myth and a Taxonomy of Myths', in Geoffrey Hosking and George Schöpflin (eds), Myths and Nationhood, New York: Routledge, 1997. 
Sherman, Daniel J., 'Art, Commerce, and the Production of Memory in France after World War I', in John R. Gillis (ed.), Commemorations: the Politics of Identity, Princeton: Princeton University Press, 1995.

Siegel, Mona L., The Moral Disarmament of France: Education, Pacifism, and Patriotism, 1914-1940, Cambridge: Cambridge University Press, 2011.

Skalska, Agnieszka, Obraz wroga w antysemickich rysunkach prasowych Marca '68, Warszawa: Narodowe Centrum Kultury, 2007.

Skocpol, Theda, Protecting Soldiers and Mothers. The Political Origins of Social Policy in the United States, Cambridge, MA: Harvard University Press, 1992.

Skoczylas, Michał, Wybory do Sejmu Ustawodawczego z 19 stycznia 1947 roku w świetle skarg ludności, Warszawa: Trio, 2003.

Snyder, Timothy, Bloodlands: Europe between Hitler and Stalin, New York: Basic Books, 2010.

Sołtysiak, Dominik, 'Podstawy prawne i implementacja odszkodowań niemieckich dla polskich ofiar eksperymentów pseudomedycznych w latach 1945-1989', in Witold M. Góralski (ed.), Problem reparacji, odszkodowań $i$ świadczeń w stosunkach polsko-niemieckich 1944-2004, vol. 1 Studia, Warszawa: PISM, 2004.

Sommer, Łukasz and Joanna Wawrzyniak, 'The Ukrainian Crisis in the Polish Media', in The Ukrainian Crisis in the European Media and the Public Sphere “Cultures of History" Forum, Version: 1.0, 02.06.2014, URL: http://www. imre-kertesz-kolleg.uni-jena.de/index.php?id=578.

Staniszkis, Jadwiga, Ontologia socjalizmu, Warszawa: In Plus, 1989.

Staniszkis, Jadwiga, Poland's Self-Limiting Revolution, Princeton: Princeton University Press, 1984.

Steinlauf, Michael C., Bondage to the Dead. Poland and the Memory of the Holocaust, Syracuse, NY: Syracuse University Press, 1997.

Stengel, Katharina, 'Competition for Scant Funds Jewish, Polish, and Communist Prisoners of Auschwitz in the Negotiations for the Wollheim Agreement', Frankfurt am Main: Norbert Wollheim Memorial, 2010.

Stobniak-Smogorzewska, Janina, Kresowe osadnictwo wojskowe 1920-1945, Warszawa: ISP PAN, 2003.

Stola, Dariusz, 'Poland's Institute of National Remembrance: Ministry of Memory' in Alexei Miller and Maria Lipman (eds), Convolutions of Historical Politics, Budapest: CEU Press, 2012.

Stola, Dariusz, Antyżydowski nurt Marca 1968, in Konrad Rokicki and Sławomir Stępień (eds), Oblicza Marca 1968, Warszawa: IPN, 2004.

Stola, Dariusz, Kampania antysyjonistyczna w Polsce 1967-1968, Warszawa: ISP PAN, 2000. 
Styś, Leon, Osadnictwo wojskowe na Dolnym Śląsk w latach 1945-1948,

Wrocław: Dolnośląskie Towarzystwo Społeczno-Kulturalne, 1968.

Szacka, Barbara, Czas przeszty, pamięć, mit, Warszawa: Scholar, 2006.

Szaynok, Bożena, Z historia i Moskwa w tle. Polska a Izrael 1944-1968, Warszawa:

IPN, 2007.

Szpociński, Andrzej, 'Społeczne funkcjonowanie symboli', in Teresa Kostyrko

(ed.), Symbol i poznanie. W poszukiwaniu koncepcji integrujacej, Warszawa:

PWN, 1987.

Szpociński, Andrzej, Przemiany obrazu przeszłości Polski. Analiza słuchowisk historycznych dla szkót podstawowych, Warszawa: IS UW, 1989.

Szymczak, Mieczysław (ed.), Stownik języka polskiego vol.1, Warszawa: PWN, 1978.

Tarkowska, Elżbieta, Czas w społeczeństwie. Problemy, tradycje, kierunki badań, Warszawa: IFiS PAN, 1987.

Tarkowski, Jacek, Patroni i klienci, Warszawa: ISP PAN, 1994.

Traba, Robert, 'Symbole pamięci. II wojna światowa w świadomości zbiorowej Polaków. Szkic do tematu', Przegląd Zachodni 1, 56 (2000).

Troebst, Stefan, 'Halecki Revisited: Europe's Conflicting Cultures of Remembrance', in Małgorzata Pakier and Bo Stråth (eds), A European Memory? Contested Histories and Politics of Remembrance, Oxford-New York: Berghahn Books, 2010.

Tumarkin, Nina, 'The Great Patriotic War as Myth and Memory', European Review 4, 11 (2003).

Tych, Feliks, 'Kilka uwag o Marcu 1968 ' in Marcin Kula, Piotr Osęka and Marcin Zaremba (eds), Marzec 1968. Trzydzieści lat później, Warszawa: PWN, 1998. Tyszka, Krzysztof, Nacjonalizm w komunizmie. Ideologia narodowa w Zwiazku Radzieckim i Polsce Ludowej, Warszawa: IFIS PAN, 2004.

Tyszkiewicz, Jakub, 'Propaganda ziem odzyskanych w prasie Polskiej Partii Robotniczej w latach 1945-1948', Przeglad Zachodni 4, 51 (1995).

Venken, Machteld, Straddling the Iron Curtain? Immigrants, Immigrant Organisations, War Memories, Frankfurt am Main: Peter Lang, 2011.

Verdery, Katherine, National Ideology under Socialism. Identity and Cultural Politics in Ceausescu's Romania, Berkeley: University of California Press, 1991.

Wawrzyniak, Joanna and Małgorzata Pakier, 'Memory Studies in Eastern Europe: Key Issues and Future Perspectives', Polish Sociological Review 183, 3 (2013). Wawrzyniak, Joanna and Zofia Wóycicka, 'Jonathan Huener, Auschwitz, Poland, and the Politics of Commemoration, 1945-1979' [review], Kwartalnik Historii Żydów 2, 218 (2006). 
Wawrzyniak, Joanna, ZBoWiD i pamięć drugiej wojny światowej. 1949-1969, Warszawa: Trio, 2009.

Weiner, Amir, Making Sense of War. The Second World War and the Fate of the Bolshevik Revolution, Princeton: Princeton University Press, 2001.

Welch, Steven R. 'Commemorating "Heroes of a Special Kind": Deserter Monuments in Germany', Journal of Contemporary History 47, 2 (2012).

Welzer, Harald, Sabine Moller and Karoline Tschuggnall, 'Opa war kein Nazi': Nationalsozialismus und Holocaust im Familiengedächtnis, Frankfurt am Main: Fischer Verlag, 2002.

Welzer, Harald, Täter. Wie aus ganz normalen Menschen Massenmörder werden, Frankfurt am Main: Fischer Verlag, 2005.

Wertsch, James K., Voices of Collective Remembering, Cambridge: Cambridge University Press, 2002.

Wertsch, James V, 'A Clash of Deep Memories', Profession (2008).

Wierzbicki, Marek, Związek Młodzieży Polskiej i jego członkowie, Warszawa: Trio, 2006.

Wigura, Karolina, 'Alternative Historical Narrative: "Polish Bishops' Appeal to Their German Colleagues" of 18 November 1965', East European Politics \& Societies 3, 27 (2013).

Wilke, Karsten, Die 'Hilfsgemeinschaft auf Gegenseitigkeit'(HIAG) 1950-1990. Veteranen der Waffen-SS in der Bundesrepublik, Paderborn: Ferdinand Schöningh Verlag, 2011.

Winter, Jay and Emmanuel Sivan (eds), 'Setting the Framework', in War and Remembrance in the Twentieth Century, Cambridge: Cambridge University Press, 1990.

Winter, Jay, 'Forms of Kinships and Remembrance in the Aftermath of the Great War', in Winter Jay and Emmanuel Sivan (eds), War and Remembrance in the Twentieth Century, Cambridge: Cambridge University Press, 1990.

Wnuk, Rafał, Lubelski Okręg AK-DSZ i WiN. 1944-1947, Warszawa: Volumen, 2000.

Wolf-Powęska, Anna (ed.), Polacy wobec Niemców. Z dziejów kultury politycznej Polski 1945-1989, Poznań: Instytut Zachodni, 1993.

Wóycicka, Zofia, 'Niezrealizowany projekt upamiętnienia terenu byłego obozu Zagłady w Treblince z 1947 roku. Próba analizy ikonograficznej', in Michał Glowiński et al. (eds), Stosowność i forma. Jak opowiadać o Zagładzie? Kraków: Universitas, 2005.

Wóycicka, Zofia, 'Zur Internationalität der Gedenkkultur: Die Gedenkstätte Auschwitz-Birkenau im Spannungsfeld zwischen Ost und West 1954-1978', Archiv für Sozialgeschichte 45 (2005). 
Wóycicka, Zofia, Arrested Mourning: Memory of the Nazi Camps in Poland 1944-1950, Frankfurt am Main: Peter Lang Verlag, 2014.

Wóycicka, Zofia, 'Die Kanalisierung des Gedenkens: Die Gedenkstätte Auschwitz-Birkenau in den Jahren 1945-1955' in Stefan Troebst and Krzysztof Ruchniewicz (eds), Diktaturenbewältigung und nationale Selbstvergewisserung - Geschichtskulturen in Polen und Spanien im Vergleich, Wrocław: Centrum Studiów Niemieckich i Europejskich im. Willy Brandta, 2004.

Wróbel, Piotr, Droga powrotna. Niemiecki prawicowy ruch kombatancki po I wojnie światowej, Warszawa: Książka i Wiedza, 1989.

Wydra, Harald, 'Dynamics of Generational Memory: Understanding the EastWest Divide', in Eric Langenbacher, Bill Niven, and Ruth Wittlinger (eds), Dynamics of Memory and Identity in Contemporary Europe, New YorkOxford: Berghahn Books, 2013.

Wyka, Kazimierz, Życie na niby, Kraków: Wydawnictwo Literackie, 1984.

Xenakis, Christopher I., What Happened to the Soviet Union? How and Why American Sovietologists Were Caught by Surprise, Westport, CT: Praeger Publishers, 2002.

Yekelchyk, Serhy, Stalin's Empire of Memory: Russian-Ukrainian Relations in the Soviet Historical Imagination, Toronto: University of Toronto Press, 2004.

Young, James, The Texture of Memory. Holocaust Memorials and Meaning, New Haven: Yale University Press, 1993.

Zamojski, Jan. E., Interbrygadziści Republiki Hiszpańskiej - Po klęsce... Losy Polaków, in Elda González Martinez and Małgorzata Nalewajko (eds), Hiszpania-Polska: spotkania, Warszawa: Neriton, 2003.

Zamponi, Simonetta Falasca, 'Of Storytellers and Master Narratives: Modernity, Memory, and History in Fascist Italy', Social Science History. Special Issue: Memory and the Nation, 4, 22 (1998).

Zaremba, Marcin, Komunizm, legitymizacja, nacjonalizm. Nacjonalistyczna legitymizacja władzy komunistycznej w Polsce, Warszawa: Trio, 2001.

Zaremba, Marcin, Wielka Trwoga. Polska 1944-1947. Ludowa reakcja na kryzys, Kraków: Znak, 2012.

Żaryn, Jan, "Księża patrioci" - geneza powstawania formacji duchownych katolickich, in Polska 1944/45-1989', Studia i materiaty, 1, 1 (1995).

Żaryn, Jan, Kościól a władza w Polsce (1945-1950), Warszawa: DiG, 1997.

Zessin-Jurek, Lidia, 'The Rise of and East European Community of Memory? On Lobbying for the Gulag Memory via Brussels', in Małgorzata Pakier and Joanna Wawrzyniak (eds), Memory and Change in Europe: Eastern Perspectives, New York-Oxford: Berghahn Books, forthcoming.

Zgółkowa, Halina (ed.), Praktyczny słownik współczesnej polszczyzny, Poznań: Wydawnictwo Kurpisz, 1998. 
Żurek, Jacek, Ruch 'księży patriotów'w województwie katowickim w latach 1949_ 1956, Warszawa: IPN, 2009.

Zwick, Peter, National Communism, Boulder, Colorado: Westview Press, 1983.

Żychlińska, Monika and Erica Fontana, 'Museal Games and Emotional Truths: Creating Polish National Identity at the Warsaw Rising Museum', East European Societies and Politics, first published on May 11, 2015 as doi:10.1177/0888325414566198.

\section{Unpublished Manuscripts}

Barański, Piotr, Walka z chorobami wenerycznymi w Polsce w latach 1948-1949, MA dissertation, Institute of History, University of Warsaw 2007.

Nowak, Barbara A., Serving Women and the State: The League of Women in Communist Poland, PhD dissertation, Ohio State University 2004.

Stelmach, Andrzej, Historia ZBoWiD, unpublished organizational history of ZBoWiD, Warszawa 1989. 
Joanna Wawrzyniak - 978-3-653-99681-4

Downloaded from PubFactory at 01/11/2019 11:05:35AM

via free access 


\section{Index}

$193914,44,47,51,52,55,62,71,89,108$, $112,119,120,136,165,166,174,182$, 190-92, 208, 227

$194147,136,188$

$194514,19,25,32,44,46,47,49,50,52$, $54,55,59-62,65,68,69,72,86,90,112$, $113,128,147-49,159,166,168,220$

$195614,15,26,38,39,41,44,46,53,101$, $106,118,128,129,130,133-137,139$, $140,142,145,146,148,149,153,154$, $156,157,161,167,177,183,185,190$, $199,213,215,217$

1967 41, 134, 136, 139, 184, 189, 190, 196, 200-03, 205, 208, 220

$1968181,184,190,191,196,201-05,207$, $209,210,221$

$198914,19,48,202,221,222,224,227$

Acton, Norman 139

Adenauer, Konrad 96, 168

AK, see Home Army

AL, see People's Army

Albrecht, Jerzy 77

Alef-Bolkowiak, Gustaw 116

Alster, Antoni 39, 40

Ambroziewicz, Jerzy 137

America(n), see United States of America

Anders, Władysław 47, 112

Anti-Semitism, anti-Semitic 14, 15, 70, 96, $104,119,155,157,171,182,184,185$, 196, 199-203, 205-07, 209, 219

Antonescu, Ion Victor 218

Armia Krajowa, see Home Army

Armia Ludowa, see People's Army

Assmann, Aleida 20

Assmann, Jan 20

Association Nationale des Anciens Combattants de la Résistance, see National Association of Former Resistance Fighters

Association Nationale des Combattants Volontaires de la Résistance, see National Association of Volunteer Resistance Fighters
Association of Persons Persecuted by the Nazi Regime (VVN) 34, 96, 100, 219

Auschwitz see Auschwitz-Birkenau Auschwitz-Birkenau 59, 65, 87, 96, 100, 102-08, 111, 124, 134, 141, 143, 169, 177, 197, 199, 206, 210, 218. See also Oświęcim

Austria(n) 29, 64, 102, 106, 209

Baczko, Bronisław 23

Balicki, Zygmunt 92

Banach, Kazimierz 140, 142, 162, 173, 211

Barcelona 94

Bataliony Chtopskie, see Peasants' Battalions Bauman, Zygmunt 201

Baumritter, Jerzy 204

Bautzen (Budziszyn) 112

$\mathrm{BCh}$, see Peasants' Battalions

Belarus(ian) 32, 54, 71, 78, 115, 225

Belgium 101, 220

Bełżec 65, 199

Bem, Józef 111

Bereza Kartuska 78, 87, 108

Bergson, Henri 20

Berlin 25, 47, 90, 113, 169

Berling, Zygmunt 47, 188

Białystok 197

Bierut, Bolesław 55, 87, 90, 92, 98, 99, 105, $132,135,139$

Biłgoraj 151, 152

Birkenau, see Auschwitz-Birkenau

Bombay 94

Bonn 101, 105

Borodziej, Włodzimierz 16

Brezhnev, Leonid 33, 182

Brussels 101, 139

Brycht, Andrzej 193

Brzezinka, see Auschwitz-Birkenau

Brzeziński, Zbigniew 34

Brzostek, Błażej 16

Buchenwald 87, 102, 103, 106, 108, 109

Budapest 16, 136

Budziszyn, see Bautzen 
Bulgaria 86, 219, 225

Busse, Ernst 102

Bychawa 151, 155, 179

Bytom 70

Camp(s) 13-15, 22, 34, 38, 40, 41, 47, 49, $53,58-60,63-65,68,71,77-79,85,87$, 94, 96, 99-111, 113-17, 120, 131, 141, 143-46, 166, 167, 169-72, 175, 182, 197, 199, 207, 210, 211, 216, 219

Castellati, Maria 116

Catholic Church 24, 46, 93, 105, 196, 197, 215, 219

Chęciński, Sylwester 193, 194

Chełchowski, Hilary 185

Chełmno 65, 199

Chmielewski, Tadeusz 193

Chu, Winson 17

Cold War 15, 26, 32, 35, 37, 85, 86, 94, 100, 103, 107, 110, 196, 220

Committee of Anti-fascist Resistance Fighters (KdAW) 96, 219

Confédération Nationale des Combattants Volontaires de la Résistance, see National Confederation of Volunteer Resistance Fighters

Confédération Nationale des Prisonniers Politiques, see National Confederation of Political Prisoners

Council for the Protection of Sites of Struggle and Martyrdom 46, 179, 205, 224

Cyrankiewicz, Józef 58, 59, 63, 78, 87, 92, $103,105,107,131,140,146,173,174$, 207

Czarniecki, Stefan 111

Czechoslovakia 86

Czekalski, Stanisław 193

Czerwieński, Bolesław 109

Dąbek, Paweł 156, 166

Dąbrowski, Jarosław 59, 111

Dachau 79, 101, 102, 103, 106, 108, 110

Dayan, Moshe 208

Deutscher Kriegerbund, see German Warrior League 28

Dimitrov, Georgi 98

Dmitrów, Edmund 25
Dobiegniewo 174

Dorfman, Henryk 202

Duszyński, Zygmunt 185

Działdowo 199

Dzierzkowice 151

East Germany, see German Democratic Republic (GDR)

Edele, Mark 33

Eichmann, Adolf 221

European Union (EU) 227

Farge, Yves 95

Fascism, fascist 13, 15, 26, 29, 30, 54, 58, 79, $85,90,93,95,96,97,101-03,107,110$, $112,117,133-35,138,161,174,176$, 185, 207, 210, 213, 214, 215, 216, 219

Federal Republic of Germany (FRG) 102-07, 134, 146, 167, 168-71, 173, 197, 206-08, 219,221

Fédération Internationale des Anciens Prisonniers Politiques, see International Federation of Former Political Prisoners

Fédération Internationale des Résistants, see International Federation of Resistance Fighters

Fédération Internationale Libre des Déportés et Internés de la Résistance, see Free International Federation of Deportees and Internees of the Resistance Fighters

Fédération Mondiale des Anciens Combattants, see World Federation of Former Combatants

Fédération Nationale des Déportés et Internés de la Résistance, see National Federation of Deportees and Internees of the Resistance Movement

Fédération Nationale des Déportés et Internés Résistants et Patriotes, see National Federation of Deported and Imprisoned Resistance Fighters and Patriots

FIAPP, see International Federation of Former Political Prisoners

FILDIR, see Free International Federation of Deportees and Internees of the Resistance Fighters

Finder, Paweł 102, 103 
FIR, see International Federation of Resistance Fighters

First World War 27, 28, 29, 30, 31, 51, 59, 68 FMAC, see World Federation of Former Combatants

Ford, Aleksander 193, 194

Fornalska, Małgorzata 102, 103

France, French 20, 21, 26, 29, 30, 31, 48, 51, $59,71,86,87,95,107,134,189,220$

Frankfurt am Main 134

Free International Federation of Deportees and Internees of the Resistance Fighters (FILDIR) 32, 101, 170

Freedom and Independence (WiN) 39, 40, 44, $48,117,138,139,146-52,154,155,156$, 159,160

French Union of Former Combatants 32

Freud, Sigmund 20

FRG, see Federal Republic of Germany

Friszke, Andrzej 157

Fuksiewicz, Bernard 123

Garncarczyk, Wilhelm 93, 121, 123, 125, 140

Gaulle, Charles de 220

Gdańsk 77, 140, 143, 144, 164, 166

GDR, see German Democratic Republic

German Democratic Republic (GDR) 26, 34, 44, 96, 102, 106, 134, 169, 219

German Warrior League 28

Germany, German 15, 17, 19, 20, 25, 26, 28, $31,32,38,44,45,47-49,52-54,58,59$, 70-76, 78, 85-87, 91, 96, 101, 102, 105, $108,110,113-15,119,134,145,148,160$, 166-70, 173, 174, 176, 184, 196-98, 204, 206, 208, 209, 211, 216, 218. See also Prussia; Weimar Republic; Third Reich; Federal Republic of Germany (FRG); German Democratic Republic (GDR)

Gierek, Edward 217

Gildea, Robert 221

GL, see People's Guard

Gleason, Abbott 37

Gliwice 174

Gołębiewski, Marian 151

Gomułka, Władysław 19, 119, 135, 137, 140, 153, 156, 168, 184, 185, 187, 203, 208
Grabowiec 153, 157

Grabski, August 70

Great Britain, British 48, 103, 119, 134, 188

Great Patriotic War 24, 25, 33, 214, 217

Great War, see First World War

Greece, Greek 45, 79, 86, 87, 103, 110

Gross Rosen 65, 199. See also Rogoźnica

Gross, Jan T. 226

Grubecki, Jan 92

Grunwald 25, 87, 91, 193

Guderian, Heinz 208

Gulag 44, 46, 55, 101, 109, 136, 224

Gusen (Mauthausen-Gusen) 109

Gust, Krystyna 107

Gwardia Ludowa, see People's Guard

Halbwachs, Maurice 20

Halecki, Oskar 225

Hallstein, Walter 169

Hamburg 94

Hatch, Mary Jo 37

Heda, Antoni 148

Herf, Jeffrey 220

Himmler, Heinrich 108

Hiroshima 103, 170

Hitler, Adolf 26, 32, 48, 85, 96, 108, 165, 168, 204, 207, 219, 222

Hitlerism, Hitlerite 19, 26, 87, 94-96, 99, 101, $103,108,110,112,114,115,164,167$, 168, 173, 174, 197, 199, 204-09, 211

Hoffman, Paweł 204

Holocaust 32, 45, 49, 64, 104, 199, 204, 205 , 209, 218, 220-24, 226

Hołuj, Tadeusz 141, 143, 144, 146, 147, 170, 171,194

Home Army (AK) 14, 39-41, 43-45, 48, 55, $58,60,62,63,68-70,77,79,87,93$, 113-16, 119, 121, 122, 136-38, 140-44, 146-51, 155, 156, 158-61, 167, 171-75, $182,184,186-93,211,218,223$

Hrubieszów 149, 151, 153, 155

Huener, Jonathan 104

Hungary, Hungarian 86, 106, 111, 153, 218, $219,225,227$

IAC, see International Auschwitz Committee 
Institute of National Remembrance (IPN) 39, Kielce 113, 114, 137, 148, 188 46, 224, 225, 226

Kirchmayer, Jerzy $68,119,121,141,146$

Instytut Pamięci Narodowej, see Institute of National Remembrance

Kiryluk, Stanisław 119, 121, 123, 132

Kliszko, Zenon 187

Insurgent(s) 30, 48, 59, 62, 70, 77, 82, 161, 172 Kluczbork 74

International Auschwitz Committee (IAC) Kochanowski, Jerzy 16 $106,134,171$

Kokoszyn, Aleksander 186

International Federation of Former Political Prisoners (FIAPP) 78, 79, 86, 87, 89, $100,101,104$

Korczyński, Grzegorz 54, 55, 185

Kościuszko, Tadeusz 52, 111

Koszalin 165

International Federation of Resistance Fighters (FIR) 32, 100-02, 106, 134, 139, 141, $169,170,217$

IPN, see Institute of National Remembrance Israel(i) 104, 171, 196, 202, 203, 206-09

Italy 29,86

Izydorczyk, Jan 77, 173

Jabłonowski, Marek 28

Jabłoński, Henryk 179

Jachymek, Zenon 151

Jadów 203

Jakubowska, Wanda 87

Janic, Marian 185, 190

Janów Lubelski 151, 152

Jaruzelski, Wojciech 211

Jaszczukowa, Maria 141

Jaworski, Tadeusz 195

Jeleński, Konstanty A. 201

Jena 17

Kowalski, Edward 100, 101, 141

Kozek, Wiesława 17

Kraków 29, 77, 108, 140, 201

Krasicki, Janek 165

Kraśnik 151, 153, 155

Krasnystaw 132, 156

Księżarczyk, Franciszek 132, 140, 141

Kukiełka, Bolesław 40

Kula, Marcin 16, 117

Kuperman, Marek 202, 203

Kur, Tadeusz 204

Kuryłowicz, Adam 140, 143, 148, 169

Kuszko, Eugeniusz 112, 166

Kutno 166, 174

Kwaśniewski, Stefan 151

Kwiatkowski, Jan 154

Lagrou, Pieter 31, 64, 101, 220

Lampe, Alfred 111, 211

Lane, Christel 24

Jew(s), Jewish 31, 34, 46, 49, 54, 59, 63-65, $70,71,75,103,107,114-17,119,140$, $151,155,160,170,171,184,195,196$, 198-209, 219-24, 226

Jodłowski, Jerzy 93

Langbein, Hermann 106

Law, see Veteran law in Poland

Lechowicz, Włodzimierz 173, 211

Lemko(s) 71

Lenartowicz, Stanisław 193

Joliot-Curie, Frédéric 92

Jóźwiak, Franciszek 58, 87, 93-95, 99, 104, $122,137,139,140$

Judt, Tony 224

Lenino 47, 54, 55, 112, 193

Leroy, André 101

Lewińska, Pelagia 78

Lim, Jie-Hyun 227

Lithuania(n) 25, 71, 193

Karge, Heike 33, 34

Katowice 142, 172

Łódź 60, 137

London 44, 45, 53, 94, 98, 114, 139, 174

Katyn 47, 136

Łopiennik 132

Lubań 74 ance Fighters

Khrushchev, Nikita 135, 136, 139, 157, 217, Lubartów 149, 155 218 
Lublin $12,38,40,54,113,120,121,123,124$, $126,132,137,140,141,149,150-52$, 155-57, 166, 174, 191, 192, 193, 202, 203

Luckmann, Thomas 38

Łuczak, Czesław 49

Łuków 126

Lviv see Lwów

Lwów (Lviv) 157

Lwówek Śląski 74

Mach, Wilhelm 194

Machcewicz, Paweł 135

Main Commission for Patriot Priests 120

Main Commission for Research into German/ Hiterites Crimes in Poland 46, 179, 204, 205

Majdanek 38, 65, 81, 96, 102, 108, 166, 174, 199

Manhès, Frédéric-Henry 87

Mann, Michael 45

Marcuse, Harold 22

Mark, James 221

Matuszewski, Stanisław 82

Matysiak, Henryk 81, 96, 103, 120, 141, 142, $162,165,173,189,211$

Mauthausen 102, 106, 107, 109, 141

Mazurek, Małgorzata 16

Mazurkiewicz, Jan 63, 68-70, 143, 146, 147, 211

Mazurkiewicz, Stanisław 63

Moczar, Mieczysław 19, 39, 137, 141, 143, $148,157,174,179,181,183-87,189$, 190, 192, 193, 202, 203, 208, 209, 211

Modliborzyce 152

Moldova 225

Molotov-Ribbentrop Pact (1939) 44, 227

Monte Cassino 165

Mościcki, Ignacy 108

Moscow 110, 169, 215, 217

Munk, Andrzej 193, 195

Mussolini, Benito 110

Namiotkiewicz, Walery 137, 185

Narbutt, Ignacy 142

Narodowe Siły Zbrojne, see National Armed Forces
National Armed Forces (NSZ) 48, 70, 114, $148,150,151,152,156,157,159,160$, 199,223

National Association of Former Resistance Fighters 32

National Association of Volunteer Resistance Fighters 32

National Confederation of Political Prisoners 101

National Confederation of Volunteer Resistance Fighters 32

National Federation of Deported and Imprisoned Resistance Fighters and Patriots 31

National Federation of Deportees and Internees of the Resistance Movement 31

National Union of Former Political Prisoners 101

Nationale Vereniging der Ex-Politieke Gevangenen, see National Union of Former Political Prisoners

Nationalism, nationalist 26, 27, 30, 60, 64, $82,90,98,99,119,137,157,158,160$, 161, 174, 176, 184, 187, 201, 202, 211, 224,227

Nazarewicz, Ryszard 48, 117, 179

Nazi Germany, see Third Reich

Nazism, Nazi(s) 15, 26, 31, 46, 48, 59, 62, 65, $95,96,101,108,109,120,136-38,167$, 168, 173, 204, 208, 209, 216, 219, 222, 224-26

Neumann-Thein, Philipp 34

New York 16

Newiak, Sylwester 142

Niećko, Józef 92

Niedzielski, Mieczysław 186

Nora, Pierre 20, 21

Normand, Marie 107

Norway, Norwegian 159, 218

Nowak, Barbara A. 36

Nowak, Zenon 156

Nowak-Jeziorański, Jan 185

Nowotko, Marceli 102, 165

NSZ, see National Armed Forces

Ochab, Edward 125

October Revolution 24, 26, 96 
Oder-Neisse border 44, 72, 73, 167, 197, 207, 219

Olsen, Arthur 185

Olszewski, Jan 137

Olsztyn 67

Opole 74, 161

Palestine 49, 71, 104

Parczew 115, 117, 154, 155

Partisan(s) 15, 17, 19, 38-40, 44, 48, 49, 51, 52, 54-56, 58, 62, 68, 70, 77, 82, 94, 99, $113-18,120,137,141,143,146,149$, $151-53,157,159,161,165,166,174$, $176,183,185,186,188,190,192,193$, 195, 214-16

Partisans' movement in PZPR 157, 183-87, 193-95

Passini, Józef 93, 121, 123

Peasants' Battalions (BCh) 40, 48, 55, 58, $114,121,150,151,155,161,167,174$, 183,192

People's Army (AL) 40, 48, 54, 55, 58, 113 $17,121,137,140-43,147,149,151,152$, 159, 161, 165-67, 172, 174, 184, 185, 192

People's Guard (GL) 48, 52, 113-17, 147, 165-67

Petelski, Czesław 195

Pietrzak, Tadeusz 185

Pilichowski, Czesław 204

Piłsudski, Józef 30, 78

Piórkowski, Jerzy 137

Pióro, Tadeusz 140

PKWN, see Polish Committee for National Liberation

Płaszów 144

Polish Armed Forces 52, 66, 72, 76, 151, 166, 167, 172, 173, 178, 179, 191

Polish Armed Forces in the East 15, 47, 55, $60,71,75,98,110-12,120,165,166$, 174, 188, 190, 191-93, 224

Polish Armed Forces in the West 14, 47, 119, $137,165,166,174,183,190-92$

Polish Committee for National Liberation (PKWN) 38, 51, 52, 53, 90

Polish Red Cross 61-63, 179
Polish Secret State, see Polish Underground State

Polish Underground State 45, 48, 93

Polish Union of Former Political Prisoners (PZbWP) 58-60, 65, 67, 78, 79, 81, 104, 146

Polish-Soviet War (1919-21) 28, 51

Polski Komitet Wyzwolenia Narodowego, see Polish Committee for National Liberation

Polskie Państwo Podziemne, see Polish Underground State

Powązki (military cemetery in Warsaw) 62, 63, 69, 139

PoWs, see Prisoners of war

Poznań 135, 172, 174, 199

Prenzlau 141

Priest(s) 79, 104, 120

Prisoner(s) 13, 14, 31, 34, 38, 40, 47, 49, 51, $53-55,59,61,65-68,71,77-79,81-83$, $86,87,89,93,94,100,101,106-11,117$, $118,120,128,135-37,139,141,143$, $144,146,158,160,161,166,169-72$, 177, 178, 180, 183, 190-92, 195, 211, 216-19, 222

Prisoners of war $32,40,47,48,116,141,182$, 218

Prost, Antoine 30

Prussia(n) 28, 51, 64, 89, 174

Puławy 126

Putrament, Jerzy 110, 158

PZbWP, see Polish Union of Former Political Prisoners

Quisling, Vidkun 159, 160, 218

Rada Ochrony Pamięci Walk i Męczeństwa, see Council for the Protection of Struggle and Martyrdom Sites

Radogoszcz 174

Radom 150

Rakowski, Mieczysław F. 168, 183, 184, 185, 186

Rapacki, Adam 134

Ravensbrück 102, 105, 106, 130, 131, 141, 170

Red Army 15, 44, 47, 48, 52, 55, 73, 86, 87, 90, 96, 109, 110-13, 151, 165, 172, 193, $215,218,219$ 
Red Cross, see Polish Red Cross

Reinefarth, Heinz 168

Rév, István 16

Rola-Żymierski, Michał 55

Romania(n) 86, 196, 218, 219, 225

Rommel, Erwin 208

Rosenberg, Ethel 109

Rousset, David 101

Rousso, Henry 26, 27

Rózga, Wacław 93, 128

Ruchniewicz, Krzysztof 16

Rusinek, Kazimierz 141, 147, 148, 150, 158 $60,173,174,179,207,211$

Russia(n) 32, 51, 53, 64, 109, 115, 156, 214, 215, 223, 227. See also Soviet Union

Rzepecki, Jan 139, 141

Sachsenhausen 102, 106

Sanacja 78, 81, 87, 108, 110, 114, 119, 120, 149, 191

Savez Boraca u Narodnooslobodilačkom ratu u Jugoslaviji, see Union of Fighters in the War of National Liberation in Yugoslavia

Sawicka, Hanka 107, 165

SBNORJ, see Union of Fighters in the War of National Liberation in Yugoslavia

Sęk-Małecki, Józef 55, 185

Serhy, Yekelchyk 215

Siberia(n) 30, 53, 109, 223

Sikorski, Władysław 188

Sikorski-Mayski agreement (1941) 47

Site(s) of memory 20-22, 99-117, 143, 197, 227

Slovakia 218, 227

Słowacki, Juliusz 160

Snyder, Timothy 32

Sobibór 38, 65, 107, 199

Soldier(s) 14, 15, 19, 22, 24, 27-32, 38, 40, $44,45,47,48,51-53,55-58,60,62,63$, $65,66,68-77,79,82,86,87,89,90,94$, $95,110-17,120-22,134,136,137,139$, $140,145,146,151,155,159,161,165$, $166,171,172,174-76,181-83,187,188$, 190-92, 194, 209, 214-16, 218, 222

Soltysiak, Marian 148, 188
Sovetskii Komitet Veteranov Voiny, see Soviet Committee of War Veterans

Soviet Committee of War Veterans 33, 216

Soviet Union, Soviet 24-26, 33, 36, 37, 43, $44,46-49,53-55,62,65,71,73,85-87$, 90, 92, 93, 96, 98, 101, 102, 107, 111, $112,115,116,119,133,136-38,140$, $149,152,156,160,167,176,211,214$ $18,220,223,225$

Spain, Spanish 40, 52, 54, 79, 86, 97, 100, 103, 120, 134, 141, 180

Spanish Civil War (1936-39) 54, 100, 180

Spychalski, Marian 119

Srebrzyński, Jan 195

Stalin, Józef 32, 85, 92, 98, 111, 211, 215, $217,218,222$

Stalingrad 96, 112, 113

Stalinism, Stalinist 14, 15, 26, 37, 69, 104, $113,118,119,133-36,141,143,144$, $147,150,153,160-62,166-68,176-79$, 182-84, 189, 208, 211, 215, 227

Starewicz, Artur 184

Stasiak, Leon 179

Staszewski, Stefan 204

Stola, Dariusz 17, 33, 201

Stutthof (Sztutowo) 65, 141, 144, 199

Świerczewski, Karol 87, 111

Szacka, Barbara 16

Szálasi, Ferenc 218

Szaniawski, Jan 142, 161

Szczecin 157

Szlachcic, Franciszek 185

Szmaglewska, Seweryna 177

Szuba, Antoni 132

Szurek, Aleksander 100

Szyr, Eugeniusz 92

Tarnawka 156

Tatar, Władysław 119

Tetmajer, Alina 66

Thälmann, Ernst 102

Thaw, see 1956

Third Reich 93, 98, 103, 105, 108, 168, 169, 206, 209

Tiso, Jozef 218 
Tito, Josip 52, 110, 216

Tomaszów Lubelski 126, 132, 151, 152, 155

Totalitarianism, totalitarian $34,35,37,79$, 161,226

Traba, Robert 46

Treblinka 54, 65, 96, 107, 199

Troebst, Stefan 224

Truman, Harry S. 85

Ukraine, Ukrainian(s) 24, 32, 43, 45, 71, 75, 113, 215, 226, 227

Ukrainian Insurgent Army (UPA) 71, 151, 175

Ukrayins 'ka Povstans'ka Armiya, see Ukrainian Insurgent Army

Union de la Résistance pour une Europe Unie, see Union of Resistance Fighters for a United Europe

Union Française des Anciéns Combattants, see French Union of Former Combatants

Union of Armed Struggle (ZWZ) 43, 115

Union of Dąbrowski Soldiers 59, 77

Union of Fighters in the War of National Liberation in Yugoslavia (SBNORJ) 34, 162

Union of Jewish Partisans 70

Union of Military Settlers in the Recovered Territories (ZOW) 58, 75, 79

Union of Participants in the Fight for the Freedom of Spain in 1936-39, see Union of Dąbrowski Soldiers

Union of Participants of the Armed Struggle for Independence and Democracy (ZUWZoNiD) 54

Union of Polish Patriots 98, 111

Union of Resistance Fighters for a United Europe 32

Union of Veterans of the Revolutionary Struggles of 1905-18 60, 77

Union of Veterans of the Silesian Uprisings (ZWPŚ) 59, 70, 71

Union of Wielkopolska Insurgents of 1918-19 (ZPW) 59, 82

United Kingdom 188, 207. See also Great Britain

United Nations (UN) 66, 95, 105, 134, 170
United States of America, American 24, 85, 90, 94, 95, 101-03, 107, 109, 110, 119, 185, 187, 206-08, 214, 220

UPA, see Ukrainian Insurgent Army

USA, see United States of America

USSR, see Soviet Union

Vatican 89, 105

Venken, Machteld 17

Vereinigung der Verfolgten des Naziregimes, see Association of Persons Persecuted by the Nazi Regime

Veteran law in Poland 14, 27, 46, 49, 51-54, $67,144,145,169,213,217$

Vienna 17, 95, 100, 106

Vilnius, see Wilno 157

Volhynia 149

Vorkuta 102

VVN, see Association of Persons Persecuted by the Nazi Regime

Wajda, Andrzej 193

Wajsbrot, Mojżesz 202

Wajskop, Grzegorz 202

Walichnowski, Tadeusz 206, 207

Warneńska, Monika 108

Warsaw 16, 38, 40, 44, 50, 55, 60, 61, 62-64, 69, 78, 86-88, 91, 100, 103, 104, 106, $107,112,113,116,117,120-123,134$, $135,139,142,147,148,151,161,166$, $168,172,173,177,179,183,184,186-$ 89, 191-93, 203, 205, 211

Warsaw Ghetto 64, 117, 199, 200

Warsaw Ghetto Uprising 116, 199, 205

Warsaw Uprising 38, 48, 62, 63, 68, 69, 87, $116,119,136,138,139,161,168,174$, 187,225

Washington 94

Wasilewska, Wanda 111, 211

Wehrmacht 71, 106, 145, 208, 222

Weimar Republic 29

Weiner, Amir 24, 25

Welker, Jerzy 161

Werfel, Roman 158

Wertsch, James V. 214

West Germany, see Federal Republic of Germany 
Westerplatte 166, 174

Wilno (Vilnius) 157

WiN, see Freedom and Independence

Winter, Jay 21

Witek, Teofil 109

World Federation of Former Combatants (FMAC) 139, 217

Wóycicka, Zofia 16, 64

Wroclaw 16, 140, 157

Wroński, Stanisław 183, 184

Wyderkowski, Jan 149

Yugoslavia(n) 33, 45, 52, 86, 103, 110, 162, $189,215,216,218,221$

Zaklików 152

Zamość 48, 151, 197

Zaremba, Marcin 16

Żaryn, Jan 104, 105

Zarzycki, Janusz 11, 137, 140, 147, 156, 159, $171,173,174,179,183,184,187,189$, $192,193,199,200$

Zdunek, Władysław 141, 149, 155, 156, 157

Zernack, Klaus 225

Zgorzelec 44, 74

Ziętek Jerzy 70, 141

ZOW, see Union of Military Settlers in the Recovered Territories
ZPW, see Union of Wielkopolska Insurgents of 1918-19

Zrzeszenie Wolność i Niezawistość, see Freedom and Independence

ZUWZoNiD, see Union of Participants of the Armed Struggle for Independence and Democracy

Związek Dąbrowszczaków, see Union of Dąbrowski Soldiers

Związek Osadników Wojskowych na Ziemiach Odzyskanych, see Union of Military Settlers in the Recovered Territories

Związek Patriotów Polskich, see Union of Polish Patriots

Związek Uczestników Walki Zbrojnej o Niepodległość i Demokrację, see Union of Participants of the Armed Struggle for Independence and Democracy

Zwiazek Walki Zbrojnej, see Union of Armed Struggle

Związek Weteranów Powstań Ślaskich, see Union of Veterans of the Silesian Uprisings

ZWPŚ, see Union of Veterans of the Silesian Uprisings

ZWZ, see Union of Armed Struggle 


\section{Warsaw Studies in Contemporary History}

Edited by Dariusz Stola / Machteld Venken

Vol. 1 Maciej Górny: The Nation Should Come First. Marxism and Historiography in East Central Europe. 2013.

Vol. 2 Zofia Wóycicka: Arrested Mourning. Memory of the Nazi Camps in Poland, 1944-1950. 2013.

Vol. 3 Anna Witeska-Młynarczyk: Evoking Polish Memory. State, Self and the Communist Past in Transition. 2014.

\section{Studies in Contemporary History}

Vol. 4 Joanna Wawrzyniak: Veterans, Victims, and Memory. The Politics of the Second World War in Communist Poland. Translated by Simon Lewis. 2015.

www.peterlang.com 